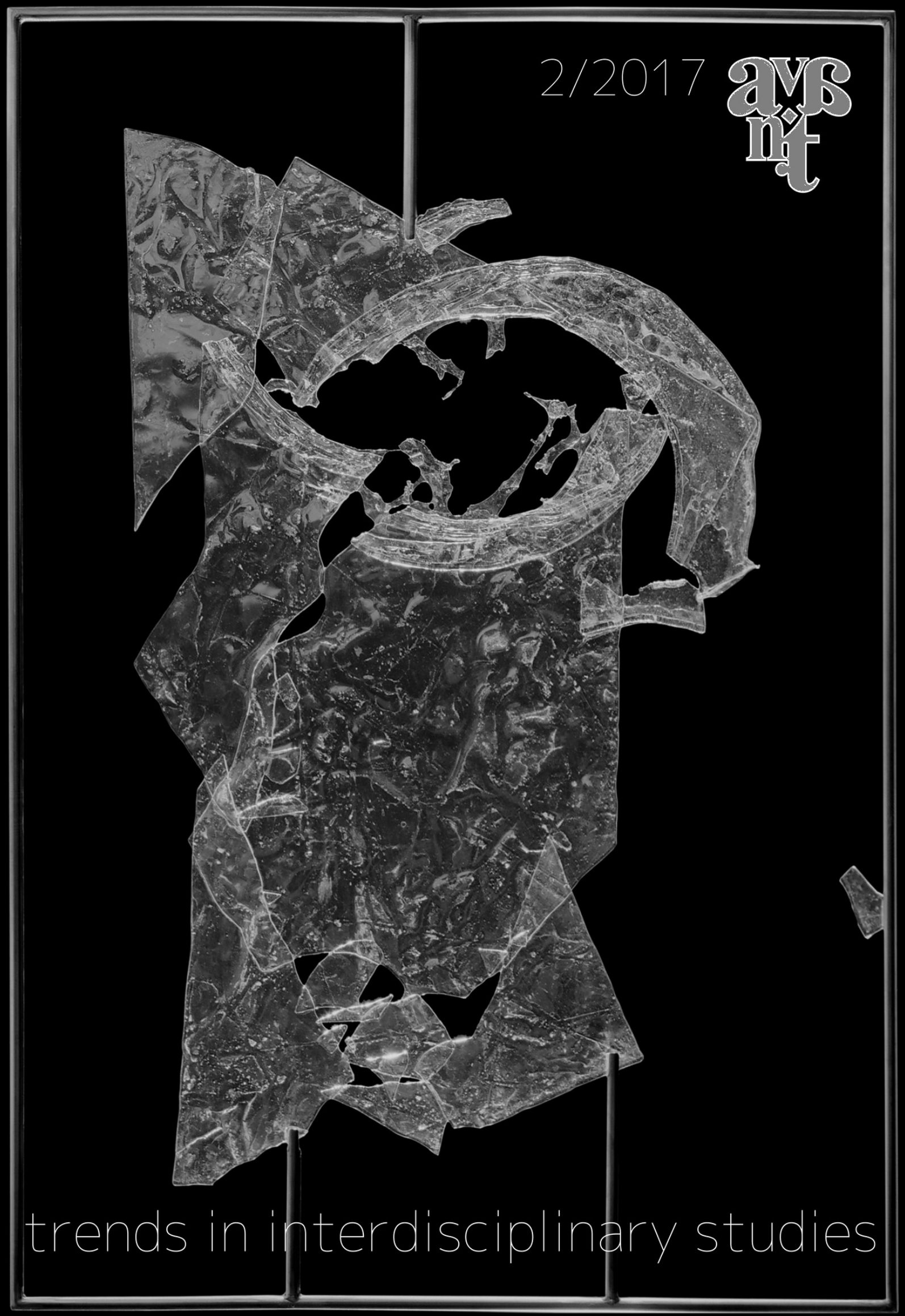



TRENDS IN INTERDISCIPLINARY STUDIES

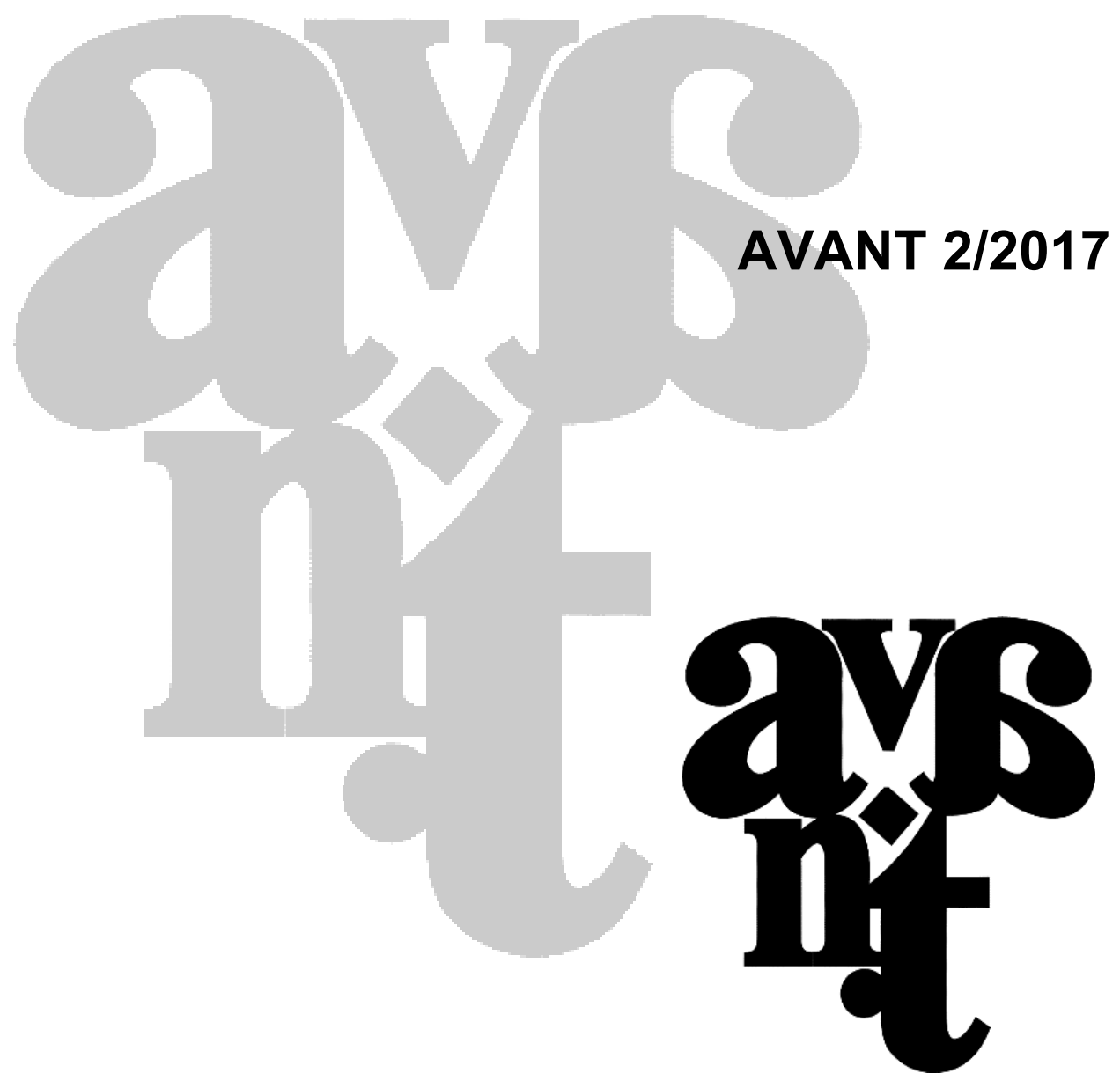

Haunted Cultures / Haunting Cultures

\section{EDITORS}

Edyta Lorek-Jezińska \& Katarzyna Więckowska

TORUŃ 2017 
ISSN: 2082-6710

AVANT. The Journal of the Philosophical-Interdisciplinary Vanguard

Trends in Interdisciplinary Studies

Vol. VIII, 2/2017,

Haunted Cultures / Haunting Cultures

The texts are licensed under: CC BY-NC-ND 3.0.

This online version of the journal is a referential version.

The cover design by Janusz Matysiak. Graphics on the cover by Anna Kola.

\author{
Address of the Editorial Office: \\ ul. Stawki 3/20, 00-193, Warsaw, Poland \\ www.avant.edu.pl/en avant@avant.edu.pl \\ Publisher: Centre for Philosophical Research \\ ul. Stawki 3/20, 00-193, Warsaw, Poland \\ www.obf.edu.pl
}

The Journal has been registered in District Court in Warsaw, under number: PR 17724.

AVANT is listed in Scopus (Elsevier), Emerging Sources Citation Index (Web of Science Core Collection), The European Reference Index for the Humanities and the Social Sciences (ERIH PLUS), The Directory of Open Access Journals (DOAJ),

Index Copernicus Journals Master List, Central and Eastern European Online Library (CEEOL), The Central European Journal Of Social Sciences And Humanities (CEJSH), EBSCO Publishing, PhilPapers, Polish Ministry of Science and Higher Education List of

Scored Journals, Academic Journals Database, The ZDB database, EZB Library, WZB Library, HBZ Library, JURN Directory, WorldCat Catalog, NEOS Catalogue, BazHum: Virtual Library of Science, Advanced Science Index, ARIANTA Register, Polski Indeks Filozoficzny, and others. 


\section{ADVISORY BOARD}

Chairman: Włodzisław Duch (Nicolaus Copernicus University; Nanyang Technological University); Krzysztof Abriszewski (Nicolaus Copernicus University); Ewa Bińczyk (Nicolaus Copernicus University); Maciej Błaszak (Adam Mickiewicz University); Tadeusz Ciecierski (University of Warsaw); Fred Cummins (University College Dublin); Tom Froese (University of Tokyo); Marek Kasperski (ThinkLab); Joel Krueger (University of Copenhagen); Dariusz Lukasiewicz (Kazimierz Wielki University); Jacek Malinowski (Polish Academy of Sciences; Nicolaus Copernicus University); Sofia Miguens (University of Porto); Marcin Milkowski (Polish Academy of Sciences); JeanLuc Petit (Université de Strasbourg; Collège de France); Robert Poczobut (University of Bialystok); Piotr Przybysz (Adam Mickiewicz University); Eleanor Rosch (University of California); Bartlomiej Świątczak (University of Science and Technology of China).

\section{PEER REVIEW BOARD}

Glenn Carruthers (Macquarie University); Igor Dolgov (New Mexico State University); Tatiana Chernigovskaya (St. Petersburg State University); Kathleen Coessens (Vrije Universiteit Brussel); Maciej Dombrowski (University of Wrocław); Judith Enriquez (University of North Texas); Katalin Farkas (Central European University); Rafal Gruszczyński (Nicolaus Copernicus University); Tomasz Jarmużek (Nicolaus Copernicus University); Andrzej Kapusta (Maria Curie-Skłodowska University); Piotr Konderak (Maria Curie-Skłodowska University); Marek McGann (University of Limerick); Kajetan Młynarski (Jagiellonian University); Georg Northoff (University of Ottawa); Andrzej W. Nowak (Adam Mickiewicz University); Peter S. Petralia (Manchester Metropolitan University); Witold Plotka (University of Gdańsk); John Sutton (Macquarie University).

Additionally, AVANT engages occasional peer reviewers. 


\section{EDITORIAL BOARD}

Thematic Editors: Lukasz Afeltowicz (Nicolaus Copernicus University; Sociology); Aleksandra Derra (Nicolaus Copernicus University; Philosophy of Language \& Philosophy of Science); Pawel Gladziejewski (Nicolaus Copernicus University; Social Cognitive Science); Witold Hensel (University of Bialystok; Theory of Knowledge); Tomasz Komendziński (Nicolaus Copernicus University; Interdisciplinary Studies, Enactivism \& Neurophenomenology); Victor Loughlin (University of Antwerp; Philosophy of Mind \& Cognitive Science); Georg Theiner (Villanova University; Philosophy of Mind \& Cognitive Science)

Language Editors: Mike Timberlake

Technical Editor: Filip Stawski

Administrative Editor: Maria Onyszkiewicz

Editorial Secretary: Marcin Lysiak

Managing Editor: Przemysław Nowakowski

Executive Editor: Witold Wachowski

Haunted Cultures / Haunting Cultures

Editors: Edyta Lorek-Jezińska \& Katarzyna Więckowska

This publication has been financed by the Ministry of Science and Higher Education from the funds for the dissemination of research (DUN) within the framework of publishing activity, contract no. 606/P-DUN/2016, period of implementation: the years 2016-17.

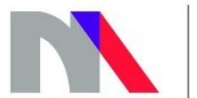

Ministry of Science and Higher Education

Republic of Poland 


\section{Table of Contents}

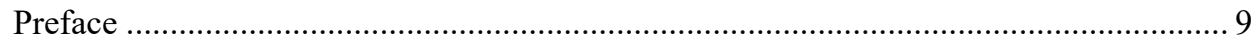

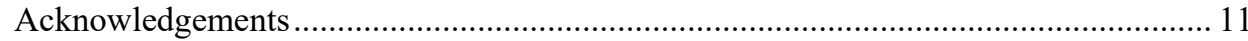

\section{INTRODUCTION}

Edyta Lorek-Jezińska \& Katarzyna Więckowska:

Applied Hauntologies: Spectral Crossings and Interdisciplinary Deconstructions 15

\section{ARTICLES}

\section{Part One: Ghost Writing}

Tadeusz Rachwal:

Spectres of Paper: Writing, Digitization, and the End(s) of the Book 31

Michal Krzykawski:

J'accepte: Jacques Derrida's Cryptic Love by Unsealed Writing. 39

Juan Evaristo Valls Boix:

"The Art of Writing Posthumous Papers": Kierkegaard and the Spectral Audience 51

\section{Part Two: Un-burying Ghosts}

\section{Arthur Redding:}

Burial Grounds and Dead Lovers:

Places of Interment in the Gothic Modernism of the American South.

\section{Zuzanna Szatanik:}

On the Threshold: Haunting Transgressions in Gaétan Soucy's

The Little Girl Who Was Too Fond of Matches

\section{Anna Branach-Kallas:}

Crypts, Phantoms, and Cultural Trauma:

A Hauntological Approach to Recent British First World War Fiction

Aleksandra Kędzierska:

Dermot Bolger's Ghosting the War 101 


\section{Part Three: Spectral Media}

Anne Keithline \& Jacek Mydla:

The Gaze of the Spectral Setting in the 1968 BBC Adaptation of

M. R. James's “Oh, Whistle, and I'll Come to You, My Lad”

Edyta Lorek-Jezińska:

Hauntology, Performance and Remix: Paradise // Now?

\section{Anna Kisiel:}

Spectral-Fragile-(Un)homely:

The Haunting Presence of Francesca Woodman in the House and Space ${ }^{2}$ Series 145

Tymon Adamczewski:

Hauntology of Responsibility: Tom Stoppard's Darkside 157

\section{Part Four: Ghostly Legacies}

Barbara Klonowska:

Haunting across the Class Divide: Sarah Waters's Affinity and The Little Stranger..... 171

Katarzyna Więckowska:

Spectral Economies in Graham Swift's Mothering Sunday: A Romance.

Agnieszka Pantuchowicz:

The Haunting Presence of the Feminine: Virginia Woolf in the Streets of London

Pawel Pyrka:

Haunting Poe's Maze: Investigative Obsessions in the Weird Fictions of Stefan Grabiński and H. P. Lovecraft.

\section{REVIEWS}

\section{Miroslawa Buchholtz:}

Of Maps and Monsters: A Discussion of Being (Non)Human, or on the Topography of "Monsters" Medieval and Modern by Liliana Sikorska ....... 215

Edyta Lorek-Jezińska \& Katarzyna Więckowska:

Spectral Uncertainities: A Review of Precarity and Loss:

On Certain and Uncertain Properties of Life and Work by Tadeusz Rachwał

Marek Jeziński:

A Book Review of Duchologia polska. Rzeczy i ludzie w latach transformacji by Olga Drenda.

THE ARTIST OF THE ISSUE

Anna Kola: About the Artist

Contributors to this Issue 


\section{Preface}

Dear Readers,

We are pleased to present this year's second issue of AVANT. Its leading theme is hauntology, a theoretical perspective defined by Jacques Derrida and applied in numerous interand transdisciplinary studies. The issue includes articles on various instances of haunting and spectrality, grouped into four parts, titled "Ghost writings," "Un-burying ghosts," "Spectral media," and "Ghostly legacies." The issue features studies by Tadeusz Rachwał, Michał Krzykawski, Juan Evaristo Valls Boix, Arthur Redding, Zuzanna Szatanik, Anna Branach-Kallas, Aleksandra Kędzierska, Anne Keithline and Jacek Mydla, Edyta LorekJezińska, Anna Kisiel, Tymon Adamczewski, Barbara Klonowska, Katarzyna Więckowska, Agnieszka Pantuchowicz, and Paweł Pyrka, followed by reviews of books related to spectral practices by Mirosława Buchholtz, Katarzyna Więckowska and Edyta LorekJezińska, and Marek Jeziński. The issue presents the work of Anna Kola, a photographer, graphic designer, and glass artist.

Editors

Toruń, Autumn 2017 



\section{ACKNOWLEDGEMENTS}

We would like to thank all researchers whose work is published in this volume for their contribution to the study of the discourses of ghosts in Haunted Cultures / Haunting Cultures. We are also very grateful to AVANT for agreeing to host this spectral project, in particular to Witold Wachowski and Marcin Łysiak, whose advice and competence helped us bring it to completion. Many thanks go to Anna Kola, whose artwork perfectly captures this issue's spectral fascinations.

Edyta Lorek-Jezińska and Katarzyna Więckowska 



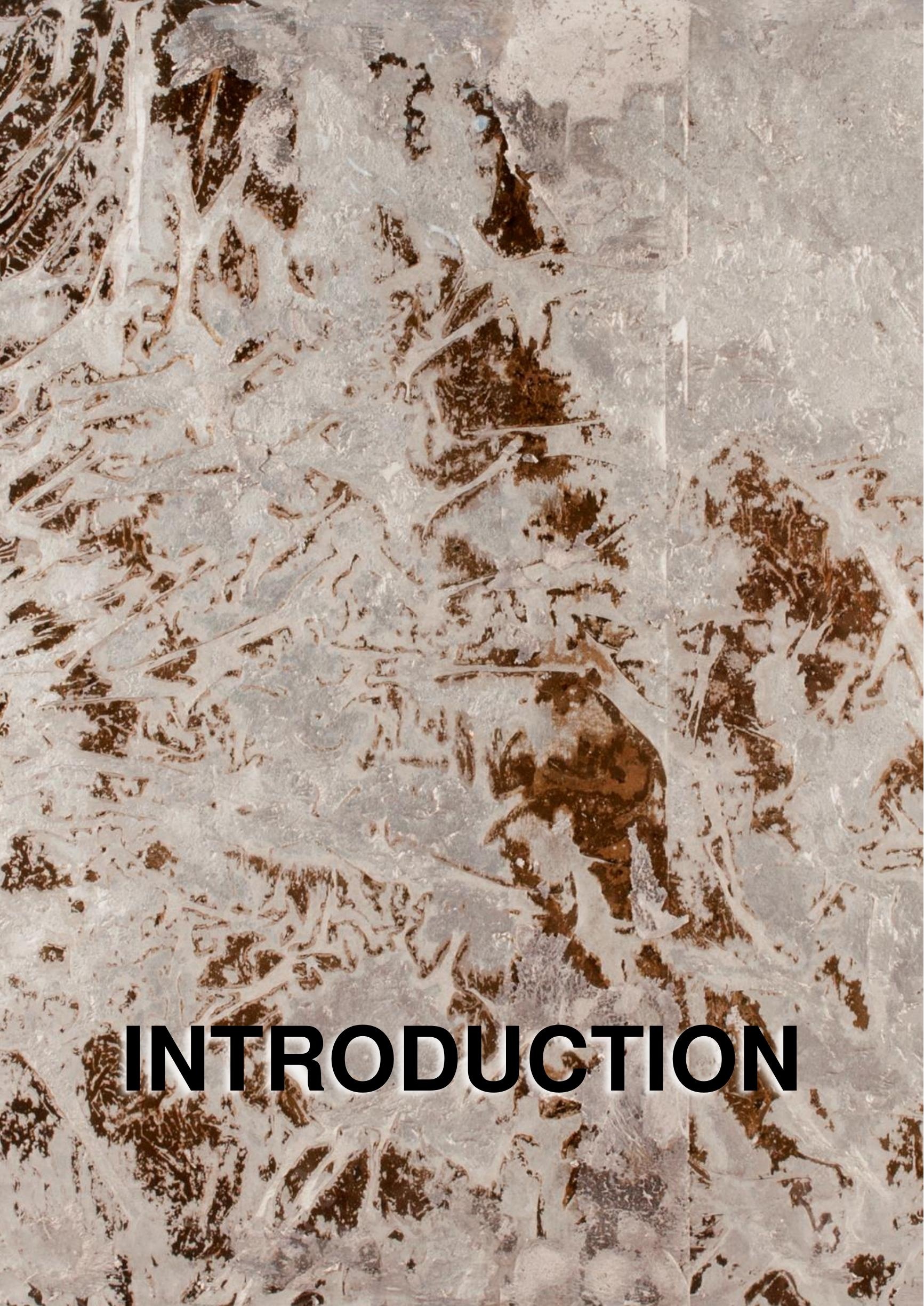


Anna Kola, $\boldsymbol{K}-\boldsymbol{I}$, steel, fused glass, aluminum foil, $50 \times 50 \mathrm{~cm}, 2009$ (fragment) 


\title{
Applied Hauntologies: Spectral Crossings and Interdisciplinary Deconstructions
}

\author{
Edyta Lorek-Jezińska \\ Nicolaus Copernicus University in Toruń \\ lorek@umk.pl \\ rsity in Toruń
}

\author{
Katarzyna Więckowska \\ Nicolaus Copernicus University in Toruń \\ klew@umk.pl
}

This issue of AVANT is dedicated to hauntology, an approach originally defined by Jacques Derrida as a "logic of haunting" that is "larger and more powerful than an ontology or a thinking of Being," and that "harbor[s] within itself, but like circumscribed places or particular effects, eschatology and teleology themselves" (Derrida, 1994, p. 10). At a most general level, hauntology is a study of spectrality and spectres - that is, entities and processes that exceed any definite categorization; accordingly, it inevitably questions the established notions of being, thereby transforming the status of the objects and subjects of knowledge, and contesting the possibility of objectivity. The very idea of spectres - positioned as they are between worlds and times-disrupts the conventional means of measuring time and space, as well as all kinds of dichotomous conceptualizations, including "the sharp distinction between the real and the unreal, the actual and the inactual, the living and the non-living, being and non-being" (Derrida, 1994, p. 11). Significantly for the articles collected in this issue, the figure of the spectre questions the divisions between texts, and the separation between the individual and the social/communal, thus palpably demonstrating the impossibility of examining any concept or text independently of others. Accordingly, instead of looking for certainties, the scholar of spectres looks for sites of crossings, borrowings, and contaminations, re-discovering traces of other times, places, and beings in the seemingly solid here and now, and producing somewhat melancholic accounts of a culture that is both already haunted and potentially haunting.

The publication of Derrida's Spectres de Marx in 1993 - itself an interdisciplinary study embracing philosophy and its various sub-disciplines, ontology and ethics in particular, political science, history, literary theory and criticism, and psychoanalysis - brought about a number of other interdisciplinary publications, uses and appropriations, reaching beyond the scope of the original book and crossing into the fields already partly occupied by the 
studies of the Gothic, the uncanny and trauma. ${ }^{1}$ Hauntology has proved a capacious concept lending itself to surprisingly practical applications in a range of cross-, inter-, multi- and transdisciplinary studies, which could be named "applied hauntology." Applied hauntology can be thought of as embracing the practical uses of the spectral categories and deconstructive approaches in literary and cultural analyses, media studies, new and digital media research, and art criticism, among many other fields. Hauntology and its variations have been deployed to account for a variety of tendencies and phenomena eluding more traditional and systematic approaches, running across disciplines and fields of inquiry. ${ }^{2}$ In this context hauntology calls for a radical reformulation of what constitutes the object of "respectable" knowledge and might be considered, as Colin Davis argues, "a new aspect of, the ethical turn of deconstruction" (2005, p. 373). ${ }^{3}$ Both the ethical and the spectral turns evidence how the concepts located within and in-between ontology, epistemology and ethics feed into the fields of cultural, literary and media studies, and how they bear upon cultural and social practices of remembrance, representation, visibility, and vulnerability. Opening up spaces for re-considering "something lost or barely visible, or seemingly not there" (Gordon, 2004, p. 8), hauntology helps us to understand and define our relation to the past, responsibility for the others, and imaginings of the future.

Hauntology has been used to describe and problematize the indeterminacy and interconnectedness of texts, the presence of memory and traumatic experience in the present time, the identity and legitimacy of various Others and their suppressed representations and haunting absences, and what goes with it - our responsibility for preserving them, the validity and persistence of the past, the demands of the dispossessed, the presence of the uncanny, mourning practices, the uncertainty and non-finality of death, the transformation and redefinition of mediated and technological selves. The studies collected in this issue of AVANT address all of these questions, highlighting various ways in which hauntology can be used to destabilize conventional divisions and established analytical tools, so as to offer a potentially different kind of reading. The articles relate to a variety of texts-literary, cinematic, musical, and visual — and explore an array of questions. They are divided into four parts, whose titles indicate their varying focus. Thus, the articles in "Ghost Writing" highlight the importance of writing both about and with ghosts, while the studies in "Un-burying Ghosts" illustrate the persistence of the traces of the past, especially traumatic, in the present. The texts in "Spectral Media" examine the work of ghosts in various media and technologies, and the articles in "Ghostly Legacies" aim at recovering some of

\footnotetext{
${ }^{1}$ For an overview of the major contributions to the development, see Spectralities Reader: Ghosts and Haunting in Contemporary Cultural Theory edited by M. del Pilar Blanco and E. Peeren (2013).

${ }^{2}$ Geography is a good example of a discipline where the figure of the spectre has been applied by scholars such as John Wylie, Steve Pile, Tim Edensor, and Cheryl McEwan to analyse a variety of phenomena, including everyday practices, colonial experiences, or geographies of visual art. For a discussion of "spectral geographies," see D. Matless (2008).

${ }^{3}$ For a more extensive discussion of knowledge and Derridean hauntology, see Lorek-Jezińska and Więckowska (2017, pp. 8-11).
} 
the Others that have been silenced in (canonical) literary and social spaces. All the articles focus on the examination of specific ghosts from the past and unbury spectres that haunt contemporary culture, thereby binding the present with the past and demonstrating that "everyone reads, acts, writes with his or her ghosts, even when one goes after the ghosts of the other" (Derrida, 1994, p. 139; emphasis in original).

The articles included in "Part One: Ghost Writing" examine various spaces in which and through which haunting may appear, focusing especially on the relations between various kinds of writing, including philosophical and autobiographical ones, and the spectral practices of reading. These investigations uncover numerous series of ghosts and hauntings behind seemingly solid surfaces, thus demonstrating that there never appears merely one spectre, but that always "already there are too many" (Derrida, 1994, p. 138), and that their appearance inevitably complicates the existing divisions, including those between death and life, or reading and writing. The section opens with Tadeusz Rachwał's "Spectres of Paper: Writing, Digitization, and the End(s) of the Book," which traces the spectral existence of paper in the supposedly "paperless" era of digitized media. Stressing its haunting persistence, Rachwał approaches paper as not merely designating the surface or the carrier of writing, but as signifying "the possibility of writing which lives on and survives even now in the epoch of digitization," and speculates what its disappearance or end might mean for a culture which, as he suggests, should be called "a paper culture." In this lucid examination of the interdependencies between paper, analog, and digitized media, Rachwał enquires into the relations between writing, uncertainty, and vulnerability, the potential meanings of ends and beginnings, as well as the making of the human.

In "J'accepte: Jacques Derrida's Cryptic Love by Unsealed Writing," Michał Krzykawski conjures up the ghost of what is conventionally absent or excluded from philosophy, that is, the life and body of the thinker, so as to propose an auto/biographical approach to philosophy that would be also bound with questions of responsibility and ethics. Krzykawski's consideration of Derrida's ghosts focuses on the relation between autobiography and philosophy, or life and writing, and traces the interrelations between the philosopher's conception of love, as conveyed in his "Envois," and such fundamental deconstructive concepts as différance, trace, and dissemination. Arguing for the necessity of a critical way of reading - and thus also of living - the article approaches Derrida's text as a cryptic writing that harbours a secret, or a cipher, whose reading necessitates the use of "the cryptonymic procedure" proposed by Nicolas Abraham and Maria Torok.

“"The Art of Writing Posthumous Papers': Kierkegaard and the Spectral Audience” by Juan Evaristo Valls Boix turns to the Derridean concepts of secret, hospitality, and spectrality to explore the challenge to the metaphysics of reading in Søren Kierkegaard's Either/Or Part I (1843). Valls Boix's analysis of "Shadowgraphs" and "The Unhappiest One" deconstructs the established notions of author, work, and reader and convincingly argues for the use of a distinctively spectral logic of reading/interpreting, where " $[t]$ he text comes from an unknown place, carries an impossible message of sorrow, and flows towards alterity." Accordingly, with the text figured as an empty grave and the reader as a 
figure of alterity, the search for the meaning of a text becomes indeterminate or spectral, so that literature, as Valls Boix argues, must be thought of as "a space of dispossession that demarcates the dissolution of all identity."

Hauntology has been preoccupied with the consequences of memory and incomplete or failed mourning processes. The articles in "Part Two: Un-burying Ghosts," investigate the rituals of burial and remembering the dead, commenting on the persistence of the past, and how "mourning, and its peculiar failures and dissatisfactions," to use Jameson's words, "opens a vulnerable space and entry-point through which ghosts might make their appearance" (Jameson, 2008, p. 43). Haunting and the figure of the ghost embody both the individual process and the social and cultural response to the past trauma and unfinished burials, in which mourning develops a visible spatial dimension of travel, pilgrimage, introspection. While the first two articles in this part reconsider the gothic tradition, of the American South and Canadian literature respectively, the remaining two examine the persistence of the memory of the First World War in contemporary fiction and drama.

Arthur Redding in his article on "Burial Grounds and Dead Lovers: Places of Interment in the Gothic Modernism of the American South" explores the vitality and articulacy of the dead and the dramatic significance of the burial motif in Southern Gothic literature. Drawing upon Roach's argument that modernity as such can be defined "as a new way of handling (and thinking about) the dead" (1996, p. 48), blurring the separations and distinctions between the dead and the living, Redding comments on the novels by American South modernist writers, William Faulkner's As I Lay Dying and Frances Newman's Dead Lovers are Faithful Lovers. The author argues that the "constitutive power of the dead" consists in two major aspects: corporeality of their language and the geographic dimension of the mourning process.

Burial also strongly features in Zuzanna Szatanik's article "On the Threshold: Haunting Transgressions in Gaétan Soucy's The Little Girl Who Was Too Fond of Matches" as a point of departure and a beginning of the pervasively traumatic narrative. Placing the discussion in the context of both English and French Canadian gothic literature, the author embarks on the analysis of Soucy's novel by exploring three aspects of gothic transgressions concerning space, gender and nature. Her analysis of crossing the borders between the inside and the outside, between male and female, and humans and animals leads Szatanik to the conclusion that it is "gothic transgression which becomes the most haunting — and also the most Canadian — presence in Soucy's novel."

In "Crypts, Phantoms, and Cultural Trauma: A Hauntological Approach to Recent British First World War Fiction," Anna Branach-Kallas draws upon Abraham and Torok's concepts of melancholia, melancholic incorporation and transgenerational effect of trauma to comment on the persistence of the First World War as the theme of the turn of the $20^{\text {th }}$ century British fiction. In an illuminating analysis of five novels, the author examines the complex processes of the characters' passage from melancholia to mourning, showing how contemporary loss and bereavement are tied to the past, and how the characters can 
resolve their existential dilemmas only by relating to the First World War. An important aspect of all texts examined by Branach-Kallas is the significance of silence and the unspeakable secret related to the past, posing questions of memory and collective trauma.

In "Dermot Bolger's Ghosting the War," Aleksandra Kędzierska examines Bolger's play published in 2007, Walking the Road, a tribute to Francis Ledwidge, an Irish poet of the First World War. The author persuasively argues that spectrality is an effective means for expressing the aspects of historical memory and forgetting. Silences and spectral ambiguities in particular pose questions about the problematic relation of Ireland to the Great War. The article explores the symbolic significance of ghostly figures, their journey and homelessness as representative of the suppression of memory about Irish soldiers fighting in the First World War in the British army. The author also comments on the role of spectrality in depicting the effects of shell shock, trauma and disintegration of identity.

The articles gathered in the third part of this volume, "Spectral Media," focus on aspects of haunting and spectrality enabled by and resulting from the use of various media and technologies. Three out of four articles presented in this part discuss some form of adaptation from one medium to another. In each case ambiguity, absence or indefinite presence are created by the means of a camera, a digital projection or the radio medium, which, to use Derrida's diction, "capture" and "possess" their object "by spectrality in advance" (2013, p. 39). All articles in this section consider aspects of ontological ambiguity and uncertainty, sometimes implying the uncanny presence or mystery, but in all cases inviting deconstructive questioning of subjectivity, authority, certainty and definition.

In the opening article of this section, "The Gaze of the Spectral Setting in the 1968 BBC Adaptation of M. R. James's 'Oh, Whistle, and I'll Come to You, My Lad',' Anne Keithline and Jacek Mydla examine the spectral effect created by means of the movie camera in the film adaptation of M. R. James's ghost story. The authors focus on the way the film adaptation constructs the spectral point of view nonexistent in the original story. Elaborating on the concepts of the spectral gaze and sympathetic spectreship, the authors conduct an illuminating and detailed analysis of the effects produced by the camera shot and angle and of the ways in which the viewer is manipulated into the position of the haunting setting. The article shows the effectiveness of the technologically produced uncanny and how it can re-create the subjective yet indefinite viewing position of something simultaneously present and absent.

"Hauntology, Performance and Remix: Paradise //Now?" by Edyta Lorek-Jezińska explores the deconstructive strategies employed by the Polish theatre group Komuna Warszawa in their attempt to remix the Living Theatre's performance Paradise Now!. The author examines the process of spectralizing the live performance by means of onstage mediatization and video projections. Suspended between nostalgic re-creation and critical deconstruction, the performance is argued to bring back to life the spectre of political theatre that has lost validity and perhaps also its naïve appeal. The article comments on the difference between live and mediated performance, the aspects of performative memory and generational reception of past political theatre as well as spectral and phantasmatic quality of mediated images. 
Anna Kisiel in her "Spectral-Fragile-(Un)homely: The Haunting Presence of Francesca Woodman in the House and Space ${ }^{2}$ Series" delves into the spectrality of photography and its capacity to create the effect of indefinite presence and blurred subjectivity evading objectifying gaze and recognition. Focusing on the relation between the uncanny setting of an abandoned, yet uninhabited house and the artist's blurred figure, the author notices a possibility of viewing Woodman's photographs through the prism of disappearance, erasure, loss of self and failing subjectivity. However, instead she chooses to read spectrality in Woodman's art in affirmative terms through Bracha L. Ettinger's matrixial theory as self-fragilization and positive ghostly subjectivity.

Tymon Adamczewski's "Hauntology of Responsibility: Tom Stoppard's Darkside" focuses on the aspects of responsibility in the face of death, subversively questioning the very possibility of making right ethical choices. Hauntology is here employed to signal the validity of uncertainty and hesitation, of undecidibility and unverifiable emergency of critical situations. These aspects can be fully explored by examining the way the radio medium - with its use of sound and music — makes it possible to suspend voices, situations, or events between reality and imagination, existence and non-existence, truth and falsehood. Perhaps the most significant aspect of hauntology in Adamczewski's article is how Pink Floyd's album keeps haunting Stoppard's play and contemporary culture.

The articles collected in "Part Four: Ghostly Legacies" address two crucial aspects of haunting related to otherness and inheritance that are also intricately connected to matters of visibility and ways of (critical) looking. The spectre, as Derrida notes, "is the frequency of a certain visibility. But the visibility of the invisible" (Derrida, 1994, p. 100; emphasis in original), and therefore haunting requires a different kind of optics that may make it possible to notice what usually remains unseen, but what, though positioned on the margins or off centre, is still (in)visibly there. Haunting reverses the usual investigative procedures and requires that scholars "start with the marginal, with what we normally exclude or banish, or more commonly, with what we never even notice" (Gordon, 2004, p. 120), so as to finally acknowledge it as a significant part of the social. The recognition of the presence of the spectre entails a call to responsibility for choosing how to react to what the ghosts represent and to the inheritance that they make present. This possibility of choice fully uncovers the ethical dimension of hauntology and demonstrates that "inheritance is never a given, it is always a task" (Derrida, 1994, p. 54). The articles included in this part in various ways relate to the question of inheritance, or ghostly legacies, re-presenting the Others excluded from official histories and investigating some of the ways in which inheritance may be rejected or accepted.

In "Haunting across the Class Divide: Sarah Waters's Affinity and The Little Stranger," Barbara Klonowska proposes to approach haunting as a sign of social and political, rather than merely psychological phenomena, where the appearance of ghosts is a symptom of suppressed social conflicts and hidden animosities. Following Avery Gordon's suggestion that haunting should be seen as "a generalizable social phenomenon of great import" (Gordon, 2004, p. 106), Klonowska's analysis of Sarah Waters's Affinity and The Little 
Stranger focuses on class conflicts and economic inferiority to examine the ways in which ghosts function in the novels as a means of revenge and of "retribution exacted by the helpless and mistreated." Accordingly, Klonowska's article demonstrates that haunting is a means of social critique and a tool of justice, uncovering the seemingly invisible processes of social hierarchization and bringing in a different political agenda.

The connection between haunting, spectres and justice is also explored in Katarzyna Więckowska's "Spectral Economies in Graham Swift's Mothering Sunday: A Romance," in which ghosts are seen as figures of repressed otherness and unwelcome reminders of what has been excluded from the dominant culture. The analysis approaches Graham Swift's novella as a commentary on (literary) history and its economy of spectres, focusing in particular on the exclusionary procedures of literary modernism. Więckowska's examination of the spectres of modernism and the First World War illustrates the ways in which Swift's book questions the canonical representation of modernism and revises the conventional means of writing about the past, memory, and history. By situating the analysis in the context of various returns to modernism in discussions of contemporary culture, the author points to the degree, often unacknowledged, to which the present borrows from the past and delineates some of the multiple modes in which inheritance can be handled.

In "The Haunting Presence of the Feminine: Virginia Woolf in the Streets of London," Agnieszka Pantuchowicz analyses the ways in which Woolf's Modernist essay "Street Haunting: A London Adventure" mobilizes the figure of the flâneur to critique the masculine style of participating in the public sphere. Referring to the Gothic literary tradition, Pantuchowicz proposes to see haunting as feminine and to approach Woolf's stroller, apparently the flâneuse, as a "hauntess," who joyfully and playfully blurs the borders between the public and the private, or the home and the market. In this intricate reading of Woolf's essay, haunting becomes a means of transgression which deconstructs the existing gender hierarchies and introduces a new "politics of space" by "bringing the space of the Gothic confinement, and also of entombment, to the public."

Paweł Pyrka's "Haunting Poe's Maze: Investigative Obsessions in the Weird Fictions of Stefan Grabiński and H. P. Lovecraft" traces two different modes of inheriting from Edgar Alan Poe by analysing the ways in which his ideas concerning "weird" story writing were developed in the work of Stefan Grabiński and Howard Phillips Lovecraft. The study of Grabiński's and Lovecraft's fiction deploys the concept of the labyrinth, which, as Pyrka states, in Poe's writings "is in effect already an apparition, a half-being," and in whose vague space his descendants find themselves always already lost. The author convincingly argues that it is the spectre of Poe, or his legacy, that provides the "missing link" between Lovecraft's reactionary and "mechanistic materialism," and Grabiński's progressive "sense of 'amazement'," thereby demonstrating the importance of unexorcized ghosts to the progress of fiction.

The last section of the hauntological issue of AVANT contains three reviews of books published in 2016 and 2017, whose preoccupations are either directly related to the spectral themes or concern analogous concepts or phenomena. Mirosława Buchholtz's review of 
Liliana Sikorska's Being (Non)Human, or on the Topography of "Monsters" Medieval and Modern exposes the extent to which our contemporary understanding of humanity and monstrosity is haunted by the past conceptualizations. In their review of Tadeusz Rachwał's Precarity and Loss: On Certain and Uncertain Properties of Life and Work Katarzyna Więckowska and Edyta Lorek-Jezińska discuss the ways in which loss and uncertainty influence contemporary lives, identities, and conceptual systems, producing a state of unknowing that is uncannily similar to that heralded by the appearance of spectres. Finally, Olga Drenda's book whose Polish title Duchologia polska. Rzeczy i ludzie w latach transformacji could be translated into English as Polish Hauntology: Things and People in the Transformation Period, reviewed by Marek Jeziński, comments on how memory of the transformation period is dominated by ghostly recollections, disruptions, raptures and afterimages.

The artist whose works haunt the pages of this issue of AVANT is Anna Kola, a photographer, graphic designer, glass artist, working with intermedia. Her inter- and multidisciplinary art, involving combinations of tools, materials and techniques, is inspired by the surrounding world and nature, which — by artistic transformation - turn into a form of spectral image or ghostly recollection, or sometimes into an abstraction preserving only an almost invisible trace of the original object.

Among its many uses, hauntology offers the conceptual ground for both highly theoretical considerations and purely practical applications, thus blurring yet one more boundary, between thought and action. The remarkably unceasing appeal of hauntology testifies to its relevance to the concerns of the twenty-first century, whose beginning seems to be a time particularly exposed to various kinds of haunting. The articles collected in this issue illustrate the modes through which spectres may appear and delineate the methods of dealing with and inheriting from them. Hopefully, these studies may themselves become spectral, provoking further investigations of borders, gaps, and crossings in academic disciplines and research.

\section{References}

Blanco M. P., \& Peeren, E. (Eds.). (2013). Spectralities reader: Ghosts and haunting in contemporary cultural theory. London, UK: Bloomsbury.

Davis, C. (2005). Hauntology, spectres and phantoms. French Studies, 59(3), 373-379. https://doi.org/10.1093/fs/kni143

Derrida, J. (1994). Specters of Marx: The state of the debt, the work of mourning, and the new international. (P. Kamuf, Trans.). New York, NY: Routledge.

Derrida, J., \& Stiegler, B. (2013). Spectrographies. In M. del Pilar Blanco \& E. Peeren (Eds.), Spectralities reader: Ghosts and haunting in contemporary cultural theory (pp. 37-51). London, UK: Bloomsbury. 
Gordon, A. F. (2004). Ghostly matters: Haunting and the sociological imagination. Minneapolis: University of Minnesota Press.

Jameson, F. (2008). Marx's purloined letter. In M. Spinker (Ed.), Ghostly demarcations: A symposium on Jacques Derrida's Specters of Marx (pp. 26-67). London, UK: Verso.

Lorek-Jezińska, E., \& Więckowska, K. (2017). Hauntology and cognition: Questions of knowledge, pasts and futures. Theoria et Historia Scientiarum, 14: Spectrality and Cognition: Haunted Cultures, Ghostly Communications (E. Lorek-Jezińska \& K. Więckowska, Eds.), 7-23.

Matless, D. (2008). A geography of ghosts: The spectral landscapes of Mary Butts. cultural geographies, 15(3), 335-357. https://doi.org/10.1177/1474474008091331

Roach, J. (1996). Cities of the dead: Circum-Atlantic performance. New York, NY: Columbia University Press. 

Anna Kola, Remains III, digital print, 11x16 cm, 2011 
है

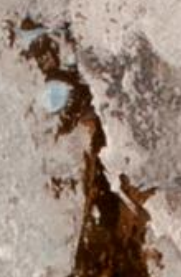

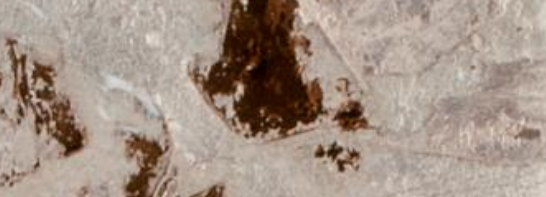

t9

2.

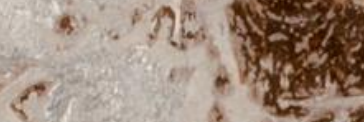

3. $\cap$ Ale 20 .

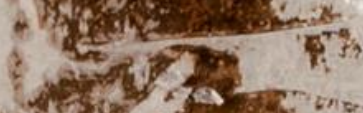

2.

2.

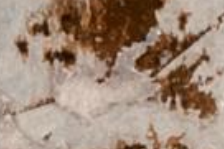

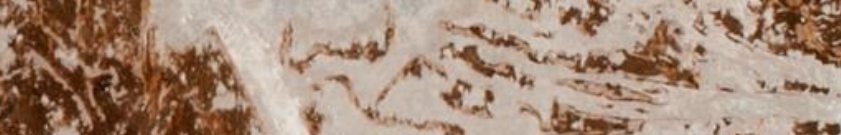

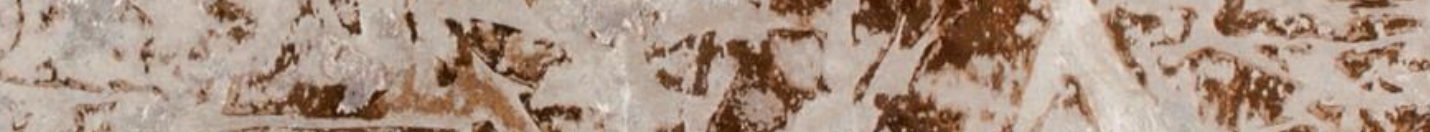

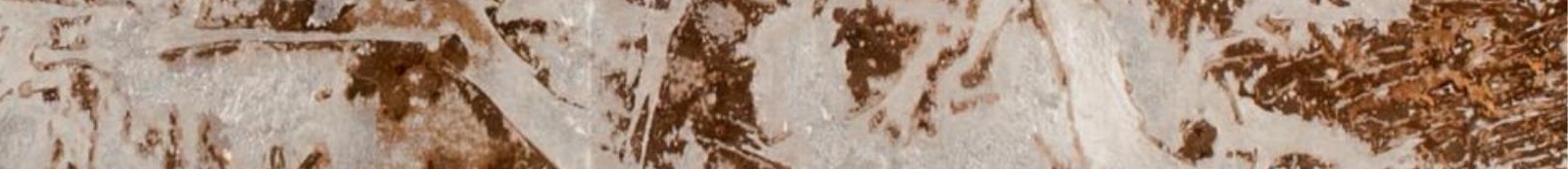
(3)

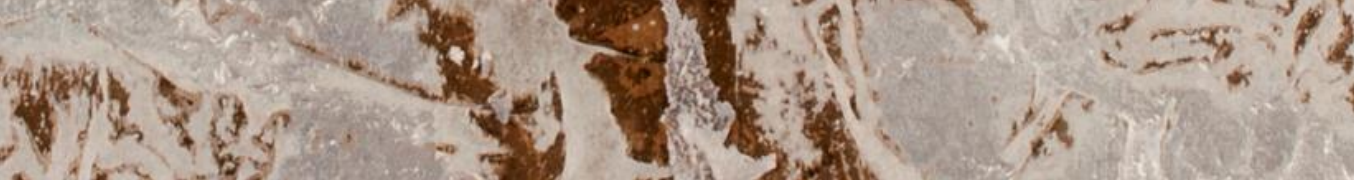
Af. (3)

(3)

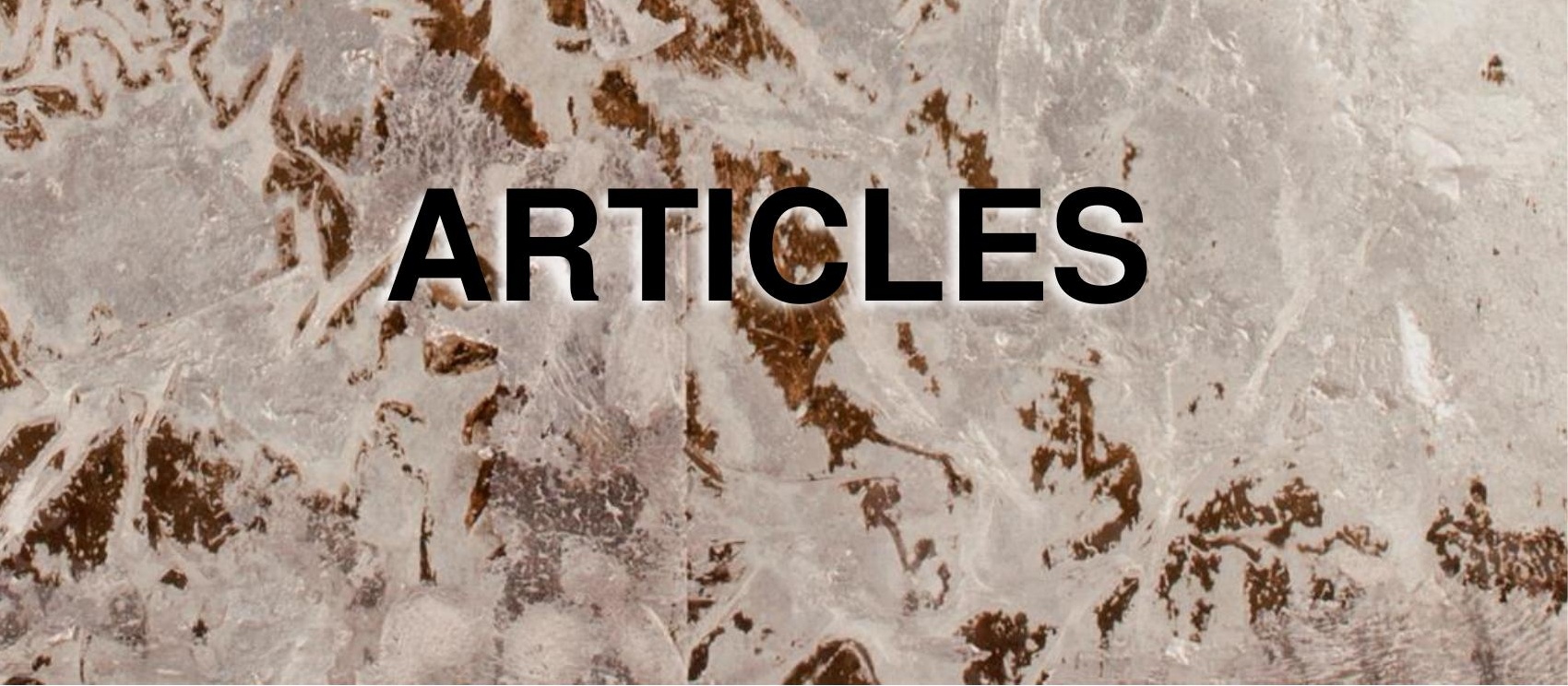


Anna Kola, $\boldsymbol{K}-\boldsymbol{I}$, steel, fused glass, aluminum foil, $50 \times 50 \mathrm{~cm}, 2009$ (fragment) 


\section{Part One: Ghost Writing}





\title{
Spectres of Paper: Writing, Digitization, and the End(s) of the Book
}

\author{
Tadeusz Rachwal \\ SWPS University of Social Sciences and Humanities in Warsaw \\ trachwal@swps.edu.pl
}

Received 6 May 2017; accepted 15 October 2017.

\begin{abstract}
This paper has been inspired by Jacques Derrida's statement revealing that his philosophical writings were mostly devoted to paper. "I have the impression," he said, "(the impression! - what a word, already) that I have never had any other subject basically, paper, paper, paper" (Derrida, 2005, p. 41). My paper addresses this thrice repeated noun as a name not so much of a material object on which we scribble, but as a space between the spirit and the letter, a space which turns out to be ineradicable even at the time of paper's alleged eradication in the e-textual age, which may be called a fin de livre culture. This end of the book, I argue, is a highly provisional declaration of the beginning of a paperless era of digitized media, which are not quite capable of eradicating various traces and spectres of paper haunting their own theorizations.
\end{abstract}

Keywords: paper; writing; digital; analog; spectral.

Hauntology has been strongly tied to the name of Jacques Derrida mainly in the wake of his Specters of Marx, the book inspired, as he writes, by the first noun-Ein Gespenstappearing in the text of the Communist Manifesto. What seems to have prompted him to speculate on haunting, however, seems to be another kind of spook, the apparition of paper - the phantom which he does not literally read as a ghost, but to whose haunting persistence he implicitly admitted in 2001 in an interview saying, and actually writing, that "I have the impression (the impression! - what a word, already) that I have never had any other subject basically, paper, paper, paper" (Derrida, 2005, p. 41; emphasis in original). This thrice repeated noun along with printing connotations carried by the parenthetically exclaimed impression brings to mind the possibility that paper is not only what we write on, but also something which is itself written, impressed or scribbled as an ineradicable trace which contaminates the innocent whiteness, or blankness, of the page. Saying that he 
has the impression, Derrida does not express any certainty as to the subject of his writing, for in addition to imprinting or stamping, the noun "impression" also strongly alludes to vagueness, elusiveness and haziness which, in turn, bring to mind a haunting spectrality of the italicised subject. Slightly reformulating the sentence one could say that paper haunts Derrida and thus imprints itself as a possession ("I have the impression"), as a property, even a private one, whose disappearance haunted Europe through Karl Marx's Ein Gespenst.

Let us say, provisionally, that paper is impressed, or imprinted, in culture not only as the usually white carrier of writing, but also as the possibility of writing which lives on and survives even now in the epoch of digitization which, for some, is a promise of there being a paperless knowledge, a paperless information, a paperless truth. When Derrida wrote in Of Grammatology about the end of the book, he simultaneously envisioned the beginning of writing in which he saw a liberation of what now could be termed textuality, a liberation of the written against pure presence disguised in the form of the book. For Gayatri Spivak the chapter which announces this beginning ("The End of the Book and the Beginning of Writing") is "full of a slightly embarrassing messianic promise" (Spivak, 1997, p. 1xxxi). The announcement of the end of the book could be called messianic because the revelation of the phonocentric nature of culture and of its repressive treatment of writing were seen, or at least described by Derrida, as "historically necessary events" (Spivak, 1997, p. lxxxi). This alleged historical determinism, however, seems not to be so much a prediction of a future, but rather a statement of fact, of the factuality of writing, and of paper, which for a long time was exorcised by the philosophical phonocentricity in which the materiality of writing, and of paper, were treated exactly as spectral, as the pure visibility hiding the invisible truth which, unlike paper, was to be permanent and eternal.

Perhaps the message was that ours is a paper culture which hides its own vulnerability by way of relegating it to the outside, to paper and writing which, like ghosts, lurk there as threatening to its otherwise immutable fixity and permanence. The end of the book, its approach which Derrida sees as the "death of the civilization of the book" is manifested, or manifests itself, paradoxically not through a disappearance of the book, but "through a convulsive proliferation of libraries" (Derrida, 1997, p. 8) in which books, orderly numbered and catalogued, offer access to knowledge now contained in the huge archive which controls writing, keeps it in place, and through now electronic systems makes writing immediately accessible — makes writing, as it were, speak. Once external and supplementary to speech, writing gained the strength of immediacy which precedes inscription, and which thus precedes paper and comes from within without the necessity of paper's mediation:

And thus we say "writing" for all that gives rise to an inscription in general, whether it is literal or not and even if what it distributes in space is alien to the order of the voice: cinematography, choreography, of course, but also pictorial, musical, sculptural "writing." .. All this to describe not only the system of notation secondarily connected with these activities but the essence and the content of these activities themselves. It is also in this sense that the contemporary biologist speaks of writing and pro-gram in relation to the most elementary processes of information within the living cell. And, finally, whether it has essential limits or not, the entire field covered by the cybernetic program will be the field of writing. (Derrida, 1997, p. 9) 
Having the impression that his subject was "paper, paper, paper," Derrida in a sense posits his writing as an autobiography and himself as paper, the seemingly passive carrier of writing for which some kind of pressing, and thus of violence, is essential - the pressure of a quill, of a pen, or a pencil, the pointed objects about which he wrote in Spurs. Having the impression, carrying it, he in fact posits his writing not to be about writing, thus as it were impersonating paper which he simultaneously claims to be his subject, the subject which he has always had. If Jean-Jacques Rousseau famously wrote in Confessions that he was a book, Derrida seems to be saying that he was paper, the whatness of his subjectivity being but an impression, an imprint on the otherwise blank space whose presence consists in disappearance, in being reduced by writing, marginalized into a margin - the theme which he also took up in White Mythology. Writing devours paper, and the imagined threat of its disappearance in the electronic age, in the age of word processing, has only enhanced the nostalgia for paper whose spectre does live on, reflected in the vocabulary of electronic media. We still write papers, though we can do it without touching paper, and though now I am writing a paper on paper seeing only a keyboard and a screen, the digital kind of existence of this writing posits it as removed from both and situates it within the electronic memory, makes it immaterial and untouchable, exiled. Yet this exile seems to be nothing new and it goes hand in hand with the nostalgia for the unwritten, for the whiteness of innocence always already spoilt by inscription.

Marks left on paper cannot be fully trusted, and Descartes's reduction of being to thinking, performed quite a long time ago, was also an expression of the desire to write without writing, to write in the air, or perhaps in the spirit, without the necessity of touching paper with the tip of the pen. "While I am writing," he wrote in Rules for Direction of the Mind,

at the very moment when the various letters are formed on the paper, it is not only the tip of the pen that moves; there could not be the least movement of this that was not at once communicated to the whole pen; and all these various movements are also described in the air by the top end of the pen; and yet I have not an idea that something real travels from one end of the pen to the other. (Descartes, 1954, p. 161)

The very title of Descartes's text expresses a longing for control of thinking rather than writing, an aspiration to manage the movements of the mind which should not be dispersed. The movements described in the air do not guarantee the certainty of the real, and writing does not guarantee the emptying of the mind of the illusory, the performance of what Michael Oakshott calls the "intellectual purge" which begins Descartes's search (Oakshott, 1962, p. 21). In the time of the digital writing this purge seems, or promises, to have been accomplished by way of virtualization which also carries a promise of final transformation from the written to the virtual, which in the subtitle of Wim Westera's book on the digital turn figures as transformation of our existence (The Digital Turn: How the Internet Transforms Our Existence, 2012). Virtualization figures in his book as an implicit promise of the final transformation, of virtual reality's eventual replacement of our imperfect rootedness in the world of our bodies, minds, of pens and papers. In fact, 
this goes hand in hand with the faith in boundless possibilities of technological advancements which will bring us to another world, the world of simulation offered as a new world of sorts to which we, literally, immigrate:

We disconnect the mind from the body and thereby transfer ourselves from the real world to the simulation. We are real-world immigrants in a simulated realm, where we can interact with other immigrants or with artificial characters without noticing any differences. This would be the ultimate virtual reality because the body is frozen while the brain, which would still be processing sensory data and controlling motor actions, is still active. We might want to keep our brain in a vessel and renounce our brainless body. (Westera, 2012, p. 125)

This world of simulation is one which seems to have been freed from haunting by the origin, a perfect simulation which is freed from nostalgia. If for Baudrillard even geometric simulations of the world were akin "to the nostalgia for living forms that haunts geometry" (Baudrillard, 1989, p. 7), the ultimate virtual reality to which we immigrate should ideally make us immigrants without the haunting memory of the old. This achievement is, for Baudrillard, what is asserted by America, but this assertion can also be seen in what is asserted in the digital program of perfecting reality. Baudrillard's modest vision of us as nostalgic Utopians is strongly undermined by the lack of utopianism in various manifestos of the perfection of the digital. For Baudrillard, "[w]e shall remain nostalgic Utopians, agonizing over our ideals, but baulking, ultimately, at their realization, professing that everything is possible, but never that everything has been achieved. Yet that is what America asserts" (1989, p. 78).

This "American" assertion of the achievement speaks, for example, through the idea of Immersive Virtual Environment technology used in psychology, whose proponents describe the virtual as "the ultimate representational system" allowing the observer "to interact 'naturally' with objects and other individuals within a simulated environment or 'world,' an experience indistinguishable from 'normal reality"' (Loomis, Blascovich, \& Beall, 1999, p. 557). The strength of digital technologies lies in their potential to blur "the distinction between reality and its representation" (Loomis, Blascovich, \& Beall, 1999, p. 557) in a representation which replaces the represented. This assertion, before the digital turn, was discernible in Benoit Mandelbrot's fascination with fractals and the idea of transforming the irregularities of nature through mimicking "reality by purely geometric means" (1977, p. 84) with which he, literally, "attacks irregularity" (1977, p. 12). Such projects express the dream of an ideal philosophical language, the idea itself rooted in Jacques Derrida's critique of metaphysics of presence in which the ideal was also posited virtually, though not through mathematical or, later, digital means.

What is also significant in the attempts at the erasure of the nostalgic is the envisioning of the digital as purer and cleaner than analog representations of reality. The superiority of the digital is rhetorically marked in Westera by the separation of the brain from the body, which suggests that the brain/body opposition is one in which the brain may well stand for mind, soul, and thinking as opposed to the impurity and limitations of the body. The analogue world is rhetorically projected as less perfect, as an ambiguously and linearly represented 
world which the digital representation purges of disturbances and noises. The effects of "digitization," which converts streams "of analog information into digital bits of $1 \mathrm{~s}$ and $0 \mathrm{~s}$ with discrete and discontinuous values" (Kreiss \& Brennen, 2014) are neatly outlined by Daniel Kreiss and Scott Brennen who discuss the problem on Culture Digitally webpage:

As communication scholar Tony Feldman (1997, p. 2) argues, unlike analogue data with "continuously varying values, digital information is based on just two distinct states. In the digital world, things are there or not there, 'on' or 'off'. There are no in-betweens." That digital bits have only two possible values leaves many to argue that, in the words of Robert Pepperell (2003, p. 126), "digital information is discrete and 'clean', whilst analogue information is continuous and 'noisy'." Robinson (2008, p. 21) defines analog as: "smoothly varying, of a piece with the apparent seamless and inviolable veracity of space and time; like space and time admitting infinite subdivision, and by association with them connoting something authentic and natural, against the artificial, arbitrarily truncated precision of the digital (e.g., vinyl records vs. CDs)." (Kreiss \& Brennen, 2014)

Unlike the digital, the analog awakens nostalgias of authenticity and nature, but what lurks in it is the possibility of inadequacy and error. Robert Pepperel, referred to in the above quotation, underlines this proneness to error linking it with the simplicity of digital encoding:

The processing, communication and replication of digital data is much less prone to error than that in an analogue system because of the relative simplicity of the encoding system, which is a string of $1 \mathrm{~s}$ and $0 \mathrm{~s}$. Because the data in an analogue machine is not represented discretely (in the same way as it is in a digital machine), it is much more complex to store and duplicate, with the consequence that error is more likely to creep in. (Pepperel, 2003, p. 126)

This alleged immunity to error is also responsible for the mythization of the perfection of the digital and for the long-standing image of immateriality of digitized information. As Marlene Manoff argues, at the earlier stages of digitization the dominant perception was that of "the immateriality of the digital domain and the related assumption that it was somehow enabling us to transcend matter" (2013, p. 276). This new metaphysical promise is gradually giving way to the realization of the obvious, though rhetorically clouded, material rootedness of digital information and what has begun to be more and more frequently addressed, she claims, is "the need for more materialist thinking" (Manoff, 2013, p. 276). This new materialism consists not only in the realization that the storage of digital information uses space, energy and hardware, but also in the realization of the more distant nature of the material which was only moved away from the sphere of the vision, and not virtualized. "The cloud," for example, "does not virtualize network support, it simply relocates it to distant energy-devouring data centers" (Manoff, 2013, p. 276). Though no longer written on paper, data are not hovering in the air like clouds, and though the name of "the cloud" strongly suggests this possibility, it also refers now to an archive, to a material place where documents and books are stored. The figure of Descartes's writing with its top end of his pen in the air can be brought here as a metaphor of the distancing of the material marks left of paper, the distancing which, however, does not remove the material, the paper, which, as it were, spoils the alleged immateriality of digital information, blurs it with its analog origin. As Wolfgang Ernst claims, however, archive is now a nostalgia 
and "a phantasm surviving from the age of print" (2006, p. 120), the persistence of that phantasm and its resistance to becoming purely virtual may well be called the resistance of paper which spectrally returns in the abused terms, albeit catachretically. A webpage is still a page, and there are documents in the docuverse. The page is, as Jacques Derrida saw it, "primarily a figure of paper (of the book or codex)," noticing in Paper Machine that

the page nowadays continues, in many ways, and not only metonymically, to govern a large number of surfaces of inscription, even where the body of paper is no longer there in person, so to speak, thus continuing to haunt the computer screen and all internet navigations in voyages of all kinds. (Derrida, 2005, p. 46)

Voyages of all kind eventually lead to a library, to an archive, regardless of various declarations of what Manoff calls "the obsolescence of print and the death of the codex" (2013, p. 276). These are advanced, she notices, "as part of the validation and promotion of new digital products. Many library mission statements and planning documents participate in the production of these narratives of digital ascendancy and the supersession of the book" (Manoff, 2013, p. 276). Though the archive has changed, freed itself from the demand of strict ordering and became a virtual "an-archive" (cf. Ernst, 2006, p. 120) of sorts, the analog imperfection returns to it through various figurations of paper, perhaps through some drive of imperfection which contaminates it with vulnerability to spam, viruses, bugs and glitches constituting the dark side of digital culture (cf. Sampson \& Parikka, 2009). Perhaps paradoxically, the new world without paper, which was one of the promises of the multimedial cyberspace, cannot overcome its own anomalies because of paper which reappears, or haunts us, through the technological advances which deny it, which foretell its loss, which write its loss beginning with the techne of writing itself, of leaving signs on paper which, for Descartes, were marks of the uncertainty of the real. These signs were simultaneously signs of moving forward, signs of advance which, as Derrida has tried to show, removed the support of paper, in fact virtualized it:

Every sign on the paper had to be picked up as an advance sign: it foretold the "loss" of a support: the end of the "subjectile" is nigh. That is also, doubtless, where this body of paper has a bodily hold on us. Because if we hold to paper, and will do for a long time to come, if it gets hold of us bodily, and through every sense, and through every fantasy, this is because its economy has always been more than that of a medium (of a straightforward means of communication, the supposed neutrality of a support) — but also, paradoxically . . . that of a multimedia. It has always been so, already, virtually. (Derrida, 2005, p. 42)

The disappearance, or loss, of paper is a part of its economy which is, in fact, governed, again paradoxically, by inevitable reappearance, by a haunting return which is also a return of a disappearance. Hence the multimedial character of paper which Derrida, perhaps surprisingly, ascribes to it. In the virtual space, at least according to Wolfgang Ernst, multimedia are also subject to "loss" in the manner paper is lost in the case of a computer screen. "A close reading of the computer as medium," writes Ernst, "reveals that there is no multimedia in virtual space, only one medium, which basically calculates images, words, sounds indifferently, since it is able to emulate all other media. The term multi-media is a delusion" (2006, p. 108). 
Though digital, multimedia are, as it were, too analog for Ernst. They are streams rather than bits and, perhaps unlike in a truly digital world where, as we have seen, "things are there or not there, 'on' or 'off'" (Pepperell, 2003, p. 126), they are not quite there. If writing on paper harbingers its disappearance, multimedia harbinger the loss of digital space which, like paper, supports appearances at the cost of imperfection. It is in this sense, it seems, that Ernst reads the term multimedia as a betrayal: "The term multi-media is thus an interfacial betrayal on the computer screen: in digital space: the difference between the aesthetic regimes only exists for the human user, simulating the audio-visual human senses under one surface" (2006, p. 108). Between the white surface of paper and the one surface of something which might be called a mono-medium falls the shadow of the senses which "work" analogically, imperfectly regimenting and dividing these two haunting presences into books, texts, pages and webpages in accordance with the aesthetic regimes which we make up by ourselves. This division, or partition, of the sensible (cf. Rancière, 2010), even the partition into pages - be it book-pages or web-pages - is haunted by paper whose smoothness and whiteness is illusory. For paper seems to be multimedially programmed and under its innocent whiteness, "beneath the appearance of a surface, it holds in reserve a volume, folds, a labyrinth whose walls return the echoes of the voice or song that it carries itself; for paper also has the range or the ranges of a voice bearer" (Derrida, 2005, p. 44). It is this program, or rather pro-gramme, the proto-writing of grammatology which does not allow paper to simply become absent and prolongs "the afterlife of paper-far beyond its disappearance or its withdrawal" (Derrida, 2005, p. 46). This pro-gramme includes the possibility of digital programming, though its execution, or performance, is left to Ernst's "human senses," to the analog imperfection which need not be necessarily treated as the revenge of analog (as the title of David Sax's recent book suggests; cf. Sax, 2016) expressed in growing sales of vinyl records and Moleskin notebooks, but rather as a way of reminding that the spectral presence of paper may be an incentive to thinking that paper's complex technological and material history, along with the symbolic history of its projections and interpretations, is "a history tangled up with the invention of the human body and of hominization" (Derrida, 2005, p. 43). Paper did, and does, take part in the making of the human and though in the digital world it is not seen "in person," as Derrida phrased it in one of the above quotations, its spectre haunts not only its origin but also its uses and abuses in the contemporary world which is, as it seems, always already more than one.

\section{References}

Baudrillard, J. (1989). America. (C. Turner, Trans.). London, UK: Verso.

Derrida, J. (1994). Specters of Marx: The state of the debt, the work of mourning and the new international. (P. Kamuf, Trans.). New York, NY: Routledge.

Derrida, J. (1997). Of grammatology. (G. C. Spivak, Trans.). Baltimore, MD: John Hopkins University Press. (Original work published 1967)

Derrida, J. (2005). Paper machine. (R. Bowlby, Trans.). Stanford, CA: Stanford University Press. 
Descartes, R. (1954). Rules for direction of the mind. In E. Anscombe \& P. T. Geach (Eds. \& Trans.), Descartes: Philosophical writings (pp. 153-180). London, UK: Nelson

Ernst, W. (2006). Dis/continuities: Does the archive become metaphorical in multi-media space? In W. Hui Kyong Chun \& T. Keenan (Eds.), New media, old media: A history and theory reader (pp. 105-124). New York, NY: Routledge.

Feldman, T. (1997). An introduction to digital media. New York, NY: Routledge.

Kreiss, D., \& S. Brennen. (2014, September 8). Digitalization and digitization. Culture Digitally. Retrieved April 21, 2017 from http://culturedigitally.org/2014/09/digitalization-and-digitization/

Loomis, J. M., Blascovich, J. J., \& Beall, A. C. (1999). Immersive virtual environment technology as a basic research tool in psychology. Behavior Research Methods, Instruments, \& Computers, 31(4), 557-564.

Mandelbrot, B. B. (1977). The fractal geometry of nature. New York, NY: W.H. Freeman \& Company.

Manoff, M. (2013). Unintended consequences: New materialist perspectives on library technologies and the digital record. Libraries and the Academy, 13(3), 273-282.

Oakeshott, M. (1962). Rationalism in politics and other essays. London, UK: Methuen.

Pepperell, R. (2003). The posthuman condition: Consciousness beyond the brain. Portland, OR: Intellect Books.

Rancière, J. (2010). Dissensus: On politics and aesthetics. (S. Corcoran, Trans.). London, UK: Continuum.

Robinson, D. (2008). Analog. In M. Fuller (Ed.), Software studies: A lexicon (pp. 21-31). Cambridge, MA: MIT Press.

Sampson, T. D., \& Parikka, J. (Eds). (2009). The spam book: On viruses, porn, and other anomalies from the dark side of digital culture. Cresskill, NJ: Hampton Press.

Sax, D. (2016). The revenge of analog: Real things and why they matter. New York, NY: Public Affairs.

Spivak, G. C. (1997). Translator's preface. In J. Derrida, Of grammatology (pp. ix-xc). (G. C. Spivak, Trans.). Baltimore, MD: John Hopkins University Press.

Westera, W. (2012). The digital turn: How the internet transforms our existence. Bloomington, IN: AuthorHouse. 


\title{
J'accepte: \\ Jacques Derrida's Cryptic Love by Unsealed Writing
}

\author{
Michal Krzykawski \\ University of Silesia in Katowice \\ michal_krzykawski@poczta.fm
}

Received 23 April 2017; accepted 6 October 2017.

\begin{abstract}
This article focuses on the autobiographical ghost that dwells in "Envois" and the multiple ways he/she/it interferes in Derrida's concept of écriture. Read through love letters sent as postcards with the image representing Socrates writing in front of Plato, Derrida's writing, I argue, definitely becomes a cryptic writing (écriture cryptique) both in the sense of kryptô (Gr. coded) and secerno (Lat. set apart). I endeavor to show that "Envois"-largely autobiographical and entangled in his life events - is a harbinger of the secret that Derrida takes for a fundamental feature of democracy in his later works. And yet the secret is of his own, as he notes when writing "Envois": "Nobody will never know what the secret I write along with is. And that I say this will not change anything" (Peeters, 2010, p. 367).
\end{abstract}

Keywords: autobiography; love; crypt; secret; writing.

At the moment I leave "my" book (to be published) — after all, no one forces me to do itI become, appearing-disappearing, like that uneducable specter who will have never learned how to live. The trace I leave signifies to me at once my death, either to come or already come upon me, and the hope that this trace survives me. This is not a striving for immortality; it's something structural. I leave a piece of paper behind, I go away, I die: it is impossible to escape this structure, it is the unchanging form of my life. Each time I let something go, each time some trace leaves me, "proceeds" from me, unable to be reappropriated, I live my death in writing. (Derrida, 2007, pp. 32-33)

When a philosopher confesses that he lives his death in writing, such a confession entails two problematic issues. He seems to admit that the immense philosophical writing he is widely known for might or even should be read as an autobiographical project. But, since death is "the always-already-there" (Derrida, 1989, p. 117) of his life, to quote the formula from Derrida's first book, autobiography can only appear as a spectre that haunts his writing. Crudely speaking, a man who once lived and was named Jacques Derrida hovers over 
the words he uses. Hence, his ghost also haunts those who refer to his philosophical concepts: dissemination, trace, hauntology, survival [survie], animots, just to name a few. In the last interview, originally published in Le Monde three weeks before his death, Derrida says: "one has not yet begun to read me . . . even though there are, to be sure, many very good readers (a few dozen in the world perhaps, people who are also writer-thinkers, poets)" (2007, p. 34). Then, how and where to begin from? To begin to read Derrida, I argue, means to familiarize oneself with his spectral presence that haunts Derridean philosophy.

One of Derrida's permanent obsessions might be rendered in these terms: my proper language will have never belonged to me. It expropriates me every time I come to life through my writing. I am my own ghost. However, writing from within such a belief clearly necessitates a methodical self-staging. This article particularly focuses on the presence of autobiographical ghosts that dwell in "Envois," the first part of The Post Card: From Socrates to Freud and Beyond (Derrida, 1987). However, as it is a part of a larger research project on the relation between auto/biography and philosophy, I will start by describing the highly problematic status of auto/biography in philosophical discourse using Nietzsche as an example. Indeed, auto/biography, I argue, may be seen as a ghost that haunts modern philosophy, while a philosopher is not expected to directly refer to his life experience when doing philosophy. ${ }^{1}$ From this perspective, "Envois" is of particular relevance. Discussing Derrida's text, I will follow three steps. First, choosing a biographical approach to "Envois," I will focus on a love affair that seems to act as a trigger for Derrida's écriture and largely responds to what he refers to as a secret. Then, working on Richard Rorty's assumption that Derrida "is trying to create himself by creating his own language game" (1989, p. 133), I will discuss how his approach to love interferes in his fundamental concepts such as différance, trace and dissemination. Finally, I will endeavour to show that Derrida's writing, performed by love letters sent as postcards and, as a result, challenging the distinction between the private and the public, becomes a cryptic writing [écriture cryptique]. It is both coded [krypto] and set apart [secerno]. Thus, unlike Rorty, who seems to highlight that "Envois" resists any procedure of reading, I will indicate a specific code in Derrida's text. Using the notion of the crypt, I will show that Derrida's love follows what Abraham and Torok refer to as "the cryptonymic procedure" (Abraham \& Torok, 1986, p. 21).

\footnotetext{
${ }^{1}$ My ongoing research on what I refer to as "auto/biographical philosophy" mainly concerns male philosophers (Bataille, Blanchot, Derrida, Nancy and Stiegler). The question about auto/biography in philosophy should be posed, I believe, with gender sensitivity and bearing in mind sexual difference. From a general perspective, I would be inclined to argue that the absence of auto/biography in philosophical discourse coincides with the absence of women in the history of philosophy, which results from women's social and cultural condition. As long as the power of reasoning (and philosophizing) is defined as male, the question of bios (biography and biology) appears as female. In my research, however, I intend to go beyond this general perspective, paying attention to how particular and heterosexual male philosophers define, are determined by and refer to their masculinity in their writings and how they describe their relationships with women. It would be highly interesting and useful to apply this approach in relation to particular female philosophers to see not only how they come to philosophy as women and how they become women-philosophers, but also how they refer, if ever, to their femininity. Do they have the same strong will to write themselves through their philosophical projects as male philosophers do? From this perspective, Catherine Malabou's philosophical project is of crucial interest in my research.
} 
A reflection that has been with me for a while is that we simply ignore the biographies of philosophers as something external to their philosophy, whereas we are perfectly familiar with the biographies of writers or artists as something that might explain some fragments of their oeuvre. In fact, it is common knowledge that the life of a philosopher has nothing to do with his or her thought. We seem to be quite post-Romantic in our ways of thinking thought itself. Romanticizing thought, we somehow take it for granted that life in its contingency does not affect it at all. As a result, detecting ties between life and thought when dealing with a philosopher would imply frivolous psychologizing of philosophical concepts or seeing in the history of thought nothing but a sad reflection of personal affairs. It is as if the very right to auto/biography as an inherent part of the oeuvre was an effect of being (qualified as) a writer. It is as if, when dealing with a philosopher's writing, our academic practices of analysis, for their seriousness' sake, condemn as a matter of course and in the name of some invisible philosophical authority any kind of simplest questions that one could ask when thinking of writers: what were they like? What were they thinking about when they wrote this or that? What was the role of their significant others in their thought? If such questions appear as ill-chosen ones just because they target a philosopher and not a writer, one might see here the incontrovertible evidence of an interdiction that it would be interesting to investigate.

Jacques Derrida often questioned the absence of auto/biography within philosophical discourse. When giving quite a spontaneous lecture at New York University in 1996, he pointed out that traditional philosophy defines biography as external to philosophy. When Heidegger, Derrida says, was asked: "What was the life of Aristotle?", he replied: 'He was born, thought and died.' And all the rest is a pure anecdote" (Dick \& Ziering Kofman, 2005 , p. 60). From this perspective, stepping into philosophy through auto/biography binds us to invoke ghosts and question an absence that is almost palpable. Heidegger himself, with his Schwarze Hefte, may be a salient example of this.

Were we to believe that to philosophize, generally and particularly, simply and essentially, is to learn to live, which would ultimately mean to learn to die (Derrida, 2007, p. 24), it is striking that we are somehow taught, when learning to live, not to pay too much attention to the life experiences of our teachers. We learn how to live from those who are supposed not to have (had) their lives. And if they have one, we are willing to consider it a reflection of their philosophy and, as a result, to recognize their intellectual biography in which life becomes both understandable and relevant only when it stems from a philosophical doctrine. Materially speaking, the lived [le vécu] is not a lesson to be learned from. It gives way to the idea of life. However surprising it may seem, life as such may be seen as a ghost that haunts what Derrida refers to as "traditional" philosophy.

And yet, "traditional" here seems to refer less to philosophy as an ensemble of texts that are at our disposal whenever we want to learn to live. It rather refers to what we want these texts to mean for us. Philosophy defined as "traditional" is, in fact, a strange way in which 
we maintain that philosophy matters and overlook the material conditions of its production as something immaterial to philosophy. The invisible ghost of autobiography that hovers over philosophy strangely has a material presence.

Nietzsche is perhaps the first who made this ghost speak through philosophy so loudly. Certainly, in his autobiography Nietzsche writes: "I am one thing, my writings are another" (2007, p. 36), while in the preface to his most personal text he says: "But let us leave Mr Nietzsche: what is it to us that that Mr Nietzsche has got well again" (2001, p. 4). But both to Nietzsche and those who read his writings because they wish to learn to live and want to understand why he writes such good books, to recall the title of a chapter from his autobiography, it seems that the simple fact that Nietzsche has got well again does matter:

This book might need more than one preface; and in the end there still be room for doubting whether someone who has not experienced something similar could, by means of prefaces, be brought closer to the experiences of this book. It seems to be written in the language of the wind that brings a thaw: it contains high spirits, unrest, contradiction, and April weather, so that one is constantly reminded of winter's nearness as well as of the triumph over winter that is coming, must come, perhaps has already come... Gratitude flows forth incessantly, as if that which was most unexpected had just happened - the gratitude of a convalescentfor recovery was what was most unexpected. "Gay Science": this signifies the saturnalia of a mind that has patiently resisted a terrible, long pressure - patiently, severely, coldly, without yielding, but also without hope - and is now all of a sudden attacked by hope, by hope for health, by the intoxication of recovery. (Nietzsche, 2001, p. 3)

Nietzsche philosophizes with gaiety because he has recovered. His science has been gay since his painful headaches unexpectedly stopped for a moment. The sickness of Europe, which he sees as "a patient who owes the utmost gratitude to his incurability and to the perpetual changes in his affliction" (2001, p. 49), is first his own.

I do not claim that Nietzsche's recovery is essential to understand his philosophical thought. I rather suggest that it is of the essence. It is both an example and exemplar of how a singular subject answers to, but also for and before the world, to exploit - in the wake of Derrida's concept of responsibility (1992a, 2002) - the full range of meanings of the Latin verb respondere, through the way s/he experiences it. That this experience is first bodily and essentially material may matter for those of us who want to learn how to read and live. In fact, a lesson we can learn from Nietzsche's gay science is that healthy experience gives birth to some enlightening ideas. Nietzsche's fresh ideas about Europe sinking into what he refers to as nihilism, are an example. It would also explain that his general opinions about woman and sex, "often shallow and sometimes embarrassing, ... . were the product of an experience which had been drastically limited and disappointing" (Williams, 2001, p. xi).

Deliberately materialist, an auto/biographical approach to philosophy I opt for here may be seen as a method of doing philosophy defined as learning to live, which makes it possible, however, to go beyond its general and idealistic presumptions, as long as the question of life is concerned. Putting special emphasis on the interplay between experiencing the world and conceptualizing it, this approach, I believe, also provides a helpful tool for critical reading, 
which ultimately enables us to see the light, i.e. to live/read well, which amount to living/reading critically. My way of reading philosophy is that of a philologist who tries to see the sense of a singular oeuvre as a result of an experience that his/her author refers to more or less conspicuously. Perhaps, to a "traditional" philosopher, this materialist reading may be immaterial. But if the sense of philosophy still has to be about learning to live in a "posttruth" world, it has to stem from a philological curiosity and an appetite for meaning.

Ultimately, what philosophy means to us largely depends on what kind of questions we ask when reading in order to learn to live. In a documentary film about Derrida by Kirby Dick and Amy Ziering Kofman, an off-camera voice asks Derrida what he would like to learn from a documentary film about Heidegger, Hegel or Kant. After a longer moment of silence, Derrida - ill at ease, manifestly irritated but still determined-says that he would like to hear them speak of their sexual life. He also would like to know, as he adds, why they appear as asexual beings through their writings and why they wiped out their private life from their philosophy. From this perspective, to philosophize in order to learn to live entails asking straight and non-philosophical questions that require, however, mostly philosophical answers.

Discussing auto/biography in the context of "Envois" involves asking not only whether a philosopher is entitled to write his autobiography and whether we are entitled to discuss his thought in relation to his life, but also whether a philosopher has the right to love. How does loving affect thinking? Can we be in love and think at the same time, given the fact that love, pragmatically speaking, is something we necessarily fall in? Derrida not only questions "traditional" philosophy that makes it somehow impossible, from a rhetorical point of view, to inscribe the autobiographical in the philosophical, but he also untiringly tries to invent an idiom that would bear his experience. In a personal note from 1976, quoted by his biographer, Derrida refers to the idea of a book that would transform what he calls his "approach to anecdote which is strangled, tense and repressed" (Peeters, 2010, p. 361). From now on, Derrida will refer to this project as "the impossible," whenever his autobiographical ghost will appear in many of his texts, for example in Specters of Marx which opens with some kind of an avowal: "Someone, you or me, comes forward and says: I would like to learn to live finally" (Derrida, 1994, p. xvi).

In this respect, "Envois" is of particular importance. On the one hand, Derrida writes the text when, so to speak, his autobiographical urge is at its peak: he is obsessed by an idea of a fully autobiographical book which is supposed to be different from what he has written so far. On the other hand, he writes "Envois" in order to give voice to his love, yet this love, as I will try to show, is supposed to remain secret and, as a result, has to be ciphered. In 1972 Derrida gives a lecture on Nietzsche, published later as Spurs: Nietzsche's Styles. He starts this lecture by recalling a letter sent by Nietzsche in 1872, which is rather loosely connected to his argument (he translates the letter and puts his comments in):

From Basel in seventy two (The Birth of Tragedy) Nietzsche writes to Malvida von Meysenbug. ... At last my little bundle (or the little envelope (pli): mein Bündelchen für Sie. Will it ever be revealed, what was thus named between them?) is ready for you, and at last you hear 
from me, after it must have seemed that I had sunk into a dead silence (grabesschweigen).... You see, my Birth of Tragedy has made of me the most offensive [the most scabrous] philologist of the present day (der anstoßigste Philologe des Tages). (1979, pp. 34-35)

Derrida continues in a rather nebulous way: "the title for this lecture was to have been the question of style. However - it is woman who will be my subject. Still, one might wonder whether that doesn't really amount to the same thing — or is it to the other?" (pp. 35-37). Feminist interpretations of Derrida's reading of Nietzsche point out that "Derrida's analysis challenges the structural apparatus that sustains the reproduction of patriarchy. Nonetheless, the style of Spurs clearly betrays its masculine signature, and thereby participates in this reproduction" (Feder \& Zakin, 1997, p. 24). Putting aside the masculine character of Derrida's signature, it has to be said that Nietzsche here is first of all a "transferential figure" (Derrida, 1992b, p. 364) through which Derrida seems to write/cipher his own "birth of tragedy." Written between 1977 and 1979, "Envois" refers to his long and passionate love affair with Sylviane Agacinski. It begins in 1972 precisely and was tacitly accepted by Derrida's wife and his intellectual entourage (Peeters, 2010, pp. 358-359). "A taste for the secret" (Derrida \& Ferraris, 2002) Derrida would have recognized as his own stems, perhaps, from what has to be left unsaid, as if the secret had to be known and kept by everyone, which means that no one can actually reveal it.

The air of a strange open secrecy that hovers over Derrida's love affair gives us a better insight into what Derrida understands as love and how he ciphers his love by what legal English refers to as "unsealed writing." An unsealed writing tells us that no special means are required to make a contract legally binding. Technically speaking, "Envois" are love letters that Derrida supposedly writes to his lover on a whole stock of the same postcard. Commenting on Derrida's text, Richard Rorty says that "nothing is more private than a love letter - there is nothing to which general ideas are less relevant and more inappropriate. Everything, in a love affair or in a love letter, shared private associations" (1989, p. 126). And yet, the most private becomes public, since what is written on a postcard can be read by anyone. "I resemble a messenger from antiquity, a bellboy, a runner, the courier of what we have given one another ... and I run to bring them news which must remain secret, and I fall all the time" (Derrida, 1987, p. 8). Derrida's love written in cipher illustrates his constant and obsessive question: how to save myself (how to save my love) using the only possible language (my proper language) that kills me whenever I open my mouth? Hence, the question is not about how to tell the secret, but just how to write the secret that becomes unspeakable once it takes the shape of words or sentences. Derrida writes as if he were the keeper of his own secret by untiringly trying to tell it. His singular idiom, but also what he often refers to as "unfaithful fidelity" or "the impossible," comes from this secret that must be told to be kept and can never be revealed at the same time. This is why Derrida, as he writes, "fall[s] all the time" (1987, p. 8).

And yet, a fall is not a sine qua non condition of love from a pragmatic perspective. Derrida is fallen in love, but his fall is rather a way of reasoning through writing. If Derrida had been Flaubert, he might have said: "la différance, c'est moi." In fact, the public secret his 
love speaks through is a way of telling the différance he seems to embody and identify with. One may imagine Derrida speaking in these simplified terms: if you want to follow me and see my love, just love the différance, find me disseminated in my love letters. Love, as différance, "cannot be exposed . . . In every exposition it would be exposed to disappearing as disappearance. It would risk appearing: disappearing” (Derrida, 1982, pp. 5-6). Derrida in love is still the one who writes out his fundamental concept and multiplies his masks. Driven by a real love affair, love is also a result of philosophizing.

As Richard Rorty points out, "anybody who has read a little of philosophy will get little from 'Envois"' (1989, pp. 133-134). And yet, if we look at "the incredible richness of texture of 'Envois' - a richness achieved by few other contemporary writers, and no other contemporary philosophy professors" (p. 129) — paying more attention to how Derrida decides to tell his secret love, then "Envois" lets us understand better the autobiographical ghost that haunts his philosophy since his first writings. Telling his love, exposing to the public view what "cannot be exposed" (Derrida, 1982), Derrida certainly exposes himself. However, by his personal exposure and the way he combines "the privately erotic and the publicly philosophical” (Rorty, 1989, p. 127), he also exposes his own concepts.

Derrida's love may be seen as a key to the reinterpretation of his most recognized and apparently more philosophical texts. Suffice it to remember his comment on Phaedrus. In this Platonic dialogue Socrates holds a discussion with the young Phaedrus who reads the text of a sophist speech about love, delivered by Lysias. An exchange on love entails Derrida's argument about the nature of writing that Socrates defines as pharmakon (Derrida, 1981, pp. 61-171). Plato and Socrates make their unexpected return in "Envois." The back of the postcard on which Derrida writes his love letters presents a reproduction of a medieval illustration by Matthew Paris. It depicts Socrates who is writing and Plato who is standing behind. Confessing that "[he] still do[es] not know how to see what there is to see" (Derrida, 1987, p. 16), Derrida endlessly ponders on Paris's illustration and gives the most astonishing interpretations of it through the letters he sends. Identifying with Nietzsche, who describes himself in his letter to Malvida von Meysenbug as "the most offensive [the most scabrous] philologist of the present day" (Derrida, 1979, pp. 34-35), Derrida also seems to identify his love with Paris's illustration. He strangely becomes Plato from his own fantasy:

for the moment, myself, I tell you I see Plato getting an erection in Socrates' back and see the insane hubris of his prick, an interminable, disproportionate erection traversing Paris's head like a single idea and then the copyist's chair, before slowly sliding, still warm, under Socrates' right leg, in harmony or symphony with the movement of his phallus sheaf, the points, plumes, pens, fingers, nails, and grattoirs, the very pencil boxes which address themselves in the same direction. The di-rection, the dierection of this couple, these old nuts, these rascals on horseback, this is us. (Derrida, 1987, p. 18) 
Telling love by unsealed writing, Derrida's lips are definitely not to be sealed, while the secret is not to be hidden, but rather seems to be told in a cryptic language. By recalling the Hebrew meaning of the word "tongue" in the Tower of Babel story, Derrida refers this cryptic language to "one lip, one alone to say everything":

They wanted to elevate sublimely themselves, in order to impose their lip, the unique lip, on the universe. Babel, the father, giving his name of confusion, multiplied the lips and this is why we are separated and that right now I am dying, dying to kiss you with our lip the only one I want to hear. $(1987$, p. 9)

If Derrida's postal principle comes from the fact that "a letter can always not arrive at its destination" (1987, p. 33), his love principle, so to speak, simply comes from the act of writing. Derrida does not write to say je t'aime, even though he is in love. Je t'aime is replaced by je t'écris, which is meant to be understood as "I am writing to you" and "I am writing you" as well. To love is to write: "At every moment the order to write you is given, no matter what, but to write you, and I love, and this is how I recognize that I love" (1987, p. 10). To love is then not necessarily to love the other, but rather to dwell in/on the self and its own love. Saying "I love," saying it again and again in a narcissistic suspense, has the edge over saying "I love you."

And when I call you my love, my love, is it you I am calling or my love? You, my love, is it you I thereby name, is it to you I address myself? I don't know if the question is well put, it frightens me. But I am sure that the answer, if it gets to me one day, will have come to me from you. You alone, my love, you alone will have known it. . . .

when I call you my love, is it that I am calling you, yourself, or is it that I am telling my love? and when I tell you my love, is it that I am declaring my love to you or indeed that I am telling you, yourself, my love, and that you are my love. I want so much to tell you. (Derrida, 1987, p. 8)

When writing "Envois," Derrida seems to have assimilated Sandor Ferenczi's theory he became familiar with through Nicolas Abraham and Maria Torok's works. According to Ferenczi, quoted by Derrida in his preface to The Wolf Man's Magic World, written in 1976, "all object-love [is] an enlargement of the Self" (Derrida, 1986, p. xvi). Torok and Abraham's reinterpretation of the Wolf Man's diary largely determined Derrida's approach to psychoanalysis and his reading of Freud and Lacan in the subsequent chapters of The Post Card. But it may have also fed lines to him when he was performing his love on philosophical stage. Derrida seems to be particularly seduced by the linguistic entanglement of the Wolf Man's case as described by Freud. Abraham and Torok point out that Sergei Pankejeff's personal story was predetermined by four languages. Russian, German, English and French words interacted with each other and created a specific verbarium that one cannot symbolize or refer to an extralinguistic event. The verbarium is a "crypt" that only hides words to be ciphered in a widely open and a fully available text. Words are given, yet they remain out of reach. They are full of phantoms, phonetic, rhyming and semantic fossils, while infinitely switching from one language to another. However, this "jigsaw puzzle" (Abraham \& Torok, 1986, p. 80) does not lead to the hidden meaning which is somehow drowned in the unconscious as if it were buried into the crypt. Abraham 
and Torok speak of "a false Unconsciousness" understood as "the crypt in the Ego-a false 'return of the repressed,' the action in the Ego of hidden thoughts from the crypt" (1986, p. lxxi). What is at stake here is not to provide sense, i.e. to say what the puzzle really means, once it has been assembled. It is rather about discovering the intersymbolic principle which is responsible for the production of cryptonyms with no intention to conclude whether they refer to what is real or imagined.

When telling his love, Derrida speaks from within the crypt. He seems to create a specific love cryptogram in the wake of what he referred to as dissemination in his early writings. To become disseminated would be to "lose one's head, no longer to know where one's head is" (Derrida, 1981, p. 20). Thus, when Derrida says: on va pouvoir enfin s'aimer [we are finally going to love each other], it should be also understood as on va pouvoir semer [we are finally going to spread or disseminate]. Were we to play with homonymy that dissemination feeds on, we may say that a reader sews what Derrida sows through his text from within his crypt (Johnson, 1981, p. xix). However, such a reading is not about sewing Derrida up, stitching him together, but rather about sewing Derrida's private crypt onto his philosophical concepts in order to better understand the link between his philosophy and autobiography. Derrida's crypt is perhaps the most visible/hidden through the way he decides to sign his text by disseminating his name within his writing:

I accept [j'accepte], this will be my signature henceforth, ... take this word at its most literal, it is my name, that $j$ 'accepte, and you will be able to count, to count on it as on the capital clarities, from you I accept everything. (1987, p. 26)

In $j$ 'accepte one is supposed to find Jacques and sept [seven] referring to the number of letters the name Derrida consists of (Bass, 1987, p. xiv). Derrida's corpus is Derrida's body [corps]. However, it would be hard to say that his writing is corporeal. Derrida does not write with or on his own body. He rather writes over his dead body. Singing his text, he accepts his death, yet the signature becomes the only possibility of an impossible life in his corpus - his second skin. For this reason Derrida's love can only exist when enunciating itself; it is both performative and self-centred.

Accepting such a love seems to be rather challenging for the one who is supposed to be loved and somehow despairing for the one who loves. While the former can simply misunderstand the words of love or find no trace of it in the letters she receives, the latter experiences his love as "a tragedy ... of destination" (Derrida, 1987, p. 23):

a tragedy, my love, of destination. Everything becomes a postcard once more, legible for the other, even if he understands nothing about it. And if he understands nothing, certain for the moment of the contrary, it might always arrive for you, for you too, to understand nothing, and therefore for me, and therefore not to arrive, I mean at its destination. (Derrida, 1987, p. 23)

Derrida also notes: 'You always accuse me of being 'delirious,' and you know very well, alas, what that means in our code" $(1987$, p. 17). Of course, no one knows the code that she is supposed to know. It is possible, however, to indicate a specific code of love in Derrida's text. An attempt to decode it would entail leaving Derrida in his crypt and paying attention to his "love delirium" which may be seen as coessential with the language created by the 
"original words" (Abraham \& Torok, 1986, p. 83) from the Wolf Man's crypt. Paradoxically, the crypt makes it possible to see "the truth" of love, yet this love is experienced as real and imagined or fantasized at the same time. A biographical approach to "Envois" cannot be thus limited to what really happened to Derrida, since he decides to immediately hide his love into the crypt. Loving in the crypt becomes a peculiar way of life through writing which skilfully plays with the truth, be it quite a sophisticated form of living a lie. In this respect, Derrida's lecture on Nietzsche from 1972, where writing is identified with "a woman (truth) [who] will not be pinned down" (1979, pp. 55-57), gives us an insight into how Derrida likes to hide in his oeuvre: "a 'woman' takes so little interest in truth, because in fact she barely even believes in it, the truth, as regards her, does not concern her in the least" (1979, p. 63). Only from this perspective may his style be qualified as feminine, yet this perspective tells us nothing about women without inverted commas. This "woman" refers to no other than Derrida who tries to make his love speak through philosophy.

In his famous Literary Theory Jonathan Culler, when explaining why a text can be defined as a literary text in our culture, provides us with a couplet from Robert Frost's poem: "We dance round in a ring and suppose / But the Secret sits in the middle and knows" (1997, p. 22). Any attempt to reveal the secret of "Envois," i.e. to take hold of the text, is certainly doomed to failure. In fact, as Rorty has it, "Envois" is a kind of prose "in which you can never tell, from line to line, whether you are supposed to pay attention to the 'symbolic' or the 'material' features of the words being used" (1989, p. 135). Does it then mean that "there is nothing propositional to be taken away from the experience of reading it" (Rorty, 1989, p. 135)? I would not say so. In fact, if we pay more attention to the material conditions of Derrida's writing and take account of his countless strategies of performing the self on philosophical stage, it becomes possible to find a specific code behind Derrida's verbarium and, as a result, to decode Derrida's cryptic love. However, it is not about trying to force his crypt in order to know the secret. It is rather about observing "the cryptonymic procedure" (Abraham \& Torok, 1986, p. 20) in order to understand what J'accepte means when telling love and signing his love cards: "make myself illegible for you. J'accepte" (Derrida, 1987, p. 34). Understanding Derrida and his love is a complex operation, as it challenges our ordinary ways of understanding things. What is at stake here is not to understand what is hidden behind. There is nothing to be disclosed in Derrida's text since the secret is told. To understand Derrida is not to catch or seize him, to hold together all words his corpus consists of, as the Latin formula of understanding [comprehension] would suggest. To understand the secret is rather to carefully follow the topography of its traces: "I'm talking about conscious secrets, carried by what is known, as known, and not about the unconscious one, no one has yet said anything about the secret as known" (Derrida, 1993, p. 78).

\section{Acknowledgements}

This article is part of a research project "In the Name of Friendship, for the Sake of Community: Friendship and Community in Contemporary French Thought," financed by the National Science Center (NCN), Poland. No. 2015/17/D/HS2/00512 (Sonata). 


\section{References}

Abraham, N., \& Torok, M. (1986). The Wolf Man's magic world: A cryptonymy. (N. T. Rand, Trans.). Minneapolis: University of Minnesota Press.

Bass, A. (1987). Translator's introduction: L before K. In J. Derrida. The postcard: From Socrates to Freud and beyond (pp. vii-xii). (A. Bass, Trans.). Chicago, IL: University of Chicago Press.

Culler, J. (1997). Literary theory: A very short introduction. Oxford, UK: Oxford University Press.

Derrida, J. (1994). Specters of Marx: The state of the debt, the work of mourning and the new international. (P. Kamuf, Trans.). New York, NY: Routledge.

Derrida, J. (1979). Spurs: Nietzsche's styles. (B. Harlow, Trans.). Chicago, IL: University of Chicago Press.

Derrida, J. (1981). Dissemination. (B. Johnson, Trans.). London, UK: Athlone.

Derrida, J. (1982). Margins of philosophy. (A. Bass, Trans.). Brighton, UK: Harvester.

Derrida, J. (1986). Fors: The Anglish words of Nicolas Abraham and Maria Török. (B. Johnson, Trans.). In N. Abraham \& M. Torok, The Wolf Man's magic world: A cryptonymy (pp. xi-xlviii). (N. T. Rand, Trans.). Minneapolis: University of Minnesota Press.

Derrida, J. (1987). The postcard: From Socrates to Freud and beyond. (A. Bass, Trans.). Chicago, IL: University of Chicago Press.

Derrida, J. (1989). Edmund Husserl's Origin of Geometry: An introduction. (J. P. Leavey, Jr., Trans.). Lincoln: University of Nebraska Press.

Derrida, J. (1992a). The other heading: Reflections on today's Europe. (P.-A. Brault \& M. B. Naas, Trans.). Bloomington: Indiana University Press.

Derrida, J. (1992b). Points de suspension. Paris, France: Galilée.

Derrida, J. (1993). Circumfession. In G. Bennington \& J. Derrida, Jacques Derrida (pp. 3-315). (G. Bennington, Trans.). Chicago, IL: University of Chicago Press.

Derrida, J. (2002). Faith and knowledge. (S. Weber, Trans.). In G. Anidjar (Ed.), Acts of religion: Jacques Derrida (pp. 40-101). New York, NY: Routledge.

Derrida, J. (2007). Learning to live finally: The last interview. (P.-A. Brault \& M. Naas, Trans.). Basingstoke, UK: Palgrave Macmillan.

Derrida, J., \& Ferraris, M. (2002). A taste for the secret. (G. Donis, Trans.). Cambridge, UK: Polity.

Dick, K., \& Ziering Kofman, A. (2005). Derrida: Screenplay and essays on the film. Manchester, UK: Manchester University Press.

Feder, E. K., \& Zakin, E. (1997). Flirting with the truth. In E. K. Feder, M. C. Rawlinson, \& E. Zakin, (Eds.), Derrida and feminism: Recasting the question of woman (pp. 21-53). New York, NY: Routledge.

Ferenczi, S. (2002). First contributions to the psycho-analysis. (E. Jones, Trans.). London, UK: Karnac.

Johnson, B. (1981). Translator's Introduction. In J. Derrida, Dissemination (pp. vii-xxxiii). (B. Johnson, Trans.). London, UK: Athlone. 
Nietzsche, F. (2001). The gay science. (J. Nauckhoff, Trans.). New York, NY: Cambridge University Press.

Nietzsche, F. (2007). Ecce homo. (D. Large, Trans.). Oxford, UK: Oxford University Press.

Peeters, B. (2010). Derrida. Paris, France: Flammarion.

Rorty, R. (1989). Contingency, irony, solidarity. New York, NY: Cambridge University Press.

Williams, B. (2001). Introduction. In F. Nietzsche, The gay science (pp. vii-xxii). (J. Nauckhoff, Trans.). New York, NY: Cambridge University Press. 


\title{
"The Art of Writing Posthumous Papers": Kierkegaard and the Spectral Audience
}

\author{
Juan Evaristo Valls Boix \\ University of Barcelona \\ Valls-boix.j.e@ub.edu \\ Received 6 March 2017; accepted 2 October 2017.
}

\begin{abstract}
The aim of this article is to develop a postmetaphysical conception of reading by following Kierkegaard's Either/Or Part I (1843) through such Derridian concepts as secret, hospitality, and spectrality. The work focuses on the three essays addressed to the Symparanekromenoi ("the community of the dead"), a fellowship neither young nor old with an aphoristic way of life (2010b, pp. 137-225) that can be understood as a figure of alterity. Special attention is paid to paratextual features of the book: the texts are actually presented as old papers found in a secretary desk by a pseudonymous editor ("Victor Eremita"), which suggests that every text is a posthumous paper, that is to say, it will always be read after the death of its author. Instead of finding a solid author who holds the semantic weight of the text, these papers are based in a blank of sense, a specter, a secret: if they are sustained on its author, then they are sustained in a mystery, not in a sort of revelation of meaning.
\end{abstract}

Keywords: Kierkegaard; specter; alterity; metaphysics of reading; author.

When Walter Benjamin wrote about Kafka as a storyteller, he stated that good stories are like those seeds of grain that have lain for centuries in the chambers of the pyramids (2007, p. 90). Despite the passage of time, both stories and seeds of grain retain their germinative power, and they can grow endlessly in the most diverse lands and fields. Derrida pointed out something similar when he argued that the " $a$ " of différance remains always silent, secret, and discreet as a grave, or when he considered that, according to Hegel, the signifier's body was also a sort of grave (1972, pp. 4, 95). Lastly, Freud observed in Civilization and its Discontents that "writing was in its origin the voice of an absent person" (2010, p. 18). This persistent link between textuality and death seems to suggest that the best way to approach a literary work is from a distance and after time has exerted its cold expropriation. 
Why do these thinkers link language and literature with a sort of "economy of death" (Derrida, 1974, p. 95)? Why is textuality related to pyramids, graves, absence, and other kinds of distance? Barthes (1998) and Foucault (1969) classically sentenced the death of the author as the end of biography and intentionality as semantic keys for understanding and interpretation, but after this symbolic murder there is still a grave that remains a paradoxical source of meaning: a grave that can be read, or a text that can only be read as a grave, even if this also implies that, far from being a transparent expression of authorial intentions and vouloir-dires, the text can never be fully read or understood. But then, what is inside a textual grave? To what corpse does a textual grave belong?

The aim of this study is to reflect on these questions through Kierkegaard's texts devoted to the Symparanekromenoi ("the community of the dead"), which are included in the first part of Either/Or (Kierkegaard, 1988, 2010b, pp. 137-225). These texts were published under the pseudonym of Victor Eremita, the main character in Either/Or's preface but also the one who plays the role of the editor of the fragments. ${ }^{1}$ The fragmentary texts, which have just been found in a second-hand writing desk, do not have an identified author, and in them Kierkegaard indirectly states that "in a certain sense everything a poet has produced is something left behind" (1988, p. 152; 2010b, p. 151). Could it be said that all texts, or at least all literary texts, come from a forgotten desk - their bureaucratic grave, so to speak?

\section{Empty Graves of Sorrow}

Il n'y a pas de passion sans secret, ce secret-ci, mais pas de secret sans cette passion. Au lieu du secret: là où pourtant tout est dit et où le reste n'est rien—que le reste, pas même de la littérature. (Derrida, 1999, p. 64)

I will focus on the fragmentary texts "Shadowgraphs" and "The Unhappiest One" (Kierkegaard, 1988, pp. 165-230; 2010b, pp. 163-225), two speeches or discourses delivered before the already-dead. Before I start, however, I would like to clearly distinguish between the authorial strategy and the textual play Kierkegaard develops in these earlier pieces and the overall textuality of Kierkegaard's corpus. The richness of Kierkegaard's oeuvre lies in the polyphony of his invented authors - to invoke Mikhail Bakhtin's terminology $y^{2}$ - and in the diversity of textual strategies he employs to disrupt the metaphysical order of idealism and the rise of Hegelianism as a Christian theology, among other purposes. The claims I will make in the following pages concern only one of these many strategies deployed by Kierkegaard at the beginning of his philosophical career, and they should not be understood as general statements about the whole of Kierkegaard's corpus. The relevance of Kierkegaard in philosophy and literary theory stems precisely from his resistance to such kind of overall assertions.

\footnotetext{
${ }^{1}$ For a detailed commentary of the pseudonym "Victor Eremita," see Hernandez-Dispaux's contribution to Stewart \& Nun (2015).

${ }^{2}$ See Pattison (2006) for a detailed approach to Kierkegaard's thought from the perspective of Bakhtin's theories.
} 
In Either/Or Part I, the first of the texts mentioned above, "Shadowgraphs," is on sorrow, a particular version of melancholia. The essential quality of sorrow is its lack of repose, its continuous movement. While other feelings such as joy remain solid and quiet, sorrowor, to be precise, "reflective sorrow" (Kierkegaard, 1988, p. 171; 2010b, p. 165) - is constantly changing and it differs from itself. The observer can only notice the disappearance of sorrow, since its nature is "to pass by" (1988, p. 175; 2010b, p. 173). Such instability disrupts the distinction between presence and absence, and sorrow always "stands" in between, inhabiting the very margins of the distinction. Maybe it is this that makes the representation of sorrow impossible: "this sorrow cannot be depicted artistically, for the interior and the exterior are out of balance, and thus it does not lie within spatial categories" (1988, p. 171; 2010b, p. 165). But its spatial ambivalence is not the only reason why sorrow cannot be artistically represented; there is also its temporal character to be considered: it is "never really present but is continually in the process of becoming" (1988, p. 172; 2010b, p. 165).

These qualities show the proximity of reflective sorrow to Derrida's concept of trembling (Derrida, 1999, p. 82ff; 2006, pp. 97-98). According to Derrida, feelings like anxiety, fear, terror, or panic have already begun in trembling (2006, p. 97), and each of them is a different version of it. We should add Kierkegaard's reflective sorrow to that list, since it is a feeling with the very same features: like trembling, reflective sorrow is an experience of not-knowing, a movement in darkness that generates non-determination and ambivalence, breaking solid distinctions, disrupting limits, and questioning the logics of presence. Reflective sorrow is, like trembling, an experience of secret (Derrida, 2006, p. 98), the experience that shows that identity is always haunted by shadows of alterity and uncertainty.

Its lack of constitution and entity makes sorrow non-representable and unsayable. While joy is "communicative, sociable, and open," sorrow is "silent, solitary" (Kierkegaard, 1988, p. 169; 2010b, p. 165). If speech discusses sorrow, it does so only indirectly, in an oblique way and through reflexes. Sorrow calls into question the very capability of language to communicate, but it does not challenge it in the sense in which absolute absence would: sorrow challenges communication because it involves secrecy. Unlike communication and noncommunication or presence and absence, sorrow and joy are not binarily opposed, but have a more complex relationship: while joy does belong to the binary distinction sayable/unsayable, sorrow does not really fit in either of these categories, but in both at the same time: it is characterized by a lack of repose, by a fluctuation that blurs binary oppositions. ${ }^{3}$ Sorrow is a marginal or differing feeling that makes discourse tremble. It can only be grasped fragmentarily or ironically. It haunts language, disturbing our confidence in words as meaning-carriers, and it challenges the metaphysical entireness of discourse. A word of sorrow does not mean anything, but it cannot help meaning something either: it speaks

\footnotetext{
${ }^{3}$ In this respect, I do not agree with Strawser when he states that "silence, then, is the absolute beginning. . . f for Kierkegaard it is the absolute beginning of the communication of that meaning which is essentially related to existence" (Strawser, 2006, p. 56). The detailed description of reflective sorrow points out that the origin of existential "communication" is not the full absence of silence, but a ruined silence, a silence full of shadows.
} 
without speaking, not thanks to light, but to shadows. Its fecundity lies in its indeterminacy, in its resistance to light and to full manifestation. Like Derrida's experience of secret, reflective sorrow

reste inviolable même quand on croit l'avoir révélé. . . . il excède le jeu du voilement/dévoilement. . . . Il n'appartient donc pas à la vérité, ni à la vérité comme homoiosis ou adéquation, ni à la vérité comme mémoire. . . Sa non-phénoménalité est sans rapport, même négatif, avec la phénoménalité. Il reste étranger à la parole, sans même qu'on puisse dire, syntagme distingué, "le secret, c'est ce qui est, dans la parole, étranger à la parole." (Derrida, 1999, p. 60)

When Kierkegaard (indirectly) claims that reflective sorrow is solitary, he is pointing at this very critique of the logics of manifestation which Derrida develops through the concept of secret. According to Caputo,

this secret-which is sans savoir and non-savoir-has no semantic content. This secret has nothing to hide. This is an odd sort of a secret, something of a non-secret, the secret that there is no secret in the sense of some sort of secret knowledge, some secret knowing, some positive content. $(1997$, p. 107)

Kierkegaard (1992, p. 324ff; 2010a, p. 352ff) would call this kind of discourse "irony," as would Derrida (1999, p. 86), since it is a language deprived of a message, a word that has nothing to say or manifest directly. Consistent with the above, the speaker of this paradoxical speech refers to it as "shadowgraphs" or "silhouettes" [skyggerids]:

It is this reflective sorrow that I aim to single out and, as far as possible, have emerged in a few pictures. I call them silhouettes, partly to suggest at once by the name that I draw them from the dark side of life and partly because, like silhouettes, they are not immediately visible. If I pick up a silhouette, I have no impression of it, cannot arrive at an actual conception of it; only when I hold it up toward the wall and do not look at it directly but at what appears on the wall, only then do I see it. (Kierkegaard, 1988, pp. 172-173; 2010b, p. 171)

Sorrow can then only be depicted through non-depiction and non-manifestation: it is seen thanks to darkness and contrast. Expressions of sorrow, then, are just an announcement: the "telegraphic report" (Kierkegaard, 1988, p. 173; 2010b, p. 172) that there is something hidden that cannot be apprehended, but only reflected, suggested, insinuated. Sorrow transforms discourse into a space of secret and oblique light and darkness; it states that words do not possess a definite meaning for us to disclose as a treasure in a chamber, but that they are always fragmentary and excessive or insufficient, since they always try to capture a tremble. While Hegel's systematic works always include a section on unhappy consciousness (1988, p. 222; 2010b, pp. 215-216), in which sorrow is controlled and explained, the discourse before the already-dead is a fragment, a silhouette, an impossible word. Kierkegaard makes of textuality a space of experience, dark pleasure, secret, and sorrow. Sorrow is not meant: it is the spectre that haunts the text and makes it tremble.

\footnotetext{
${ }^{4}$ For a more detailed description, see Caputo (1995) as well. These observations are contained in the etymology of "secret," which means "to put at distance, set apart," as Llewelyn reminds us (2008, p. 37).
} 
Words of sorrow are not like a chamber containing a treasure of meaning, but, in a similar way to Benjamin's stories or Derrida's différance, they might resemble an empty grave. That is what is suggested by the speech "The Unhappiest One," which takes its title from the inscription on the tombstone that the community of the already-dead is talking about. It is from a grave in England that was opened, but in which no trace of a corpse was found. And so this question arises: who will be the unhappiest on earth? To whom does the English grave belong? The unhappiest one is the carrier of the greatest and darkest sorrow, and has the same confusing qualities. First, he is neither alive nor dead: "in a sense he cannot die, for indeed he has not lived; in a sense he cannot live, for indeed he is already dead" (Kierkegaard, 1988, p. 227; 2010b, p. 213). Secondly, like sorrow itself, he is always absent from himself, and at the same time never present to himself: the "substance of his life" is always "outside himself" (1988, p. 227; 2010b, p. 214), distant and differed, and he is always in the tense process of becoming. In consequence, "why the grave was empty could be explained - namely, to indicate that the unhappiest one was the person who could not die" (1988, p. 226; 2010b, p. 220). Sorrow and unhappiness are the source of spectres and phantoms. As long as there is sorrow in the world, spectres and phantoms will haunt it, and graves will be empty. That is why Kierkegaard's sorrow shares its indeterminacy with Derrida's spectre:

le spectre est une incorporation paradoxale, le devenir-corps, une certaine forme phénoménale et charnelle de l'esprit. Il devient plutôt quelque « chose » qu'il reste difficile de nommer : ni âme ni corps, et l'une et l'autre. Car la chair et la phénoménalité, voilà ce qui donne à l'esprit son apparition spectrale, mais disparaît aussitôt dans l'apparition, dans la venue même du revenant ou le retour du spectre. Il y a du disparu dans l'apparition même comme réapparition du disparu. (Derrida, 1993, p. 26)

But the interest of sorrow lies in the connection between the empty graves and language, a connection made through the fragmentary textuality of the already-dead's discourses. The same inscription announcing the greatest sorrow is the law of the text - the title - and the inscription on the grave. The text is the grave, announcing its distance, its differing, its incommunication, and its indirect meaning. What the Symparanekromenoi are asking themselves is to whom a text belongs, since it is like a grave dedicated to the unhappiest one. But the text-grave refuses all appropriation, and it keeps waiting for the unhappiest. Its inscription challenges every reader to ask themselves whether they carry the heaviest sorrow and whether they should occupy the empty grave. But in this sense, it never belongs to anyone. There is no place for property in a text.

The text itself proclaims that there is nothing to be said, that words cannot be trusted any more as messengers of a particular truth or sense, but only as the tombstones of empty graves, as announcers of spectres:

See, language breaks down, and thought is confused, for who indeed is the happiest but the unhappiest and who the unhappiest but the happiest, and what is life but madness, and faith but foolishness, and hope but a staving off of the evil day, and love but vinegar in the wound. He disappeared, and we stand again by the empty grave. (Kierkegaard, 1988, p. 230; 2010b, p. 223) 
Sorrow challenges solid distinctions and limitations and introduces its very tremble in them. It shakes the solidity of the text as a keeper of a meaningful spirit. Like a grave, a text is empty, because it does not hold a meaning but a secret, something hidden that can neither be represented nor depicted by art nor said: textuality remains in excess in any representation. What we have is just the name of the text, and its secret: words and words announcing a difference of sense, presence, and life. We can read the text and hear it, but its content (the corpse, the meaning) remains absent. Despite that, words still say something, as does the inscription on the tombstone: they are not absurd. They say something that is never clearly present, though, but is only a shadow. At the same time, then, the textgrave is unreadable - non-accessible - and readable. Like sorrow, its exterior qualities (words, sentences) are completely visible, as are the stone and its inscription, but this is just like a shadowgraph, an empty silhouette, an empty grave.

The text, like the empty grave consecrated to the unhappiest one, belongs to no one and to everybody at the same time. It is readable, but its words only announce a vacuum, or rather a meaning always in the process of becoming, a meaning to come. In this regard, the meaning of the text is not showable or readable, just as the corpse of an empty grave cannot be exhumed. There is no exorcism of meaning in a text, but only the disturbing haunting of spectres. The discourses before the Symparanekromenoi, with their incompleteness and shadows, help to develop a literature of alterity. Textuality is not based on the joy of identities of meaning, communicable and preserved as a present body that is mourned over by the family of the deceased (lovers, widows, publishing houses, university, academia, etc.). The sorrow of a text-like Derrida's différance-introduces the economy of death into language and brings about the end of identity as a source of textual immobility and of interpretation as a process of deciphering. Like an open, empty grave, the text is forever waiting for its addressee.

\section{The Spectral Audience}

Through Kierkegaard's sorrow, which is closely similar to Derrida's différance or spectre, the text loses any dependence on a reference or meaning and becomes an empty grave. This indicates that a text is not the result of the expression of an ideal meaning, but rather that meaning is always an (im)possible and conventional appropriation of a text: spectral and melancholic texts wait for some meaning to come, just as the unhappiest one's empty grave waits forever for its impossible owner. Both are a promise of meaning. The text and the grave are open to everyone, to the wholly other.

But who are the addressees of the speech? What are the Symparanekromenoi like? As the addressees of a speech about sorrow, they are first and foremost a figure of alterity: being beyond death, they avoid all identification or recognition. It is a community based on the desire to come to an end and fully disappear, constituted in the victory of the night: a society that professes the doctrine of the downfall of everything (Kierkegaard, 1988, p. $167 \mathrm{ff} ; 2010$ b, p. 170ff). It is a society of spectres, since the complete and full absence 
of its members is only a desire, or a prayer, but never a reality. Thus, it is a society of dead members, but also the community of those who have never lived, but have always survived. Like reflexive sorrow or a spectre, they lead an aphoristic life:

we who live aphorismos and segregati, as aphorisms in life, without association with men, having no share in their griefs and their joys; we who are not consonants in the clamor of life but are solitary birds in the stillness of night. (Kierkegaard, 1988, p. 220; 2010b, p. 214)

What does all this mean? We usually understand that, even if a text does not have an inherent meaning, its reader will provide it with one by placing it in a particular context. In that sense, we tend to acknowledge the polysemy of a text, and we take into account the reader whom the author had in mind when he wrote the text, that is, we try to determine textual meaning by projecting a reader's profile, and therefore we assess the text according to extratextual factors. Kierkegaard cancels out this metaphysical source by describing the figure of a fragmentary and spectral reader. The addressee is always the other, the wholly other: someone beyond identification, someone simultaneously dead and alive. Being beyond life, it survives after all possible determination or contextualization has taken place. The Symparanekromenoi are then

a society that knows but one passion, namely, sympathy with sorrow's secret. . . . the cheery smiles of happy maidens do not move us, but rather the secret hint of grief. . . Our choice is made: we love only sorrow. We are in quest only of sorrow, and wherever we find its trail, we follow it, fearlessly, unwaveringly, until it discloses itself. (Kierkegaard, 1988, p. 174; 2010b, p. 171)

Two consequences arise from this passage: first, the reader is dismissed as a solid instance or reference for contextualization and meaning and, far from providing a framework for the text, it comes to emphasize its indeterminacy. The Symparanekromenoi are a spectral audience, and to read is to insist on the mystery of an empty grave, to love the trembling of sorrow through words. According to Agacinski, "l'écrit n'a jamais de 'public'. Il prend le lecteur à part, l'isole nécessairement, l'entraîne à l' écart, le convoque à un simulacre de tête-à-tête d'où l'auteur demeure absent: écrire, lire, c'est toujours entrer dans cet aparté" (1977, p. 110).

Secondly, to read is a gesture of passion by which one waits with infinite patience for a meaning to come and for the secret of sorrow to be revealed. Kierkegaard shows us that reading is not about understanding, apprehending, or communicating, but that it is rather a passive activity stimulated by the essential unreadability of the text, that is, by the impossibility of its full translation or its full saturation by meaning (Lisse, 1996, p. 191ff). The reader loves sorrow and the enigma of an empty grave waiting for its corpse. The reader is also calling out and waiting for a meaning that has been promised by the inscription of the text ("the unhappiest one"), but that promise is constantly deferred and never accomplished.

The trembling of sorrow disrupted common notions of space and time: it was neither absent nor present, and it was always in the process of becoming. Derrida called it "the becoming-time of space and the becoming-space of time" (1972, p. 8; 1982, p. 8). Since meaning is subjected to the same displacement, readability and unreadability are no longer 
in opposition. Rather, unreadability is the condition of the possibility of readability (Lisse, 1996, p. 215). Symparanekromenoi are passionate about the secret of sorrow, and it is this not full understanding, this inconclusiveness, that generates the active passivity of reading and turns reading into a kind of writing - a kind of waiting for the unhappiest one. Symparanekromenoi show that reading a text is possible and impossible at the same time, and it is this paradox that transforms every text into irony and into a call for alterity: "I hail you, great unknown, whose name I do not know; I hail you with your title of honor: the unhappiest one. Greetings and salutations from the community of the unhappy to you here in your home" (1988, p. 229; 2010b, p. 222). Like Derrida, Kierkegaard links the unreadability of secret with the infinite passion of reading in order to think literature:

si, sans aimer la littérature en général et pour elle-même, j'aime quelque chose en elle qui ne se réduise surtout pas à quelque qualité esthétique, à quelque source de jouissance formelle, ce serait au lieu du secret. Au lieu d'un secret absolu. Là serait la passion. Il n'y a pas de passion sans secret, ce secret-ci, mais pas de secret sans cette passion. Au lieu du secret : là où pourtant tout est dit et où le reste n'est rien—que le reste, pas même de la littérature. (Derrida, 1999, p. 64)

\section{What's that Voice? The Art of Writing Posthumous Papers}

Having considered the spectrality of the text, and the reader as a figure of alterity-i.e. the spectral audience - it is time to examine where the text comes from, to analyse the "origin" of the text. It is the last element of the metaphysics of reading (author, work, reader) that needs to be called into question.

We could actually think of two origins of the text. The first is fictive and is described and suggested by means of paratextual marks. In this sense, the fragmentary texts were found in the secret drawer of a writing desk bought in an antique shop by their editor, Victor Eremita. If the subtitle indicates that the texts are fragmentary, it is also because they are detached from their origin. They were left behind by someone, separated from the one who wrote them, and compiled - together with other drafts - in a new volume, which works as a collage. The emphasis thus shifts away from the author to distance and elusiveness: from the clarity of identity to the ambivalence of old desks, secret drawers, unknown authors, a mysterious editor (whose name, which means "the victory of the solitary" in Latin, is not exactly an ordinary Danish name), and the fragmentary nature indicated in the subtitle. And if we ask the text directly, we obtain a similar response:

Let us, then, designate our intention as a venture in fragmentary endeavor or the art of writing posthumous [efterladt] papers... . . the art is to evoke an enjoyment that is never present tense but always has an element of the past and thus is present in the past. This is already expressed in the expression "left behind" [efterladt]. Indeed, in a certain sense everything a poet has produced is something left behind [efterladt]. (Kierkegaard, 1988, p. 152; 2010b, p. 152) 
The text refers to itself and states that it is a ruin, and that its origin is ruined as well, lost in the past and erased by time. These assertions stand in tension with the subtitle, which describes the text as a "peroration" (Kierkegaard, 1988, p. 217; 2010b, p. 211) and as a conference, since it is delivered [Forelcest] before the fellowship of the dead (Kierkegaard, 1988 , pp. 165, 217; 2010b, pp. 137, 163). At the same time, the text belongs to a genre that requires full presence and recognition (that of speech, public discourses or conferences), and it is an excerpt left behind, abandoned and feeding on distance. The contradiction of these indirect claims invites us to regard every scene of communication as full of distance, misunderstanding, and the alterity of language. Even if the text, as a peroration or a lecture, is always addressed to someone, we do not know where it comes from, who owned it as its master or its authority, and we do not need to know it to read a text. According to Crépon,

le poème atteste d'abord et avant tout la présence d'une solitude et d'une singularité conjointes (qui sont davantage les siennes propres que celles du poète). Il résiste à toute reconduction à une appartenance quelconque - à toute appartenance qui viendrait entamer ou compromettre sa portée universelle et indéterminée. (as cited in Jdey, 2011, p. 102)

Cohen-Lévinas agrees when she points out that "le poème deviendrait étranger à sa source. Il se soustrairait à elle, se désaccorderait. Il serait une figure de disharmonie, l'intempestivité même de la langue, son risque, sa plainte, ses éclats de rire et ses sanglots" (as cited in Jdey, 2011, p. 116).

The second origin of the text we could identify is its "real" one, so to speak: why did a writer named Kierkegaard decide to compose such a text under the form of such perorations? We can read the following in Kierkegaard's diary:

Precisely I was looking for an expression to designate that kind of people to whom I would like to write, convinced that they will share my conception, and now I have found it in Luciano: paranekroi (one who, like me, is dead), and I would feel like publishing a text for paranekroi. $(1988, \text { p. } 25)^{5}$

The author abandons his position as master and declares himself dead or absent, a member of the fellowship of the dead. Kierkegaard's voice rises from the dead and comes from a city in ruins. It is a voice that keeps speaking independently of its author - a voice without a master, prolonging his words through masks and distances. It is then a spectral voice that paradoxically belongs to a dead author: a written voice that makes an author absent to himself, that confronts the author with something other than himself. In Delecroix' words,

l'écriture se déploie dans la contestation de la pleine présence de l'être. Ses signes naissent de l'introduction d'une différence qui diffère l'immédiat rapport de soi à soi de l'être plein.... on pourrait dire que le geste qui chez Kierkegaard lie l'écriture au devenir atteste une double contestation similaire : celle de l'identité à soi (de l'être) et de son corollaire, à avoir la présence à soi (du sujet). (2009, p. 444)

\footnotetext{
${ }^{5}$ For further reading about Kierkegaard's interruption of the continuity between the author and its philosophical "I" through writing, see Garff (2003). In addition, Watkin (1993) offers an interesting analysis of the denegation of authority and the critique of authorship in Kierkegaard's early works.
} 
And he adds: "être absent à soi-même, c'est ainsi le mal, structurel, d'où naît l'écriture ; devenir présent à soi-même, par elle, c'est l'horizon paradoxal de la tâche d'écrire, paradoxal au plus haut point puisque l'écriture creuse d'abord cette absence" (2009, p. 448). The text embodies a voice, but this voice is continuously losing the sonority and the light of the logos.

Without a Father, textuality is no longer a Son: it embodies an "impossible filiation" (Derrida, 1999, p. 85ff). But this absence of Father is linked as well with the absence of a concrete and determinate addressee. If the audience is composed of spectres, of dead listeners, and there is not a solid identity that can be singled out as the voice of the text, then there is no world in common, no idea of community or identity that is shared by the text and the reader, and therefore meaning is destabilized and interrupted. This radical independence gives the reader the opportunity of becoming fully responsible for the text, even when there is no space for family or proximity in it. Distance and alterity give way to ethics of infinite responsibility in textuality. According to Derrida, distance and the absence of a common world are the only source for a responsibility worthy of its name:

Pour être responsable il faut qu'il n'y ait plus de monde. Alors on peut dire : là où il n'y a plus de monde je suis responsable de toi ; ou bien, dès que je suis responsable de toi, et je te porte, à ce moment-là j' anéantis le monde, il n'y a plus de monde, au moment où je suis responsable devant toi le monde disparaît. Pour être vraiment, singulièrement responsable devant la singularité de l'autre, il faut qu'il n'y ait plus de monde. (Derrida, 2006, p. 103) ${ }^{6}$

Kierkegaard is tackling the same question when he breaks all references of the text and replaces them by distances, spectres, and secrets. If the text does not belong to anybody, anyone who wants to read it has to answer for it, and has to do it endlessly.

In sum, both of the text's origins are disturbed by distance, made indeterminate, and ruined by haunting spectres. The text comes from an unknown place, carries an impossible message of sorrow, and flows towards alterity. In Cohen-Lévinas' words,

Avant de dire ou de vouloir dire, le poème appelle, comme demeuré dans un lieu de résonnance qui n'est déjà plus sa langue ni sa voix ni son écoute. C'est sans doute là que résiderait aussi sa singularité non originaire, mais plutôt primitive. (Cohen-Lévinas as cited in Jdey, 2011, p. 114)

Text is, like a meteorite (Derrida, 1999, p. 185), readable and seen only in its impossible manifestation while it crosses the sky of time and travels beyond death. Like a faraway star, it is only perceivable in its mystery. As we read it, it lets us know that there is nothing to read. We are the only carriers of such a bottomless secret, the messengers of the obscurity brought by the glance of the text.

\footnotetext{
${ }^{6}$ For further reading on this topic, see Derrida (2003). In addition, for a more detailed explanation about Kierkegaard and Derrida's ethics of alterity and infinite responsibility, see Llevadot (2013).
} 


\section{Conclusions: Towards a Literature of Alterity}

Kierkegaard challenges the metaphysics of reading and calls into question the unitary character of a work. He becomes a paradoxical heir of Barthes, Foucault, and Derrida, and develops a conception of literature and language based on death and empty graves. His idea of sorrow is very close to Derrida's différance, secret and trembling, and his Symparanekromenoi are the impossible sons of spectres. Like Benjamin, he can be seen as a gravedigger of the Word and of the Aura of meaning (the Presence) (Benjamin, 2007, p. 221), and he is able to demythologize textuality, freeing it from any kind of authority, truth, or determinate structure. By adopting all these strategies, Kierkegaard is developing a literature of alterity, a sense of textuality that avoids any kind of appropriation, referentialism, biographicism, and contextualism, and allows us to discover its singularity and its enigmatic secret. Remaining a ruin, speaking without saying, and haunting like a spectre, literature is a space of dispossession that demarcates the dissolution of all identity. The secret chambers of literary pyramids, then, might be a precious opportunity to think about a literary ethics of alterity and gift. The radical expropriation of ruined texts could be the best chance for hospitality.

\section{Acknowledgements}

This paper has been funded by a pre-doctoral scholarship granted through the "Subprograma de Formación de Profesorado Universitario" (FPU), within the "Programa Estatal de Promoción del Talento y su Empleabilidad" by the Ministerio de Educación, Cultura y Deportes (Spain). I would like to thank Lucía Giordano for helpful comments and corrections on an earlier draft of this paper.

\section{References}

Agacinski, S. (1977). Aparté: Conceptions et morts de Søren Kierkegaard. Paris, France: Aubier.

Barthes, R. (1998). Le bruissement de la langue: Essais critiques IV. Paris, France: Gallimard.

Benjamin, W. (2007). Illuminations: Essays and reflections. New York, NY: Schocken Books.

Caputo, J. D. (1997). The prayers and tears of Jacques Derrida: Religion without religion. Bloomington: Indiana University Press.

Delecroix, V. (2009). Kierkegaard: Etre, écrire, devenir. Revue des Sciences Philosophiques et Théologiques, 93(3), 441-462.

Derrida, J. (1972). Marges de la philosophie. Paris, France: Éditions de Minuit.

Derrida, J. (1974). Of grammatology. (G. Spivak, Trans.). Baltimore, MD: Johns Hopkins University Press.

Derrida, J. (1982). Margins of philosophy. (A. Bass, Trans.). Chicago, IL: Harvester Press.

Derrida, J. (1993). Spectres de Marx. Paris, France: Galilée. 
Derrida, J. (1999). Donner la mort. Paris, France: Galilée.

Derrida, J. (2003). Béliers: Le dialogue ininterrompu: entre deux infinis, le poème. Paris, France: Galilée.

Derrida, J. (2006). Comment ne pas trembler? Annali: Fondazione Europea del Disegno (Fondazione Adami), 2, 91-104.

Foucault, M. (1969). Qu'est-ce qu'un auteur? Société Française de Philosophie, 63(3), 73ff.

Freud, S. (2010). Civilization and its discontents. New York, NY: W. W. Norton \& Company.

Garff, J. (2003). 'What did I find? Not my I': On Kierkegaard's journals and the pseudonymous autobiography. Søren Kierkegaard Yearbook, 2003, 110-124.

Hernandez-Dispaux, J. (2015). Victor Eremita: A diplomatic yet abstruse editor. In J. Stewart \& K. Nun (Eds.), Kierkegaard's pseudonyms: Kierkegaard research: Sources, reception and resources, vol. 17 (pp. 243-257). Farnham: Ashgate.

Jdey, A. (Ed.). (2011). Derrida et la question de l'art: Déconstructions de l'esthétique, suivi d'un entretien inédit avec Jacques Derrida. Paris, France: Éditions Cécile Defaut.

Kierkegaard, S. (1988). Either/Or: Part I. Kierkegaard's Writings, III. Princeton, NJ: Princeton University Press.

Kierkegaard, S. (1992). The concept of irony, with continual reference to Socrates: Notes of Schelling's Berlin lectures: Kierkegaard's writings, II. Princeton, NJ: Princeton University Press.

Kierkegaard, S. (2010a). Søren Kierkegaards Skrifter. Elektronisk version 1.5, ed. Copenhagen, Denmark: Søren Kierkegaard Forskningscenteret. Retrieved from: http://sks.dk/forside/indhold.asp

Kierkegaard, S. (2010b). Søren Kierkegaards Skrifter. Elektronisk version 1.5, ed. Copenhagen, Denmark: Søren Kierkegaard Forskningscenteret. Retrieved from: http://sks.dk/forside/indhold.asp

Lisse, M. (Ed.). (1996). Passions de la littérature: Avec Jacques Derrida. Paris, France: Galilée.

Llevadot, L. (2013). Kierkegaard through Derrida: Toward a postmetaphysical ethics. Aurora, CO: The Davies Group Publishers.

Llevadot, L., \& Revilla, C. (Eds.). (2015). Interpretando Antígona. Barcelona, Spain: Editorial UOC.

Llewelyn, J. (2008). Margins of religions: Between Kierkegaard and Derrida. Bloomington: Indiana University Press.

Pattison, G. (2006). Bakhtin's category of carnival in the interpretation of the writings of Søren Kierkegaard. Kierkegaard Studies Yearbook, 2006, 100-128.

Perkins, R. L. (Ed.). (1995). International Kierkegaard commentary: Either/Or: Part I. Macon, GA: Mercer University Press.

Strawser, M. (2006). Gifts of silence from Kierkegaard and Derrida. Soundings: An Interdisciplinary Journal, 89(1-2), 55-72.

Watkin, J. (1993). The journals and the works of 1843 with particular reference to Either/Or. Tópicos, 5, 19-51. 


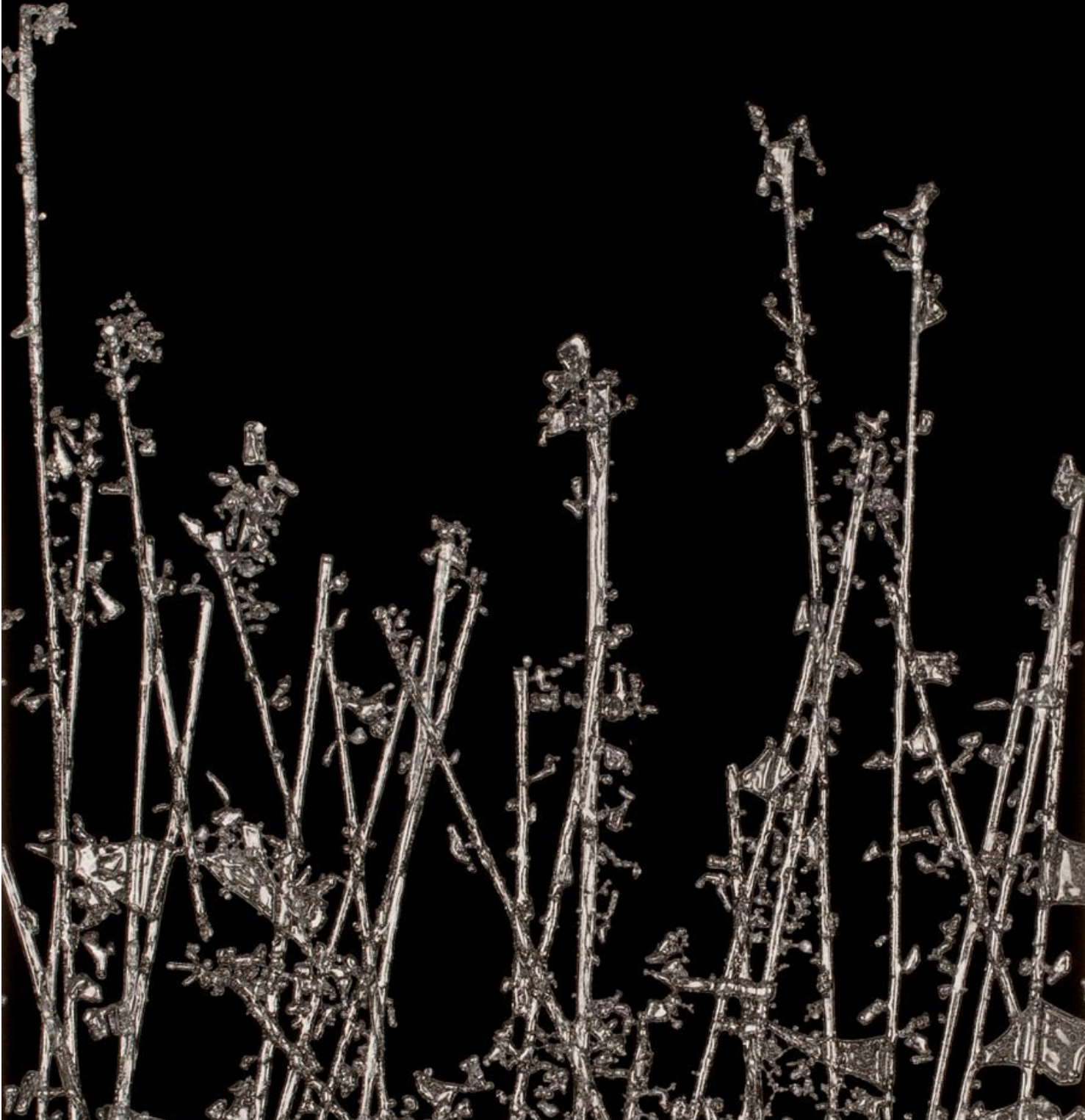

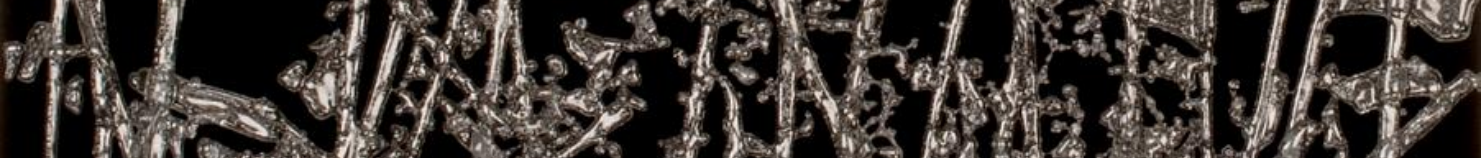
(1)

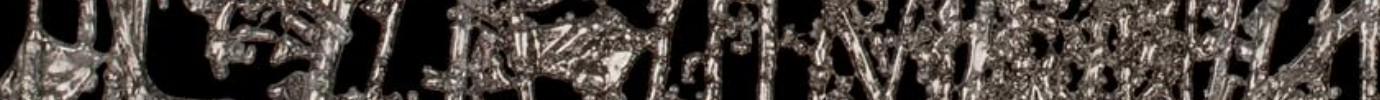

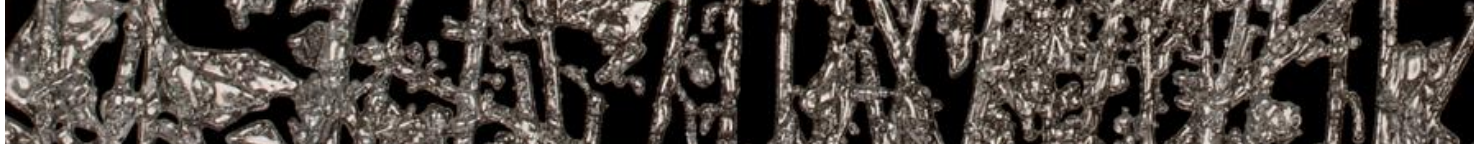

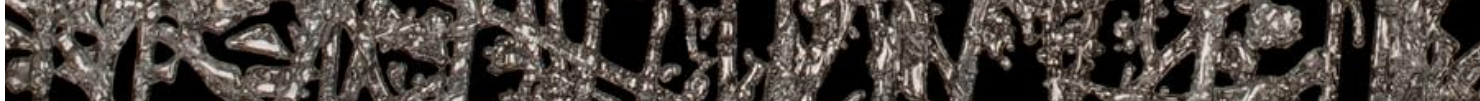

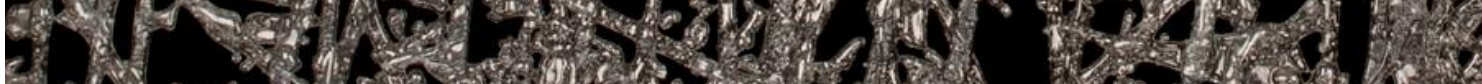

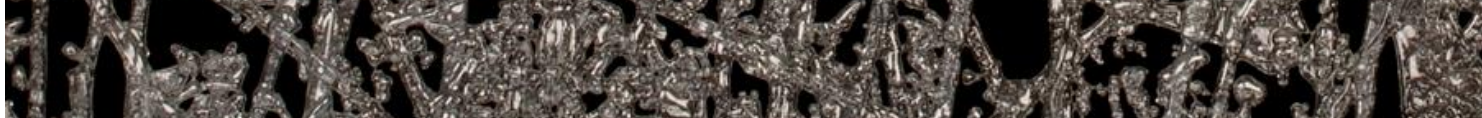

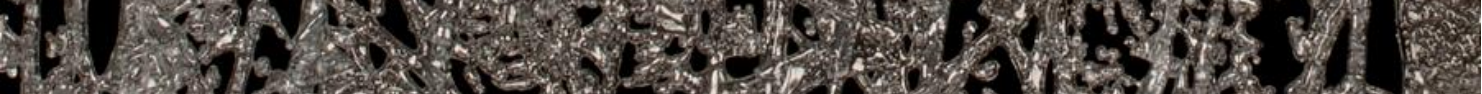

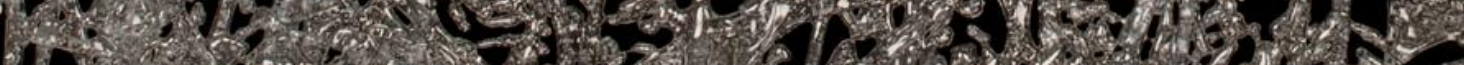

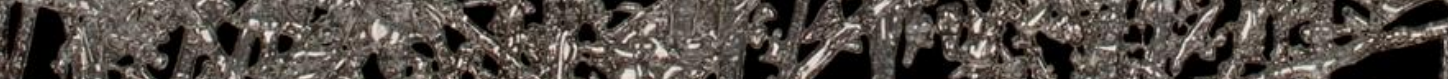

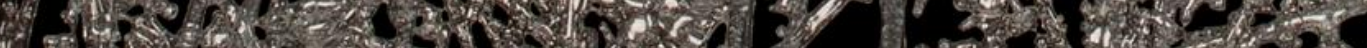
V.

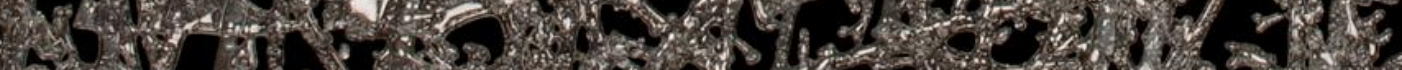

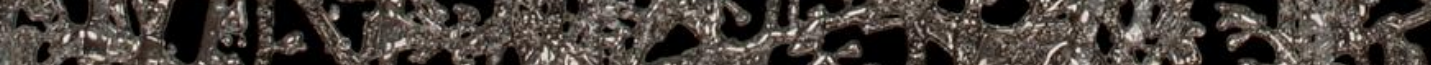

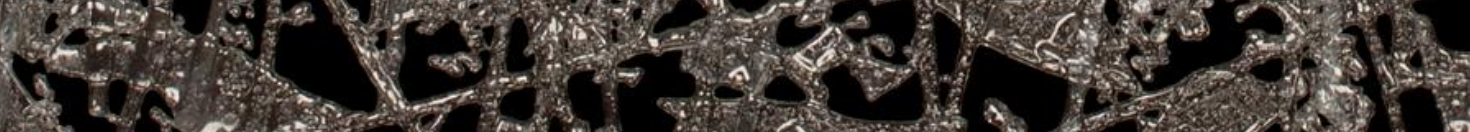

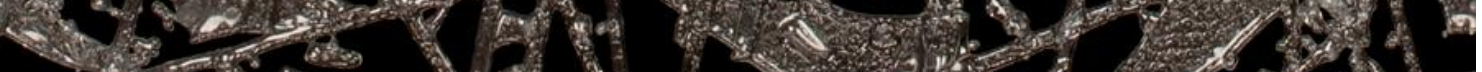


Anna Kola, from the series Landscapes / T-IV, fused glass, 50x80 cm, 2010 


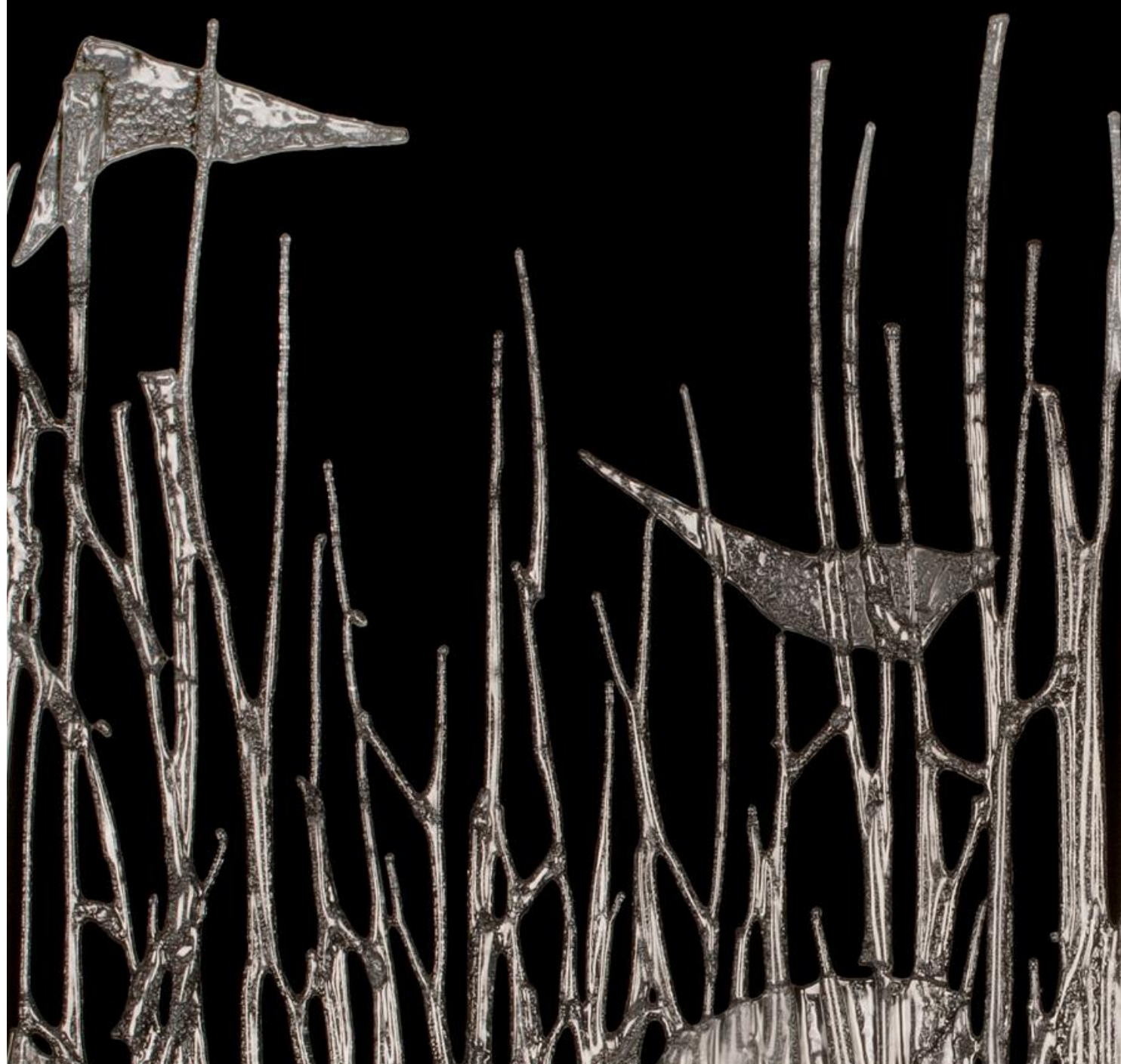

1.4. 4 .

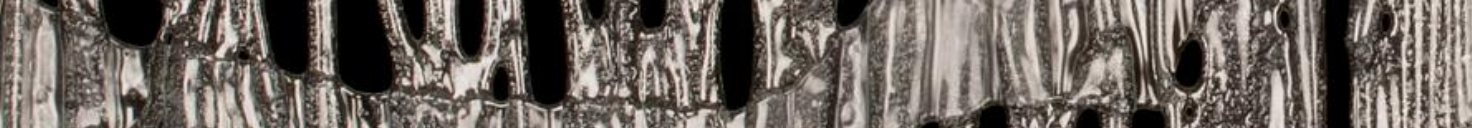
(1.2. $1 .(10)$ (n) a 1.3.

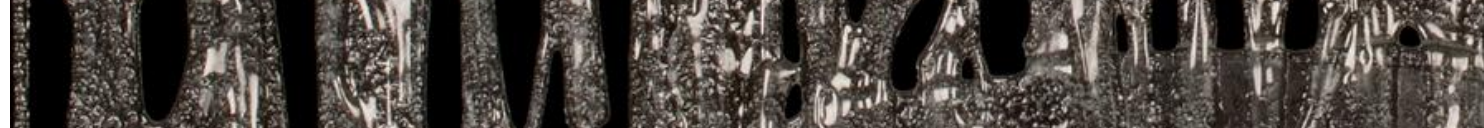

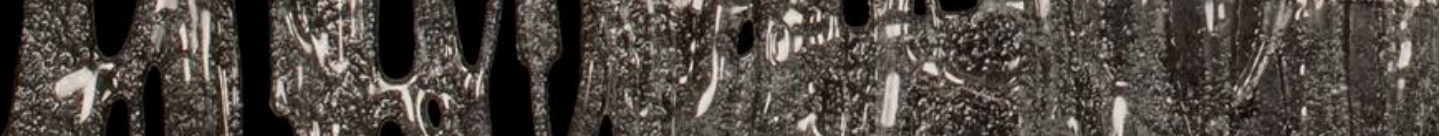

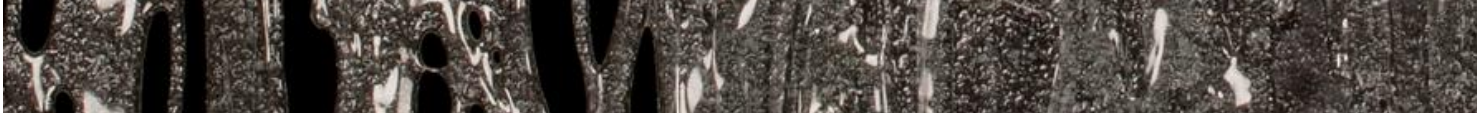

$$
\text { 1. }
$$


Anna Kola, from the series Landscapes / $\boldsymbol{T}$ - $\boldsymbol{V}$, fused glass, 50x80 cm, 2010 


\section{Part Two: Un-burying Ghosts}





\title{
Burial Grounds and Dead Lovers: Places of Interment in the Gothic Modernism of the American South
}

\author{
Arthur Redding \\ York University in Toronto \\ aredding@yorku.ca
}

Received 6 March 2017; accepted 2 October 2017.

\begin{abstract}
In Cities of the Dead, Joseph Roach speculates that "Modernity itself might be understood as a new way of handling (and thinking about) the dead" (1996, p. 48). Roach (following Foucault) argues that a whole array of rationalized spatial practices emerged during the Enlightenment designed to enforce policies of segregation and hygiene, demarcating the social and metaphysical lines that were necessary to distinguish black from white, civilization from nature, citizen from foreigner, past from present, reason from supernatural or folk forms of knowing, and - ultimately - living from dead. In this sense, "gothic" romanticism represented the development of a sort of unnatural chiaroscuro effect, whereby such boundaries and lines of distinction became blurred, where dead flesh becomes re-animated, where corpses risen from graves come to contaminate the spaces of the living. In contradistinction to formations that "view the dead as hermetically sealed off from contemporaneous life, quarantined into the past," gothic cultural productions, as Eric Anderson et al. have argued recently in Undead Souths, reveal "how the dead contain cultural vibrancy in the present" $(2015$, p. 2). This essay, rethinking traditional understandings of "Southern Gothic" by emphasizing the world-making power of the dead, explores texts about burial grounds by modernist writers from the American South, William Faulkner's As I Lay Dying (1930) and Frances Newman's Dead Lovers are Faithful Lovers (1928). En route, I consider Freudian and other understandings of mourning from a spatial perspective, focusing on variously abortive or failed funereal dramas of interment and burial.
\end{abstract}

Keywords: Southern Gothic; corpse bride; modernism; American literature; William Faulkner; Frances Newman. 
We all sleep with the corpses of our dead lovers.

John Dufresne

At the center of the narrative of Faulkner's As I Lay Dying (1930) there is, famously, a gap, a literal hole, a blank, in the text; that hole is the coffin-shaped space of the dead Addie Bundren, a speaking corpse. And not only does this corpse speak, she offers up a theory of language itself, a theory wrought of her own sexual disappointment, her certainty that femininity in general - and motherhood in its cruel particulars - is a trap, wrought too of lust, and sexual infidelity, and terror, and agonizing illness and death. Addie's concept of language has been forged in her bitter confrontation with the hypocrisy and brutality of her husband and others in her family and surrounding community. Addie's is a theory of language that is downright Derridean: a word is "a shape to fill a lack" (Faulkner, 1990, p. 172).

But it is also carnal.

From her coffin, Addie recalls and recounts to us unhappily what occurs between her and her husband "in the nights": "He had a word, too. Love, he called it. But I had been used to words for a long time. I knew that the word was like others: just a shape to fill a lack" (Faulkner, 1990, p. 172). For Addie, such words are empty; language, the language of love, of sexuality, the language of enmity, any language and all languages, are products designed to shield us from a confrontation with the ultimate emptiness that is our own selves. Recalling Shakespeare's Juliet Capulet (another famously dead lover), she meditates on the arbitrariness of her husband's name. The difference from Juliet, of course, is that Addie's feelings run from indifference to contempt:

I would think: Anse. Why Anse. Why are you Anse. I would think about his name until after a while I could see the word as a shape, a vessel, and I would watch him liquefy and flow into it like cold molasses flowing out of darkness into the vessel, until the jar stood full and motionless: a significant shape profoundly without life like an empty doorframe; and then I would think that I had forgotten the name of the jar. (1990, p. 173)

For Addie, "the arbitrariness of the sign" is a problem because of its existential dishonesty, because of its falseness, its deception: language is used not to conceal what is, but what is not; she knows that a word is nothing more than "a shape to fill a lack" because of her body, of her womb, of the emptiness she feels in her marriage: "I would think: the shape of my body where I used to be a virgin is in the shape of a and I couldn't think Anse, couldn't remember Anse" (1990, p. 173).

As those readers who know Faulkner's justly famous fifth novel will remember, the story, told through the voices and perspectives of fifteen different characters, concerns the adventures and perils faced by the Bundren family as they undertake an odyssey to the proper burial grounds of wife and mother, Addie. On their journey, Addie's coffin is threatened by flood and fire. Her body is again violated after death when her troubled youngest son, Vardaman, drills holes in the coffin so that she may breathe. Her mortal remains rot away and she begins to stink; buzzards trail the Bundrens as they bear her corpse across the 
country at the behest of the arrogant, self-pitying, and lazy but stubborn patriarch, Anse. Anse is determined to honor his wife's wishes, to bury her with her own kin, in the county seat, Jefferson. But he has ulterior motives as well, as do all the characters. Addie is, ultimately, buried with a borrowed shovel. Anse, who has stolen his daughter's money (money with which she had hoped to pay for an abortion), obtains a new wife, "a kind of duck-shaped woman all dressed up, with them kind of hardlooking pop eyes like she was daring a man to say nothing" (Faulkner, 1990, p. 260), along with a new set of teeth. With the burial of the first wife, life is, somewhat comically, renewed. The familial and social order, now purged of its contaminating elements - the most troublesome son, Darl, has been confined to the madhouse - is restored. With the proper burial of the dead, the world of the living may be renewed.

What I want to emphasize is the constitutive power of the dead, their capacity to make the world. In particular, I want to stress here two aspects of this constitutive power. First, as Addie has insisted, language is carnal. My stress on the corporeality of the word does not mean that Derrida, in his critique of the metaphysics of presence, is wrong about the priority of writing; it does mean that oral discourse or spirit precedes writing. In Addie's case, it is a dead body that speaks, not a living one. Second, Faulkner is teaching us that mourning (whether it be resolved or not) is not simply a psychic process, even in so-called modern societies. Mourning is geographic; it is carried out as a distinctly spatial practice that involves bearing the dead to her or his "rightful" burial grounds.

To briefly elaborate, in Cities of the Dead, Joseph Roach (1996) speculates that "Modernity itself might be understood as a new way of handling (and thinking about) the dead" (p. 48). Roach (following Foucault) argues that a whole array of rationalized spatial practices emerged during the Enlightenment that were designed to enforce policies of segregation and hygiene. Central to the project of constructing modernity, orchestrated burials and the rationalized mapping and planning of graveyards were part and parcel of a new psycho-geographic regime demarcating the social and metaphysical lines that were necessary to distinguish black from white, civilization from nature, citizen from foreigner, past from present, reason from supernatural or folk forms of knowing, and — ultimately — living from dead. Modern social orders, Roach argues, are orchestrated around the rationalized, proper interment and sequestering of the dead in their "assigned" spaces.

But the dead are seldom content to stay in their graves. That these attempts to sequester the dead in places distinct from the place of the living seldom succeed will come as no surprise to readers of this volume. The gothic formations shortly to be attendant upon Enlightenment, hastily defined, are symptomatic of the failure to properly inter the dead. Here is the critic, Eric Anderson, speaking of undeadness:

Undeadness describes a wide continuum of posthumous phenomena, from funerary rites and mourning practices to the shocking overwhelming affect of terrifying spectacles and posttraumatic flashbacks, to figures from beyond death: ghosts, vampires, zombies, but also corpses unburied, decayed, desecrated, dismembered, yet still filled with life, or a kind of life, be it with the multitude of micro-organisms drawing sustenance from decomposing bodies or the 
psychical afterlife of remembering the dead. This necrological impulse can also incarnate in metaphorical ways in texts that may not feature literal revenants but that present tropes of undeadness. $(2015$, p. 1$)$

In this sense, "gothic" romanticism-Mary Shelley's Frankenstein, for example-represented the development of a sort of unnatural chiaroscuro effect, whereby such lines of distinction became blurred, wherein dead flesh becomes re-animated, where corpses rise from graves to contaminate the spaces of the living. In contradistinction to cultural formations that "view the dead as hermetically sealed off from contemporaneous life, quarantined into the past," gothic cultural productions, as Anderson et al. have argued recently in Undead Souths, reveal "how the dead contain cultural vibrancy in the present" (2015, p. 2).

Ventriloquizing the dead is the most urgent of cultural tasks. I very much believe that the gothic pervades the contemporary moment. In Haints, I argued that contemporary gothic writing has, since the millennium's turn, worked to undo national and progressive American narratives "by excavating alternative histories or ghost stories, by imaginatively summoning into presence those voices and beings that have been sacrificed to the march of progress and the consolidation of American literary and cultural traditions" (Redding, 2011, p. 39). And I have argued in an essay on what I term ethno-gothic (Redding, 2015) that there is - or "are" rather - diasporic gothics occasioned in, by and of the imaginaries of the millions of migrants and refugees that are now wandering the globe. Here, I want only to say a few things about American writing, because my initial source is Faulkner, whose work epitomizes what critics often term "Southern Gothic." I will confine myself to a discussion of two (or three) modernist writers from the American South.

Southern Gothic (sometimes Southern grotesque) is a critical term that traditionally refers to the literature produced by Faulkner and other key modernist writers of what was termed the Southern Literary Renaissance of the 1920s and after. Edgar Allan Poe is generally considered the great predecessor to this tradition; Tennessee Williams is often mentioned as well, along with such luminaries as Flannery O'Connor, Carson McCullers, James Agee, at times, or and, somewhat later, Cormac McCarthy. Faulkner's suggestive observation, in Requiem for a Nun (originally published in 1951) that, in the American South, "the past is never dead. It's not even past" (2011, Act I, scene 3) points to the historical persistence in the region of an array of unresolved crises: of its brutal and still unresolved history of enslavement, Jim Crow, and racial violence; ghosts of the genocidal displacement of indigenous Americans, as critics allied with the New Southern Studies argue; of the deep poverty that ensnared working whites within the neo-feudal system of sharecropping during the long economic reign of King Cotton over vast swaths of the region; of the exploitation of coal miners and rural farmers in the remoteness of Appalachia; of a long history of industrial underdevelopment and the neglect of educational institutions.

More broadly, for many contemporary critics, consequently, it is the long, sad history of racial and economic injustice (in the South, and elsewhere) that forms the contours of a specifically American gothic writing, and increasingly, cultural historians have articulated the centrality of American Gothic. The critic Justin Edwards, for example, who connects 
American gothic writing with Freud's theory of the uncanny and with the repressed history of racial "miscegenation" in American life, writes that "there is a sense of strangeness when the unfamiliar appears at the center of the familiar" (2003, p. xxv). And for Teresa Goddu, in Gothic America (1997), as for Kathleen Brogan in Cultural Haunting (1998), homage to the dead is central to the project of American renewal. Brogan points to unsuccessful rituals of burial and to Freud's assessment of melancholia as an unresolved act of mourning on the part of various racialized or minority or immigrant social communities across the new world, who have been violently severed from their pasts or traditions via subjugation, genocide, enslavement, or displacement. Goddu states categorically:

The American Gothic is most recognizable as a regional form. Identified with gothic doom and gloom, the American South serves as the nation's "other," becoming the repository for everything from which the nation wishes to dissociate itself. The benighted South is able to support the irrational impulses of the gothic that the nation as a whole, born of Enlightenment ideals, cannot. (1997, p. 3)

In their introduction to the very new Palgrave Handbook of Sothern Gothic, Charles Crow and Susan Castillo Street concur:

Indeed, the South is a region that has always been obsessed with crossroads and boundaries, whether territorial (the Mason-Dixon line) or those related to gender, social class, sexuality and particularly race. In the South, ghosts and men in white sheets are real, as are shackles and clanking chains, and the Southern Gothic is a genre that arises from the area's often violent and traumatic history. (2016, p. 2)

So too Patricia Yaeger (2000), who in a now classic study that surveys writing from the South by both white and African American women, finds that the racial divide also functions as a kind of mirror, through which when we look, Freud says, we see an alienating figure that turns out to be ourselves. Noting the striking similarities in narratives by southern women writers of different racial backgrounds, Alice Walker and Kate Chopin, Yaeger points to a "haunting in the world of common reality - a world of striking gender inequality, a world unevenly shared by the two races. . . both Chopin [in "Désirée's Baby" 1894] and Walker [in The Third Life of Grange Copeland (1988)] invent heroines who respond to racism by destroying themselves and 'becoming' a landscape" (Yaeger, 2000, p. 43).

In Chopin and Walker, women whose agency threatens the social are killed off. This observation leads me back to Faulkner's Addie Bundren. As a cynic and a non-believer, Addie is condemned for the "sin" of being un-Christian. She confesses to the reader another infidelity: she has had an affair with the preacher (Wainwright). Women's capacity for agency, sexual, intellectual or otherwise, taboo everywhere, is particularly so in the American South, a society wholly dedicated to the cult of femininity, to preserving the imagined virtue of white womanhood. This is why there is always a "corpse bride" at the heart of the gothic text (Addie, in Faulkner); this is why there are corpses of so many women scattered across the literature of the American South. 
"The death of a beautiful woman is, unquestionably, the most poetical topic in the world," writes Poe, notoriously, in his manifesto, "The Philosophy of Composition," from 1846. The great poet of necrophilia, Edgar Allan Poe, is no doubt key to understanding the Southern Gothic. As Tom F. Wright has argued, Poe's works offer a powerful gothic critique of "nineteenth-century society, its values, contradictions and myths - in their spare glimpses of life below the Mason-Dixon line, but perhaps even more visibly in the seemingly placeless depictions of nightmarish aristocratic landscapes" (2016, p. 10). Wright, somewhat surprisingly, scants Poe's sexual perversions. Perhaps Ishmael Reed's commentary about Poe's sensibility is more to the point. Reed conflates Poe's penchant for necrophilia, his fear of premature entombment, and his insistence that there is nothing more sublime than the corpse of beautiful girl with the Civil War and with racial pathologies of American history:

Why isn't Edgar Allan Poe recognized as the principle biographer of that strange war? Fiction, you say? Where does fact begin and fiction leave off? Why does the perfectly rational, in its own time, often sound like mumbo-jumbo? Where did it leave off for Poe, prophet of a civilization buried alive, where according to witnesses, people were often whipped for no reason? Will we ever know, since there are so few traces left of the civilization the planter's called "the fairest civilization the sun ever shown upon," and the slaves called "Satan's kingdom." Poe got it all down. Poe says more in a few stories than all of the volumes by historians. (1976, pp. 18-19)

The quotation is from Reed's satirical novel, Flight to Canada, which was published during the United States' bicentennial year, 1976, and which refigures both Harriet Beecher Stowe's Uncle Tom's Cabin (1852) and the tradition of American slave narratives. Reed's hoodoo revision and interrogation of the American mythmaking apparatus gauges the reciprocal interpenetration of fact and fiction, assessing the productive capacities of literature, its often magical world-making powers, to use the terms of Djelal Kadir. In his discussions of World Literature, Kadir points out that we can take the term "world" as a verb: literature worlds, and, consequently, the critic's task is to "world" literature, "to give it," as Kadir writes, "a particular historical density" (2004, p. 2). Kadir, who elsewhere commends Poe for providing in his writing "an ironically inadvertent replication of America's political unconscious" (2010, p. 18), would agree with Reed that "Poe says more in a few stories than all of the volumes by historians" (1976, p. 19). Poe is in that sense a southern writer; the American South produces Edgar Allan Poe. Poe excavates the political unconscious of the American South - they are mutually constitutive.

There is a deep connection, then, in the deep imaginary of the American South, between places - the land - and corpses, particularly the corpses of brides. Yaeger notes the recurrent image of women's grotesque or monstrous or monstrously large bodies in southern women's writing, theorizing perceptively that, via the cult of womanhood, the white woman's body - and the necessity to protect it from assault — forms the core of the mythic "self-definition" of the American South; thus the "corpse/woman" is subject to all manner of regulation and (quite literally) restraint; in this sense the control of women becomes the very mechanism for control over modern regimes of segregation. Yaeger writes: 
the racially pure and diminutive female body in need of protection becomes the motive force, the purported source for the taboo against race-mixing. As southern myth, this fragile white body helps motivate (1) southern modes of population control, reproducing black and white populations as separate, (2) the regulated segregation of these bodies in space, and (3) the need for deeply interiorized categories of racism that will do the work of segregation. In other words, the small compass of the ideal white woman's body is oddly at war with its epic stature in the minds of white men. This fragile white body, slim as a reed and graceful as a sylph, becomes pivotal in each crucial task of bodily discipline. (2000, p. 120).

To conclude, I want to look briefly at another text, about a similar journey-the journey of the corpse in its coffin, which is being taken by the surviving spouse from the place of death to its burial at home. The book is titled, with some resonance, Dead Lovers are Faithful Lovers, written by another southern writer, the feminist modernist Frances Newman, and published in 1928, two years before As I Lay Dying. Newman is largely forgotten today, even by revisionist critics with feminist sensibilities - some attention paid by feminist historians in the 1980s and 1990s, when my edition was printed. Barbara Ann Wade published a biography in 1998, but there has been almost nothing since then. Newman does not even merit a mention in Yaeger's great survey of southern women's writing, Dirt and Desire. To be fair, Yaeger's study covers works from 1930 - two years after Newman's deathto 1990 , but even so, it seems an oversight. But Faulkner doubtless would have known the text - this, along with Newman's first novel, The Hard-Boiled Virgin (originally published in 1926), both sharply barbed satirical attacks on the sexual customs and rigid social hierarchies of the American South, caused quite a scandal upon their publication. The novel, however, is hardly gothic. Newman's style is arch, elegant, modernist; the stream of consciousness technique is more reminiscent of Virginia Woolf or (in its pointed repetitions and sexually comic irony) even Gertrude Stein than it is of Faulkner, though Newman is capable, in this book, of shifting points of view in as jarringly smooth a fashion as Faulkner became famous for. The critic and doyen of the southern agrarians, Donald Davidson, lamented that her writing too closely resembled "defeated Europeans like Joyce and jabbering expatriates like Gertrude Stein” (as cited in Jones 1994, pp. viii-ix).

Like As I Lay Dying, Dead Lovers tells the story of a love triangle: the well-born Evelyn Cunningham remains passionately in love with her husband, Charlton, but risks losing him to the seductive temptations of a rival, Isabel Ramsay. Evelyn is a highborn aristocrat, of an old and highly respectable southern family; she marries Charlton, executive for the Southeast railroad, thus wedding the prestige of her family to the newly industrializing and capitalist South. Isabel Ramsey is, by contrast, a new woman, a jazz age flapper, employed as a librarian, and an intellectual: she reads Eliot's "The Waste Land" in 1922, the year it is published, and is constantly trying to impress on her library patrons the importance of such new writings as those of Joyce or Fitzgerald. Though we never enter inside Charlton's head, he wavers between the wife and the mistress, each of whom lays competing symbolic claims over the twentieth-century American (his name is evocative of the city of Charleston, in South Carolina). Among Newman's many sly ironies in this novel, however, is that neither of the women is content to be rendered as "symbol," much less as a gothic victim 
or villain. As Anne Goodwyn Jones notes in the foreword to the 1994 edition of the novel, "the minds of [Newman's] urban are intricate, complicated, informed, careful, in a word urbane - much like their social South, and Newman's style" (1994, p. xxvii). Among its other subversions, this book takes readers inside the minds of both the modern new woman and the grand belle of the old South, both of whom are articulate, unbowed, assertive, sexual, and self-conscious about their passions. Neither will submit, neither will surrender. Evelyn, for example, suffers the disconnect between her sexual and emotional passion and the very social ideals to which her rank and position and gender yoke her:

Evelyn Cunningham lay down on her yellow chaise longue [sic] and shut her eyes. She pressed a hot cheek against the cold right hand which was holding her warm right shoulder, and she let her cold left hand press its fingers around her warm right breast.

She still felt that her whole life was beating against her arms. And she felt that a little echo was beating against the back of the left hand which was touching her throat, and that a terrifying conviction was flying down to strike against her tired mind - a conviction that she already loved her husband more than he loved her.

Another conviction flew down and struck against the mind that already felt full and tight like an aching tooth. And she began to be afraid that Charlton Cunningham might have begun to love her in the gold and scarlet glamour of the homage which had painted the footlights of the beautifully set stage where he had first seen her, and that she could not make scarlet and gold footlights for herself on this narrow new stage, and that she might live long enough to die on the day when he did not love her at all. (1994, pp. 45-46)

So, what will happen? Two passionate lovers, one man. Against expectations, against gothic conventions, the plot is resolved when Charlton sickens and dies. At the center of this novel is the corpse of a beautiful young man. Again, taking his cue, Faulkner will famously invert the same set of expectations in his acerbic portrait of the necrophiliac Emily Grierson, in his much anthologized "A Rose for Emily," first published in The Forum in 1930.

The corpse groom does not speak. It is his body that is being conveyed from his deathbed in New York to his burial ground in Atlanta, via a private railroad carriage: as Aristocrats, the Cunninghams (dead and alive) travel in more elegant style than do the Bundrens. We witness, in the final episode of the novel, Evelyn Cunnigham carefully dressing herself in widow's black; her widowhood secures her victory over her rival, even as it secures and cements her social status, as Poe's raven would say, forevermore. However comic or ironic her vision, Newman knows the old South will never succumb to the seductions of the modern. We see Evelyn descend, regally, in mourning, as the train arrives in Atlanta, "as she lifted her hand to her little hat, it did not tell her that she felt herself walking at last on the green oasis of a memory over which she was dropping the victorious curtain of her very long black crape veil" (1994, pp. 294-295).

And where does that leave the dead to rest? Ultimately, they go to rest with us. 


\section{References}

Anderson, E. G., Hagood, T., \& Turner, D. C. (2015). Undead Souths: The Gothic and beyond in southern literature and culture. New Orleans: Louisiana State University Press.

Bradbury, J. M. (1963). Renaissance in the South: A critical history of the literature, 1920-1960. Chapel Hill: University of North Carolina Press.

Brogan, K. (1998). Cultural haunting: Ghosts and ethnicity in recent American literature. Charlottesville: University of Virginia Press.

Crow, C. L., \& S. Castillo Street (Eds.), 2016. The Palgrave handbook of the Southern Gothic. London, UK: Palgrave Macmillan.

Dufresne, J., \& Wade, J. M. (2013, August 22). The Rumpus interview with John Dufresne. The Rumpus. Retrieved August 20, 2016 from: http://therumpus.net/2013/08/the-rumpus-interview-withjohn-dufresne/

Edwards, J. D. (2003). Gothic passages: Racial ambiguity and the American Gothic. Iowa City: University of Iowa Press.

Faulkner, W. (1990). As I lay dying. New York, NY: Vintage.

Faulkner, W. (2011). Requiem for a nun. New York, NY: Knopf.

Goddu, T. (1997). Gothic America: Narrative, history, and nation. New York, NY: Columbia University Press.

Jones, A. G. (1994). Introduction. In F. Newman (Ed.), Dead lovers are faithful lovers (pp. iv-xxxvi). Athens: University of Georgia Press.

Kadir, D. (2004). To world, to globalize: Comparative literature's crossroads. Comparative Literature Studies, 41.1, 1-9.

Kadir, D. (2010). Edgar Allan Poe: America's conscience and epistemic anxiety. In L. Juárez (Ed.), Poe alive in the century of anxiety (pp. 17-30). Madrid, Spain: Instituto Benjamin Franklin.

Newman, F. (1926). The hard-boiled virgin. New York, NY: Boni \& Liveright.

Newman, F. (1994). Dead lovers are faithful lovers. Athens: University of Georgia Press.

Poe, E. A. (1946). The philosophy of composition. Retrieved February 28, 2017 from: http://www.bartleby.com/109/11.html

Redding, A. (2011). "Haints": American ghosts, millennial passions, and contemporary Gothic fiction. Tuscaloosa: University of Alabama Press.

Redding, A. (2015). Ethno-Gothic: Repurposing genre in contemporary American literature. In J. Haslam \& J. Faflak (Eds.), American Gothic culture: An Edinburgh companion (pp. 60-76). Edinburgh, UK: Edinburgh University Press.

Roach, J. (1996). Cities of the dead: Circum-Atlantic performance. New York, NY: Columbia University Press.

Reed, I. (1976). Flight to Canada. New York, NY: Random House. 
Wade, B. A. (1998). Frances Newman: Southern satirist and literary rebel. Tuscaloosa: University of Alabama Press.

Wright, T. F. (2016). Edgar Allan Poe and the Southern Gothic. In C. Crow \& S. Castillo Street (Eds.), The Palgrave handbook to Southern Gothic (pp. 9-20). London, UK: Palgrave Macmillan.

Yaeger, P. (2000). Dirt and desire: Reconstructing Southern women's writing, 1930-1990. Chicago, IL: University of Chicago Press. 


\title{
On the Threshold: Haunting Transgressions in Gaétan Soucy's The Little Girl Who Was Too Fond of Matches
}

\author{
Zuzanna Szatanik \\ University of Silesia in Katowice \\ zuzanna.szatanik@us.edu.pl
}

Received 6 March 2017; accepted 18 October 2017.

\begin{abstract}
The main aim of this article is to show how Gaétan Soucy's 1998 bestselling novel The Little Girl Who Was Too Fond of Matches both extends and complicates the Canadian Gothic tradition. The first part focuses on Canada as a "haunted culture," and attempts to identify the ghosts which haunt Canada and make themselves manifest in the nation's gothic literature. I ponder the postcolonial character of Canadian Gothic, and reflect on the representations of monstrous nature in Canada's early fiction. A short section is devoted to the characteristics of French-Canadian Gothic. The second part of my article proposes a reading of Soucy's novel which concentrates on gothic transgressions the story revolves around. One of my assumptions is that the novel invites ecocritical and ecofeminist interpretations, and that its representations of nature also reveal the subversive character of the text whose narrator, by her own admission, locates herself on the threshold of things.
\end{abstract}

Keywords: Canadian literature; Quebec literature; Canadian Gothic; Gaétan Soucy; transgression.

The main goal of my article is to show how Gaétan Soucy's 1998 The Little Girl Who Was Too Fond of Matches both extends and complicates the Canadian Gothic tradition. Originally published in French, Soucy's novel has since been translated into more than twenty languages, and has become one of the most recognizable French-Canadian literary works. Its author, in a way reminiscent of Edgar Allan Poe, has been described as "a strange and difficult man" who "battled demons." His untimely death in 2013, more than a decade after he published his last novel Vaudeville!, only added more gloom to his already dismal 
image. The Little Girl, similarly, has attained a near-mythical ambience, as it took Soucy less than a month to write. Allegedly, the story was created during an epic ice-storm which paralysed Quebec in January 1998, imprisoning thousands of people in their homes (Hustak, 2013). A mystifying read, the short novel is a little book of excess, a "grimoire" (Whelan, 2011, p. 178), whose labyrinthine structure is built on countless gothic tropes. Narrated by a character whose name is only revealed on the last pages of the story, and whose gender remains mysterious for a good part of it, The Little Girl revolves around the themes of crime, mystery, victimization, death, transgression and punishment. Whereas a reading of Soucy's novel remains the primary goal of this article, its introductory part is built on the assumption that Canada, like other nations, has been haunted, and aims to identify the specific order of ghosts haunting Canadian literature.

There are a number of quotations that have turned to be milestones in English-Canadian nation/narration which invoke ghosts, or rather the absence thereof. For example, in 1836 The Backwoods of Canada, Catharine Parr Traill "famously proclaimed that Canada was "too matter-of-fact a country for the supernatural"' (Sugars, 2009, p. xiii). In 1852, her sister Susanna Moodie insisted that the country "was too new for ghosts" (in Sugars, 2009, p. xiii). Over a century later, Canadian poet Earle Birney wrote in his poem entitled "CanLit" that "it's only by [their] lack of ghosts [that Canadians are] haunted" (in Sugars, 2009, p. xiii). Finally, a protagonist of Margaret Atwood's early novel Surfacing, "makes a comment that has become one of the most widely circulated citations in Canadian literature. 'Canada was built on dead beavers,' he says" (Berland, 2015, p. 25). Whereas the last quotation does not mention ghosts per se, it complements the other statements in that it seemingly de-gothicizes Canadianness. What it suggests is that there is pragmatism to Canadianness, and some irony too, which are not consonant with the gothic mode. Canadians, in Cynthia Sugars' words, "[inherit] a niggling sense that they [are] dull" (2009, p. 3).

Contrary to what these sober citations suggest, all of the four writers mentioned above repeatedly referred to Canadian nature as mystifying and threatening. To the $19^{\text {th }}$-century settler women, wilderness loomed both breathtaking and hostile. In Margaret Atwood's poetic retelling of Susanna Moodie's journals, as well as in Birney's poem entitled "Bushed," nature confounds, petrifies, and drives one insane. This is why, as Northrop Frye famously proclaimed, Canadians develop a garrison mentality to protect themselves from the adversities of nature (1973, p. 830). In fact, in her seminal 1972 study entitled Survival: A Thematic Guide to Canadian Literature Atwood affirms that "Nature the Monster" is one of the most prevalent themes in Canadian letters, as "there's lots of water and snow in Canada, and both are good murder weapons" (1972, p. 55). Deadly wilderness becomes, therefore, one of the most haunting presences in Canadian fiction. This form of haunting, in the words of Jennifer Andrews, "takes two forms: the literal fear of the untamed natural world encountered by new immigrants and the accompanying realization that such perceptions of emptiness depend upon often naive presumptions of what constitutes civility and order" (2009, p. 210). Forts, in truth, offer only illusory protection against the wilderness and often become sites of haunting transgressions. 
Whereas Atwood's early interest was in delineating Canadian national myths - the interest she shared with other thematic critics - present-day Canadian writers are invested in "deconstructing [these very] national myths that, created in the 1960s, have . . haunted literary and cultural production in Canada since" (Darias-Beautell, 2012, p. 4). In Marlene Goldman and Joanne Saul's terms, they are, in fact, "obsessed with ghosts and haunting" (as cited in Darias-Beautell, 2012, p. 7), and have been led, as another critic professes, "to conjure, and indeed channel, the crowded landscape of ghosts and monsters that circulate above, around, and within the parameters of the Canadian nationalist project" (Sugars, 2009, p. xiii). Arguably, Canadian literature still somehow "feeds upon" old myths, by way of "negotiating with the dead" and "bringing to the fore a sense of the forgotten and unacknowledged, the repressed and the denied" (Sugars, 2009, p. xiv). These gothic gestures are aimed against the apparent "'stupefying innocence' in Canadian nation-narration" (Kulperger, 2009, p. 101) as "[t]he Canadian discourse of the nation is haunted by the spectre of Aboriginal and diasporic others - a haunting that renders problematic the construction of a cohesive national identity" (Laouyene, 2009, p. 127).

The belief in the supposed innocence of Canada's past is reflected in the famous quotation about dead beavers I brought up earlier; "The beaver," continues Atwood's protagonist, "is to this country what the black man is to the United States" (Berland, 2015, p. 25). The present-day "preoccupation with haunting in Canadian writing" (Goldman, 2012, p. 5), conversely, helps to deconstruct the myth of Canada's colonial inculpability as it "seeks to, above all, materialize and familiarize [the] motifs of trauma . . grounding [it] in the brutal realities and ongoing legacies of colonization" (Kulperger, 2009, p. 98). In Marlene Goldman's words,

In a country like Canada, with four major waves of immigration after the initial period of British and French colonization, and a fifth wave that is currently ongoing - the tropes of (dis)possession and haunting may be a particularly useful way to think about the relationship between history and memory, about displacement, about ancestors, and about inheritance. (2012, p. 15)

It is then not the beaver that is the black man of Canada; it is the black man that is the black man of Canada where "slavery was practiced in a third of what" now constitutes the country (Goldman, 2012, p. 9). The Canadian writers who use "traditional gothic conventions" often do so in order "to expose the lingering remnants of the past within the presentday postcolonial nation” (Kulperger, 2009, p. 98).

Whereas the colonial legacy haunts the literatures of both English and French Canada, there are a number of symbols and metaphors which have been linked specifically to Quebec Gothicism. According to Atwood, the characters of English-Canadian literature are sentenced to "death by nature," while French-Canadian protagonists burn to death in their mansions (1972, chapter 11). English-Canadian gothic literature often expresses "guilt concerning [the] treatment of the indigenous peoples" and "the legacy of slavery" (Goldman, 2012, p. 9), whilst French-Canadian Gothic, as Michel Lord suggests, 
seems content to deny history or even to ignore that it happened. Historical reality, be it the fact that the Acadians were deported or the fact that New France did fall, is rejected in favor of a fictional "dream-state" whereby a lost past is imaginatively restored. (as cited in Cabajsky, 2009, p. 6)

This, in Lord's words, “is responsible for French-Canadian Gothic's conservative tenor" (as cited in Cabajsky, 2009, p. 6). Among the typical themes in French-Canadian gothic fiction, Cedric May mentions the theme of ancestral home, "harking back to the seigneurial origins of Quebec society," and "the tragic orphan theme" (May, 2002). Even though pointing out which of these motifs are present in Soucy's novel would be a rather uncomplicated task - as many of them were employed by the author of The Little Girl - the following interpretive part of my presentation focuses on gothic transgression, a classic gothic trademark, which makes Soucy's work a subversive rather than representative example of the French-Canadian tradition. As a gothic story, The Little Girl "both enacts and thematizes ambivalence" (Sugars, 2009, p. xv) and refuses to fully align itself "with [any] nationalist theology" (Cabajsky, 2009, p. 6). Accordingly, the frame-or a skeletonupon which the story is built is conspicuously inscribed within the classic gothic mode.

The Little Girl Who Was Too Fond of Matches, which is divided into two parts and "spans a time frame of [merely] two days" (Wiesenthal, 2014), tells the story of the Soissons family "whose [seemingly] arcadian existence [was] shattered" (Cabajsky, 2009, p. 3). The opening paragraphs of the novel are perplexing, as the events unfold abruptly and the language in which they are told is mystifying itself. The story begins with a suicidal death of the autocratic father of the family - the "papa" who "gave up the ghost without a by-yourleave" (Soucy, 2000, p. 3) - and the decisions his two children have to make on discovering his body. The setting is an old ruined mansion, a symbol of the family's past wealth and its present disintegration. In this Pandora box of a beginning, uncomfortable secrets of the family are hinted at, the first of which being that the father had kept his children imprisoned in the house, preventing them from virtually any contact with the outside world. The reader also learns about a mysterious creature named the Fair Punishment, kept in a box in a woodshed, aka "the vault" (p. 8), to which the narrator refers to as "quite something" which "will surprise the world one day" (p. 8). The vault is also a place where a puzzling glass box is stored, which the narrator promises to talk about later, "in the proper place at the proper time" (p. 8). Before ascertaining the "papa's" death, she suspects the man was simply having "a stopit" without explaining what it might indicate.

Some of these puzzles are only explained on the last pages of the novel - it is how the narrator's name, Alice, is revealed-some are never clarified. The stopit, for instance, which runs in the family, has been most often interpreted as an epileptic fit, but could as well indicate a panic attack. What we do learn, on the other hand, is that the Fair Punishment is the eponymous little girl who was too fond of matches, and the narrator's twin sister Ariane. At the age of three Ariane set the mansion on fire in which her mother died, and in which she was severely burned. In an act of "fair punishment," the father put his harmed child in a box to which she is now chained, and locked her in the "vault" together with the body of the mother-kept in the glass coffin — and a box of matches, a constant 
remainder of Ariane's sin for her to contemplate. In the background of these ghastly revelations, we also learn that the narrator has "hidden away to flee the disaster and to write [her] last will and testament" (Soucy, 2000, pp. 8-9) which is the text itself. The chronicler weaves her story hastily and in secret, which is why it seems disordered, and often proffers overlapping realities and temporalities.

The distinctly gothic character of Soucy's novel is evoked not only through the classic gothic tropes or crime, mystery, and danger but through the deliberately de-naturalized, transgressive language of the text. What the two children know about the world comes from their limited experience and, more importantly, from the biblical and philosophical texts, as well as tales of chivalry that their father - a former priest become a mine owner-fed them with. The language the narrator uses is therefore strangely archaic, and is "an oddly extravagant pastiche of stylized 'days of yore' (3), private euphemism, poetic neologism, inadvertent malapropism, comically blunt literalism, and snatches of contemporary slang" (Wiesenthal, 2014). It is also the language that represents the "perverse symbolic order" of the dead father (Wiesenthal, 2014), in which women are either "sluts" or "blessed virgins," breasts are referred to as "inflations," and male genitals become "attributions." In a disquietingly detached manner, the narrator uses this language to describe her father's corpse:

since father was dressed like eve, it was as if we were on first-name terms with his balls. They were all soft and chubby, much bigger than brother's, or mine in the days when I still had them, and they hung there on the stiff white body like a bearded baby's face. (Soucy, 2000, p. 18)

In a similarly dispassionate, estranged way she asserts having been repeatedly raped by her brother, and mentions her practice of "flicking [menstrual] blood" at him as a defensive gesture.

As the story develops, however, the narrator seems to appropriate her father's language and the text transforms from a daily exercise in noting down important events (which the family practiced) into an emotional private confession and a trauma narrative. The narrator's own story breaks through the complicated linguistic net fabricated by her father. Soucy's then is "a nightmarish subversion of the fairy-tale mode" (Wiesenthal, 2014), which details numerous rites of passage that culminate in the metamorphosis of the narrator, the rites whose outcomes, however, are never definitive. In the subsequent parts of this essay, for the sake of clarity and in respect of space limits, I focus on merely three different examples of gothic transgressions presented in The Little Girl. These concern the crossing of the borderlines between the inside and the outside, the subverting of the categories of gender, as well as the undermining of the distinction between human and animal.

The most literal transgression the narrator experiences is the overstepping of the boundaries of her father's domain marked by a pine grove "blocking the horizon" (Soucy, 2000, p. 7), and entering the village on the other side of it. The act of crossing over the boundaries of the estate is not only one of necessity - she feels obliged to buy a "grave box" to bury her father in - but also disobedience. As a violation of their father's strict rules, it frightens her brother much more than the prospect of staying in with the corpse. The liminal space 
of the road leading to the village is an uncharted territory which the narrator tests "with the toe of [her] boot before setting out along it for the first time in [her] life" (p. 27). She is surprised the earth does not yield and is "able to support [her] there too" (p. 27). The girl enters the unfamiliar realm armed with a spade "to defend [herself] against serpents or lions" (p. 29) and expects there to be "a palace with a drawbridge and flying carpets overhead" (p. 29). Instead, the landscape she intrudes is recognizably Catholic, with its center marked by a church in which a funeral service is being held.

Although the narrator "[knows] a thing or two about [churches as] ever since [she]' $d$ been old enough to remember being hit, father had taught [her] all the things in a church inside and out" (Soucy, 2000, p. 30), this public space proves to be as hostile as her father's. Misunderstood by the inhabitants of the village and threatened by the crowd in the square outside the church, the girl finds herself "in the grip of a stopit" (p. 43). "When I have a stopit," she explains, "time contracts or expands or goes in circles, it's impossible to know" (p. 43). In this surreal state, her body shuts down, but the girl remains "extremely active on the inside" (p. 43); "I look through my ruminant eyes," she intimates,

as I would look through a window with the eyes we have inside our bonnets, I observe everything in every direction so that nothing escapes me, I climb inside my body as if I were hiding in the attic and spying on the world through the bull's eye, ah la la, another eye. (p. 43)

A stopit thus is an extreme experience of derealization which transcends logic, in which the girl seems both dead and alive, animate and inanimate, in control and out of it. Even though the stopit is temporary, and the narrator's quest is unsuccessful (its consequences, in fact, prove to be disastrous for the Soissons siblings), what the girl learns through "stepping outside the enclosure of the estate" is that "once that boundary had been crossed [she] could pass through the others as easily..." (Soucy, 2000, p. 32). Freed from her father's regime and unfitted for the narrow structures of the village, the narrator positions herself on the threshold (p. 112), and wishes "to stay forever on the road through the pine grove" (p. 64), in-between the realm of the father and the realm of the priest. It is outside of her ancestral home, as well as outside of the village, in the transgressive "outside of" space, that the girl wishes to dwell.

The narrator's spatial dislocation harmonizes with her crossing over the boundaries of gender. Raised as one of her father's "thin, daydreamy sons" (Soucy, 2000, p. 13), in the first part of the novel she seems to accept the kind of identification that her father forced upon her. As she reveals,

Once upon a long time ago, a true calamity happened to me, I think I lost my balls. I bled for days and then it healed over and then it started up again, it depends on the moon, ah la la, it's because of the moon, and I started to get inflations on my torso as well. (p. 56)

As a castrated boy with "inflations," the narrator is conflicted as to her own gender identity, also for the reason that according to her father's teachings most women are sluts, and the blood she drips is "disgusting" (Soucy, 2000, p. 44). It is only at the end of the first part of the novel, after she narrates having had sex with a mine inspector-whom she 
refers to as a knight, a prince, and a handsome cavalier - that the narrator decides to "use the gender of sluts for [her] pronouns" although she still defines herself as "[her] father's son and [her] brother's brother" (p. 61).

Finally, in the second part of the book, a realization "[springs] to [the narrator's] mind like a tiger" that she "too [is] a soissons slut" (Soucy, 2000, p. 77). This is followed by a recognition that having been treated like a son by her father "put a rod between [her] legs, figuratively speaking" (p. 128), and a startling revelation that the process of writing her testimony-which she has been engaged in for two days - is mirrored by the process of giving birth to her child whom the narrator suspects to be a girl, and plans to name Ariane, in memory of Fair Punishment (p. 137). The narrator's body, therefore, becomes a site of a corporeal transgression.

Coming to terms with her markedly female body is depicted as a liberating experience through which Alice can now "move around freely within [herself]" (Soucy, 2000, p. 128). Undoubtedly, it also relegates her to the realm of nature which has stereotypically been associated with a woman. Regardless of its emancipatory qualities, however, the girl finds nature both mighty and confounding (p. 132). Accordingly, although the girl's testimony revolves around the seemingly clear contrast between culture and nature, the boundaries between the two are always transgressed. One of the most striking characteristics of the novel, for example, are the constant references to the animal world and - in line with the principal tenets of human-animal studies - the blurring of the distinction between human and animal. The girl's faithful companion is not her brother but a horse who "lacks only the power of speech, and even that depends on what you call speech" (p. 74). The Fair Punishment, chained to her box and speechless, is unmistakably animal-like. The narrator's half-witted brother looks "like an animal that's being beaten and doesn't understand why" (p. 5). The crowd outside the church transforms "into a long undulating animal, a kind of snake with feet and, for the snout, a coffin" (p. 37), and partridges panic because “it's only human" (p. 27).

In the second part of the novel Alice's narrative develops towards an environmental poetics and ecological imagination. "The beasts," she proposes, "are as immaculate as the palm of the clouds, which are innocent to the core" (Soucy, 2000, p. 135); "Beets are like us, and so are the rats that gnaw them" (p. 97). The narrator sleeps outside and eats only plants. At the sight of her father and brother eating partridges she experiences extreme revulsion: "I'd have vomited my insides out if anyone had obliged me to put pieces of boiled partridge corpse in my mouth, and I was crying inside as I watched them eat, though it didn't show" (p. 107). The family mansion is now overtaken by nature, with "rot and corruption lying ... everywhere" (p. 89), and the corpses of farm animals starved by her father decomposing all around the estate.

Arguably, Alice uses animal metaphors to express her intense vulnerability and to lay emphasis on the transitory, slippery nature of any role and position available to her. Accordingly, this open-ended narrative closes at "a moment of pure potentiality" when nothing is certain, the moment of "imminent birth and/or death" (Wiesenthal, 2014). Even though 
the novel abounds in other classic gothic motifs (such as mystery, crime, or ghostly murmurs in an abandoned ballroom), as well as recognizably French-Canadian gothic tropes (be it an ancestral home, a burning mansion or a tragic orphan), it is, I believe, gothic transgression which becomes the most haunting — and also the most Canadian — presence in Soucy's novel.

\section{References}

Andrews, J. (2009). Rethinking the Canadian Gothic: Reading Eden Robinson's Monkey Beach. In C. Sugars \& G. Turcotte (Eds.), Unsettled remains: Canadian literature and postcolonial Gothic (pp. 205-227). Waterloo, ON: Wilfrid Laurier University Press.

Atwood, M. (1972). Survival: A thematic guide to Canadian literature. Toronto, ON: Anansi.

Berland, J. (2015). The work of the beaver. In T. Allen \& J. Blair (Eds.), Material cultures in Canada (pp. 25-50). Waterloo, ON: Wilfrid Laurier University Press.

Cabajsky, A. (2009). Catholic Gothic: Atavism, orientalism, and generic change in Charles De Guise's Le Cap au diable. In C. Sugars \& G. Turcotte (Eds.), Unsettled remains: Canadian literature and postcolonial Gothic (pp. 1-21). Waterloo, ON: Wilfrid Laurier University Press.

Darias-Beautell, E. (2012). Introduction: Why Penelopes? How unruly? Which ghosts? Narratives of English Canada. In E. Darias-Beautell (Ed.), Unruly Penelopes and the ghosts: Narratives of English Canada (pp. 1-18). Waterloo, ON: Wilfrid Laurier University Press.

Frye, N. (1973). Conclusion. In C. F. Klinck (Ed.), Literary history of Canada: Canadian literature in English (pp. 821-849). Toronto, ON: University of Toronto Press.

Goldman, M. (2012). DisPossession: Haunting in Canadian fiction. Montreal, QC: McGill-Queen's University Press.

Hustak, A. (2013, July 18). Quebec writer Gaétan Soucy was preoccupied with alienation. The Globe and Mail. Retrieved September 9, 2016 from http://www.theglobeandmail.com/arts/books-andmedia/quebec-writer-gaetan-soucy-was-preoccupied-with-alienation/article13315610/

Kulperger, S. (2009). Familiar ghosts: Feminist postcolonial Gothic in Canada.” In C. Sugars \& G. Turcotte (Eds.), Unsettled remains: Canadian literature and postcolonial Gothic (pp. 97-124). Waterloo, ON: Wilfrid Laurier University Press.

Laouyene, A. (2009). Canadian Gothic and the work of ghosting in Ann-Marie MacDonald's Fall on Your Knees. In C. Sugars \& G. Turcotte (Eds.), Unsettled remains: Canadian literature and postcolonial Gothic (pp. 125-154). Waterloo, ON: Wilfrid Laurier University Press.

May, C. (2002). Childhood lost. Canadian Literature, 175(Winter), 148-150. Retrieved September 10, 2016 from https://canlit.ca/full-issue/?issue $=175$

Soucy, G. (2000). The little girl who was too fond of matches. Toronto, ON: Anansi. 
Sugars, C., \& Turcotte, G. (2009). Introduction: Canadian literature and the postcolonial Gothic. In C. Sugars \& G. Turcotte (Eds.), Unsettled remains: Canadian literature and postcolonial Gothic (pp. vii-xxvi). Waterloo, ON: Wilfrid Laurier University Press.

Whelan, J. (2011). Interpreting comparisons in La Petite Fille qui aimait trop les allumettes by Gaétan Soucy. In P.-A. Mevel \& H. Tattam (Eds.), Modern French identities: Language and its contexts (pp. 177-202). Frankfurt am Main, Germany: Peter Lang.

Wiesenthal, C. (2014). History's absent hand: Lessons in modes of (textual) production from Gaétan Soucy's The Little Girl Who Was Too Fond of Matches. Studies in Canadian Literature, 39(2). Retrieved September 10, 2016 from http://journals.lib.unb.ca/index.php/scl/article/view/23045/26739 



\title{
Crypts, Phantoms, and Cultural Trauma: A Hauntological Approach to Recent British First World War Fiction
}

\author{
Anna Branach-Kallas \\ Nicolaus Copernicus University in Toruń \\ kallas@umk.pl \\ Received 12 February 2017; accepted 2 October 2017.
}

\begin{abstract}
In my article, I analyse selected British novels about the First World War published at the turn of the $20^{\text {th }}$ century, from the theoretical perspectives proposed by Maria Torok and Nicolas Abraham in The Shell and the Kernel: Renewals of Psychoanalysis. Pat Barker in Toby's Room (2012) and Sue Gee in Earth and Heaven (2000) imagine their protagonists' difficult evolution from melancholia to mourning after the loss of brothers and/or lovers, at the front. The concepts of incorporation and illness of mourning are used to explore the complicated process of bereavement in Barker's novel, where hauntology becomes a form of honte-ology, from the French honte, shame. In Gee's beautifully melancholic novel, the haunting trauma of loss is subtly evoked by images of empty fields, neglected farms, urban vistas filled with spectral figures of unemployed veterans. Moreover, Earth and Heaven affects the reader so deeply because the understated pain of loss becomes movingly tangible after the accidental death of the central protagonist's six-year-old son, which seems to "condense" the pain of war bereavements a decade after the conflict. My intention is also to demonstrate that Sebastian Faulks in Birdsong (1993), Esther Freud in Summer at Gaglow (1997) and Pat Barker in Another World (1998) approach the Great War as a phantom haunting their contemporary protagonists. The persistence of the unknown past has a profound impact on these characters and only by trying to relate to the Great War do they find answers to their existential dilemmas. This directs our attention to the incomplete processes of First World War mourning, the persistence of endless grief and the potential continuity of unresolved trauma(s) in transgenerational memory. The five novels under consideration also problematise the issue of silence - the unsayable family secret and/or the collective disregard for the national past. The psychoanalytic concept of crypt illuminates the relation between present and past in these fictions and makes it possible to draw
\end{abstract}


a connection with the sociological concept of cultural trauma, referring to certain foundational events constructed as traumatic from the point of view of the British collectivity.

Keywords: hauntology; British First World War fiction; cultural trauma; mourning; commemoration; family memory.

The aim of this article is an analysis of selected British novels of the Great War published during the last quarter of the century-Toby's Room (2012) and Another World (1998) by Pat Barker, Earth and Heaven (2000) by Sue Gee, Summer at Gaglow (1997) by Esther Freud and Birdsong (1993) by Sebastian Faulks - using the hauntologial paradigm proposed by Nicolas Abraham and Maria Torok in The Shell and the Kernel: Renewals of Psychoanalysis (1987; English translation 1994). The four writers approach the Great War as a spectre haunting their protagonists and/or their family lines. Commenting on the memory boom of the late twentieth century, Jay Winter highlights the growing importance of traumatic family memories in our understanding of the past $(2001$, p. 65$) .{ }^{1}$ Winter and other scholars draw the reader's attention to an important recent body of First World War fiction, in which family memories play a central function (see e.g. Renard, 2013, p. 14; Todman, 2008). This "revival" of the theme of the Great War seems today a transnational phenomenon, which signals the desire to move beyond the history of armies and battles, a framework referred to by James Campbell (1999) as combat gnosticism, which for many years has dominated First World War literature and its criticism. Approaching with caution the equation of memory with Shoah (Winter, 2001, pp. 52-53), historians and novelists exploring the 1914-1918 conflict point to its significance as the first holocaust of the twentieth-century and the obliteration of First World War traumas by Second World War memories. This in turn might direct our attention to the incomplete processes of First World War mourning, the persistence of endless grief (Audoin-Rouzeau \& Becker, 2000, p. 17) and the potential continuity of unresolved trauma(s) in transgenerational memory. In the British context in particular, the First World War might be therefore approached as a cultural trauma, a "horrendous event that leaves indelible marks upon" a collectivity's consciousness (Alexander, 2004, p. 1) and re-shapes collective identity as well as collective memory (Eyerman, 2004, p. 60). ${ }^{2}$

\footnotetext{
1 "The memory boom of the late twentieth century is a reflection of a complex matrix of suffering, political activity, claims for entitlement, scientific research, philosophical reflection, and art" (Winter, 2001, p. 65).

2 In contrast to physical or psychological trauma, which shatter an individual's life, cultural trauma refers to a collective wound, "a tear in the social fabric, affecting a group of people that has achieved some degree of cohesion" (Eyerman, 2004, p. 61). The accompanying negative affects reveal that the event is perceived as a threat to the group's identity. An initial reaction of shock is followed by widespread collective mourning and efforts to commemorate the traumatic event (Smelser, 2004b, pp. 266-267). Cultural traumas are discursive constructions - various social actors reinterpret the meaning of the traumatic event, from the vantage point of different affected groups. In this perspective, the First World War as a cultural trauma dwells in the discourses created and contested over time (Smelser, 2004a, p. 37). Literature plays an important role in commemorating such events, as well as in reinterpreting and teaching the younger generations about the traumas of the past.
} 
In Toby's Room (2012), Pat Barker explores the issue of melancholic incorporation. In The Shell and the Kernel: Renewals of Psychoanalysis, Abraham and Torok develop Freud's concept of melancholia, claiming that incorporation occurs when loss is denied, which generates a melancholic fantasy of absorbing the lost other into the self (1994a, pp. 127-130). This causes a profound disorder on the level of self-consciousness. After she learns about the death of her beloved brother Toby, with whom she had an incestuous, sexual relationship, Elinor tries to numb her pain by painting, thus attempting to immortalise her brother in her art. In her case, "incorporation is the refusal to acknowledge the full import of the loss, a loss that, if recognized as such, would effectively transform" her (Abraham \& Torok, 1994a, p. 127). What is more, Elinor's excessive attachment to Toby as an ego ideal and the secret of their incestuous love must be deeply concealed to cover up affects that profoundly unsettle the protagonist (see Abraham \& Torok, 1994a, p. 131). In reference to Elinor, hauntology becomes genuine honte-tology, from the French honte, shame. ${ }^{3}$ Her refusal to mourn results therefore in the formation of what Torok calls a secret tomb inside the melancholic's mental topography, a psychic crypt, in which the object of loss is buried alive (Abraham \& Torok, 1994a, p. 130): “It's almost as if I'm turning into Toby. It's not just me thinking it either, other people have commented. As if you cope with loss by ingesting the dead person..." (Barker, 2013, p. 206; my emphases).

In Toby's Room, bereavement is disordered by Elinor's incestuous desires; she seems to suffer from what Torok has identified as the illness of mourning, which occurs when the death of a beloved person is accompanied by an increase in libido (Torok, 1994a, pp. 113-114). During the visit of her former lover, Elinor initiates sexual intercourse with Paul in Toby's room. From the beginning, the male protagonist experiences a weird sensation of a spectral presence. It is as if the young woman desired to be with him, but at the same time she desired somebody else:

But even in the most passionate moments - and there weren't many—Elinor had seemed to pull away ... Only he'd felt there was something else, a shadow falling across them, cast by something he couldn't see. He'd never known lovemaking like it. It had felt like a battle, not between the two of them - there'd been no antagonism—no, more like he was struggling to pull her out of a pit and sometimes she'd wanted to come with him, and at other times she'd turned back into the dark. (Barker, 2013, p. 107)

Elinor's desire for Toby through Paul's body shows that, as Torok explains, in the illness of mourning, the increase in sexual libido "is a desperate and final attempt at . . . a sudden amorous fulfilment with the object" (1994a, p. 117). Through incorporation, Elinor avoids accepting the loss of her brother, but also the loss of powerful desires that re-emerge at the moment of his death. If, eventually, at the end of the novel, the female protagonist abandons the melancholic crypt and opens up to Paul, a transfer of libido necessary in the evolution of melancholia into mourning (Freud, 1953-1974, p. 244), Barker insists on the

\footnotetext{
${ }^{3}$ This reflection was inspired by my reading of Ranjanna Khanna's "Fabric, skin, honte-ologie."
} 
persistence of Toby's haunting absence in the life of Elinor and her family. Thus, the author seems to suggest that being inhabited by the other - the departed - is a condition of dealing with excessive grief.

In Earth and Heaven (2000), Sue Gee also explores the haunting aspects of post-war grief caused by the loss of brothers and a whole generation of young men. For Walter Cox, the artistically talented protagonist of the novel, who was too young to enlist during the war, the death of his brother John William creates a void, an "emptiness [that] felt like the drop from the edge of a cliff" (Gee, 2000, p. 11). It makes him feel as if he lost half of his body (Gee, 2000, p. 62). For many years after the war his life is devoid of meaning and, like Barker's Elinor, he strives to construct an illusion of sense through art and love. Yet, the memory of the day when the telegram with the fatal news arrived continues to haunt him, his life forever "overshadowed" by the tragedy of war (Gee, 2000, p. 26). Similarly, his friend Euan Harrisson, a sculptor who was old enough to take part in the war, remains inhabited by the ghosts of comrades he lost at Passchendaele. In Gee's beautifully melancholic novel, the haunting trauma of loss is subtly evoked by images of empty fields, neglected farms, urban vistas filled with spectral figures of unemployed veterans. Moreover, Earth and Heaven affects the reader so deeply because the pain of bereavement, so far understated in the novel, becomes movingly tangible after the accidental death of Walter's six-year-old son in 1929. It is as if the heart-rending grief after the loss of the beloved child condensed the pain of war bereavements a decade after the conflict. The war memorial before which the villagers gather every Armistice becomes from now on the locus of the family's and the village's grief (Renard, 2013, p. 311).

While Walter thinks of Geoffrey, and via him of John William, "almost every moment" of his life, half of it spent in mourning (Gee, 2000, p. 292), his little daughter Meredith, born after the war, inherits the burden of traumatic memories. Surrounded by stories of death and an atmosphere of overwhelming grief since early childhood, she is prey to tormenting fantasies of violence and death, which refer to war's fallen heroes, but also function as a premonition of her brother's death (Renard, 2013, p. 241). Moreover, Meredith buries the little boy deep inside her (Gee, 2000, p. 386), succumbing to the fantasy of incorporation, and continues to talk to him every day. Later, she believes the Angel of Death in her father's painting has a malevolent power over her and her family. Consequently, in Gee's novel, the Great War "casts a long shadow" (2000, p. 209) over the generation who survived it but also over the generations that follow, in whom the dead continue to live a half-life. The Second World War, mentioned in parentheses at the end of Earth and Heaven, renders the completion of mourning impossible.

The haunting persistence of Great War memories is thematised by Sebastian Faulks in his Birdsong (1993), which juxtaposes two storylines: the first one is set before and during the First World War and depicts the devastating war experience of Stephen Wraysford and his love-affair with a married woman, whereas the second one, set in the late 1970s, focuses on the efforts of his granddaughter to understand his life. An unhappy thirty-eight year old woman, also involved in a relationship with a married man, Elizabeth Benson is 
not concerned with the First World War and does not know anything about her family's entanglement in the conflict, until she discovers her grandfather's coded journal, in the attic of her mother's house. When she reads an article in the newspaper on the sixtieth anniversary of the Armistice, she feels strangely disturbed: "it seemed to touch an area of disquiet and curiosity that was connected to her own life and its choices" (Faulks, 1994, p. 250). Elizabeth's preoccupation with the past can be interpreted in terms of phantomatic haunting elaborated by Nicolas Abraham, "the unremitting transmission of secrets of one generation to another" (Rand, 1994b, p. 169). Abraham explores the mental topography of excluded realities, people's deeply concealed secrets which are later inherited by their descendants and may disrupt their lives: "The phantom which returns to haunt bears witness to the existence of the dead buried within the other" (1994a, p. 175; italics in the original). The concept of the phantom redraws therefore the boundaries between self and other, past and present, "by suggesting the existence within an individual of a collective psychology comprised of several generations" (Rand, 1994b, p. 166).

In Birdsong, Elizabeth feels a special connection with her grandfather, whose war experience and personal tragedy were never mentioned in her family. Faulks thus problematizes the issue of silence - the unsayable family secret and the collective disregard for the national past - suggesting that "what haunts are not the dead, but the gaps left within us by the secrets of others" (Abraham, 1994a, p. 171). Troubled by the oppressive legacy of silence, Elizabeth researches the past in an effort to reconstruct her grandfather's life, but also to understand the present and herself:

What she described as a mild curiosity crystallized inside her to a set determination. Beginning with the contents of her mother's attic she would track this man down: she would make up for the lateness of her interest in him by bringing all her energy to the task. It would be one way, at least, of understanding more about herself. (Faulks, 1994, p. 250)

Importantly, although apparently Elizabeth is involved in an epistemological quest, Faulks denies any rational meaning to war. When Elizabeth reads about the Great War, she is overwhelmed by her ignorance and is incapable of forging any connection with the events of the past. She therefore decides to visit the battlefields and soldiers' cemeteries in France. Observing the Thiepval Memorial ${ }^{4}$ from afar, she is repulsed by its pretentious grandeur, yet reading on its walls the endless names of the dead soldiers whose bodies were never found, she feels deeply affected. Thus, Elizabeth's investigation leads her to facts, yet most importantly to emotions through which she makes contact with the traumatic past, "not as dispassionate knowledge but as an experience which, although incommunicable, may at least be approximated" (Klonowska, 2014, p. 175).

\footnotetext{
${ }^{4}$ For a detailed analysis of the representation of the Thiepval Memorial in Faulks's Birdsong and Barker's Another World, see Sokołowska-Paryż (2012, pp. 127-185).
} 
Her epistemological quest and acquisition of historical knowledge is necessary to lay the dead to rest, for

Reducing the "phantom" entails reducing the sin attached to someone else's secret and stating it in acceptable terms so as to defy, circumvent, or domesticate the phantom's (and our) resistances, its (and our) refusals, gaining acceptance for a higher degree of "truth." (Abraham, 1994b, p. 189)

Elizabeth's phantomatic connection with her grandfather might have unwittingly influenced her life choices so far, yet when she decides to have a child, she consciously intends to fulfil the promise Stephen gave to his comrade-in-arms, agonising in the tunnel after the explosion. The life of a woman in 1978 might be incompatible with the experience of her grandfather in the Great War but the ontological event of war, due to the powerful descriptions in the novel, as well as the interplay of contrasts and analogies, becomes less aporetic to the contemporary reader.

Esther Freud in her much less famous novel Summer at Gaglow (1997) also uses the theme of a pregnant woman who investigates the family secrets connected with the Great War. The narrative is split between the storyline focusing on Emmanuel, her German ancestor during the First World War, and Sarah's contemporary life in London. The female protagonist, who, like Elizabeth in Birdsong, has a problematic relationship with her partner, is the only person in her family who is haunted by the past and deeply unsettled by how little they know about it. Trying to make sense of it, she can only find some fragmentary stories; her Jewish family, miraculously rescued from the Holocaust, wish to forget about the painful events of the past which led to the loss of their property at Gaglow, in Germany. The pre-Holocaust family past, the First World War in particular, has been silenced and reduced to sordid anecdotes. Freud thus shows how the memories of Shoah have overshadowed those of the First World War; she also renders the unease German immigrants in Britain might feel about their German ancestors' participation in the 1914-1918 conflict. For Sarah, however, the recovery of the past is essential; she treats it as an heirloom vital for her son. At the end of the novel, the enigma is solved, although Sarah is not certain how much of the story was invented and how much is true.

Eventually, like in Birdsong, when the female protagonist makes sense of the phantoms surrounding her, Sarah's life regains order; she reconciles with her lover and together they travel to Gaglow, as, for inexplicable reasons, she feels a connection with the space inhabited by her family before the war. By attempting to understand her ancestors' undisclosed and long-forgotten suffering, Sarah lays the dead to rest and honours her bond with them, which allows her to regain control over her life. It is important to note that in both Birdsong and Summer at Gaglow, the female seeker's pregnant body assures that the past will be transmitted to a younger generation, a promise of redemption (Renard, 2013, p. 324), yet it might also be interpreted as a metonym of phantomatic haunting, the interiorization and retention of another's traumatic memory - the Freudian "foreign body" within (Breuer \& Freud, 2000, p. 6). 
In Another World (1998), Pat Barker offers perhaps the most disturbing vision of the spectral, long-lasting effects of the First World War. The power of the novel lies in Barker's study, "within a single narrative frame, [of] both the haunting effect of successive generations and the troubling relation between the violence of war and violence within the family" (Whitehead, 2004, p. 129). At the centre of the novel is the relationship between the main protagonist, Nick, a middle-aged husband and father, and his grandfather Geordie, a centenarian veteran of the First World War, who, eighty years after the conflict, seems to still suffer from PTSD and re-enacts frontline patrols, crawling through the streets at night with the agility of a young man. It is not as if he were remembering the war, but "actually seeing it" (Barker, 1998, p. 69); in Nick's opinion, Geordie's memories display a "hallucinatory filmic quality" (Barker, 1998, p. 241). Although the old man is diagnosed with cancer, he is convinced that the pain in his side is caused by the wound which he acquired in the war during a bayonet attack, which points to the persistence of the trauma of war, in both his body and mind: "The bleeding bayonet wound's the physical equivalent of the eruption of memory that makes his nights dreadful" (Barker, 1998, p. 227). At the end of the novel, it turns out, however, that the content of Geordie's traumatic memories is not only the cruelty of combat, but the murder of his brother Harry, whom he stabbed to death when he found him agonising in No Man's Land. Geordie is not certain whether it was an act of mercy or an outburst of sibling rivalry, as he was always envious of his brother and, as a child, often wished his death. According to Anne Whitehead, "His fear, which he takes with him to the grave, is that the war gave him the opportunity to act on a murderous impulse toward his elder brother, a 'child's hatred' that otherwise would have existed only in fantasy" (2004, p. 133). After he returned from the front, Geordie has obstinately refused to speak about Harry's death. ${ }^{5}$

Significantly, the trauma of fratricide permeates the novel and creates continuity between generations. In this sense, for his descendants, Geordie's secret traumatic experience becomes "a gap in the unconscious, an unknown, unrecognized knowledge" - the phantom the effect of which "can persist through several generations and determine the fate of an entire family line" (Abraham \& Torok, 1994b, p. 140). In a narrative that resembles a gothic ghost tale, Barker locates phantomatic haunting on both individual and collective levels, addressing the gothic question of family inheritance and the larger question of unresolved social guilt. In Another World, "the family unit, it seems, is constructed on lies and deception, and each generation guards its secrets from those who come before and after" (Whitehead, 2004, p. 138). Nick's complicated family life is governed by violent

\footnotetext{
${ }^{5}$ In Barker's novel, the old man is interviewed late in life by the oral historian Helen, who attempts "to get Geordie to frame his war experience in terms of late-twentieth century preoccupations. Gender. Definitions of masculinity. Homoeroticism" (Barker, 1998, p. 83), which he cannot really understand. He is also skeptical of the public rituals of commemoration as he is well aware of the fact that soldiers were not always motivated to fight for patriotic reasons. He also remembers with resentment how the veterans were abandoned to unemployment and poverty by a government unwilling to consider the devastating mental effects of the war. Helen is not aware of the fact that Geordie's deliberate isolation might have been caused by guilt about his brother's death (see Sokołowska-Paryż, 2012, pp. 170-171).
} 
tensions, which he refuses to acknowledge as he moves into a new house with his partner Fran, who is pregnant with another child, their toddler son Jasper, her eleven-year-old son Gareth, from an earlier marriage, and his own thirteen-year-old daughter Miranda, who must now live with them because her mother has been committed to a psychiatric ward. Jasper's life is constantly jeopardised by the deeply troubled Gareth and Miranda or maybe the ghost of another girl, who used to live in the house. Removing the wallpaper in one of the rooms, Nick's family finds an obscene portrait of the previous inhabitants of the house, the Victorian Fanshawes, whom they recognize as their sinister double (Barker, 1998, p. 41). Nick later discovers that the elder children in the Fanshawe family, Robert and Muriel, were accused of the murder of their younger brother, the offspring of a later marriage, and, although they were never sentenced for the murder, Robert implied their guilt in a letter to his sister, just before he was killed in the Somme offensive. Barker thus questions the stereotype of childhood innocence and seems to suggest that children might act on a motivation to murder. Muriel is the girl who haunts the house and fuses with Miranda, possessing her to assist Gareth when he tries to murder Jasper by throwing stones at him during the family outing at the beach. ${ }^{6}$ Furthermore, the novel resonates with allusions to real-life child murders, such as the Bugler case, Mary Bell's case, and others, thereby highlighting our sense of vulnerability in the social world. ${ }^{7}$

The concept of the phantom, as "a form of communication ... between the unconsciouses [sic!] of two persons" (Torok, 1994b, p. 178), proves particularly useful in the analysis of Another World. As Abraham suggests, although all dead may return, those who are destined to haunt are criminals or social outcasts, "the dead who took unspeakable secrets to the grave" (1994a, p. 175), like Geordie in Another World. In Barker's novel, Nick feels a special connection with Geordie; in fact, he displays emotional indifference or repulsion to other members of his family. During their visit to the war cemetery at Thiepval, Nick seems to absorb the haunting legacy of the war as well as his grandfather's secret, which he never disclosed during his lifetime:

Geordie was attempting to graft his memories on to Nick - that's what the visit was aboutand perhaps, in spite of Nick's resistance, he'd come close to succeeding. Something important happened to Nick at Thiepval and he'd never come to terms with it. (Barker, 1998, p. 74)

According to Abraham, the presence of the phantom in the descendant is the effect of a profound injury of the ancestor (1994a, p. 174). The haunted person reconstructs the secret

\footnotetext{
${ }^{6}$ Whitehead points out that the ghost of the blond-haired girl is ambiguous in the novel and the reader is uncertain whether the apparition is Muriel Fanshawe, the adolescent bully who persecutes Gareth, or Miranda herself (2004, p. 142). Piątek interprets this figure as a symbol of the transgenerational transmission of fratricidal desires (2014, p. 74). Nunn and Biressi also suggest that Muriel's spectral apparitions might be "an unconscious projection of the unspoken anger, aggression, desire, and malevolence that all the family members feel at different times for each other, but refuse to articulate or recognize in themselves" (2005, p. 261). Interestingly, in her analysis of revenants in Barker's novel Whitehead also deciphers the intertextual allusions to Henry James's The Turn of the Screw, thus highlighting the uncertain question of childhood innocence (2004, pp. 140-141).

${ }^{7}$ For a detailed analysis see Whitehead (2004, p. 144) and Nunn and Biressi (2005, pp. 254, 260), who also interpret the violence in the novel through the prism of the class factor (2005, pp. 262-264).
} 
in the form of unconscious knowledge, which manifests itself in uncontrollable behaviour, "showing and hiding that which, in the depths of the unconscious, dwells as the livingdead knowledge of someone else's secret" (Abraham, 1994b, p. 188; italics in the original). Eventually, the phantom seems to dictate Nick's sexual union with Helen, the cultural historian Geordie felt a romantic attachment to; this is suggested by the pervasive scent of Geordie's perfumes which accompanies the sexual act after his death (Barker, 1998, p. 266). In this light, Nick acts as if possessed by his grandfather's phantom; he is not entirely responsible for his own decisions (see Abraham, 1994a, pp. 173-175), "prey to strange and incongruous words or acts, transferred from events ... whose initiator was an other" (Abraham, 1994b, p. 188).

If, at the end of the novel, Nick seems to accept the burden of the past, expressing, at the same time, hope for a new order and cathartic purification - "the past never threatens anything as simple, or avoidable, as repetition" (Barker, 1998, p. 278)—Barker seems to caution the reader about "our need for a past that is neatly packaged and easily resolved" (Whitehead, 2004, p. 134). The eruptions of violence haunt Nick's family as a legacy of their bloodline, with gothic undertones of the sins of the fathers revisiting the sons. In a most unsettling perspective, Barker seems to suggest a connection between Geordie and the most troubled character in the novel - his great-grandson Gareth. The latter belongs to a generation addicted to horror films and violent computer games, which causes him to try to re-enact violence in real life. In Barker's novel, "The cinematic attributes of Geordie's memories are set alongside Gareth's immersion in computer games and movies and his resultant cinematic perception of reality" (Sokołowska-Paryż, 2012, p. 182). Gareth's favourite films and computer games "erode the difference between childhood and adulthood" (Nunn \& Biressi, 2005, p. 262) in a way that echoes the First World War, which, for young men barely out of boyhood, like his great-grandfather who went to war at seventeen, legitimized otherwise inconceivable brutality, disturbing the borderline between reality and childhood fantasies of violence, and thus corrupting their subsequent lives. As Nunn and Biressi point out, "the elision between the past familial murder and the present danger to Jasper fuses public and private trauma" (2005, p. 263) — in this sense, the phantomatic narrative of Another World implicitly suggests the persistence of violence as a legacy of the First World War, which haunts British society as an unresolved cultural trauma that has defined the twentieth century. The complex structure of the novel allows therefore Barker to explore, by means of phantomatic haunting, "the reality of violence as an integral part of human nature, social life and national history” (Sokołowska-Paryż, 2012, p. 166).

In their fictional visions of the Great War, contemporary British novelists examine the impact of the 1914-1918 conflict placing affect at the centre of their narratives. This tendency to exhibit a complex legacy of emotions "has been encouraged by a change in British expressive culture, which it has in turn reinforced, so that the public display of emotion is now not merely accepted but expected" in popular representations of the Great War (Todman, 2008, p. 433). At the same time, this fiction complicates the representation of the past by fathoming complex psychological processes and pathologies of memory and thus highlighting memory's "capacity to serve as a metaphor for a broader movement of 
uncertainty about how to frame the past" (Winter, 2001, p. 65). Although it is debatable whether the First World War remains Britain's "number one national ghost," as Ted Hughes claimed in 1965 (Renard, 2013, p. 13), haunting shapes to a large degree the practices of commemoration in Britain and hauntology proves a useful tool in the analysis of recent British First World War cultural productions. The persistence of melancholia, crypts and phantoms in this fiction exposes hidden social wounds and suggests that the First World War "remains in the collective memory as a persistent traumatic experience that has been insufficiently addressed or acknowledged" (Childs, 2005, p. 62). Barker, Gee, Faulks and Freud thus reinforce the futility myth, as defined by Samuel Hynes (1990, p. 439), which has shaped British representations of the Great War, yet they also expand the traumatizing interpretive framework, bringing their examination of the long-lasting effects of the 1914-1918 conflict closer to post-memory representations of the Second World War. Finally, bridging the present with the past, their fictions examine our most vital concerns today, offering fascinating insight into the enigmas of memory and mourning, private obsessions, the structure of family as well as our social vulnerabilities.

\section{Acknowledgements}

This research was supported by grant DEC-2013/11/B/HS2/02871 from the Polish National Science Centre (Narodowe Centrum Nauki).

\section{References}

Abraham, N. (1994a). Notes on the phantom: A complement to Freud's metapsychology. In N. Abraham \& M. Torok, The shell and the kernel: Renewals of psychoanalysis (pp. 171-176). (N. T Rand., Ed. \& Trans.). Chicago, IL: University of Chicago Press.

Abraham N. (1994b). The phantom of Hamlet or the sixth act, preceded by the intermission of 'truth'. In N. Abraham \& M. Torok, The shell and the kernel: Renewals of psychoanalysis (pp. 187-205). (N. T. Rand., Ed. \& Trans.). Chicago, IL: University of Chicago Press.

Abraham, N., \& Torok, M. (1994a). Mourning or melancholia: Introjection versus incorporation. In N. Abraham and M. Torok, The shell and the kernel: Renewals of psychoanalysis (pp. 125-138). (N. T. Rand., Ed. \& Trans.). Chicago, IL: University of Chicago Press.

Abraham N., \& Torok, M. (1994b). 'The Lost Object—Me': Notes on endocryptic identification. In N. Abraham and M. Torok, The shell and the kernel: Renewals of psychoanalysis (pp. 139-156). (N. T. Rand., Ed. \& Trans.). Chicago, IL: University of Chicago Press.

Alexander, J. C. (2004). Toward a theory of cultural trauma. In J. C. Alexander, R. Eyerman, B. Giesen, N. J. Smelser, \& P. Sztompka (Eds.), Cultural trauma and collective identity (pp. 1-30). Berkeley: University of California Press.

Audoin-Rouzeau, S., \& Becker, A. (2000). 14-18, retrouver la guerre. Paris, France: Gallimard.

Barker, P. (1998). Another world. London, UK: Viking. 
Barker, P. (2013). Toby's room. London, UK: Penguin Books.

Breuer, J., \& Freud, S. (2000). Studies on hysteria. (J. Strachey, Ed. \& Trans.). New York, NY: Basic Books.

Campbell, J. (1999). Combat gnosticism: The ideology of First World War poetry criticism. New Literary History, 30(1), 203-215.

Childs, P. (2005). Contemporary novelists: British fiction since 1970. London, UK: Palgrave Macmillan.

Eyerman, R. (2004). Cultural trauma: Slavery and the formation of African American identity. In J. C. Alexander, R. Eyerman, B. Giesen, N. J. Smelser, \& P. Sztompka (Eds.), Cultural trauma and collective identity (pp. 60-111). Berkeley: University of California Press.

Faulks, S. (1994). Birdsong. London, UK: Vintage Books.

Freud, E. (2009). Summer at Gaglow. London, UK: Bloomsbury.

Freud, S. (1953-1974). Mourning and melancholia. In J. Strachey (Ed. \& Trans.), The standard edition of the complete psychological works of Sigmund Freud, Vol. XIV (pp. 243-258). London, UK: Hogarth Press.

Gee, S. (2000). Earth and heaven. London, UK: Review.

Hynes, S. (1990). A war imagined: The First World War and British culture. London, UK: Bodley Head.

Khanna, R. (2008). Fabric, skin, honte-ologie. In C. Pajaczkowska \& I. Ward (Eds.), Shame and sexuality: Psychoanalysis and visual culture (pp. 159-179). London, UK: Routledge.

Klonowska, B. (2014). Longing for romance: British historical romances 1990-2010. Lublin, Poland: Wydawnictwo KUL.

Nunn, H., \& Biressi, A. (2005). In the shadow of monstrosities: Memory, violence, and childhood in Another World (pp. 254-265). In S. Monteith, M. Jolly, N. Yousaf \& R. Paul (Eds.), Critical perspectives on Pat Barker. Columbia: University of South Carolina Press.

Piątek, B. (2014). History, memory, trauma in contemporary British and Irish fiction. Kraków, Poland: Jagiellonian University Press.

Rand, N. T. (1994a). Introduction: Renewals of psychoanalysis. In N. Abraham \& M. Torok, The shell and the kernel: Renewals of psychoanalysis (pp. 1-22). (N. T. Rand., Ed. \& Trans.). Chicago, IL: University of Chicago Press.

Rand, N. T. (1994b). Editor's note. In N. Abraham \& M. Torok, The shell and the kernel: Renewals of psychoanalysis (pp. 165-169). (N. T. Rand., Ed. \& Trans.). Chicago, IL: University of Chicago Press.

Renard, V. (2013). The Great War and postmodern memory: The First World War in late 20th-century British fiction. Bern, Switzerland: Peter Lang.

Smelser, N. J. (2004a). Psychological trauma and cultural trauma. In J. C. Alexander, R. Eyerman, B. Giesen, N. J. Smelser, \& P. Sztompka (Eds.), Cultural trauma and collective identity (pp. 31-59). Berkeley: University of California Press. 
Smelser, N. J. (2004b). Epilogue: September 11, 2001, as cultural trauma. In J. C. Alexander, R. Eyerman, B. Giesen, N. J. Smelser, \& P. Sztompka (Eds.), Cultural trauma and collective identity (pp. 264-282). Berkeley: University of California Press.

Sokołowska-Paryż, M. (2012). Reimagining the war memorial, reinterpreting the Great War: The formats of British commemorative fiction. Newcastle upon Tyne, UK: Cambridge Scholars Publishing.

Todman, D. (2008). The First World War in contemporary British popular culture. In H. Jones, J. O’Brien, \& C. Schmidt-Supprian (Eds.), Untold war: New perspectives in First World War studies (pp. 417-441). Leiden, the Netherlands: Brill.

Torok, M. (1994a). The illness of mourning and the fantasy of the exquisite corpse. In N. Abraham \& M. Torok, The shell and the kernel: Renewals of psychoanalysis (pp. 107-124). (N. T. Rand., Ed. \& Trans.). Chicago, IL: University of Chicago Press.

Torok, M. (1994b). Story of fear: The symptoms of phobia: The return of the repressed or the return of the phantom? In N. Abraham \& M. Torok, The shell and the kernel: Renewals of psychoanalysis (pp. 177-186). (N. T. Rand., Ed. \& Trans.). Chicago, IL: University of Chicago Press.

Whitehead, A. (2004). The past as revenant: Trauma and haunting in Pat Barker's Another World. Critique, 45(2), 129-146.

Winter, J. (2001). The memory boom in contemporary historical studies. Raritan, 21(1), 52-66. 


\title{
Dermot Bolger's Ghosting the War
}

\author{
Aleksandra Kędzierska \\ Maria Curie-Skłodowska University in Lublin \\ am.kedzierska@umcs.pl \\ Received 11 February 2017; accepted 2 October 2017.
}

\begin{abstract}
Dermot Bolger's Walking the Road (2007) is a tribute to Francis Ledwidge (1887-1917), one of the greatest Irish poets of the First World War. Focusing on the life and afterlife of Ledwidge who, as depicted in Bolger's play, emblematizes the condition of other Great War combatants doomed to oblivion, this essay, concerned with the various functions of the deployment of ghosts in Bolger's drama, argues that spectrality can become an effective means of revealing the plight of the war dead: the unremembered, whose names were effectively erased from public memory and who, thus turned into homeless revenants, were forced into a continual involvement in the war from which they cannot escape, even after death. As a spectral witness who moves between pre-war Ireland and the world of the trenches, Bolger's hero makes one aware how similar these realities are. Furthermore, as a classic case of shell shock, he demonstrates the role of haunting in the narrative of trauma, identity and memory. Last but not least, whilst enhancing the gothic dimension of the war, Frank's perceptions, as well as his spectral discourse, not only contribute significantly to illuminating the enigma which he personified, but, by providing an insight into his search for himself, they convey the plight of truth seekers who grasp, yet never fully encompass the Irish experience of the war.
\end{abstract}

Keywords: Irish poetry of the Great War; Francis Ledwidge; hauntology; Dermot Bolger; trauma; remembrance; desensitization; nostalgia; past versus present; the unremembered. 
$[\mathrm{T}] \mathrm{o}$ tell a story is always to invoke ghosts, to open a space through which something other returns. (Wolfreys, 2002, p. 18)

If I am getting ready to speak about ghosts, it is in the name of justice.... (Derrida, 1994, p. xix)

In Ireland . . . all ghosts are political. (Mac Suibhne, 2008, p. 111)

\section{Forgotten Heroes of the War}

The interest in Ireland's involvement in the First World War, which grew dramatically towards the end of the twentieth century, brought with it the need of exorcising the ghosts of the Irish past. In his study of Ireland's war poets, Jim Haughey comments on this case of cultural amnesia in the following way:

For most of the twentieth century a general drawing-down of blinds prevailed over Ireland's role in the First World War. While Northern Irish Unionists commemorated the $36^{\text {th }}$ (Ulster) Division's service to Crown and Empire, across the border, nationalists, eager to promote their own myth of origin, found it politically inexpedient to acknowledge the sacrifices of the thousands of Irishmen who served in the British Army during the conflict. And so began the Great Amnesia whereby the memory of Ireland's war dead was effectively expunged from public memory. (Haughey, 2002, p. 61)

More importantly, in the opinion of Emilie Pine:

Within a nationalist context the Irish soldiers of the Great War have often been forgotten in the larger purpose of remembering Easter 1916 while in a unionist context the entirety of experiences of the Great War has been refined into the remembrance of the Battle of the Somme, July 1916. Thus, as Keith Jeffrey argues, the Irish soldiers who fought in the Great War were left on the margins precisely because they were not politically central to the new, independent Irish State, on the other hand there was the overdose of ceremonial remembrance of the Ulster Unionists. (Pine, 2011, p. 127)

After their return, many ex-servicemen who had joined up the British Forces were considered traitors and, since the end of the war coincided with the rise of militant nationalism which was hostile to veterans, they were viewed with suspicion, intimidated and persecuted. Many were afraid to speak of their war experiences as it could endanger their families (Byrne, 2014). The 35000 (Pine, 2011, p. 127) who did not come back from the war were even easier to be officially forgotten in a country which was "changed, changed utterly."

Over the last thirty years - due to the joint efforts of historians ${ }^{1}$ and writers - much has been done to expose the silent lies and reclaim that which Terence Brown described as "one of the great unspokens of Irish life" (Pine, 2011, p. 148). The theme of Irish participation in the Great War and its remembrance has been dealt with in many novels including

\footnotetext{
${ }^{1}$ Some of the illuminating works discussing Ireland's involvement in the Great War include Ireland's Unknown Soldiers (1992) by Terence Denman, Europe and Ethnicity: World War I and Contemporary Ethnic Conflict (1996) by Seamus Dunn and T.G. Fraser, Ireland: The 20th Century (1999) by Charles Townshend, Ireland and the Great War by Keith Jeffery (2000), and Ireland, the Great War and the Geography of Remembrance (2003) by Nuala C. Johnson.
} 
Jennifer Johnston's How Many Miles to Babylon (1974), Sebastian Faulks' Birdsong (1993), Sebastian Barry's A Long Long Way (2005) and The Secret Scripture (2008), or Tom Phelan's The Canal Bridge (2005). Amongst the playwrights who have responded to the challenge of history are Frank McGuinness with his Observe the Sons of Ulster Marching Towards the Somme (1985), Christina Reid (Tea in a China Cup 1983 and My Name, Shall I Tell You My Name? 1989), and Sebastian Barry (The Steward of Christendom 1995). Last but not least, there is Dermot Bolger and his Walking the Road (2007) which, like those others, proves that Ireland has become "a nation of 'active' remembering, where the past is [no longer] regarded as something over and done with, but very much alive in the present" (Satake, 2017, p. 78). Most tellingly, this "aliveness," "a potential to be resurrected in the endless present of the theatre," is, as Anthony Roche states, embodied in the figure of the ghost (Roche, 1991, p. 63) whose haunting presences emphasise "the performative nature of remembrance culture" (Pine, 2011, p. 3).

In perceiving haunting as a method of sociological research, A.F. Gordon's Ghostly Matters tackles the question of "how to understand modern forms of dispossession, exploitation, repression and their concrete impact on the people most affected by them" (2008, pp. xv, 7, 8). She defines "haunting" as an animated state in which a repressed, or unresolved social violence makes itself known (Gordon, 2008, p. xvi). As the "social figure" the ghost doubtlessly represents that "form" by which "something lost or barely visible, or seemingly not there ..., makes itself known or apparent to us in its own way" (Gordon, 2008, p. 8). Edyta Lorek-Jezińska's study on Hauntology and Intertextuality in Contemporary British Drama by Women Playwrights, which explores various aspects of cultural significance attached to the ghost, demonstrates that the ghost figure, which is after all "a strong and recurrent feature of Irish drama" (Roche, 1991, p. 63), amongst others "comes to signify the process of being haunted by the past, and by those who have been marginalized or silenced" (Lorek-Jezińska, 2013, p. 307). She thus proves that the study of the spectral can be effective as "the opening to the voices [like that of Ledwidge ] that so far have been neglected but which are allowed to surface or emerge in the gaps or contradictions created in the mainstream or dominant discourses" (Lorek-Jezińska, 2013, p. 307).

\section{Francis Ledwidge- “our dead enigma"}

It would seem that this hauntological perspective is particularly apt for the discussion of the issue of Irish involvement in the Great War, as dealt with by Bolger's memory play Walking the Road. The playwright retells the story of the life, death and afterlife of one of the "ghosts" of the Great War craving that their memory be restored by the country for which they gave their lives. This "ghost" is none other than Francis Ledwidge (18871917), one of the most tragic Irish soldier poets of the years 1915-1917. Although he was a supporter of the Irish Nationalist cause and the aspirations of those involved in the 1916 Easter Rising, he joined the British army - The Royal Inniskilling Fusiliers - and was involved in campaigns in Gallipoli, the Balkans and, finally, the Western Front. Described by Seamus Heaney as "our dead enigma" in which all strains of Irishness "criss-cross in 
useless equilibrium" (Heaney, 1979, p. 3), Ledwidge, to quote the Laureate again, does "represent conflicting elements in the Irish inheritance which continue to be repressed or unresolved" (Bolger, 2007, p. 4).

Writing about his fascination with Francis Ledwidge, Bolger confesses that the Slane poet was a guiding spirit in his own career and he always wanted "his ghost to haunt me" (2012a). In walking the roads of Ledwidge's life, Bolger pilgrimaged to the poet's home, edited various collections of his poems (Francis Ledwidge: Selected Poems, 1999; The Ledwidge Treasury, 2008; Francis Ledwidge. Selected Poems, 2017), each with an Introduction by Seamus Heaney, and an Afterword by the editor). He was even invited to unveil the poet's monument in Flanders; this event led to the writing in 2007 of Walking the Road, commemorating the ninetieth anniversary of Ledwidge's death in the War.

\section{A New Type of the War Play: Objectives of Analysis}

Bolger's, Satake argues, is a new type of World War One play, "not even included in Kosok's categories," which, after all, detail all essential aspects of the war:

It does not simply represent, interpret, empathize with or use the war as an analogy for a contemporary situation, but is in itself an act of atonement, call it a commemorative play but in a spiritual and active, almost religious, sense. Here the play's performance is an act of remembering, which in turn is an act of redemption. We, together with the soul of Francis Ledwidge, remember the soldiers who are our fathers, grandfathers and great grandfathers, as they march towards each one's home. In Walking the Road individual memories become a collective memory for the audience without erasing the individuality of each with its unique story. (Satake, 2017, p. 80)

Walking the Road retrieves the poet from the limbo of "never having [his] story publicly told" (Bolger, 2012b). Cast as Frank, a trench world-ghost, Ledwidge is given a chance to throw some light on the complexities of his Irish self, as well as on the desperation with which, walking the many roads of his past, he strives to find the one that leads to forgiveness of the people who no longer seem to recognise him as one of their own. This journey home, the one place which nothing can disparadise, is Frank's atonement, a search for the blessing he needs to be granted, absolution for the sins which, in his own conscience, he does not feel he committed.

Sadly inconclusive, this search seems to begin in earnest, paradoxically, only after Frank's demise, which also marks his progression towards an understanding of himself, a trial which he undergoes in an almost Heideggerian manner, projecting his life onto the horizon of death. This "repetitive confrontation with what has been repressed and forgotten, [and] what has become invisible" (Lorek-Jezińska, 2013, p. 24) seems to be a metaphor for haunting, which Wolfreys perceives "as an essential aspect of being" (2002, p. 18).

Focusing on Ledwidge's unfulfilled desire to come back, which emblematises the condition of other Great War combatants doomed to oblivion, this essay, concerned with the various functions of the deployment of ghosts in Bolger's drama, argues that spectrality can become 
an effective means of revealing the plight of the war dead: the unremembered, whose names were effectively erased from public memory and who, thus turned into homeless revenants, were forced into a continual involvement in the war from which they cannot escape, even after death. As a spectral witness who moves between pre-war Ireland and the world of the trenches, Frank makes one aware how similar, due to entrapment and power struggle, these realities are. Furthermore, in a classic case of shell shock, he demonstrates the role of haunting in the narrative of trauma, identity and memory. Last but not least, whilst enhancing the gothic dimension of the war, Frank's perceptions, as well as his spectral discourse, not only contribute significantly to illuminating the enigma which he personified, but by providing an insight into his search for himself, convey the plight of modern truth seekers who grasp, yet never fully encompass the Irish experience of the war.

\section{Establishing the Ghosts' Presences: A New Dimension of the Lost Generation}

Having awakened after death, Frank's ghostly self relives various moments of his pre-war and trench existence. Representative of the many who are forced into oblivion, Frank is the ghost who not only has a history, but is himself history (Ratmoko, 2006, p. 1). Never alone in his plight, he has by his side a Proteus-like Companion, the only other character in the play and one who, depending on the situation, transforms (like Frank) into the ghosts of other people Frank used to know or met. Amongst them there are Frank's beloved Ellie, his younger brother Joe (by far the most frequent impersonation), a young German killed in the trenches, the fellow poet Tom Kettle, even a Francis Ledwidge (sic!) from Dublin, and, last but not least, a host of souls of the dead from various countries and continents. It is in response to their questions and pleas, but, above all, due to his need to come to terms with the various recollections he sees in his mind's eye, that Frank, disoriented and confused, can recreate his inverted Bildungsroman, which moves back and forth in place and time. As his memories unfold, they arrange themselves into a (ghost) ${ }^{2}$ story about, first, Lance and then, about Corporal Francis Ledwidge, portrayed in his complexity as a soldier poet, patriot and family man. Underpinning each aspect of his spectral autobiography, haunting and death emerge as the key metaphors defining the concept of Irishness / Irish history depicted in the play.

Due to the in medias res convention deployed in the play, the viewers are not instantaneously aware that the two characters on the stage, Frank and Companion, are ghosts. And yet, the opening stage directions accentuate their deadness. Frank is described as "motionless, eyes staring out lifelessly" (Bolger, 2007, p. 15). Lifelessness, cold and/or numbness are also characteristics of his Companion. Occasionally, the protagonist informs his interlocutor: "I'm dead" or explains, as Frank does to the ghost Ellie, that he is unable to see her apparition because his "eyes remain mortal even in death" (Bolger, 2007, p. 69).

\footnotetext{
${ }^{2} \mathrm{C}$. Clover argues that the ghost story might have such elements as "ghosts, a concern with trauma, with history, with class, with inheritance, a sense of terror and horror." See Men, Women and Chain Saws: Gender in Modern Horror Film (1992). See also Jack Sullivan, Elegant Nightmares: The English Ghost Story from Le Fanu to Blackwood (1978).
} 


\section{Spectral Parade}

When he finally comes to terms with his death, Frank becomes aware of thousands of other ghosts who, like himself, keep walking home. Their spectral "parade," one of the climactic, and most heart-rending, scenes of the play, demonstrates a new dimension of this war generation: "lost," not just because of the tragic waste of lives, but due to the indifference of their people whose unremembrance does not allow the dead to find peace: there is no resting place for the unreclaimed.

In Walking the Road ghosts are indeed a prominent and dynamic presence which, underscoring their communal nature, points to what Kathleen Brogan describes as "a historical consciousness of a people" (1998, p. 28). This presence becomes all the more significant due to their role as protagonists, narrative agents of their experience, and performers in/of the tale of their failed/lost lives. Their multiple impersonations as well as narratives are best rendered in the scene when Frank encounters other eternal stragglers. These errant ghosts acknowledge his presence and choose him (and / or his Companion) to be their spokesman, thus enhancing Frank's (and/ or Companion's) role as Everyman, the epitome of the war sufferer. The audience can hear the words of grief articulated through $\mathrm{C}$ (Companion) or F (Frank) who, at first, face each other:

F: "My name is Wolfgang and I am walking home". "My name", [says another] "is Hans and Gunter and Gabriel." C: "My name is Alasdair, and Alexander, and Dirk and Dieter."

F: "My name is Frederic and Flavio and Fritz and Felix." (Bolger, 2007, p. 60)

After a while, however, they turn to address the audience:

F: "My name is forgotten by every living being. I have lost my legs and arms.

C: "The mustard gas in my lungs still burns, even though my lungs were eaten by worms."

F: "I am the unremembered great uncle whose features you inherit."

C: "I live on in my laugh that only you possess."

F: "During lovemaking I am reincarnated inside your sharp intake of breath."

C: "You are not walking home alone, Frank."

F: "No, I sense thousands walking, a great host in tattered uniforms" (pp. 60-61)

No accusations, no anger, no craving for revenge, not even a plea for attention and remembrance - merely a catalogue of examples of the "pity of war distilled," affecting all those scarred by the war: Wolfgang, Flavio and Gabriel. Stressing the blood ties that run through them as well as using the real names of the soldiers representing different sides of the conflict, Bolger poignantly reminds the audience of their membership in the human family that knows no nationalities or borders (Satake, 2017, p. 84).

Permeated by pity, this orchestrated manifestation of the dead (Davies, 2007, p. 2) produces "a narrative illusion of characters and plot in front of the audience" who, Roche posits, "together shape a symbolic plane of shared imagination out of this foundational 
illusion" (Roche, 2015, p. 189). On this plane, the living who cannot but allow the haunting, can finally hear the message about the plight of the war dead and hopefully try to put an end to it. Moreover, this haunting enables the audience to realise "how emphatically didactic figures" the ghosts are, and how their visitation, "due to [its expected] transformative effects ... emerges as a pedagogic event” (Miller, 1997, p. 328). Francis O’Gorman argues that, being the "posthumous function of the behaviours of the once-living," the ghosts come with a mission "to change the living too, to draw out a kindly spirit of humanity and to release the life that was not. [Thus, the spectres] reinvent the notion of moral awakening because they are its agents. ... By them are the living quickened" (2010, p. 261).

Without a doubt, the participants of the spectral parade are all "figures of unresolved past" (Deane, 1974, p. 13; Martinovich, 2012, p. 1), and hence, as Kathleen Martinovich has it, they can be seen as "a means by which Ireland's history, especially the one that does not fit into the official narrative of Nationalism versus Unionism, can be accessed and assessed" (2012, p. 13). More significantly, even though no actual criticism of the status quo (of how cruelly the war dead are forgotten) is verbalised, the ghosts' very appearanceFrederick Jameson argues - calls "for a revision of the past, for the setting in place of a new narrative" and "reinvention of our sense of the past" (2008, p. 43). It is from this ethical imperative - calling "for a something to be done" - that, as Gordon posits, "comes a concern for justice" (2008, p. 194), a call which, as defined by Martinovich, involves acting "by way of the practice of mourning and remembering and [acknowledging] the part haunting plays in everyday social life" (2012, p. 13).

\section{The Haunting and the Haunted}

Although the spectres have no way of knowing if, or to what extent, their haunting will truly affect the audience, Frank's communion with this myriad of the war dead allows him to eventually accept his own death which, after two aborted attempts, he is finally able to relate to. Their stories give him the courage to cope with the horror for which he prepares by expressing the wish for "someone to find my remains: a splintered skull, and some buttons, two rows of teeth biting into a rusted identity tag" (Bolger, 2007, p. 59). The very description of his being blown to bits by a stray shell (suppressed for so long that it is offered just before the play's end) constitutes the ultimate proof of his being a ghost. "We were laying planks across thick mud," he recalls,

Next thing I was flying through the air, gazing down at men below gathered round my shattered limbs. A stray shell. . . . Then I was soaring up, warm air beneath my feathers. And I wasn't alone. Our father was there and our brother Patrick and Ellie and the faces of men from Australia and Belfast and Antwerp and Berlin drawing me towards them. (Bolger, 2007, p. 68)

"I'm a ghost, Joe," Frank finally confesses to Companion who in turn replies: "And what do you think I am?” (Bolger, 2007, p. 69). 
In fact, Frank earned his spectral status when he was still alive, after a nightmarish ninetymile march to Salonika when, "zombiefied" from exhaustion, the soldiers resembled "a line of walking ghosts." "Nobody," it was emphasised, "could survive walking the road" (Bolger, 2007, p. 18). Well-versed in the theatre of war, Frank's ghost realises that he is a case of shell shock (Bolger, 2007, p. 67) whose symptoms he recognises only too well: feeling hypnotised, not knowing who and where he is, talking to himself, suffering from frequent memory lapses and confusion (Landsburg, 1977, p. 67; Winter, 2000, pp. 7-11). With his national insignia indistinguishable in what "must have been a uniform once" (Bolger, 2007, p. 15), Frank has "no sense of where I am or who I am" (p. 19). He cannot even tell how old he is (p. 69) or why the war broke out. He does not always recognize his Companion- "Who are you again?" (pp. 19,65), he enquires every now and then-and is not even sure if he is Irish (p. 21). There are times he definitely thinks he is "going mad" (p. 20). Most telling, though, is his refusal to acknowledge certain facts: "I don't want to know," he claims, or "I don't remember... I don't want to remember. I keep trying to forget" (p. 56). Even more tragically, it turns out that the trauma does not seem to disappear after death; it just continues, deepening the soldier's identity crisis and weakening his reliability as a narrator, already undermined by his travelling through different time zones ("into when he was 9, 19, or 29"; Bolger, 2007, p. 56), yet never staying long enough in one place to offer more than a fragmentary recollection of events. For this reason his haunting can neither be deliberate nor determined; it just happens and seems to derive from the helplessness of the never-ending plight of entrapment in war and his need to liberate himself from the dread he has internalised and come to personify. In fact, Frank and Companion are quite vulnerable, and frequently haunted themselves. Every bend of the road home "calls out to them" (p. 40), but it merely seduces them into making another futile circle. Frank pleads with Ellie not to "steal the peace of my mind" and not to "torment" him (p. 32). Joe, in turn, is oppressed by the innocence in the face of Frank's younger self, haunted by the knowledge of the horrors it will have to absorb. Frank, too, is plagued by the faces when these happen to look at him from the tattered sacks used for bayonet practice; the exercise during which he "kills" not Germans, but the Irish from his past. More alarming still is his confrontation with the sight of "my own face haunting me" (p. 53).

In Walking the Road, Frank's death in war is the structural beginning of his tale which leads backwards into life, experienced in No Man's Land through occasional flashbacks. As these time journeys do not occur in a chronological order, they merely highlight the chaos of his spectral existence, reflecting his inability to cope with his past and the confusion with the present, which cannot seem to lead to a certain future. Frustrated by his fate, Frank enquires,

Why am I standing there trapped in the eternity of one second? I can't go forward, yet I can't go home. ... I'm twenty nine years old, I'm nineteen, I'm nine. I'm continually walking back through time, seeking the moment when I feel safe, when I'll glimpse a woman who will cure my hunger. (Bolger, 2007, p. 56) 
The only woman who can embrace his dire need to belong is his "Mama," accepting her son regardless of his radical choices; even a memory of her smile envelops him with love and enables him to feel alive again. However, as will be shown, Mother Ireland is a very different story.

\section{Spectral Spaces: Ghostly War and Ghostly Ireland}

When reminisced about in Flanders, Ireland seems as distant as "another lifetime," yet not even his homesickness can erase Frank's bitter taste of oppression which he was doomed to experience in both places. His sergeant's command: "It's bayonets on, lads! Charge!" (Bolger, 2007, p. 54) triggers one of the many parallels between the soldiers' actions at home and in Turkey.

We charged through cheering crowds on the Dublin quays. We charged up the beaches at Suvla Bay into the teeth of Turkish guns at Gallipoli. We crouched in crumbling holes in the sand and rose and charged and then retreated amid the slaughtered bodies. We charged and charged as the battle fronts changed. What never changed were our screams during each bayonet charge. (Bolger, 2007, p. 54; emphasis added)

When interpreted through the prism of the various meanings of "charge," life, even at its most carefree never sheds its underpinning of feverish haste, of prices to be paid, or of an alertness to the danger of attack.

Stuck in his trench ("like insects under glass"; Bolger, 2007, p. 37), meditating on the pervading sense of entrapment which he was also exposed to at home, he despises himself for being like "a blind mouse tussled up in a grain sack, scurrying with no way in and no way out" (Bolger, 2007, p. 58). Ireland is "innuendoes, whispers and taunts" (p. 46), a "goldfish tank of a place" (p. 46) where every man "has a label for me: pro-German, coward, traitor, failed lover" (p. 50). Written off by Dublin literati because of his peasant roots and "for trying to be something he wasn't" (p. 44), he is further ostracised (even beaten up) for fighting under the British flag, while his British sergeant treats him like dirt, using invectives rather than his name: "Bloody Irish," "Paddy," "Bloody poets" (p. 33), constantly threatening him with punishment or death. Frank cannot afford to mention his amnesia, because in this army it is cured "with a bullet-especially if you're Irish" (p. 21).

Never one to be pampered by his country, he was "sacked at twenty for leading a strike, stooping in farmers' fields" (Bolger, 2007, p. 43) and then finding the only work he could hope for-mending roads. Sick as he is "of the smell of asphalt and drinking tea from a scalding billycan in the rain" (p. 46), he continues to build roads in No Man's Land and, ironically, it is while doing this job that he meets his death: "We were building a road amid the screams of dying and drowning men. We paused for tea and then. . " (p. 56).

Apart from this recollection, Frank is haunted by the ghostly, scarred landscape (Bolger, 2007, p. 37) whose horrid sights linger behind the eyelids, adding to the nightmare of the war even during sleep: "Famished, ghost-like looking children yearning for bread" (p. 17); 
"The smell of trench rot, cold terror of men sinking . . . in the mud till they slurped from sight" (p. 22); the presence of rats "who'll gnaw through your boots while you sleep" (p. 33), or surprise one with a gift "of a half-chewed hand" (p. 37). Whole woods are gone, reduced to merely "the few trees left standing" (p. 36). If the guns go silent, the "unearthly silence" pitilessly exposes one to far more frightening noises: "the screams of the unsaveable" (p. 27) "to finish them off as you pass ..., while you scrambled in terror over the dead and the dying" (p. 16). The spectres still recall the experience of their bayonets "getting tangled in the ribs of dying men. Lads tugging, amid the spew of guts, to retrieve their rifle and run on through the mud, terrified and terrifying inhuman and yet all too human" (p. 54).

Even though exposure to such sights (and sounds) may result in a soldier's desensitisation to suffering, at the same time it makes him strangely vulnerable, creating a desire for "someone to hold me amid the bullets screaming" (Bolger, 2007, p. 59). Surprisingly, even poetry has its share in No Man's Land anguish. When a soldier poet dies, his verses turn into "a confetti of words," "evaporating [and] fluttering out of sight" (p. 68). If, sometimes, they happen to survive, they are merely ghosts, shadows of what they were, "scraps [of poems] lost in the trenches, caught on barbed wire, too saturated with rain to be legible" (p. 55).

\title{
The Ghostly Trajectory: "beginning by coming back"3
}

The last episode of the play focuses again on Frank's memory of walking the road. The seasoned soldier is talking to his young self, again at sixteen, sharing with him the wisdom of the man who, despite the horrors he has experienced, has not forgotten the magic walk home with his first poem:

\begin{abstract}
you are afraid now to face your mother, but one day you'll have to face bodies being blown asunder, you will see love torn from you. You will wake in flooded trenches, having dreamed of home; the first poem will lead to others and make you never truly fit in anywhere again, you will be pinned down in the baked Gallipoli sands, freeze and Serbia and then, with your body crippled, be packed off again to Flanders, a cheap meat for the slaughter. That's where your poem will lead, lad. But even if you knew this, you would still walk this road for the magic feel of writing. (Bolger, 2007, p. 66)
\end{abstract}

Nevertheless, it is not only for the magic feel of writing that Frank the ghost continues walking: there is no place for him in Ireland "except on the roads" (Bolger, 2007, p. 55). His walking, often in circles or retracing the previous paths, constitutes the most essential action in the play and one that has been taking place for ninety odd years. Ninety miles to Salonika, forty two miles from Slane to Rathfarnham and Dublin, and back again. Many, many times. At sixteen he could not have guessed that, passed through at night, "quiet as the land of the dead" (p. 41), these isolated places would become part of the vast cemetery of No Man's Land. Like himself, they have turned into ghosts of the past, irrevocably lost,

\footnotetext{
${ }^{3}$ Derrida as cited in Lorek-Jezińska (2013, pp. 38, 302).
} 
alien signifiers which, nevertheless, still have a haunting power of sheer poetry. The map of these isolated towns is imprinted in his heart and mind, and "beyond tiredness," he can "just keep walking, carrying an uncertain gift of this first true poem” (p. 42).

Finally, there is the home. Frank sees his cottage, so vividly remembered and yet unreachable. The last scene of the play shows him almost there, close enough to hear his mother softly speaking his name. He has time to realise that "our cottage looks so dark" (Bolger, 2007, p. 69), and then the field near the house "spreads to infinity" (p. 70), distancing him again from all he loves and cherishes, tormenting him again by letting him look at what is no longer within reach. How could something as tangible as home suddenly turn into its ghost?

\section{Conclusion}

If one multiplies Frank's personal trauma by the myriad of fates of the unremembered dead of the Great War, one can perhaps imagine the scale of the plight Bolger merely touches upon portraying through the last journey of Francis Ledwidge the fate of the spectres who still fight their battles for the dignity of remembrance. Even if No Man's Land is almost forgotten, “despite everything, ghosts remain.” Even, as Schenstead-Harris argues, "if they cannot be seen to do so" (2015, p. 6).

As Bolger's play ends with Frank on the road, the shape used to "figure memory" (Satake, 2017, p. 79), his ghost neither permits nor is allowed closure (Lorek-Jezińska, 2013, p. 302). Like the Wandering Jew, he seems to exist for the purpose of reconstruction, of coming to terms with, and retelling, his experience: the soldiering of an Irishman in the British Army.

In 2007, when Ledwidge's poetry was known by the few, his haunting did open a space of awareness which, after a long wait made his voice heard in the mainstream. In 2017, the year of the centenary of his death, the whole nation was commemorating the poet whose achievements had finally been widely recognised. Does this mean that Ledwidge finally found the forgiveness he had so desired from Mother Ireland?

\section{References}

Bolger, D. (2007). Walking the road. London, UK: New Island.

Bolger, D. (2012a). In search of Ledwidge. DermotBolger. Retrieved May 15, 2016 from http://www.dermotbolger.com/article_francisledwidge.htm

Bolger, D. (2012b). Walking the road. Retrieved July 7, 2015 from http://www.dermotbolger.com/plays_walkingtheroad.htm

Brogan, K. (1998). Cultural haunting: Ghosts and ethnicity in recent American literature. Charlottesville: University Press of Virginia. 
Byrne, E. (2014, April 5). The forgotten Irish soldiers who fought for Britain in the First World War. The Guardian. Retrieved August 10, 2015 from https://www.theguardian.com/world/2014/apr/05/irish-soldiers-who-fought-for-britain

Clover, C. (1992). Men, women and chain saws: Gender in modern horror film. London, UK: BFI.

Davies, O. (2007). The haunted: A social history of ghosts. Basingstoke, UK: Palgrave Macmillan.

Deane, S. (1974). The writer and the Troubles. Threshold, 25, 13-17.

Derrida, J. (1994). Specters of Marx: The state of debt, the work of mourning and the new international. (P. Kamuf, Trans.). New Yor, NY: Routledge.

Gordon, A. F. (2008). Ghostly matters: Haunting and the sociological imagination. Minneapolis: University of Minnesota Press.

Haughey, J. (2002). The roses are torn: Ireland's war poets. In F. Bearton \& A. Gillis (Eds.), The Oxford book of modern verse (pp. 61-78). Oxford, UK: Oxford University Press.

Heaney, S. (1979). In memoriam: Francis Ledwidge. In S. Heaney, Field work. London, UK: Faber and Faber.

Heaney, S. (2007). The introduction. In D. Bolger (Ed.), The Ledwidge treasury: Selected poems of Francis Ledwidge (pp. 3-14). Dublin, Ireland: New Island.

Jameson, F. (2008). Marx's purloined letter. In M. Sprinker (Ed.), Ghostly demarcations: A symposium on Jacques Derrida's Specters of Marx (pp. 26-67). London, UK: Verso.

Landsburg, A. (1977). In search of strange phenomena. London, UK: Corgi.

Lorek-Jezińska, E. (2013). Hauntology and intertextuality in contemporary British drama by women playwrights. Torun, Poland: Nicolaus Copernicus University Press.

Mac Suibhne, B. (2008). Afterworld: The Gothic journey of John Gamble (1770-1831). Field Day Review, 4, 63-114.

Martinovich, K. M. (2012). A Poetics of ghosting in contemporary Irish and Northern Irish drama (Doctoral dissertation). University of Minnesota.

Miller, A. H. (1997). The spectres of Dickens's study. Narrative, 5(3), 322-341.

O'Gorman, F. (2010). The Cambridge companion to Victorian culture. Cambridge, UK: Cambridge University Press.

Pine, E. (2011). The politics of Irish memory. Performing remembrance in contemporary Irish culture. London, UK: Palgrave Macmillan.

Ratmoko, D. (2006). On spectrality: Fantasies of redemption in the Western canon. Frankfurt, Germany: Peter Lang.

Roche, A. (1991). Ghosts in Irish drama. In D. E. Morse \& C. Bertha (Eds.), More real than reality: The fantastic in Irish literature and the arts (pp. 41-66). New York, NY: Greenwood Press.

Roche, A. (2015). The Irish dramatic revival: 1899-1939. London, UK: Bloomsbury. 
Satake, A. (2017). Two Irish plays of the Great War: Frank McGuinness's Observe the Sons of Ulster Marching towards the Somme and Dermot Bolger's Walking the Road. Language, Culture, and Communication, 9, 67-85.

Schenstead-Harris, L. E. (2015). About telling: Ghosts and hauntings in contemporary drama and poetry (Doctoral dissertation). University of Western Ontario, London, ON. Retrieved June 21, 2016 from http://ir.lib.uwo.ca/etd/3091

Sullivan, J. (1978). Elegant nightmares: The English ghost story from Le Fanu to Blackwood. Athens: Ohio University Press.

Winter, J. (2000). Shell-shock and the cultural history of the Great War. Journal of Contemporary History. Special Issue: Shell-Shock, 35(1), 7-11.

Wolfreys, J. (2002). Victorian haunting: Spectrality, Gothic, the uncanny and literature. Basingstoke, UK: Palgrave. 



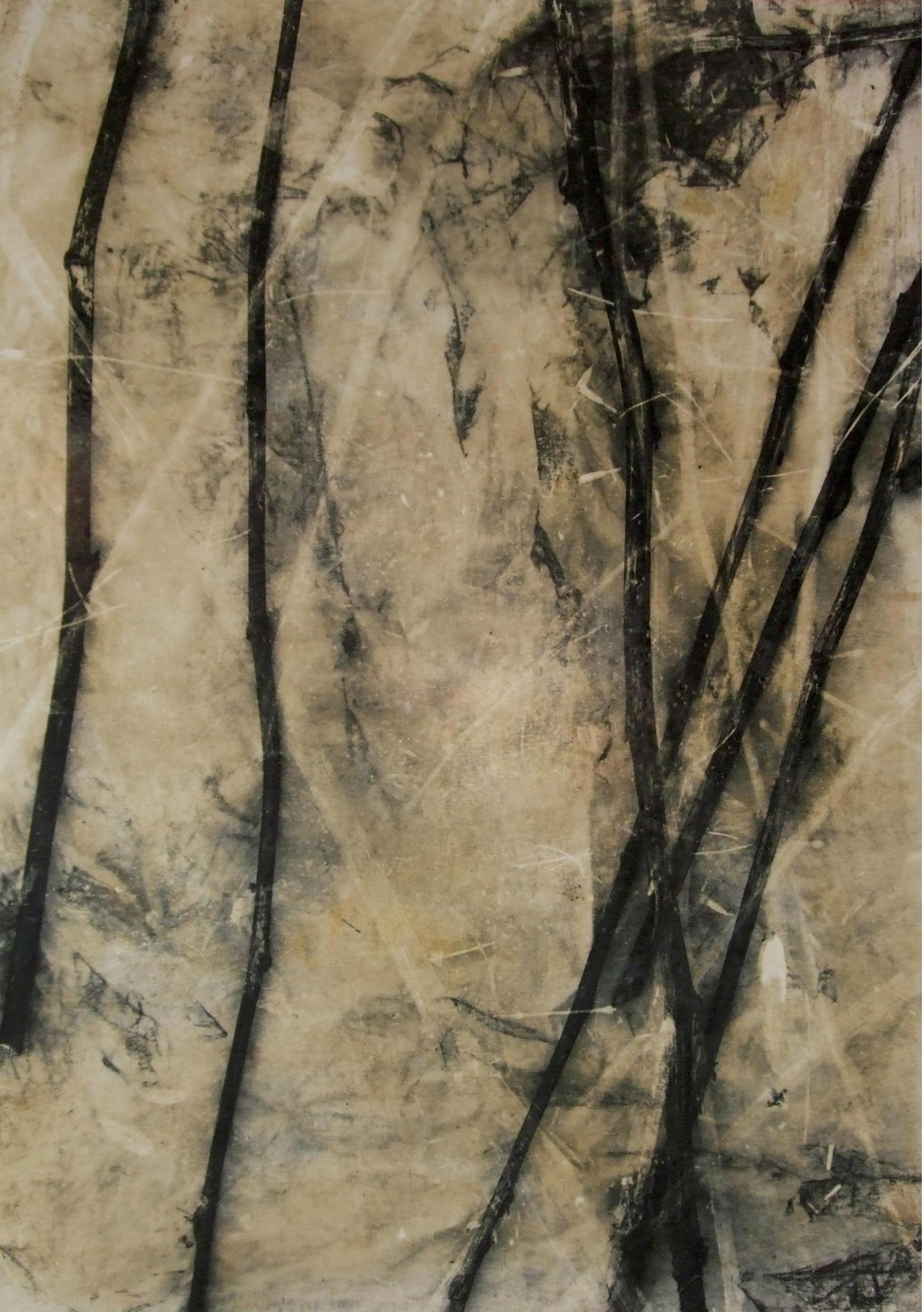


Anna Kola, from the series Plants, mixed media (toned photograph, resin), 100x70 cm, 2007 

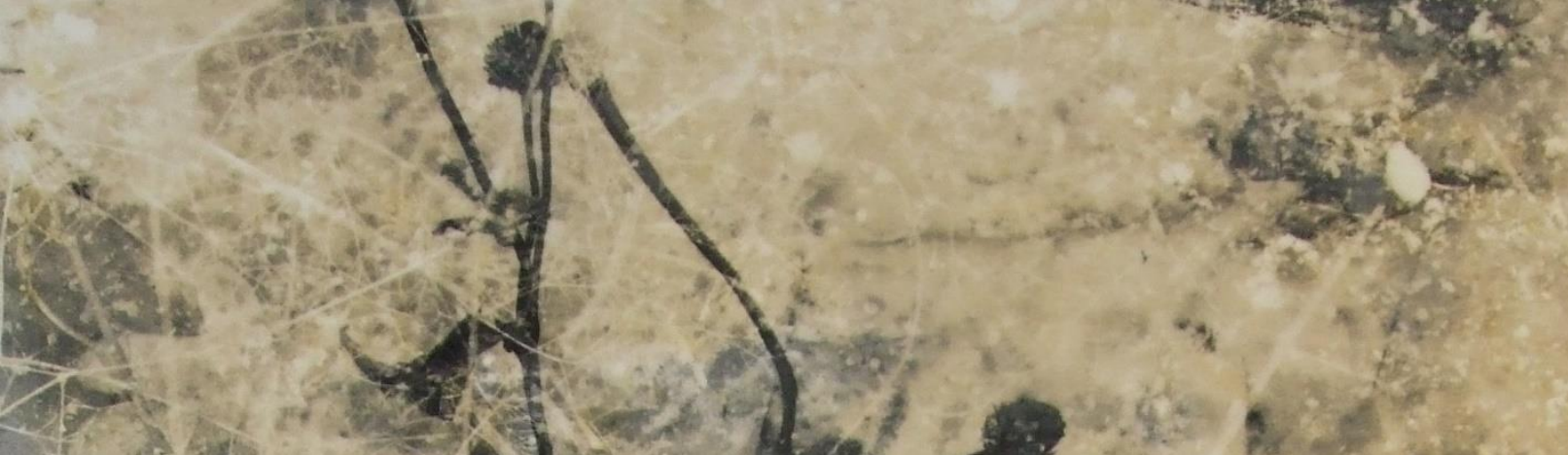

(1) 101

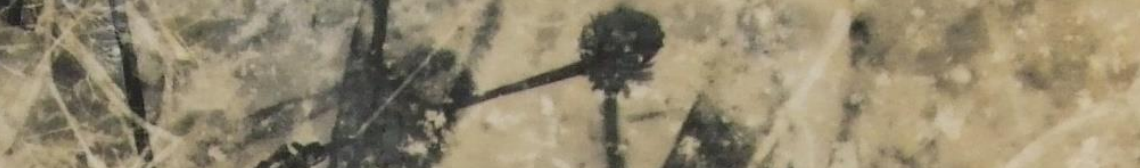

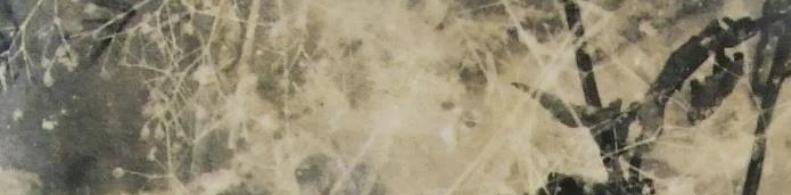

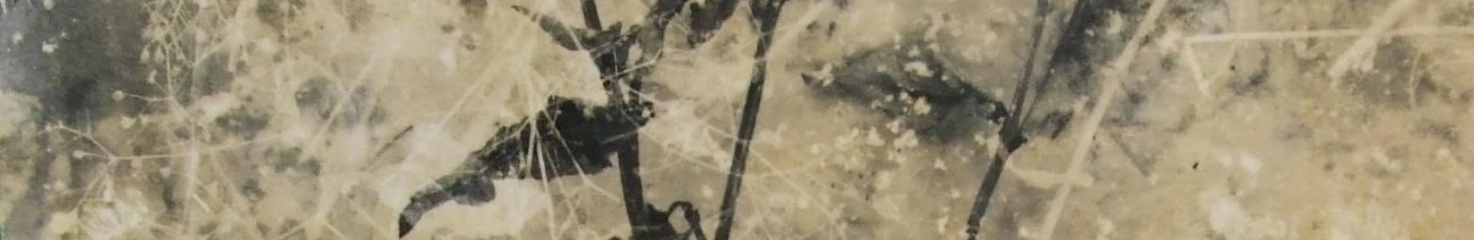

$x^{2}$

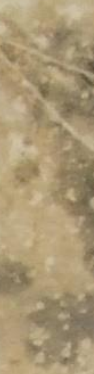

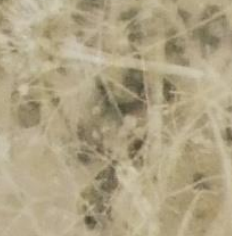

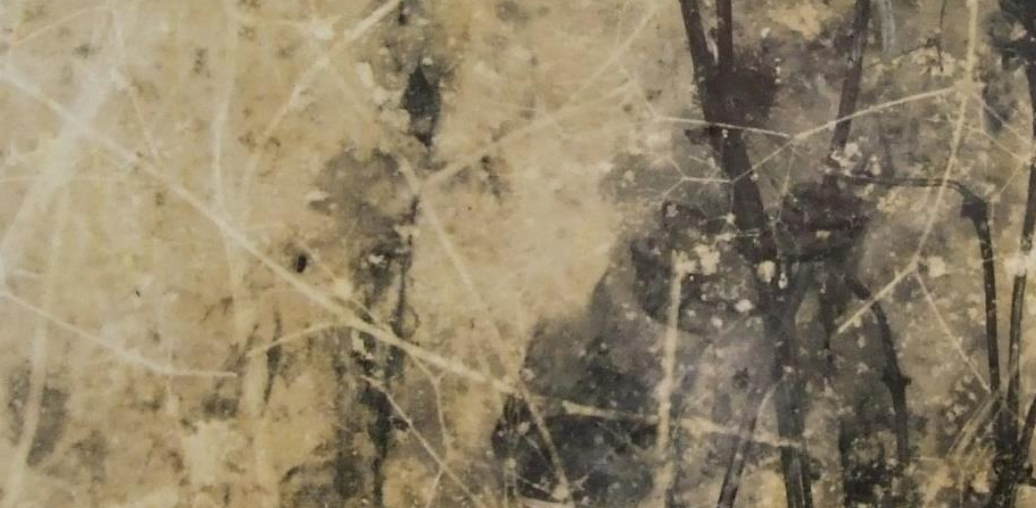

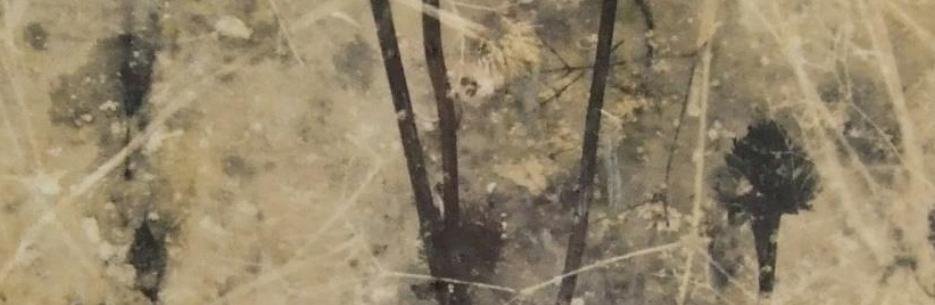
$+\frac{2}{4} e^{3}$<smiles>CCC(C)C1CCCC1</smiles>

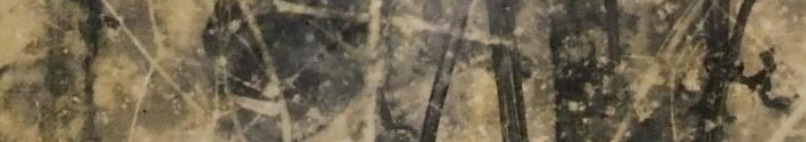

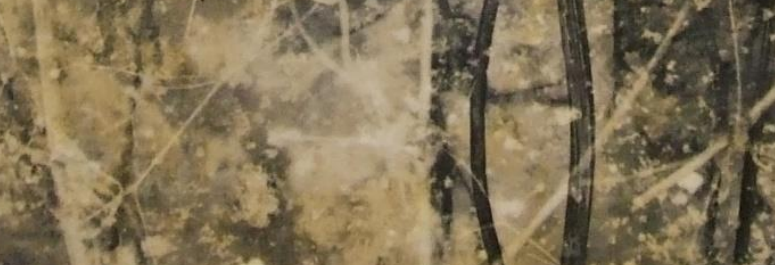

X

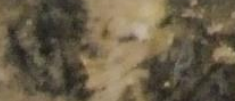

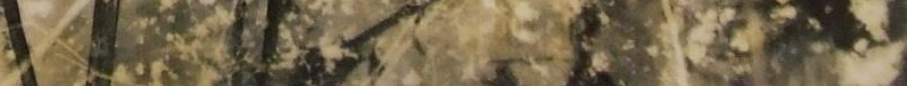

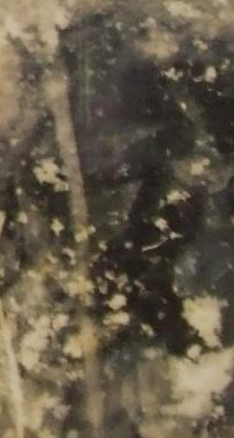

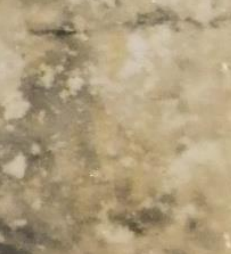

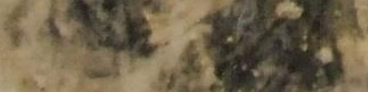

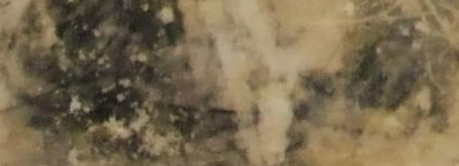
1)
s.
$0, x^{2}+\sin ^{2}$ atory

$x \rightarrow \frac{1}{4}, 401$ 
Anna Kola, from the series Plants, mixed media (toned photograph, resin), 100x70 cm, 2007 
Part Three: Spectral Media 



\title{
The Gaze of the Spectral Setting in the 1968 BBC Adaptation of M. R. James's "Oh, Whistle, and I'll Come to You, My Lad"
}

\author{
Anne Keithline \\ Independent scholar, USA \\ annekeithline@gmail.com
}

\author{
Jacek Mydla \\ University of Silesia in Katowice \\ jacek.mydla@us.edu.pl
}

Received 19 March 2017; accepted 26 October 2017.

\begin{abstract}
This article is a study devoted to the BBC adaptation of a ghost story by Montague Rhodes James, "Oh, Whistle and I'll Come to You, My Lad." The ideas of the spectral gaze and sympathetic spectreship are used to submit that in the film the setting itself is the spectre, with which/whom the viewer is invited to identify. This rearrangement - in comparison with the situation in the original story - casts the spectral setting both in the role of the haunting presence and the victim of an otherworldly (human) intrusion. A detailed analysis of the use of the camera supports the argument.
\end{abstract}

Keywords: ghost story genre; film adaptation; haunting; gaze; identification.

\section{Introduction: The Gaze, the Haunting House, and Sympathetic Spectreship}

"The gaze" is a popular term in contemporary film theory. "Male gaze" has been used to describe the position of superiority of a perceiving subject, gendered male, over a perceived object, gendered female. In a typical film-viewing situation, this perceptive empowerment - as we might call it - is a source of aberrant, sadistic pleasure; the camera is the instrument used to provide it. In a summary of this theory as propounded by Christian Metz, Sue Thornham explains that "the all-powerful gaze of the camera" "offers its viewer a powerful and eroticised gaze." "Cinema's voyeuristic pleasures," she goes on to say, "are therefore both more sadistic and more fetishized" (1999, p. 54). The concept of the gaze has been adapted both inside and outside of film theory, for example in gender studies, postcolonial studies, and critical race theory. What these diverse interpretations have in common is the idea of the dominance of the perceiver over the perceived, as when Laura Mulvey 
describes the female figure represented by the camera as placed as or reduced to an "exhibitionist": "women are simultaneously looked at and displayed, with their appearance coded for strong visual and erotic impact so that they can be said to connote to-be-lookedat-ness" (Mulvey, 1999, pp. 62-63; italics in the original). The same is true in the case of the spectral gaze, a term which has begun to gain currency in film studies and within the emerging interdisciplinary fields of hauntology and spectrality studies: it dominates the onscreen victims of haunting, showing them at their most vulnerable, and enables the viewer to participate in all the voyeurism and sadism associated with cinematic gazing.

The spectral gaze offers especially interesting features within the type of ghost film whose concern can be described as the "haunting house," where the film's "ghost" is in fact an entire spectral terrain infused with an omnipresent supernatural presence; hence the term haunting, rather than haunted, house. ${ }^{1}$ Haunting houses on film may be created in various ways, the most common being simply to demonstrate through the plot that the setting of the film is itself a supernatural presence. For example, a setting may seem to actively work to discourage the human protagonists from remaining there, as in The Amityville Horror, or simply to terrorize and kill them, as in The Blair Witch Project. More interesting for a discussion around the spectral gaze, however, are films in which the spectral setting is established primarily by the action of the camera. In such films, point-of-view shots and other camera techniques are used to assign a spectral consciousness, with its own subjective gaze, to the terrain itself. Walls, trees, gravestones, furniture, and so on seem to watch the protagonist, and the viewer experiences much, if not all, of the film through the eyes of this spectral setting. Such is the case in the BBC's 1968 adaptation of Montague Rhodes James's “Oh, Whistle and I'll Come to You, My Lad," where the moody gaze of the spectral setting colours the viewer's experience of the narrative every bit as strongly as the chatty, ironical narrator of James's original story. ${ }^{2}$

M. R. James, a recognised classic of the ghostly tale, was sensitive to how decisions on visual information and spectator identification impact the reader's experience of a literary haunting. In texts that accompany his stories, he enumerates aesthetic criteria for the

\footnotetext{
${ }^{1}$ The spectral setting of a haunting house film does not, of course, have to be an actual house, although many, like Obayashi's 1977 House and Rosenberg's The Amityville Horror, of the same year, are; Kubrick's 1980 The Shining and Myrick and Sanchez's 1999 The Blair Witch Project both feature spectral settings out-of-doors. The haunting house film is distinct (though indeed, sometimes not so distinct) from the more familiar haunted house film, where the "ghost" is a discrete supernatural entity appearing/trespassing in the everyday world of the "natural," as in the BBC's 1980 production of Hamlet.

${ }^{2}$ The strategy of using the camera to establish the spectrality of the setting may be used to various degrees within a film. For example, some haunting house films, such as Raimi's 1981 The Evil Dead, use camerawork at times establishing and reinforcing the spectral gaze of the setting, and at other times establishing other perspectives, such as those of the characters, or an impersonal third-person. Some, like Blair Witch, prioritize the characters' point of view and exclude the gaze of the spectral setting altogether. The BBC's adaptation of "Whistle" represents the far end of the spectrum when it comes to camerawork's role in the creation of the spectral setting, with nearly every shot reinforcing its first-person perspective.
} 
haunted tale: visual reticence in the portrayal of the ghost; a gradual introduction of the spectre into the narrative, until the growing strength of its presence culminates in a "final flash or stab of horror" (James, 2009, p. 351); the necessity for sympathetic identification by the reader with the victim of the haunting; and the intention to make the reader feel "pleasantly uncomfortable," as though, "If I'm not very careful, something of this kind may happen to me" (James, 2009, pp. 337-338). ${ }^{3}$ His short story "Oh Whistle, and I'll Come to You, My Lad" (1904) fully embodies these criteria. Visual representations of the ghost gain suggestive power by leaving much to the imagination, and the ghost is introduced in such a manner as to gradually diminish the possibility of it being "explained away." The human victim —or, as James terms him, the "patient" of the haunting (2009, p. 340) - is young, bookish, highly skeptical of the supernatural, and a bit too curious for his own good: a character type that would have been easy to sympathize with for James's original audiences of Cambridge students. The sense of "pleasant uneasiness" grows, and the eventual crescendo, when the protagonist finally comes "face to face" with the ghost, is used to great effect. James's artistic success in this story may be the reason why "Oh, Whistle" remains one of his most popular, and why it would inspire the best-known film adaptation of his work.

The 1968 BBC adaptation is a remarkable study. Highly faithful to the original James in terms of the plot, the methodical application of conventional camera techniques such as the obstructed shot, the wide angle shot, the tracking shot, the pan, and the point-of-view shot are used to create a visual commentary on the narrative wholly absent from the original text. Therefore, in our analysis of the film, we first offer a close-reading of this adaptation, outlining how the action of the camera makes the viewer a participant in the gaze of the spectral setting. We argue that the use of the spectral gaze to associate the viewer with the spectral setting, a "sympathetic spectreship" of sorts, ${ }^{4}$ complicates James's original interpretations of the significance of ghosts and haunting, and problematizes the very concept of the gaze by subverting the privilege traditionally accorded to the gazer even while it emphasizes the voyeurism and sadism inherent in all forms of the gaze. Sympathetic spectreship places the viewer in an uneasy position, the position of one who is both a participant in the spectre's plight (which in this case has to do with the intrusion of

\footnotetext{
${ }^{3}$ For an illustration of the relevance of James's criteria for very recent inflections of supernatural horror in film see J. Mydla, “Old-Type Hauntings by New Ghosts? Word and Image in the 'Cybernatural Horror' Unfriended”' (2017).

${ }^{4}$ We have coined this term as an allusion to the concept of "sympathetic spectatorship," itself the subject of much discussion in studies of Gothic literature and film. Sympathetic spectatorship has been nicely summarized by Simon Hay as a reader's "sympathetic engagement with suffering" through a text. Says Hay, "sympathy ... begins with imaginative identification: we imagine ourselves into the identity of a wronged or wounded person, and respond as if we were in their shoes" (Hay, 2011, p. 34). In ghost fiction, the identification traditionally takes place between the reader/viewer of the ghost literature/film and the human "patient" (as James would put it) of the haunting. However, in cases where the spectre itself is the "patient," our term "sympathetic spectreship" specifies identification between reader/viewer and spectre. For a recent discussion on "sympathetic spectatorship," see J. Mydla, "Joanna Baillie's Dramatic Experiments with Strong Passions in the Light of the Idea of Sympathetic Spectatorship" (2016).
} 
James's protagonist into the spectral setting) and the perpetrator of the haunting at the centre of the ghost story. In other words, as a participant in the first-person gaze of the spectral setting, the viewer finds herself both the subject and the object of haunting.

\section{The Camera in the Service of the Spectral Gaze}

The camerawork in "Whistle" is responsible in great part for establishing the spectral gaze and its intimate relationship to the viewer. Other filmic elements, especially sound, also contribute; however, this paper focuses on the visual contributions of the camera, first because they are sufficient to prove the integral role of the spectral gaze in the overall scheme of the adaptations, and second, because James's critical concerns when it comes to his own ghostly creations are primarily visual. This section will discuss how common camera techniques, like the obstructed shot, the wide shot, the tracking shot, the pan, and the point-of-view shot work together to create the quality of "peering," overlooking, and spying on the protagonist; these haunting qualities comprise the gaze of the spectral setting, in which the viewer participates. It goes without saying that, taken each by itself, or used only once or twice, these techniques would not be enough to create the gaze of the spectral setting. After all, the techniques are used in nearly all films and, in the vast majority of them, they are used for purposes other than to create the gaze of a spectral setting. However, they are used so methodically and so frequently in this adaptation that the result is the creation of the spectral setting and its gaze.

One of the most distinctive motifs in "Whistle" is the obstructed shot, which creates the sense of a spectral consciousness, furtively watching the protagonist, from the very first moments. The camera consistently views Parkin from behind something else ${ }^{5}$ : early on, we see him entering a car, dwarfed first by the headlight, then by the side panel, and then by the driver, steering wheel, and front seat (2:26-2:50). To name a few more obstructions out of many: as the film progresses we see Parkin from behind a bed (6:42-7:00), the back of a dressing-table mirror (8:26), dining table settings (12:31), gravestones overgrown with brambles (15:06-15:24), a mass of bones and roots protruding from an eroded grave about to slide down a cliff (16:25-16:45), bedposts (19:58-20:35), grasses (26:15-26:48), and wooden shore-constructions known as groynes (30:47-30:58). Some of these obstructions, like the mirror, the table settings, the bedposts, the grasses, and the groynes, become motifs that occur three or more times throughout the course of the film. The repetition of obstructed shots contributes to a growing impression that whatever is behind the gaze represented by the camera wishes not to be seen, an impression that is reinforced by the fact that the camera is frequently moving in these shots in order to remain hidden. For example, a shot of Parkin at his dressing table, partially obscured by the back of the mirror, becomes even more obscured when the camera tracks left to include not more of Parkin, but of the back of the mirror (8:25), as though its gaze were that of a conscious entity making doubly

\footnotetext{
${ }^{5}$ James's Parkins, the protagonist and the "patient" of the haunting in the original.
} 
sure that it will not be seen by the protagonist. ${ }^{6}$ Besides repetition and movement, the variety of angles and locations for obstructed shots creates a sense of spectral omniscience: a sense of a gaze belonging to the walls, to the dunes, to the beach - in short, to a spectral setting, rather than a discrete spectre or other source. This setting does not have to "follow after" Parkin, because it is already there, wherever he is. At a critical moment when, in a dream too real to be just a dream, Parkin hops over a groyne to escape a menacing spectral pursuer, the pattern has already been established: there can be no hiding place for Parkin on the other side of anything, because the camera/spectre/viewer is already there $(31: 21)$.
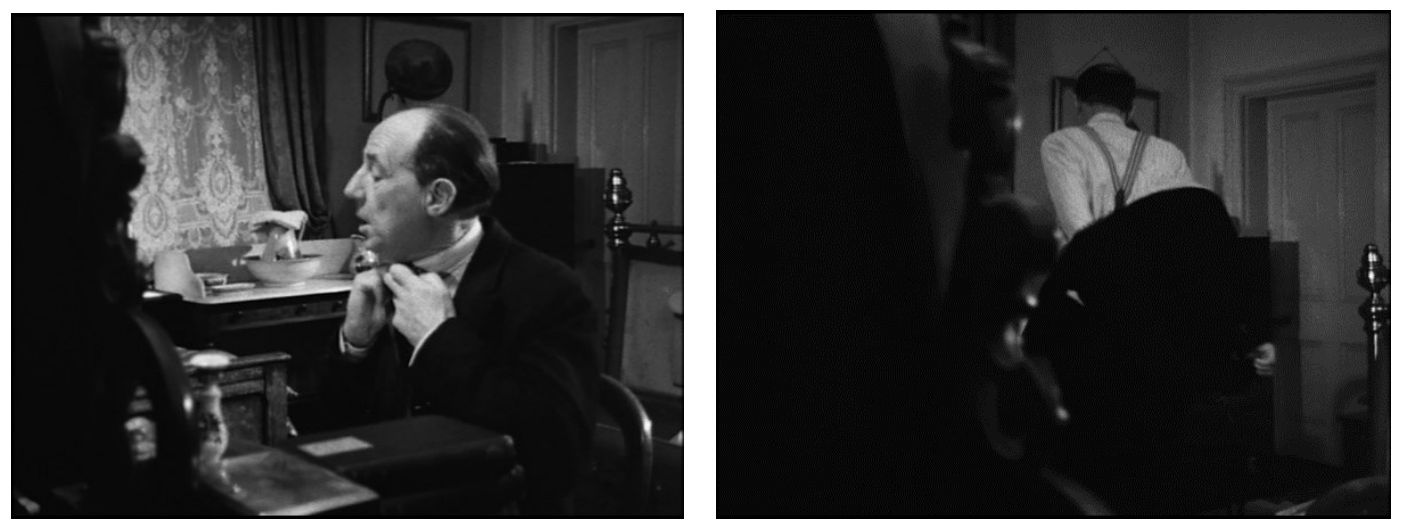

Figure 1. Obstructed shot becoming more obstructed from 8:21 to 8:25.

Another type of shot used to create the gazing spectral setting in "Whistle" is the very wide shot. In such a shot, Parkin is out in the open, whether on the dunes or on the beach, his far-away form dwarfed by the landscape. Very wide shots are either combined with obstruction (13:35-14:00) or not (14:00-14:19), but the result is the same: the feeling that Parkin is being stalked by something that is not human. That the gaze is coming from the land itself is established when very wide shots start and end without Parkin as the main focus, communicating that the gaze predates his presence and will outlast it. For example, at 24:48 we cut to a shot of an old stone bridge. Parkin is not in the shot. When he enters,

\footnotetext{
${ }^{6}$ This impression of furtiveness, caution, and stalking establishes the "personality" of a first-person presence and eliminates the possibility of third-person distance in these shots. Moreover, the first-person presence established cannot be a human, for two reasons: one, it would simply be impossible for a human to get into many of these positions; and two, we are at times shown in one shot the very area from which the subjective spectral gaze had just been emanating, empty of other sources of perspective besides that of the spectral setting. For example, the mirror-back shot of Parkin at his dressing table shows us the same part of his room that had just been "gazing" at him a moment before he sat down (7:24-8:09), empty of any possible spectator besides the spectral setting that has already been/is being established by the camera. In fact, what the mirror-back shot shows is that the origin of the gaze from 7:24-8:09 is the very bed whose sheets will later terrorize Parkin; many shots of Parkin in his room originate here.
} 
framed by the arch of the bridge, his form is already far enough away to be somewhat indistinct; he proceeds to walk in the opposite direction from the camera until he shrinks almost to invisibility. The shot lingers for almost an entire minute, ceasing at 25:42, far past the point of interest in terms of wondering what Parkin will $d o$; the interest exists in the sense of his obliviousness to this watching presence. A similarly lingering very wide shot is used in the context of the shore: we cut to the vast beach, empty of human presence until Parkin's foot comes down in front of the camera. He proceeds to walk away from the camera until he is dwarfed by the sky and sand (13:16-13:38). The long duration of the shot and the simplicity of Parkin's movement again place the interest not on him and what he will do, but on the tension created by the gaze of the spectral presence itself.

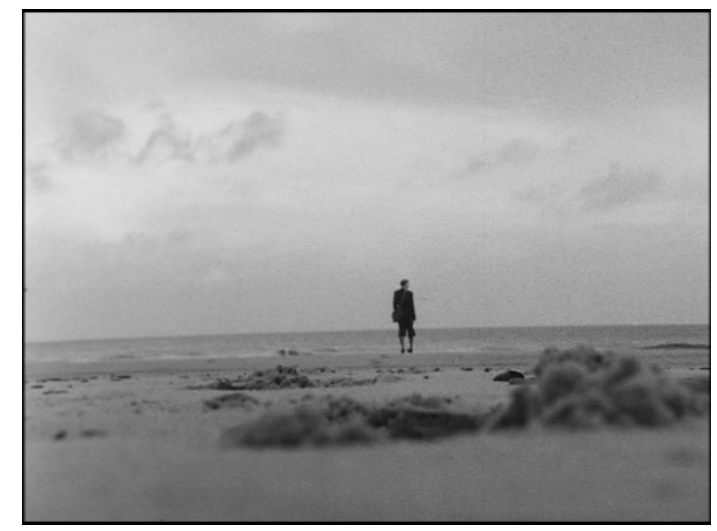

Figure 2. A very wide shot at 13:31.

Both the obstructed shot and the very wide shot are frequently combined with movement in the form of tracking shots and pans, which create the impression of an eye following a subject, and sometimes even of stepping to one side to avoid attention or to get a better view. Indeed, tracking shots and pans, as the primary types of camera movement in "Whistle," are important contributors to the overall "personality" of the spectral environment, not only because of what they are-short (only a couple of inches or feet at a time, as at $2: 28-2: 32$,) and medium-speed (about the same speed as a person would turn her head to follow the progress of an interesting object, as at 16:00-16:10) — but because of what they are not. Neither, for example, is a high-speed steadicam seeking the protagonist with the avidity of a demon, as in The Evil Dead. In "Whistle," tracking shots and pans are deliberate and cautious, with an ongoing curiosity implied through repetition. When paired with the obstructed shot, the track or pan lends the sense of a presence secretly watching from close range, as in the mirror-back shot. When paired with the wide shot, distance supplies the shelter that at close range is supplied by obstruction, and the sense of watching gains in boldness, as at 13:35-14:00. 
Most important of all in establishing the spectral gaze of the setting is the point-of-view shot-because, when the obstructed shot, wide shot, the tracking shot, and the pan are combined and deployed in so methodical a fashion, the end result is that they all become point-of-view shots. So strong is the resulting sense of subjectivity that even shots which, taken outside the context of the overall cinematic scheme, would never seem like pointof-view shots on their own, are given that cast by the sheer weight of the precedent set by previous, and reinforced by subsequent, shots (for example, when Parkin hops over the groyne in his dream). ${ }^{7}$ This is the essence of the gaze of the spectral environment: a presence that is more than the sum of its parts; for the pattern, once established, takes on a life of its own in the mind, and the gaze, of the viewer. ${ }^{8}$

\section{The Adaptation in View of the Gaze and of M.R. James's Aesthetic of Literary Ghostliness}

We have seen that, due to the actions of the camera, the ghost in "Whistle" is no longer, as in the original, a solitary spectre, foreign to the human world, but is, in fact, the very setting of the film itself. We have also seen that the viewer is strongly identified with this spectral setting, spends the duration of the film witnessing the protagonist from the spectre's point of view, and also, through the mechanism of the gaze, participates in the spectre's terrorizing of the protagonist. Inquiring how these fundamental changes impact our understanding of the film as an adaptation of James allows us to examine some conceptual ramifications of the differences in the respective aesthetics. We will also examine how assigning the gaze to the spectral environment calls viewer privilege into question, even as it heightens the sadism and voyeurism characteristic of all forms of the gaze.

Let us first look at a criterion of James's directly touching upon the issue of spectator identification. According to James, his ghost stories must make his reader identify with the "patient" of the haunting, by which he means the human protagonist (James, 2009, pp. 339-340).

\footnotetext{
7 "Still" shots, in particular, add to the sense of subjectivity by never being completely still. The camera always shakes slightly, implying the motion of a first-person gazer. The shot from 20:10-20:25 is one "still" shot out of dozens with this slight shake.

${ }^{8}$ Another reason the shots discussed above are so effective for establishing the sense of furtive watching could be that they draw from pre-established patterns in camerawork associated with surveillance and paparazzi, two themes that were popular in New Wave films of the time like Peeping Tom (Powell, 1960), La Dolce Vita (Fellini, 1960), and Blowup (Antonioni, 1966), where they often really are used as point-of-view shots - the point of view of an onscreen character looking at the scene through the lens of a camera. The BBC's "Whistle," (along with other BBC adaptation of the stories, e.g. "A Warning to the Curious") capitalizes effectively on these associations to create the impression of an omnipresent spectral gaze in which the viewer takes part. It may be interesting to look for connections between the rise of haunting house films, the use of camera techniques invoking surveillance, and public anxieties around increasing surveillance in public and private life during the nineteen-sixties, seventies, and eighties. In the years after "Whistle," films like Coppola's The Conversation (1974) and Radford's Nineteen Eighty-Four (1984) would feature settings which, even if they cannot truly be called spectral, are endowed with an omnipresent awareness similar enough to that in "Whistle" (and other haunting house films) for the parallel to warrant further attention.
} 
It is through such identification that the haunting gains its power to unnerve. This criterion is borne out fully in the text of the original, where the creation of the feeling of unease depends on reader identification with the overly-curious and imprudently skeptical Parkins. In the adaptation, however, the action of the camera identifies the viewer with the spectral setting, rather than with Parkin. Established as an omnipresence whose personality and point of view dominate the film and the viewer's experience of the plot, the setting-asspectre cannot really be said to be "otherworldly." Instead, it is the protagonist who enters from outside the boundaries of the film's "world" and transgresses the norms of that world. Moreover, the viewer's participation in the point of view of the spectral setting allows her to sympathetically experience the spectral consciousness undergoing that transgression, which may be described as the appropriation of a part of the spectral setting, the whistle, by the otherworldly intruder, the human. In this sense, James's dictate that the viewer identify with the "patient" of the haunting is still carried out by the adaptation, but with a key difference: the patient is no longer the human protagonist, but the spectral setting itself.

Complicated by this shift of emphasis to the spectral experience is James's concept of reticence, or economy of vision. The original "Whistle" follows James's dictate that "[r]eticence may be an elderly doctrine to preach, yet from the artistic point of view I am sure it is a sound one. Reticence conduces to effect, blatancy ruins it ..." (James, 2009, p. 347). On the surface, it may seem like the adaptation is faithful to James on the point of reticence. After all, we cannot get a definitive sense of what the spectre looks like. But there is a key difference: in the adaptation, the spectre is $u s$. This is an altogether different form of uneasiness than that created in the original, where the unknowable is still external. The viewer of the adaptation, through identification with the spectral gaze, has been made uncanny. The viewer might even be said to undergo a type of violence by this symbolic regression to a state of development prior to Lacan's mirror stage, although to elaborate on this point would be beyond the scope of the current paper. ${ }^{9}$ Finally, the sense of spectre/self created by the camera's movement is enhanced-made, ironically, more "real," more complete - by the sense of incompleteness, of unknowability, of unseeability. Thus, the anxiety which in James is created by a threat from an external menace, incompletely seen and known, is updated to the more modern horror of an existential threat coming from inside, and relating to the unknowability, or even the unreality, of the self.

Similarly updated is James's stipulation that ghosts be introduced gradually into a story. In James, ghosts often initially appear through phenomena that are easy to explain away: the ghost in the original "Whistle" is first manifested through ambiguous elements like dreams, a shadowy figure on a beach, and signs of disturbance in a bed that was not supposed to have been slept in. Gradually, the evidence mounts, until the protagonist, in the

\footnotetext{
${ }^{9}$ There seems to be a connection between the Lacanian mirror stage and the gaze. Anneke Smelik writes: "Mulvey explains narcissistic visual pleasure with Lacan's concepts of ego formation and the mirror stage. There is an analogy between the way in which the child derives pleasure from the identification with a perfect mirror image and forms its ego ideal on the basis of this idealized image, and the way in which the film spectator derives narcissistic pleasure from identifying with the perfected image of a human figure on the screen" (Smelik, 1998, p. 10; for a debate see Copjec, 1994, p. 30 ff).
} 
Jamesian "final flash or stab of horror," experiences something that he cannot explain away (though the possibility, however slight, is left to the reader.) In the adaptation, this scheme is done away with, as the spectral setting is introduced from the beginning through the methodical application of the camera techniques discussed above. However, the sense of the gradualness of the introduction of the ghost remains, because the viewer detects only gradually-if, indeed, at all — the presence of the spectral gaze in which she takes part. This is due in part to the fact that camerawork is part of what phenomenologists like Husserl would call "hyletic" data: information of the kind viewers look through in order to perceive a depicted object (Casebier, 1991, p. 13). ${ }^{10}$ However, once the viewer has had the "flash" of insight and noticed the activity of the camera as it creates the gaze of the spectral setting, it becomes difficult or even impossible to "unsee" it-perhaps an appropriate outcome for one who has noticed the presence of a spectre.

Assigning the spectral gaze to the spectral setting results in the rise of two characteristics that distinguish the gaze in "Whistle" from other manifestations of the gaze. First, the voyeurism and sadism characteristic of all forms of the gaze (Male, Imperial, Spectral, etc.) are heightened in "Whistle" when camerawork puts the viewer into the first-person position of the spectral setting. Take, for example, the impact of this identification on James's "final flash or stab of horror" (the moment when his protagonist and reader encounter the ghost "face to face"). The flash of horror is still there in the adaptation, but with a key difference: when the viewer and the ghost share the same point of view, the horror that we witness in Parkin, we also seem to cause. For contrast, consider The Blair Witch Project, which falls on the opposite side of the spectrum of spectre/protagonist identification in that the substance of the film is made up entirely of shots from a camera held by the protagonists, creating a sense of experiencing the protagonists' horror through their eyes. Thus, though part of the pleasure of the film may indeed be a sadistic satisfaction in our voyeuristic power over the protagonists in their vulnerable, horrified state, we are not involved with creating that horror in the same way we are with "Whistle," where the camerawork forces us to experience the protagonist's horror almost solely from the spectre's perspective. ${ }^{11}$ The viewer not only experiences Parkin's horror vicariously, simply by seeing it, as in Blair Witch and other horror films; in "Whistle," the viewer is made a co-author of that horror through her participation in the first-person gaze of the spectre. The sadistic

\footnotetext{
${ }^{10}$ Other examples of hyletic data are colour, palette, editing techniques, soundtrack, and so on.

${ }^{11}$ The forty-two-minute film contains only two shots (eight seconds total) that can confidently be said to be from Parkin's point of view (6:36-6:41 and 34:09-34:12), and it also has several shots which at first seem like they could be from Parkin's point of view, but are immediately shown not to be when he enters them. For example, one shot that at first could be construed as a Parkin-POV shot has Parkin at his desk making a rubbing of the inscription on the whistle. But this shot is shown to be an over-the-shoulder close-up when the side of Parkin's face enters at the upper-right (18:46). Moreover, throughout the shot, the camera shakes and zooms slowly closer, implying another instance of the curiosity of the spectral setting. A second example is at the climactic moment of haunting, when the bed sheets rise out of the bed. One slightly shaky "still" shot from 40:03-40:05 seems to imply Parkin's point of view. But a return to the same shot at 40:08 disproves the implication when Parkin runs into the frame. This pattern of implication/refutation is repeated in different settings throughout the film.
} 
and voyeuristic qualities of the spectral gaze are thereby enhanced in "Whistle" and, we would hypothesize, in other horror films where camerawork marries the viewer's participation in the spectral gaze to a first-person experience of the spectral setting.
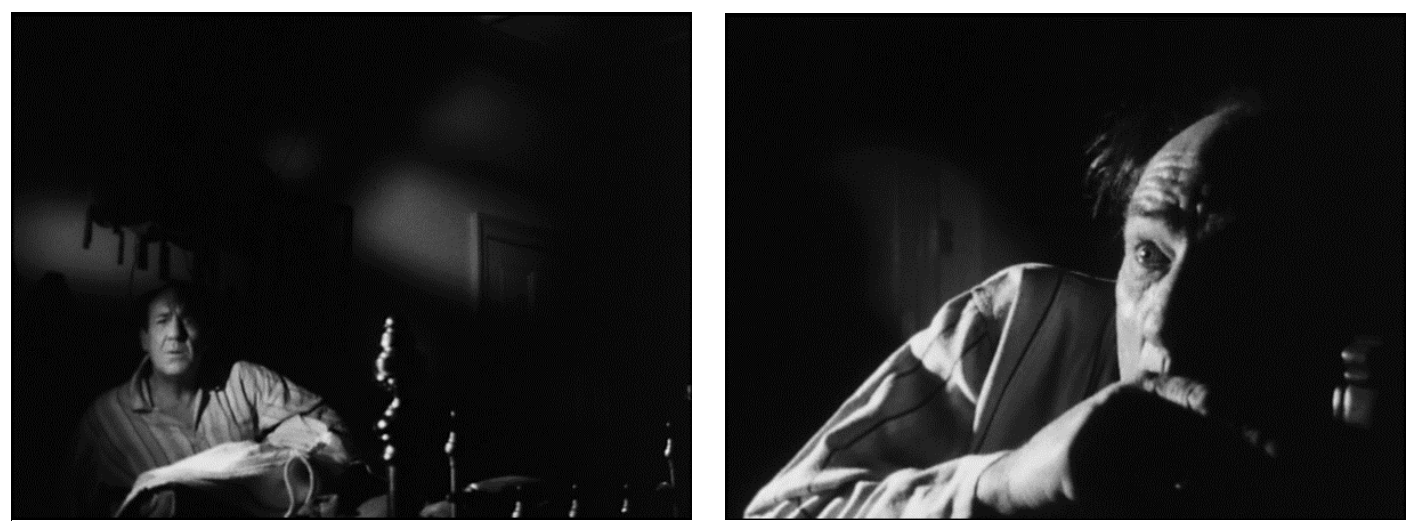

Figure 3. Horror from the spectral point-of-view at 40:03 (POV of the haunted bed) and 40:26 (mirrorback shot).

Further complicating the relationship of the spectral gaze in "Whistle" to other types of gazes is the question of how the power privilege of the viewer-gazer is affected in situations where 1) the viewer is identified with the first-person gaze of the spectral setting, and 2) the spectral setting is intruded upon by a human protagonist during the course of the film (the reversal of the "patient" relationship discussed above). The viewer of "Whistle" not only experiences the elements of haunting/gazing that embody the perceptive empowerment of all forms of the gaze; she is also, throughout the film, exposed to the experience of being a spectral setting subjected to the intrusion of the protagonist. In such circumstances the first-person gaze of the spectre is characterized not only by the power of the gaze over its subject (the human protagonist) but by the violation of that power through the protagonist's manipulation of the gazing spectral setting and, by extension, the viewer. Thus, the privilege traditionally accorded to the gazer ("I can subject you to something, but you can't subject me to anything") is called into question.

\section{Conclusion: A More Modern Horror}

As mentioned above, James maintained that the goal in his stories was to make the reader feel "pleasantly uncomfortable," a state of mind stemming from the idea that "something of this kind may happen to me" (James, 2009, p. 338). The sense of unease is still present in the adaptation, but it is decidedly less pleasant. For one thing, James's chummy and sarcastic narrator has been replaced by the moody gaze of the spectral environment. For another, the question, "what if such a thing should happen to me?" takes on a different 
character when the "me" in question is no longer the human "patient" of a ghostly haunting, but the ghostly victim of a human intrusion and the appropriation of ancient artefacts. The basic question that spooks the reader of the original, "What if I should be visited by a ghost?" becomes, in the adaptation, "What if I should be a ghost?" And further: "What if I should someday find myself in the position of this spectral environment-invisible, vulnerable, subject to invasion by others, and always unseeable/unknowable to myself?"; "What if I should be made to suffer the trespassing of a foreign presence into my territory, and become subject to the appropriation, and perhaps desecration, of my possessions?"; "What if I should become an agent of fear and violence to others, though my motivation may seem justified?" And even, "What if one or more of these things are already happening?"12

These questions belong to the postwar, postcolonial, postmodern world, a world that James never knew. His ghosts emerge from the past, recalled into the present through the violation of artefacts connected with bygone days. The BBC's "Whistle" is an important moment in ghost-story telling for its stark illustration of the massive ideological and aesthetic transitions between the time of James and that of the BBC adaptation: in only a little over half a century, ghosts have gone from haunting us, to being us. The fear is no longer of what may return from the distant past; no ghost could ever equal the horrors, or, perhaps even more chilling, the contradictions of life in the present.

\section{References}

\section{Films (in a chronological order)}

Fellini, F. (Director). (1960). La Dolce Vita. Italy: Riama Film et al.

Powell, M. (Director). (1960). Peeping Tom. United Kingdom: Anglo-Amalgamated Film Distributors.

Antonioni, M. (Director). (1966). Blowup. United States: Metro-Goldwyn-Mayer.

Coppola, F. F. (Director). (1974). The Conversation. United States: Paramount Pictures.

Obayashi, N. (Director). (1977). House. Japan: Toho.

Rosenberg, S. (Director). (1979). The Amityville Horror. United States: American International Pictures.

Bennet, R. (Director). (1980). Hamlet, Prince of Denmark. United Kingdom: BBC.

Kubrick, S. (Director). (1980). The Shining. United States: Warner Bros.

Rami, S. (Director). (1981). The Evil Dead. United States: New Line Cinema.

Radford, M. (Director). (1984). Nineteen Eighty-Four. United Kingdom: 20th Century Fox.

\footnotetext{
${ }^{12}$ Similar modern anxieties of not realizing the fact of one's own spectrality would be made more explicit, even acted out, in The Sixth Sense (1999).
} 
Myrick, D., \& Sánchez, E. (Directors). (1999). The Blair Witch Project. United States: Artisan Entertainment.

Shyamalan, M. N. (Director). (1999). The Sixth Sense. United States: Buena Vista Pictures.

Miller, J. (Director). (1968). Whistle and I'll Come to You. United Kingdom: BBC. In Ghost Stories for Christmas 1968-2010. Expanded Six-Disc Collection (2013). United Kingdom: BBC \& British Film Institute.

Gabriadze, L. (Director). (2014-2015). Unfriended. United States: Universal Pictures.

\section{Literature}

Casebier, A. (1991). Film and phenomenology: Toward a realist theory of cinematic representation. Cambridge, UK: Cambridge University Press.

Copjec, J. (1994). Read my desire: Lacan against the historicists. Cambridge, MA: MIT Press.

Hay, S. (2011). A history of the modern British ghost story. New York, NY: Palgrave.

James, M. R. (2009). “Casting the Runes” and other ghost stories. Oxford, UK: Oxford University Press.

Mulvey, L. (1999). Visual pleasure and narrative cinema. In S. Thornham (Ed.), Feminist film theory: A reader. Edinburgh, UK: Edinburgh University Press.

Mydla, J. (2016). Joanna Baillie's dramatic experiments with strong passions in the light of the idea of sympathetic spectatorship. In T. Bruś \& M. Tereszewski (Eds.), Production of emotions: Perspectives and functions. Frankfurt am Main, Germany: Peter Lang.

Mydla, J. (2017). "Old-type hauntings by new ghosts? Word and image in the 'Cybernatural Horror' Unfriended." in esse: English studies in Albania. Journal of the Albanian Association for the Study of English (ASSE), 7, 64-82.

Smelik, A. (1998). And the mirror cracked: Feminist cinema and film theory. Basingstoke, UK: Macmillan.

Thornham, S. (Ed.). (1999). Feminist film theory: A reader. Edinburgh, UK: Edinburgh University Press. 


\title{
Hauntology, Performance and Remix: Paradise // Now?
}

\section{Edyta Lorek-Jezińska}

Nicolaus Copernicus University in Toruń lorek@umk.pl

Received 5 August 2017; accepted 30 October 2017.

\begin{abstract}
Drawing upon concepts of hauntology and spectrality and their applications in performance and media theory, the article investigates the relation between live performance, performative memory and technology in Komuna Warszawa's project Paradise Now? RE//MIX Living Theatre. Premiered in 2013 as the 31 st part of the remix sequence bringing together the past works of international experimental artists and theatres and present-day Polish performers and dancers, Paradise Now remix offers a critical and self-referential commentary on what is left after the demise of political theatre and the utopian dream of paradise. My main argument focuses on the technological processes by which Komuna Warszawa spectralizes both the memory of the Living Theatre's Paradise Now and its own performance through re-mediating, digitizing and remixing fragmentary images and scenes. Their ultimate effect is a melancholic sense of disappearance, impossibility and technologically produced vacuum.
\end{abstract}

Keywords: hauntology; performance; technology; remix; the Living Theatre; Komuna Warszawa. 
To be haunted by a ghost is to remember what one has never lived in the present, to remember what, in essence, has never had the form of presence. (Derrida, 2013, p. 38)

So in some kind of rhetorical legerdemain, we keep up the plot, the archival burial ground, saying all the while that the life or afterlife of texts is all their own, and not an effect of embalming processes in which we engage. (Wolfreys, 2002, p. xii)

\section{Introduction: Hauntology, Remix and the Living Theatre}

Perhaps as a result of the ubiquity of ghosts following the spectral turn in contemporary literary and cultural criticism and theory (Weinstock, 2013, pp. 62-63), haunting has become a powerful metaphor that can be used quite surprisingly to explain the modes of existence of both live performance and mediated and recorded image and action. Hauntology can be applied in theatre studies to conceptualize significant aspects of live performance. ${ }^{1}$ The argument that theatre is the medium that is particularly haunted and determined by its own spectrality has been put forward by some scholars, emphasizing the theatre's authenticity and immediacy as well as its problematic reproducibility. The theatre's evanescence and its concrete materiality make exact reproduction and effective archiving impossible. The primary application of hauntology in performance studies serves the description of the ephemeral nature of a theatrical event and its inherent irreproducibility. The concept of haunting is also used to expose the significance of performative memory, in which theatre events are stored. This aspect is further related to the questions of archiving and documenting performance. Theatre documentation as such can be understood in terms of spectralisation; in this context hauntology helps to embrace the peculiar relation between the live event and recorded image. In this field it overlaps with its ostensible opposite and another haunted phenomenon, the haunted media. ${ }^{2}$

All of the abovementioned conceptual aspects of performance and its mediated versions are actively deployed in the project by the Warsaw-based theatre company Komuna Warszawa entitled Paradise Now Re//Mix Living Theatre, which premiered in 2013. Paradise Now? Re//Mix is a part of the performance sequence realized between 2010 and 2014 together with other artists. The project consists of a series of stage productions, each devoted to a significant contributor to the history of performance and dance. Among the artists whose works were remixed in the sequence one can find Oskar Schlemmer, John Cage, Pina Bausch, Robert Wilson, Laurie Anderson, Jerzy Grotowski, Tadeusz Kantor, Dario Fo, Carolee Schneemann and many others. Beside the project commemorating the American

\footnotetext{
${ }^{1}$ In a sense the very concept of hauntology as developed by Jacques Derrida in Specters of Marx partly originates in drama and theatre, being inspired by Shakespeare's Hamlet. Acting has been conceptualized as haunting or being haunted by theatre critics and practitioners, such as Tadeusz Kantor or anthropologists seeing origins of theatre in shamanistic rituals and possession by spirits. See E. Lorek-Jezińska (2013, pp. 33-38). Carlson's idea of the haunted stage will be mentioned further in the article.

${ }^{2}$ Also in Specters of Marx Derrida comments on the spectralizing quality of the media as existing beyond the notion of ontology and thus demanding a new category — the one of hauntology (Derrida, 2006, p. 63).
} 
alterative and political theatre - the Living Theatre - founded by Judith Malina and Julian Beck in 1947 in New York, Komuna Warszawa was engaged in the remix performances for Kartagina by a legendary Polish theatre company Akademia Ruchu (2010) and in the project called Komuna Warszawa vs. Majakowski (2011) (Plata \& Sajewska, 2014, pp. 254-265).

According to the description on Komuna Warszawa's web pages, remix is a concept adapted from music, which can be defined as a work in which the fragments, or samples, of the original are present as quotations. Despite its derivative character, remix can also function as a new piece of art "engag[ing] with the original through its form or content, entering into dialogue with it, nostalgically recalling it or finding in it new meanings" (Komuna Warszawa, 2015b). The remix formula involves processes that can be described in terms of haunting and spectrality. Remix relies on the interaction between the past theatrical and artistic projects and the present time, filtered through memory and documentation. It can be conceptualized as a form of resurrection of the past or perhaps more adequately as haunting of the present by what is gone. By referring to the past artistic projects, RE//MIX emphasizes connection, continuity and influence, but also a desire to break with the impact of the past tradition by spectralizing and mediatizing the original. In doing so, the remix performance is positioned between the two impossible but compelling options: annulling the past by transforming it into digitalized images or remembering it, which, like remembering the dead, is "neurotic and obsessive . . . and feeds a sterile repetition" (Jameson, 2008, p. 58).

In his study of remix and remix culture Eduardo Navas distinguishes between four types of remix, three of which might be particularly useful in the contextualization of the project under consideration. The selective remix is based on adding or subtracting elements from the original but preserving its general "spectacular aura" while the reflexive remix challenges the original and claims its own autonomy, but contains recognizable elements from the source (at least recognizable as alien in the target form; Navas, 2012, p. 66). The third form of remix - the regenerative one - although not directly applicable here for its mostly digital communication contexts - can be associated with the processes of onstage digitalization going on in Komuna Warszawa's project. As Navas argues, "while [regenerative remix] liberates the forms that are cited from their original context, [it] opens itself up for ahistoricity, as well as misinterpretations. The principle of the regenerative remix is to subvert, not to recognize but to be of practical use" (2012, p. 73). The regenerative remix reaches the meta-level of "re-mediating the media" (James, 2016, p. 140) for its own sake. Komuna Warszawa's performance makes all of these types of remixes both active and problematic. Through its mechanized self-reflexivity the project asks questions of the choice and ethics of remixing both the original performance and the documentary material used in it. The remix project is deliberately torn between a drive of reconstruction and revival and critical de(con)struction of the original. The intention behind the remix concept, according to its curator Tomasz Plata, was to revive - to bring back to life - past artistic projects significant to a generation of artists on individual, non-representative or non-canonical basis and to integrate artists from different fields around them (Plata \& Sajewska, 2014, pp. 10-17). What Paradise Now? remix seems to be engaged in is 
demonstrating simultaneously the spectral inadequacy and irrelevance of the past political theatre and a kind of disaffected nostalgia for the political utopia and its innocent-and no longer possible - naivety.

The decision to remix the Living Theatre's performance with the use of video and computer technologies, sampling and imitating the fragments of the original recorded material, activates a number of conflicts and frictions. The Living Theatre, one of the longest running theatrical groups still active after Malina's death in 2015, has been dedicated to political and social activism, for a long time living as a commune, in which theatre was an integral element of life (Brook, 1990, pp. 69-70). Their basic aim was to change the world and restore the connections between people, following the utopian anti-war and anti-capitalist ideals. In their performances they often proclaimed the necessity of restoring the primacy of feeling and emotions over intellect and language, which are easy to manipulate and use as an alibi (Roose-Evans, 1973, pp. 157-159). They also emphasized the importance of corporeality, experience, personal and physical contact as well as presence (Pasquier, 1987, pp. 80-82). In the eyes of one of its creators, Julian Beck, Paradise Now was supposed to be "the act itself, primary and unrepeatable" and its form should "allow a release of spontaneous creative forces that could transform audiences and society" (Tylell, 1995, p. 226). It is both ironic and symbolic to transform this lively and "holy" (Brook, 1990, p. 70) theatre into a digitalized visual and auditory composition remixing the fragments of records into a different kind of intangibility characteristic of copies and replications.

By trying to confront the myth of the Living Theatre and its present afterlife, Komuna Warszawa's project explores the tensions between the immediate and the mediated, and the present and the past. Referring to the legacy of the Living Theatre and using multimedia resources, mixing film, photography and live acting, Paradise Now? remix investigates the (im)possibility of reproducing the archive of theatre history in live performance. The dominating principle that defines Komuna's performance is a sense of vanishing and emptiness created in a technologically induced vacuum, where the only meaningful and authentic element available is a filmed interview with Judith Malina, which seems inadequate as a memory and documentation of the Living Theatre's legacy. The interview was recorded by the company in 2013 in the Actors Home - two years before Malina's deathand is primarily concerned with the question of what paradise is nowadays (Gałązka, 2014, pp. 218-219). The performance exposes the processes of mediation at the cost of the mediated image and the memory of political theatre, creating the melancholic feeling of irrevocable loss of the past and the impossibility of the future.

In order to discuss the complexities of the remix process in Komuna Warszawa's performance, in the following part of the article I will refer to three major theoretical questions related to the concepts of haunting, performance and the media: the haunted stage and memory, the present time of performance and the concept of disappearance, and finally the haunted media and onstage digitalization. In Komuna Warszawa's performance all of these aspects are interrelated and run across both live performance and projected films and images. 


\section{The Haunted Stage and Memory_Paradise//}

The idea of the haunted stage used, among others as the title and the main concept of the 2003 book by Marvin Carlson, is primarily related to the concept of cultural memory that defines the experience of theatre. In the context of hauntological theory, a performance is compared to Derrida's revenant, which begins its existence by returning - reappearingpointing to the paradox of "beginning by coming back" (Derrida, 2006, p. 11). Each performance is constituted by repetition, by the return of the past productions and recognition of the familiar in the "audience's collective and individual memories of previous experience" (Carlson, 2003, p. 165). As a remix, the project by Komuna Warszawa relies on performative memory and recognition of the original performance. Yet this memory cannot be based on the actual experience and instead refers to its mediated versions, accounts, memoirs, documentaries, or scenarios. This indirect, mediated memory is subject to mythologization; the project's subversive and deconstructive strategies aim at comparison, juxtaposition and contrast between the nostalgic and mythologized image and what remains after the Living Theatre's performance today.

While Carlson uses the aspects of hauntology in the essentially intertextual meaning, which is highly significant in the remix formula, Komuna Warszawa's project seems to be engaged in the process of reducing all the performance components to the process of haunting in an almost literal sense. The fragments of the original performance-technologically transformed and reproduced-become detached from their original source and in a sense disembodied. It seems that the performance spectralizes itself by technological intervention and reproduction. The most representative example of this process is the complex act of spectralizing the live performance enacted on the stage. Recreating a fragment of the original production by the Living Theatre, the actors of Komuna Warszawa try to arrange the letters of the word paradise (in Polish) formed by their bodies. The live action is being filmed by several cameras, edited by several computers and then projected on the semi-transparent screen separating the performers from the audience. The meticulous technological reproduction of the original scene is devoid of the political engagement of the original. It exposes the inadequacy of the past form of political theatre in the context of the contemporary world. Similarly, the fragments of the original text are further divided, sometimes syllabified, superimposed on each other, repeated automatically without emotional engagement. By technological transformation, live action, live voice and the original texts and stage images are artificially reproduced while the aspects of performative memory based on experience are drastically reduced. The choreographic arrangements recreated on the basis of the original are separated from the audience by the screen, which makes any direct contact between performers and the audience impossible. This is a symbolic and spectacular negation of the proximity, participation and collective experience of the Living Theatre's original performance.

The culminating point of the production is a short film projected on the back screen presenting an actor of Komuna Warszawa who describes an act performed by the Living Theatre. This act involved diving from the stage or platform and falling into the arms of 
other performers and spectators. The two seconds of flight metaphorically present the utopia of paradise, which is so brief that it is almost non-existent. In the original performance the flying scene, devised by Ann Halprin (Innes, 1984, p. 250) and inspired by the Shamanistic ritual, comes to signify, as Innes argues, liberation and transcendence (Innes, 1993, pp. 187-188). The very act is built on trust, connection and interaction with other people. In the chanted words: "BREATHE... BREATHE... BREATHE... FLY" (Innes, 1984, p. 250), the emphasis is put on the moment of flying despite the fact that the act also involves the stage of falling down. In the performance by Komuna Warszawa the film presents a repeated sequence of the actor's body flying in the air, prolonging the moment of the flight endlessly. The actor describes the scene from the original performance in mythical unrealistic terms, referring to it as "rising into the air." Yet Komuna Warszawa's flying scene ends in the fall, as the actor repeats the sequence: "I breathe, I fly, I imagine, I see, I fly, I breathe, I see the paradise, I fall” (Luksza, 2014, p. 217; my translation) although the screen is blacked out before the fall actually happens. This artificially/miraculously generated simulacrum of utopia can be reproduced in a limitless repetition that only exposes the extent to which it can never become reality. Komuna Warszawa's performance - and the flying scene in particular - makes us aware of how the original performance easily yields to mythologization. To the generation that had no direct possibility of experiencing the Living Theatre's performance, it becomes accessible only in fragmentary documentation further deconstructed and fractured through the filmic and digital technologies which replace memory. This generational aspect surfaces in the company's description of the project and the questions asked therein: "So where are we, the commune, in all this? What else [is there], besides nostalgia, the touch of the legend? What else can we remember other than the afterimage of naked bodies gently twisting across the stage and revolutionary slogans shouted at the audience?" (Gałązka, 2014, p. 219; my translation). The performance provocatively asks what is left of political theatre and simultaneously answers: "What is left out of political art is art," adding almost offhandedly that in this case also an old woman and the question of paradise (Luksza, 2014, p. 214). The effect of various technological and conceptual strategies used by Komuna Warszawa can be seen as a deliberate travesty of political theatre, its formalistic antithesis.

\section{The Present Time of Performance and Disappearance—//now?}

In the remix project technological transformation also involves experimentation with the temporal aspects of performance and its phenomenology. Performance is often defined by the present time and its existence in the eternal now, ${ }^{3}$ which Szondi describes as "an absolute succession of "presents"' (as cited in Keir, 2002, p. 106). Yet the succession of presents involves also a succession of disappearances, which was described by Garner as "dys-appearance" accompanying "the presence of appearances" in performance (Fortier, 2002, p. 44). In this sense performance possesses the attributes of the ghost who/which

\footnotetext{
${ }^{3}$ The question of the present time of performance was addressed by many scholars and critics, e.g. Thornton Wilder, Martin Esslin (referring to Goethe and Schiller), Elam Keir, Peter Szondi, among others.
} 
cannot be located in a precise moment and exists in the state of constant disappearance. Each moment in performance creates an opening, a sense of "being-there of an absent or departed one" (Derrida, 2006, p. 6). This hauntological sense of disappearance defines the ontological status of performance, discussed among others by Peggy Phelan. Phelan argues that performance cannot exist beyond its actual happening and because of that is constituted by both presence and disappearance: “[t]heatrical performance is always bound to the present. For this reason, theatre continually marks the perpetual disappearance of its own enactment" (1993, p. 118). Phelan further suggests that "[p]erformance cannot be saved, recorded, documented, or otherwise participate in the circulation of representations of representations: once it does it becomes something other than performance" (1993, p. 146). The belief in the liveness and immediacy of performance has been criticized, among others, by Philip Auslander, who argues that there is no ontological difference between live and mediated performance and the belief in "performance's disappearance into memory" can equally apply to mediated arts (2008, pp. 184-186). Auslander also discusses a stable pattern according to which a new technology usurps the place of and imitates the live form of art but later provides the model for imitation for live art. Following Walter Benjamin, Auslander observes that the new (the 1990s) kind of expectation of the audience - also in relation to live performance-was the television-generated proximity and intimacy $(2008$, p. 184), which is now replaced with the "affordances of the digital media," which, as Jenkins, Ford and Green argue, "provide a catalyst for reconceptualizing other aspects of culture, requiring the rethinking of social relations, the reimagining of cultural and political participation. ..” (Jenkins, Ford, \& Green, 2013, p. 3). Komuna Warszawa's remix illustrates both of these seemingly contradictory processes, of the spectral disappearance of performance and its transformation into the phantasms generated by the media which replace the presence and immediacy of theatre. In this sense the remix creators deliberately enact the act of disappearance as a form similar to Phelan's concept of active vanishing. ${ }^{4}$

The Paradise Now remix project is built around disappearances. It is based on the strategies of annulling the present time of performance through technological editing and replication. Visual and auditory technologies distance the performers from their own bodies and voices. Spectralizing the live performance is a deliberate strategy exposing the extent to which there is no present time to refer to. In this context the Living Theatre's Paradise Now is a thing of the past. There is no possibility of restoring, recreating or reviving the original authenticity of performance and its direct kinetic and tactile appeal, including the experience of presence with others in the spontaneous, ritualistic communitas (Turner, 1982, p. 48), which was part of the original performance. What is left is a sense of loss,

\footnotetext{
${ }^{4}$ The concept of disappearance is used by Phelan also as a deliberate and conscious strategy of creativity: "I am speaking here of an active vanishing, a deliberate and conscious refusal to take the payoff of visibility" (1993, p. 19). She describes this strategy by the notion of "the unmarked," which refers to what is immaterial and "shows itself through the negative" (Phelan, 1993, p. 19). As a strategy disappearance involves asking questions ofand recognizing — who or what is absent — who or what is not there.
} 
the missing memory which can be only mediated through film and documentation. The aspects of active vanishing in the remix project expose both the inadequacy of the past performance to address contemporary audiences and the inability or even unwillingness of Komuna Warszawa to return and restore the theatrical past. The large screen at the back of the playing area onto which the video interview with aged Judith Malina is projected performs a similar function - of manifesting the chasm between the memory of the Living Theatre, its radical performance, youthful energy and trust in people and its present aging and outdated reality. At the same time, paradoxically despite its mediated nature and editing, the image of Judith Malina appears to be the most authentic element of performance, which after Malina's death in $2015^{5}$ seems to go on living its own spectral existence. The experience of immediacy, proximity and authenticity — or more likely its substitute - is conveyed through a mediated documentary image, not the live performance.

The concept of the present time of a performance can also be discussed in the context of Derrida's commentary on the impossibility of what we call real time. First of all, Derrida argues that "there is never an absolutely real time," but what we call real time is in fact "an extremely reduced différance" (2013, p. 47). And secondly, the only context in which we refer to our living in real time, according to Derrida, is "access precisely to what we are not living: we are there where we are not, in real time, through images or through technical relation" (2013, p. 46). The project realized by Komuna Warszawa experiments with the notion of real time of performance by delayed image projection that separates the living bodies from their performative stage images, the result of which resembles the act of "expanding" the différance. It subversively locates the real time of performance in the spectral past, which it seems both to restore and negate through the simulated reproduction.

\section{Haunted Media and Onstage Digitalization}

Spectral conceptualizations have been productively employed in the discussion of the nature of mediated images and sounds and the article has referred to some of them already. In this section I will refer to two major aspects of the onstage use of video and digital technologies, which are active in Komuna Warszawa's remix. The first one, mostly based on Derrida's reflections, views spectrality of technologies and media as related to death and crisis of existence. The second one connects media spectrality to phantasms, which offer a possibility of presenting what does not yield to representation and which evoke a sense of loss but also offer a creative potential.

In an interview with Bernard Stiegler, Jacques Derrida comments on the spectrality of technology and the media which is based on the miraculous nature of reproduced images and which cannot be undermined or questioned by our knowledge of the processes of their production: "We are spectralized by the shot, captured or possessed by spectrality in advance" (Derrida, 2013, p. 39) before we actually reappear in our mediated image. At this

\footnotetext{
${ }^{5}$ The present analysis is based on the performance given in March 2015, prior to Judith Malina's death.
} 
moment we are already symbolically dead because "we know that, once it has been taken, captured, this image will be reproducible in our absence, because we know this already, we are already haunted by this future, which brings our death" (Derrida, 2013, p. 38). Derrida conceptualizes the participation in the recording, filming and then projection process as miraculous because at the moment of our experience of the mediated/mediating image, we do not activate or perhaps do not wish to use our technical knowledge:

Our disappearance is already here. We are already transfixed by a disappearance [une disparition] which promises and conceals in advance another magic "apparition," a ghostly "re-apparition" which is in truth properly miraculous, something to see, as admirable as it is incredible [incroyable], believable [croyable] only by the grace of an act of faith. Faith which is summoned by technics itself, by our relation of essential incompetence to technical operation. (2013, p. 38)

The technologies used in the remix project generate the effects of spectralization at least on two levels. The primary one refers to the documentary recording of the interview with Judith Malina - first prematurely spectralized by technological reproduction and thenafter her demise - belatedly materialized in a video projection ${ }^{6}$. A more self-referential level is activated in the scene of filming and projecting images of live performance on the screen, mentioned earlier. Because during the performance the technical team and equipment are part of the onstage activities, the technical process loses the "magical" quality of which Derrida was talking in an interview. In fact, the exposed technical procedures seem to guarantee the authenticity of the reproduced images: we see the original, witness the recording and editing process, watch the projection and verify the equivalence of the two. However, we are further invited to extend this equivalence to the original performance of the Living Theatre, which can only be done by an act of faith. At this point, the very process of digitalization and mediation becomes self-referential in the manner of the regenerative remix, mentioned at the beginning of this article. The object to which the projected image refers (the original performance) is ostensibly absent, already dead and additionally spectralized by the vacuum that its intentionally failed reproduction produces.

In his commentary on spectrality, Julian Wolfreys defines the spectral as "that which makes possible reproduction even as it also fragments and ruins the very possibility of reproduction's apparent guarantee to represent that which is no longer there fully" (2002, p. 2). What makes the whole spectralizing process possible in Komuna Warszawa's remix project is the prior disappearance and transformation of the original into the documentary image. In this perspective the performance by Komuna Warszawa tries to reconstruct and duplicate the documentary process of the production and reproduction of the original and

\footnotetext{
${ }^{6}$ In the scene of a partly improvised interview in Ghost Dance (1983), directed by Ken McMullen, Derrida talks of himself as spectralized by being filmed and recorded, speaking the voice of the other. It is both disturbing and deeply ironic that an actress who was acting in the scene with Derrida-Pascale Ogier-died a year after the premiere. Derrida describes the double level of spectrality in the experience of re-watching the film afterwards (2013, p. 40). A similar effect expanding the spectrality of the Paradise Now remix is generated in seeing the production after Judith Malina's death, increasing the ethical dubiousness of using the video featuring elderly Malina in the performance.
} 
its black and white archival copy. It seems that for that reason the whole stage behind the transparent screen with the exception of the film presenting Malina imitates the range of colours available in black and white photography.

Technology in Komuna Warszawa's project and particularly in the onstage digitalization scene-despite its self-referential and self-annulling qualities - offers perhaps a more effective attempt at embracing the concept of paradise as phantasmatic opening of the invisible than the ironic, humorous and self-consciously irreverent lectures on the concept and probability of paradise delivered by an actor in front of the transparent screen. The screen projections of the actors' figures in Komuna Warszawa's performance in a way resemble the spectral effects produced by a system of reflections in the Pepper's ghost illusion. The ghostly, generated by technological means, as Tom Gunning argues in his study of the ontology of mediated vision through the prism of pre-modern categories, "fascinates us as a complex of two fundamental fantasies": of the phantasmatic body and of untimely presence (2013, p. 232). The former undermines our ability to uphold the separation between the material and the incorporeal while the latter juxtaposes the untimeliness of haunting with the other forms of the return of the past, such as memory or history (Gunning, 2013, p. 232). If we take Komuna Warszawa's project to be primarily based on phantasm reconstruction/production it operates along the line of melancholic attempt at hallucinatory return of the lost object (Gunning, 2013, p. 236) - in this case both the belief in the concept of utopia and social paradise and the possibility of reactivating immediate political theatre in the no longer innocent times of scepticism, self-awareness and digital reproduction.

\section{Conclusion}

Paradise Now? RE//MIX endeavours to re-visualize - through replication and the use of modern technologies - what has disappeared in time only to increase the melancholic sense of the thing that is gone. In doing so the project demonstrates the spectral inadequacy and irrelevance of the past political theatre to the present reality. The technological transformation of the recorded videos and the live performance both fragments and deconstructs the political utopian message of the Living Theatre's original performance, while teasing at times with the possibilities of computer generated image reconstruction and imitation. The sense of disappearance that the performance evokes does not signify the possibility of disregarding the type of theatre or thought that seems to have no appeal any more. In fact, following Fredric Jameson, one could say that the performance makes us aware of the extent to which our present is not "as self sufficient as it claims to be" (2008, pp. 39-58).

The remix formula on which the whole project is based relies on comparison, confrontation and active memory of the original. However, it refers to the memory that cannot be activated without the help of documentation. Once memory is artificially reproduced, it shows how inaccessible it is in any direct performative experience. Yet the futility of the reconstructive process is counterbalanced by its creative possibility. In a way, the technological spectrality of Komuna Warszawa's performance also lends itself to the pre-modern 
logic of the phantasm, which, as Gunning argues, "gains a new valency" in "the proliferation of virtual images" (2013, p. 211). The phantasm that is technologically and conceptually created through the new media "mediates between presence and absence, possession and loss, reality and sign, opening up a realm not only of mourning and symbolic action but also of play and artistry" (Gunning, 2013, p. 236). Komuna Warszawa's performance transfers or perhaps restores the concept of paradise, concretized in social and political action in the Living Theatre's performance, into the technological sphere of the phantasmatic, more indefinite, accommodating and detached.

\section{References}

Auslander, P. (2008). Liveness: Performance in a mediatized culture. Abington, UK: Routledge.

Brook, P. (1990). The empty space. London, UK: Penguin Books.

Carlson, M. (2003). The haunted stage: The theatre as memory machine. Ann Arbor: University of Michigan Press.

Derrida, J. (2006). Specters of Marx: The state of the debt, the work of mourning and the new international. (P. Kamuf, Trans.). New York, NY: Routledge.

Derrida, J. \& Stiegler, B. (2013). Spectrographies. In M. del Pilar Blanco \& E. Peeren (Eds.), Spectralities reader: Ghosts and haunting in contemporary cultural theory (pp. 37-51). London, UK: Bloomsbury.

Fortier, M. (2002). Theory/theatre: An introduction. London, UK: Routledge.

Gałązka, A. (2014). Autodokumentacja: Raj teraz. In T. Plata \& D. Sajewska (Eds.), RE//MIX: Performans i dokumentacja (pp. 218-219). Warsaw, Poland: Wydawnictwo Krytyki Politycznej.

Gunning, T. (2013). To scan a ghost: The ontology of mediated vision. In M. del Pilar Blanco \& E. Peeren (Eds.), Spectralities reader: Ghosts and haunting in contemporary cultural theory (pp. 207-244). London, UK: Bloomsbury.

Innes, C. (1984). Holy theatre: Ritual and the avant-garde. Cambridge, UK: Cambridge University Press.

Innes, C. (1993). Avant-garde theatre: 1892-1992. London, UK: Routledge.

James, K. (2016). Mapping critical media literacy onto iterative remix practice. In P. Ruggiano Smith \& A.M. Lazar (Eds.), Reconceptualising literacy in the new age of multiculturalism and pluralism (pp. 125-150). Charlotte, NC: IAP.

Jameson, F. (2008). Marx's purloined letter. In M. Sprinker (Ed.), Ghostly demarcations: A symposium on Jacques Derrida's Specters of Marx (pp. 26-67). London, UK: Verso.

Jenkins, H., Ford, S., \& Green, J. (2013). Spreadable media: Creating value and meaning in a network culture. New York, NY: New York University Press.

Keir, E. (2002). The semiotics of theatre and drama. London, UK: Routledge. 
Komuna Warszawa. (2015a). Paradise Now? RE//MIX Living Theatre (Live performance). Torun, Poland: Klamra Theatre Festival.

Komuna Warszawa. (2015b). RE// MIX cycle (started in 2010). Retrieved May 5, 2017 from http://komuna.warszawa.pl/1998/12/12/re-mix-cycle-20102011/

Lorek-Jezińska, E. (2013). Hauntology and intertextuality in contemporary British drama by women playwrights. Torun, Poland: Nicolaus Copernicus University Press.

Łuksza, A. (2014). Próba zapisu: Komuna//Warszawa: Paradise Now? RE//MIX Living Theatre. In T. Plata \& D. Sajewska (Eds.), RE//MIX: Performans i dokumentacja (pp. 213-217). Warsaw, Poland: Wydawnictwo Krytyki Politycznej.

Navas, E. (2012). Remix theory: The aesthetics of sampling. Vienna, Austria: Springer.

Pasquier, M.-C. (1987). Wspótczesny teatr amerykański. (E. Radziwiłłowa, Trans.). Warsaw, Poland: Państwowy Instytut Wydawniczy.

Phelan, P. (1993). Unmarked: The politics of performance. London, UK: Routledge.

Plata, T., \& Sajewska, D. (2014). RE//MIX Intro. In T. Plata \& D. Sajewska (Eds.), RE//MIX: Performans i dokumentacja (pp. 9-17). Warsaw, Poland: Wydawnictwo Krytyki Politycznej.

Roose-Evans, J. (1973). Experimental theatre: From Stanislavsky to Peter Brook. London, UK: Studio Vista.

Turner, V. (1982). From ritual to theatre: The human seriousness of play. New York, NY: Performing Arts Journal Publications.

Tylell, J. (1995). The living theatre: Art, exile and outrage. New York, NY: Grove Press.

Weinstock, J. A. (2013). Introduction: The spectral turn. In M. del Pilar Blanco \& E. Peeren (Eds.), Spectralities reader: Ghosts and haunting in contemporary cultural theory (pp. 62-63). London, UK: Bloomsbury.

Wolfreys, J. (2002). Victorian hauntings: Spectrality, Gothic, the uncanny and literature. Basingstoke, UK: Palgrave. 


\title{
Spectral-Fragile-(Un)homely: \\ The Haunting Presence of Francesca Woodman in the House and Space $^{2}$ Series
}

\author{
Anna Kisiel \\ University of Silesia in Katowice \\ kisiel.anna@outlook.com \\ Received 5 March 2017; accepted 8 October 2017.
}

\begin{abstract}
In the House and Space ${ }^{2}$ photographic series, Francesca Woodman captures the environments that may be considered disruptive; still, it is a female model —in her inconstant poses, always partially blurred or hidden - that holds the viewer's attention. The pictures therefore evoke a twofold sense of obscurity, since their unfriendly interiors are occupied by the uncanny, semi-absent yet ceaselessly present, dis-appearing woman, who turns out to be Woodman herself. Woodman's spectral presence and the unhomely locations she haunts - being simultaneously the photographer and the object of her photographs - are examined in this article by means of Bracha L. Ettinger's matrixial theory. Ettingerian psychoanalysis, juxtaposed with Roland Barthes, Sigmund Freud, and Jacques Lacan, provides the tools to challenge the dominant non-affirmative understanding of Woodman's self-portraits as works of disappearing and failing subjectivity: an understanding whose obvious point of support is found in the artist's biography. Instead, Ettinger's system makes it possible to look at this oeuvre through the prisms of fragility, homeliness, and the potential emergence of blurry, ghostly subjectivity. Moreover, the article examines the ways in which Woodman resists the divisions imposed on her and the medium she uses (such as the Barthesian triad of Operator, Spectator, and Spectrum, and the dichotomies of me / the Other and subject / object).
\end{abstract}

Keywords: Francesca Woodman; Bracha L. Ettinger; matrixial theory; the uncanny; homeliness; fragility; photography; blurry subjectivity. 


\section{Haunting Presence}

The title alone of Francesca Woodman's black and white photograph My House, taken in Providence, Rhode Island in 1976, may be associated with a homely space of intimacy and security - the place one belongs to (Woodman in Townsend, 2006, p. 105). Yet, when we confront it with the picture, it seems that these connotations do not fit. Instead of a supposedly friendly interior, we encounter a messy, chaotic, and ruined room, with plastic wrap scattered all over the floor. The room is, however, not empty. Its corner is occupied by a woman, probably naked, with a black hand, her whole body covered with plastic wrap. We are unable to see her clearly, as the plastic blurs the boundaries of her flesh and makes her face invisible. Her semi-presence disturbs both the inconstant interior and us, since it questions the stable distinctions we are used to.

Woodman, an American photographer born in 1958 to an artistic family, started taking pictures at the age of thirteen. She was a promising artist, who did not achieve success during her lifetime. In 1981 she committed suicide. Although her artistic activity was short, and the photographer herself was very young, her oeuvre consists of complex and haunting images, whose key motifs constitute a specific viewing experience. Her photographs are mainly black and white self-portraits. One of their most characteristic features is blur, caused by either movement or a long exposure time. Another co-emerging motif is a female model, often nude, fusing with devastated or uncanny surroundings. Despite the inconstant scene, the woman herself frequently appears to be delicate and vulnerable. These elements contribute to the intriguing character of her pictures.

The aim of this article is twofold. First, Woodman's House and Space ${ }^{2}$ photographic series will be explored with regard to the model's spectral existence and the locations she haunts. Second, the ways in which Woodman challenges the divisions imposed on her and the medium she uses will be investigated. I intend to examine Woodman's self-depictions and comment upon them by means of the tools provided by Bracha L. Ettinger's matrixial theory, believing that this system enriches possible Barthesian, Freudian, and Lacanian readings of these photographs; the aforementioned theorists will simultaneously serve the purpose of contextualising the Ettingerian intervention in the fields of psychoanalysis and aesthetics. Woodman's oeuvre will be looked at through the prisms of fragility, homeliness, and the potential emergence of blurry subjectivity, grounded upon connectedness instead of separation, castration, and lack.

Just as the viewer is haunted by Woodman's partially absent yet ceaselessly present female figure, so is her photography by non-affirmative critiques, often labelling it as "suicide art." In "Francesca Woodman's Photography: Death and the Image One More

Time," Peggy Phelan argues that Woodman's suicide may be her final artistic act. Analysing Woodman in the context of Freudian-Lacanian psychoanalysis, and Barthes's and Benjamin's views on the essence of photography, Phelan identifies her self-portraiture as "a way to rehearse her own death" (2002, p. 987). Margaret Sundell continues the psychoanalytical reading, proposing that the artist's works are repetitive narcissistic re-entries into the moment in which the self is in tension with its surroundings (1996, pp. 437-438). 
This thesis is reconsidered in Jui-Ch'i Liu's "Francesca Woodman's Self-Images: Transforming Bodies in the Space of Femininity" (2004). Liu claims that there is one distinguishing and crucial element of the photographer's oeuvre which is not emphasised sufficiently in the aforementioned text - a desire and dynamic attempt to "[reunite] with the maternal source" (Liu, 2004, p. 27). ${ }^{1}$ The tropes which resurface in the above readings are death, disappearance, and return to the maternal sphere, the last one connoting symbiosis, fusion, or psychosis in the psychoanalytical discourse. This article aspires to reconsider such approaches. Instead of remaining within the tradition of understanding Woodman's photographs as works of perishing or failing subjectivity (which can be easily supported when one takes the artist's biography into account), I will endeavour to indicate a different interpretative path, paved by Ettinger's theoretical writings.

Bracha L. Ettinger's matrixial theory eludes - and questions the primacy of - the dichotomous frame of classical Phallus-grounded theories, yet without rejecting these systems. She develops the notion of the Matrix, returning to the Latin roots of the word, associating it with the womb (see Ettinger, 2006a, p. 64). The womb is identified in this theory as an archaic space of difference and encounter, whose participants influence each other. Within such a space, boundaries of the self either are not yet completely fixed or lose significance because of the experienced proximity. The Matrix is claimed to reflect these attributes of the womb, and it simultaneously transfers the female organ "from nature to culture" (Ettinger, 2006b, p. 181). ${ }^{2}$ This founding concept of the Ettingerian system is defined as a prenatal signifier of originary feminine difference, and a psychic space of encounter of the $I$ and the non-I. The Matrix does not form the binary opposition to the Phallus; rather, it is a supplementary signifier, expanding the scope of the Symbolic order. ${ }^{3}$ The underpinnings of this theoretical intervention are feminine corporeality (in particular, pregnancy and intrauterine experience), and Ettinger's clinical practice, experiences of belonging to the Second Generation after the Holocaust, and artistic activity. Inspired by the intrauterine sphere and maternity, Ettinger claims that the primary instance of subjectivity is an encounter, which is a notion that challenges the primacy of separation present in Freudian

\footnotetext{
${ }^{1}$ Liu describes Woodman's desire as "active" in order to emphasise the contrast between her photographs and Man Ray's Retour à la raison (which is argued to be a depiction of the female body passively absorbed by its surroundings); nevertheless, what is at stake is the desire for fusion - an attribute that in the phallocentric thought is ascribed to the feminine (Liu, 2004, pp. 27-29).

${ }^{2}$ The relationship between "nature" and "culture," or between the womb and the Matrix, echoes the relation between the penis and the Phallus in classical psychoanalysis. Ettinger clarifies: "The womb and the prenatal phase are the referents to the Real to which the imaginary Matrix corresponds. But as a concept, the Matrix is no more - but no less - related to the womb than the Phallus is related to the penis. That is, Matrix is a symbolic concept" (Ettinger, 1993 as cited in Pollock, 2006b, p. 17).

${ }^{3}$ For a study of the matrixial feminine difference and its resistance to the phallic binary logic, see Pollock (2009, pp. 9-10). For a thorough examination of the evolution of the concept of the Matrix in Ettinger's work and its various aspects, see Pollock (2006b, pp. 12-21).
} 
and Lacanian paradigms. In her view, the subjectivising process is foundationally affirmative before - but also beyond - the postnatal period, during which a series of cuts prevails in shaping the $I$ (see Ettinger, 2006a, pp. 84-85). ${ }^{4}$ Thereby, subjectivity-as-encounter - as Ettinger names it -implies transmission, shareability, and intimate transformation between two (or more) subjects. Ettinger delineates this paradoxical subjectivising stratum as follows: "In subjectivity-as-encounter-where an-other is not an absolute separate Other-[relations-without-relating] turn both of us into partial-subjects, still uncognized, thoughtlessly known to each other, matrixially knowing each other, in painful fragility" (Ettinger, 2006c, p. 144). The issue of encounter is tightly linked to Ettinger's artistic practice. Ettinger claims that an encounter with art may generate the possibility of proximity and participation, and associates such a meeting with wit(h)nessing - a sense of unexpected and irreducible closeness provoked by the artwork in the sphere not mastered by phallic paradigms (Ettinger, 2006c, pp. 148-151). The matrixial is then an almostunbounded space of connectivity which, however, cannot be mistakenly taken for symbiosis and fusion, as they exclude any possibility of subjectivity. ${ }^{5}$ This stratum may become accessible only through precarious acts of fragilising, opening, and exposing oneself to the Other (Ettinger, 2006c, p. 152).

The dominant view on Woodman's art can be challenged by means of Ettinger's theory, whose postulates provoke an affirmative assessment of it. ${ }^{6}$ Having briefly introduced the main assumptions of the matrixial psychoanalysis, in the following sections I will employ several Ettingerian concepts for the purpose of examining the House and Space ${ }^{2}$ series; I will also juxtapose these concepts with Barthes, Freud, and Lacan to broaden both interpretative and theoretical frameworks. Self-fragilisation may be seen as one of the conditions of re-entering the matrixial borderspace; it is an act of becoming vulnerable when facing the Other, opening one's boundaries, and, in a sense, preparing for a transformation, implicit in a matrixial encounter. This notion is inextricably linked to resistance, which in Ettingerian terminology covers withstanding the phallic urge to set clear borders between

\footnotetext{
${ }^{4}$ It does not, however, mean that the matrixial stratum of subjectivity disappears after birth, which would imply that the Matrix is exclusively prenatal. Rather, it gives way to the phallic subjectifying stratum while co-existing with it (Ettinger, 2006a, pp. 84-85). It can occasionally resurface in certain conditions, for instance provoked by with)nessing, which is going to be briefly discussed below.

${ }^{5}$ Griselda Pollock clarifies that the matrixial borderspace is grounded upon two (or more) subjects "sharing space but never fusing, encountering but never dissolving their boundaries, jointly eventing without ever knowing fully the other's event" (Pollock, 2009, p. 14).

${ }^{6}$ A remarkable affirmative re-reading of Woodman's art is proposed by Claire Raymond in Francesca Woodman and the Kantian Sublime (2010). Questioning the validity of looking at Woodman's oeuvre through the prism of her death, Raymond instead focuses on the American photographer as a sui generis theoretician of the Kantian notion of the sublime, in a sense that "[her] photographs are not passive receptacles of aesthetic theory but rather interrogate, alter, and generate that theory" (Raymond, 2016, p. 3). In her study of Woodman's exploration of the medium of photography and the recurring motifs of blur, space / architecture, gendered flesh, and the gaze, Raymond turns also to Bracha L. Ettinger; however, the matrixial theory becomes a briefly mentioned context rather than a tool (see Raymond, 2016, p. 32). The matrixial approach-if adopted to a greater degree-takes us to a new territory in the reception of Woodman's work.
} 
self and the Other, and, often, to objectify the Other. Finally, Ettinger's re-reading of Freudian uncanny - a term that becomes one of the foundations of the theory of the Matrix-will be commented upon in the context of matrixial subjectivity.

\section{Fragilisation in the House Series}

House \#3, taken in Providence, Rhode Island in 1976, corresponding in style and themes to the previously mentioned My House photograph, is one of Woodman's pictures in which seemingly clear-cut distinctions become vague (Woodman in Townsend, 2006, p. 107). The eponymous house is dilapidated, as if abandoned, and on the floor we can see broken pieces. These items and strong, contrasting light produce the feeling of inconstancy, although the image itself is sharp. In fact, only one element of the whole scene is blurred: a woman, hidden under the window frame. She is covered with fragments of wallpaper, whereas a long exposure time, along with the model's movement, creates an impression of her merging with the surroundings. Such a linkage constitutes a sense of belonging - or rather of an attempt to belong - to the place. This peculiar urge to connect with the environment appears to reflect the desire to resist the limitations of the body, which in this case is the female body. We may thus assume that the photograph captures the search for subjectivity in a vulnerable and inconstant sphere. Such a struggle to transcend one's corporeality is far from being passive, since the model's movement responsible for the creation of the blurry photograph is not the only dynamic element of it. When the viewer looks closely ${ }^{7}$ at the shades that compose the woman's dim face, he or she notices her eyes, gazing at the camera. The model resists both the passivity of fusing with the surroundings and the possibility of becoming an object of the image: she is not merely to be looked at, as she gazes back at the viewer, mastering the space within the photographic frame and affirming her relentless presence.

This subjectifying act witnessed in the picture places Woodman in opposition to Roland Barthes's assumption that the portrait-taking activity may be linked with objectification: namely, that it represents the disquieting moment when the model is "neither subject nor object but a subject who feels he [or she] is becoming an object" (Barthes, 1981, p. 14). Thus, in Barthes's thought, the depicted person is a phantom unable to control the viewers' possible interpretations: a phantom experiencing "a micro-version of death" (1981, p. 14). ${ }^{8}$ The artist also seems to disagree with the Barthesian triad of Spectator, Operator, and Spectrum imposed on photography. In Camera Lucida, Barthes suggests that the Operator's - that is, the photographer's - attitude towards picture-taking may be associated with

\footnotetext{
${ }^{7}$ For further reflections on the activity of looking at Woodman's photographs, see Simon (2010, pp. 28-35). The author argues that the size of Woodman's self-depictions requires a closer look from the viewer and thus creates a different-more intimate-viewing experience.

${ }^{8}$ There is, however, one element that Barthes considers pleasurable in the whole act - namely, it is the sound that the camera produces when the picture is being taken. As the theorist insists, it interrupts the deadly pose (Barthes, 1981, p. 15).
} 
the physical process of looking through the optical device, and thus enforcing his or her vision (1981, pp. 9-10). Even though he emphasises that he has never explored this perspective, his understanding of the issue appears to be strikingly simplifying: the artist is reduced to the viewfinder's gaze. It becomes even more inaccurate when Woodman's oeuvre is taken into consideration, for she cannot be restricted to the Operator's perspective. In fact, she is also the Spectrum, described by Barthes as the object captured in the photograph, whose name in his nomenclature not without reason implies spectrality, theatricality, and passing. He explains the assigned name by indicating its reference to the spectacle, which "adds to it that rather terrible thing which is there in every photograph: the return of the dead" (Barthes, 1981, p. 9). When asked about the reason why she appeared in most of her works, Woodman said, "It's a matter of convenience, I'm always available" (Rankin, 1998 , p. 35). Yet, it may not be the only factor. Her appearance in self-depictions is the trace of the seemingly explicit boundaries between the artist and the model which are becoming blurry. It is no longer a binary choice: she fuses these two perspectives. ${ }^{9}$ Still, we must not forget the third element of the Barthesian triad - the Spectator. Woodman, who simultaneously embodies the aforementioned figures, is the one who gazes at the effects of such cooperation as well. Therefore, she goes beyond the division; she not only encompasses but also transcends each element of the triad.

While for Barthes the Spectrum is at risk of being objectified or losing control entirely, the matrixial angle excludes these options. The encounter between the viewer and the Spectrum of the photograph can be portrayed by Ettinger's notion of self-fragilisation. It is an integral process of entering the matrixial stratum, in which "the subject encounters the other, and realizes its vulnerability, while resisting its own tendency to turn the other into an object and to return to its own paranoid abjectivity and narcissistic passive aggressivity" (Ettinger, 2009, p. 4). Consequently, this process creates a chance to relate to the non-I not "as an intruder," but rather as "a partner-in-difference of the $I$ " (Ettinger, 2006a, pp. 64-65; emphasis in the original). Vulnerability and partialisation in the matrixial sense transform borders of the self - and, simultaneously, of art-into thresholds, making the Other a co-subject, instead of an object (Ettinger, 2006a, p. 56). Self-fragilisation eventuates in transcending the limits of sole witnessing; instead, one engages in wit(h)nessing. The subject is able to resist clear-cut boundaries and, as a result, to share and transform in the matrixial sphere of encounter. The notion of matrixial resistance differs from the general understanding of the word, since it is neither passive nor aggressive. As Ettinger claims, "[t]he subject must resist its own tendency to manipulate, appropriate, control and

\footnotetext{
${ }^{9}$ Claire Raymond proposes an interesting reading of Woodman's ambiguous status. Comparing House \#3 to works by Victorian women photographers Julia Margaret Cameron and Clementina Hawarden depicting children, Raymond notes that Woodman challenges the theme of the maternal gaze (Raymond, 2016, pp. 22-24). We read that "in Woodman's image the daughter seems to be trying to protect herself, belatedly, from the audience. Woodman, the photographer of this portrait as well as the subject, complicates matters of self-protection in the image. In this transference and duality of roles, she enacts the maternal gaze and acts the daughter's body, picturing the daughter as sacrificial object in the controlled time frame of the photograph, that image to which she herself is the first implicit witness" (Raymond, 2016, p. 24).
} 
abandon, and engage itself in an active struggle against its own paranoia, if 'its' I and nonI are to continue coemerging" $(2009$, p. 19). Therefore, these two contradictive paths cannot be reconciled, as resistance has an affirmative charge: it is "a working for, not against: a re-working for trust, again and again" (Ettinger, 2009, p. 19). This process is hence associated with both self-fragilisation and intimate proximity: proximity with oneself and openness towards others simultaneously. To resist is to relinquish one's boundaries and restrictions imposed by phallic aspects of one's subjectivity; this is the act of surrendering to the matrixial intimacy. Returning to House \#3, the woman in the picture does not simply reconcile; she engages in the creation of a private sphere. In an Ettingerian sense, she resists the imposed limitations, simultaneously endeavouring to transcend them. The female makes herself vulnerable, challenging her own bodily boundaries and opening herself for the experience of being together. Her resistance is not directed against the Other, nor is it passive; rather, it supports the trans-formation of blurry and fragile subjectivity.

The theme of fragilising oneself in an unstable yet intimate space is continued in House \#4 from 1976 (Woodman in Townsend, 2006, p. 108). The unnatural, defamiliarised perspective and the seemingly crooked walls create a claustrophobic impression. The central female figure is fuzzy and partly hidden behind the mantel of a fireplace. Even though in this situation we do not encounter her gaze, the image is dynamic in itself, for the model is captured in an act of quasi-fusing with the scene. ${ }^{10}$ Therefore, the house once more becomes the vehicle to transcend the self. The model is blurred and in a sense partialised by the mantel. Yet, there is one constant element visible - contrarily to the rest of the body, her feet are sharp, being the only body parts resisting the complete disappearance. This detail leads us to the crucial matrixial implication: blurry subjectivity does not depend on losing oneself. The matrixial stratum is based on wit(h)nessing - the act of sharing and transforming each other - and, thus, on becoming vulnerable. However, in the matrixial stratum it is not an act against the self, but rather an opportunity, since self-fragilisation is a dynamic path towards subjectivity-as-encounter: subjectivity constituted in togetherness.

\section{Homeliness in the $\operatorname{Space}^{2}$ Series}

In the pictures analysed above, one of the essential elements is the process of connecting with the surroundings. The photograph from the $S_{p a c e}{ }^{2}$ series taken in Providence, Rhode Island in 1976 presents a different experience (Woodman in Townsend, 2006, p. 121). The background is no longer chaotic or fragmented - it is simplified. As a result, a woman becomes the main concern. In the picture, she does not try to establish a linkage with the environment. Yet, due to her movement, her head is completely blurred, hence

\footnotetext{
${ }^{10}$ Raymond provides us with a sui generis backstage insight into this photograph, informing us that the mantel was not originally in the room-it was brought there by Woodman and Sloan Rankin (Raymond, 2016, p. 27). The author concludes that "Woodman, the 'ghost,' actually taps the architectonic rhetoric of haunting, prepossessingly possessing the house" (Raymond, 2016, p. 27; emphasis mine). Therefore, the picture appears to be dynamic on a number of levels.
} 
the impossibility to see the model's face - a body part usually associated with one's identity. Looking at one's own portrait is identified by Roland Barthes as different from looking at a mirror. Via the medium of photography, he argues, a person sees himself or herself as someone else, which may cause anxiety (Barthes, 1981, pp. 12-13). ${ }^{11}$ A similar dualism, yet interpreted differently, can be traced in Jacques Lacan's mirror stage. When a becoming subject recognises its face in the mirror for the first time, together with the full spectrum of its body, it acknowledges the reflection as other than itself, and yet identifies with this picture. ${ }^{12}$ In Emmanuel Levinas, in turn, the face establishes the ethical relationship with the Other; the encounter with the fragile, naked face of the Other is interpreted as the first one, introducing responsibility, but not partnership or dialogue (see Levinas, 1969). For all three theorists, the face is presented as a fundamental element of the process of becoming a subject; in $S_{p a c e}{ }^{2}$, however, it is the face that loses clarity. In this photograph Francesca Woodman captures the invisible — an image she is not able to see in the mirror. This phenomenon corresponds to Lacan's notion of the Real, an "indivisible brute materiality" (Homer, 2005, p. 82). Since the Real eludes representation, Lacan notes that the encounter with it is "essentially the missed encounter" (Lacan, 1981, p. 55), which cannot be symbolised, comprehended, or mastered. Via the medium of photography, Woodman appears to gain a momentary access to the impossible image of her face in movement. What we wit(h)ness is, to use Ettinger's expression, an "almost-impossible encounter" (2006c, p. 152) with the Real of the blurred faciality. Woodman does not allow mis-recognition or objectification in her spectral project; instead, via the rehearsal of her body and the visual possibilities of the medium, she tries to grasp that which goes beyond representation. ${ }^{13}$

Where does Woodman's entanglement in the play of dis-appearance lead us? In another picture from the Space ${ }^{2}$ series, taken between 1975 and 1976, we re-encounter a female model, whose naked body is captured in a standstill, including hands and feet (Woodman in Townsend, 2006, p. 118). Yet, her face is blurred due to the rapid movement of her head, similarly to the previously shown photograph from the same series. She poses in an empty room, except for the receptacle resembling an aquarium, within which most of her body remains. She clings to the glass wall and only her left hand reaches out to touch the outer surface. The transparent box is to make her fully visible, but she does not try to hide. Simultaneously, she does not attempt to appropriate the space. Rather, she examines its boundaries with her hands and skin. Neither present nor absent but somewhere in between, her ghostly figure resists the stability and lucidity of the occupied place.

\footnotetext{
${ }^{11}$ Barthes further associates such disquietude with a theme of the double, as a disturbing mythic element of the pre-photographic times.

${ }^{12}$ See Lacan (2006, pp. 75-81). For more information about photography in the context of Lacan, see Iskin (1997, pp. 43-66).

${ }^{13}$ Interestingly, Griselda Pollock diagnoses Bracha L. Ettinger's art as "[directing] us aesthetically away from content towards gesture" (2013, p. 3; emphasis in the original), which appears to be applicable also to Francesca Woodman's images, concerned less with representation and more with a rehearsal of boundaries of the medium of photography and her own corporeality as a model.
} 
While observing the space in the above picture, we may recall Freud's famous notion of the uncanny. The interior, in particular the cuboid, is far from being intimate or cosy; instead, it is raw and revealing. Despite such striking transparency, the viewer can experience twofold unease. On the one hand, one can feel that this scene ought not to be gazed at - that somehow the act of looking violates undefined privacy, balancing on the edge of voyeurism. On the other, the face of the woman remains concealed, leaving the spectator unfulfilled. Yet, as Freud notes, referring to the etymology of the uncanny, "Unheimlich is in some way or other a sub-species of heimlich" (2001, p. 226; emphasis in the original). When discussing the ambiguity of the term, in both language and psychoanalysis, Freud claims that uncanniness is not about fear in itself; it concerns the return of something that should have been left in the state of being unremembered: a repressed experience that used to be familiar. He clarifies it on the example of some people's fear of waking up in a coffin, realising they have been buried alive: "And yet psycho-analysis has taught us that this terrifying phantasy is only a transformation of another phantasy which had originally nothing terrifying about it at all, but was qualified by a certain lasciviousness - the phantasy, I mean, of intra-uterine existence" (2001, p. 244). Freud therefore makes a difference between experiences that cause anxiety twice - before repression and as a result of it - and ones that provoke anxiety only when repressed. The other type is connected with the female body, identified as at the same time homely, originary, and universal - as it is the site where all human beings emerge - and uncanny (Freud, 2001, p. 245).

The uncanny has a major influence on two Ettingerian notions - the matrixial complex and matrixial co-subjectivity. When discussing the Freudian distinction into two types of experiences causing anxiety, Ettinger points out that in the latter one, associated with feminine corporeality, we can trace the matrixial — or maternal womb / intrauterinecomplex (Ettinger, 2006a, p. 47). Having linked this concept to the matrixial phantasy, the theorist observes:

While castration phantasy is frightening at the point of the emergence of the original experience before its repression, the matrixial phantasy (from matrice, for womb) is not frightening at the point of its original emergence, but becomes frightening when the experience is repressed... Thus for both complexes the same affect, that of anxiety, accompanies the return of the repressed. (Ettinger, 2006a, p. 47; emphasis in the original)

This excerpt demonstrates Ettinger's indebtedness to Freud's account of the uncanny, but also her attempts to fill the blank spots of classical psychoanalysis concerning femininity. ${ }^{14}$ The ambiguous structure of the uncanny is also implicit in the Ettingerian notion of matrixial subjectivity. As it has been mentioned before, one of Ettinger's inspirations is the intrauterine phase along with the encounter-event of pregnancy. Griselda Pollock stresses that

\footnotetext{
${ }^{14}$ For Ettinger's analysis of the uncanny in Freud and its significance for the matrixial theory, see Ettinger (2006a, pp. 41-90).
} 
[t]here is nothing cosy about the situation of matrixial co-subjectivity. It is the pathway of transmitted trauma, hatred, anxiety, or fear as much as it can become the basis for theorizing the way in which what is not me can none the less affect me, and in which I can handle affects that are not mine. (2006a, p. 109; emphasis mine)

Matrixial subjectivity is thus not blissful and friendly per se, but distressing, as it provides the opportunity to sense the traces of the Other's experiences. This originary type of subjectivity formation - beyond and before Oedipus and castration - is grounded upon encounter, proximity, fragility, and openness, precariously close to fusion. It is ambiguously Un-heimlich: both homely and disruptive, simultaneously humanising and traumatising, and never singular, as it is made possible only in togetherness.

\section{Spectral Togetherness}

This article has explored Francesca Woodman's spectral art, with special emphasis put on such issues as resistance to distinctions (including the Barthesian triad, and dichotomies of me vs. the Other and subject vs. object) and the emergence of another kind of subjectivity. Barthes's search for the essence of photography, Lacanian mirror phase, Levinasian reflections on an encounter with the face, and Freud's conceptualisation of the uncanny have paved the way for challenging the dominant readings Woodman's indefinite, ghostly images from House and Space ${ }^{2}$ series are subject to. I have turned to Bracha L. Ettinger's reconsideration of psychoanalysis in such notions as self-fragilisation, resistance, and matrixial subjectivity so as to show that Woodman's disruptive photographs can-and, indeed, should - be interpreted in an affirmative frame, since they can provide the space for blurry subjectivity based on togetherness, non-passivity, and vulnerability.

Francesca Woodman returns, over and over again, to the spaces that seem to be neither homely nor friendly, and yet there is something familiar in them. Never complete, always almost-present, almost-in-flesh, she haunts these locations in order to establish linkages with them. Although she sacrifices a part of her-self while becoming a spectral, fragile, and un-homely figure, what she gains is a tangible connection with the sphere in which seemingly stable borderlines — of her body, of space, of art, of the discourse-lose relevance.

\section{References}

Barthes, R. (1981). Camera lucida: Reflections on photography. (R. Howard, Trans.). New York, NY: Hill and Wang.

Ettinger, B. L. (1993). Woman-other-thing: A matrixial touch. In B. L. Ettinger. Matrix - Borderlines (pp. 11-18). Oxford, UK: Museum of Modern Art.

Ettinger, B. L. (2006a). The matrixial gaze. In B. L. Ettinger, The matrixial borderspace (pp. 41-90). B. Massumi (Ed.). Minneapolis: University of Minnesota Press. 
Ettinger, B. L. (2006b). Weaving a woman artist with-in the matrixial encounter-event. In B. L. Ettinger, The matrixial borderspace (pp. 173-198). B. Massumi (Ed.). Minneapolis: University of Minnesota Press.

Ettinger, B. L. (2006c). Wit(h)nessing trauma and the matrixial gaze. In B. L. Ettinger, The matrixial borderspace (pp. 123-155). B. Massumi (Ed.). Minneapolis: University of Minnesota Press.

Ettinger, B. L. (2009). Fragilization and resistance. Studies in the Maternal, 1(2). Retrieved April 16, 2013 from http://www.mamsie.bbk.ac.uk/back_issues/issue_two/documents/Bracha1.pdf

Freud, S. (2001). The 'uncanny'. In S. Freud, The standard edition of the complete psychological works of Sigmund Freud. Volume XVII (1917-1919) (pp. 219-252). (J. Strachey \& A. Freud, Trans.). London, UK: Vintage Books, Hogarth Press, and The Institute of Psychoanalysis.

Homer, S. (2005). Jacques Lacan. London, UK: Routledge.

Iskin, R. E. (1997). In the light of images and the shadow of technology: Lacan, photography and subjectivity. Discourse, 19(3): 43-66.

Lacan, J. (1981). Tuché and automaton. In J. Lacan, The seminar of Jacques Lacan. Book XI: The four fundamental concepts of psychoanalysis. J.-A. Miller, (Ed.). (A. Sheridan, Trans.). New York, NY: W. W. Norton \& Company: 53-64.

Lacan, J. (2006). The mirror stage as formative of the $I$ function as revealed in psychoanalytic experience. In J. Lacan, Écrits (pp. 75-81). (B. Fink, H. Fink, \& R. Grigg, Trans.). London, UK: W. W. Norton \& Company.

Levinas, E. (1969). Totality and infinity: An essay on exteriority. (A. Lingis, Trans.). Pittsburgh, PA: Duquesne University Press.

Liu, J.-C. (2004). Francesca Woodman's self-images: Transforming bodies in the space of femininity. Woman's Art Journal, 25(1), 26-31.

Phelan, P. (2002). Francesca Woodman's photography: Death and the image one more time. Signs, 27(4), 979-1004.

Pollock, G. (2006a). Beyond Oedipus: Feminist thought, psychoanalysis, and mythical figurations of the feminine. In V. Zajko \& M. Leonard (Eds.), Laughing with Medusa: Classical myth and feminist thought (pp. 67-117). Oxford, UK: Oxford University Press.

Pollock, G. (2006b). Introduction. Femininity: Aporia or sexual difference? In B. L. Ettinger, The matrixial borderspace (pp. 1-38). B. Massumi (Ed.). Minneapolis: University of Minnesota Press.

Pollock, G. (2009). Mother trouble: The maternal-feminine in phallic and feminist theory in relation to Bracha Ettinger's elaboration of matrixial ethics/aesthetics. Studies in the Maternal, 1(1). Retrieved November 29, 2013 from http://www.mamsie.bbk.ac.uk/back_issues/issue_one/ GriseldaPollock.pdf

Pollock, G. (2013). After-affects / after-images: Trauma and aesthetic transformation in the virtual feminist museum. Manchester, UK: Manchester University Press.

Rankin, S. (1998). Peach mumble-Ideas cooking. In H. Chandès (Ed.), Francesca Woodman (pp. 33-40). Paris, France: Fondation Cartier pour l'art contemporain and Scalo.

Raymond, C. (2016). Francesca Woodman and the Kantian sublime. London, UK: Routledge. 
Simon, J. (2010). An intimate mode of looking: Francesca Woodman's photographs. Emotion, Space and Society, 3, 28-35.

Sundell, M. (1996). Vanishing points: The photography of Francesca Woodman. In M. C. de Zegher, (Ed.), Inside the visible: An elliptical traverse of $20^{\text {th }}$ century art in, of, and from the feminine (pp. 435-439). Cambridge, MA: MIT Press.

Townsend, C. (2006). Francesca Woodman. London, UK: Phaidon Press. 


\title{
Hauntology of Responsibility: Tom Stoppard's Darkside
}

\author{
Tymon Adamczewski \\ Kazimierz Wielki University in Bydgoszcz \\ tymon.adamczewski@ukw.edu.pl
}

Received 24 March 2017; accepted 5 October 2017.

\begin{abstract}
The article centres on the notion of responsibility in Tom Stoppard's Darkside (2013). While Pink Floyd's original album, which inspired the playwright, thematises its connection to ethics in a spectral and hauntological manner, through the use of field recording sound snippets interwoven in the music, the radio play explores the notion of responsibility through what is called "thought experiments." The article identifies the subversive function of these narrative examples and, following Emanuel Levinas' suggestions concerning the instability of the link between the philosophical discourse and that of examples, shows the latter's insolent and disruptive nature. The notion of responsibility is further linked to its discussion by Jacques Derrida in his Gift of Death (1995) which consequently makes it possible to view the relation between responsibility and responding from a subversive, hauntological and undecidable perspective.
\end{abstract}

Keywords: ethics; responsibility; Jacques Derrida; Tom Stoppard; music.

Darkside is a radio play by Tom Stoppard, the Czech-born British playwright, commissioned for BBC Radio 2. First broadcast on 26 August 2013 to celebrate the $40^{\text {th }}$ anniversary of Pink Floyd's Dark Side of the Moon, this radio comedy drama incorporates the music from the original record, Roger Waters' lyrics and Stoppard's own ideas in the form inspired by diverse aspects of the musical material. The record, often considered as a pinnacle achievement of the group, ranks among the most popular and instantly recognizable concept albums in contemporary popular culture. Its landmark position stems from various reasons, ranging from minimalistic yet iconic record sleeve, pioneering sound engineering (use of innovative recording techniques, like multi-track or loops), or the way music, typically for the group, is intertwined with snippets of field recording (voices, sound effects, etc.). In fact, it is the sounds, apart from the philosophical themes of time, ageing, critique of 
materialism, consumerism or madness of contemporary life expressed in the lyrics that seem to haunt the album and constitute a spectral trait of both the recording and the play.

While partly accounting for the album's unwaning popularity, the haunting traits are noticeable already at the structural level of the recording and in many cases contribute to the resistance to semantic closure. Recorded voices, laughter, sounds of heartbeat (which open and close the album) - all such effects trouble the listener and challenge the very perception of what otherwise might simply be popular music. While discussing similar yet immediately spectral sounds like the high-pitched violin or white noise, Isabella van Elferen (2012), in her book on Gothic Music and the uncanny, points out that effects like these suggest a certain ghostly presence, "even when this presence is invisible or intangible" (2012, p. 4). Such elements "undermine closure" in musical reception and produce the effect which van Elferen terms "the sense of uncanniness in sonic liminality"-leading to the claim that "Gothic music is always spectral" (2012, p. 4). This qualification can actually be extended onto Pink Floyd's work, however, with the reservation that, although their music is not gothic music, the use of the real-world sound snippets ("I never said I was afraid of dying") produces the effect of spectral presence. In other words, even though Pink Floyd's record, despite its popularity, is not an example of classic pop music, it is the idea of "openness," or "undermined closure" which accounts for the spectral aspects of their music. Interestingly, among such traits are links to the ethical category of responsibility and ethics in general which, both, (re)appear throughout the musical work and Stoppard's radio play, thereby inviting a hauntological reading.

Responsibility, indeed, also seems to be a hauntologically hazy phenomenon. Paul Ricoeur, for example, speaks about this notion not only as a fairly recent one, and "not really well established within the philosophical tradition," but also as one inviting "a kind of vagueness [which] invades the conceptual scene" (2000, p. 11). Part of this ambiguity comes from an understanding of responsibility as an obligation - to "fulfill certain duties, to assume certain burdens, to carry out certain commitments," but also from the very "polysemy of the verb "to respond" taken as an answer as well as a response to "a question, an appeal, an injunction" (2000, p. 12). If we then consider responsibility as a state of being accountable for some action or event, such understanding of the notion can easily be identified at various levels of both texts (the record and the play). Both of them - in more than simply formal sense - seem influenced by the spectral quality of an ethical obligation: both rely on aural signification which seems to thematize the notion of responsibility either as small-scale embedded narratives, dialogues, or lyrics and real-life noises, fading in and out of the soundscape in a spectral way. Ethical terms seem thus to underlie much of the material not only in its content but in some cases in the very way in which the musicians were working on the album. Famous are the stories how during the recording sessions Waters recruited the staff, the temporary occupants of the studio and roadies to answer a series of questions printed on flashcards. These were ranging from general questions about a favourite colour to more specific ones, for example about the last time they were violent. The recorded answers were later on included in the final album. One such instance has the following form: 
HuHuh! I was in the right!

Yes, absolutely in the right!

I certainly was in the right!

You was definitely in the right. That geezer was cruising for a bruising!

Yeah!

Why does anyone do anything?

I don't know, I was really drunk at the time!

I was just telling him, he couldn't get into number 2. He was asking why he wasn't coming up on freely, after I was yelling and screaming and telling him why he wasn't coming up on freely. It came as a heavy blow, but we sorted the matter out.

(Pink Floyd, "Money", from 5:57 approx.)

It is in response to the question about moral qualification of the speaker's actions (being in the right) that the notion of responsibility appears. Interestingly, it functions within an ethical perspective and seems to haunt the person while at the same time indicating a certain spectral quality of responsibility. The recurring presence of other similar recorded responses and sounds, often barely audible on the album, shows how the record seems to act out an "unfamiliarly familiar" presence which might be connected with the quality of contemporary life. According to Sheila Whiteley:

The words act like dialogue over the music, impressionistic yet making a point. As the album deals with stress, lunacy and death in contemporary society, so the disembodied vocal timbres create effective commentary: cynical asides and taped effects underline the inhuman quality still further by creating an abstract collage against which to project the emptiness of modern life; while the electronic treatment of instrumental and vocal sounds helps to reinforce the distancing of space as signified through pure tone, electronically synthesized. (Whiteley, 2005, p. 117)

In his lyrics, Waters thus thematises its perception in the tradition of modernist cultural pessimism as, among other things, a set of recurrent images (cf. Weinstein, 2002) which could, in turn, be construed as a reading of how people's decisions and their actions seem to come back to them.

The plot of Stoppard's Darkside is loosely based on the outwardly philosophical themes of Pink Floyd's album. It is a story of Emily McCoy, a student of philosophy and a patient in an institution resembling an insane asylum run by Dr Antrobus who is administering her treatment. The generally linear story is presented through a series of scenes, corresponding to the tracks on the album, and constitutes an exploration of ethical and moral dilemmas referred to as "thought experiments." These have the form resembling smallscale exemplary narratives illustrating some ethical problems, initially discussed in a philosophy course Emily is attending. The stories in question, however, are often problematised either by the main character's responses to them, or by the fact that the characters of these stories are brought to life and have to live through the consequences of the ethical 
dilemmas posed within such narratives. In the course of the play Emily interacts in various ways with such characters. In the opening scene, for example, we encounter Ethics Man who, after being introduced in the "American comic-book style," switches points and sacrifices the life of a boy in order to save more human lives on a runaway train (Stoppard, 2013 , p. 7). Afterwards, we return to philosophy class where Mr Baggott — soon to be revealed as the Ethics Man himself-asks about the superhero's moral philosophy. Curiously enough Emily has substantial doubts about the whole narrative and asks follow-up questions about the details of the characters of the story: Who was on the train? Who was the boy who got hit by the train? (Stoppard, 2013, p. 9). This seems to dislodge the moral dilemmas from their usual functions within ethics as a discourse. Moreover, such narrative techniques which introduce an ethical problem only to propose a non-standard resolution (e.g. the use of common land example; Stoppard, 2013, pp. 24-25) not only establish an ironic angle to the story but also point to the fact that ethics seems to be at its vital centre.

Nevertheless, as it is visible from its very beginning, the play's understanding of ethics runs against the traditional definition of this philosophical discourse, where "ethics is the arena in which the claims of otherness - the moral law, the human other, cultural norms, the Good-in-itself - are articulated and negotiated" (Harpham, 1995, p. 394). In the play, ethics as a philosophical discourse on morality is reflected as a paradox. Emily is introduced as a philosophy student trying to learn about "moral actions, the just society . . . Plato, Rousseau, Immanuel Kant who questions the legitimacy or the very point of examples used as moral dilemmas" (Stoppard, 2013, p. 12). When she meets a Boy from one of the thought experiments her doubts about ever obtaining an answer or reaching some transcendental point of certainty become sealed. While speaking about the juggler on the radio (such transcendental presence), he confirms the helplessness of "philosopher-type people" who actually fail at providing any material attempts at clarifying the difference between "a juggler you can't see, hear, smell or touch" and no juggler at all; according to the Boy, "there's nothing any of these people can tell each other about the existence or the non-existence of the juggler" (Stoppard, 2013, p. 13). Such remarks seem to evoke the nature of the discipline which promises answers but instead is only obsessed with questions - like for example "how ought one live?" or "what ought one do?" (Harpham, 1995, p. 395). In other words, instead of providing solutions traditionally understood ethics turns out to rest on "articulating perplexity, rather than guiding" (Harpham, 1995, p. 395). Stoppard's Darkside reflects such paradoxical status of ethics through the thought experiments which constitute embedded narratives about moral choices. Their role, however, is certainly deconstructive as they act out the consequences of the example-stories only to dislodge the ethical discourse from its explanatory position.

In this respect, Stoppard's play may be taken as an attempt to get to grips with the philosophy's impact on human life, as it seems to have identified the problematic status of examples within ethical theory. On the one hand, as Geoffrey Harpham aptly points out, in such a discourse a "narrative serves as the necessary 'example,' with all the possibilities of servility, deflection, deformation, and insubordination that role implies" (1995, p. 401); on the other, moral philosophers, as the play also emphasises, are not exactly keen on 
advising on the properly moral course of action. Instead, what they focus on is just telling more stories. This, in turn, may stem from the very nature of an example; or even further, from the polyvalence of stories and language, because the example may be seen as introducing "an element of risk into the fabric of assertive discourse" (Davis, 2004, p. 88).

Such tradition of reluctance and reservation towards examples (often in the narrative form) can be evidenced with the work of philosophers representing disparate traditions of understanding ethics. One such case, concerning telling lies and an obligation to tell the truth, comes from Immanuel Kant. While illustrating how, despite being a violation of the categorical imperative, in some situations one has to tell a (benevolent) lie in order to save others (e.g. the story of a murderer inquiring about the whereabouts of a friend hiding in our house), the philosopher expresses his reluctance towards such exemplary stories or narratives (cf. Davis, 2004, pp. 87-89 et passim). Interestingly, a similar reluctance towards the use of narratives as examples can be found in the works of a philosopher representing a somewhat different approach to ethics and responsibility, namely Emmanuel Levinas. In the case of his works, the trouble with examples, and more widely with literature, stems from seeing narratives as embodying what might be termed as the structure of exemplarity. This may roughly indicate literature's ability to serve as an example of a world and the behaviour of its inhabitants (including their decisions). One should not find this particularly surprising, if for Jonathan Culler, for instance, this trait of literature may be seen as paradoxical in its own right:

The special structure of exemplarity at work in literature allows for the ease with which readers and critics come to speak about the "universality" of literature. Hamlet, for instance, presents itself as in some way exemplary ..., but it simultaneously declines to define the range or scope of that exemplarity. Hence the ease with which readers and critics come to speak about the "universality" of literature. The structure of literary works is such that it is easier to take them as telling us about "the human condition" in general than to specify what narrower categories they describe or illuminate. (Culler, 2000, p. 36)

Despite literature's propensity for activating universal features of literature (such as universal readings resulting, for example, in national canons), it is precisely this universal potential of exemplarity inherent in literature - in a way close to the poststructural semantic polyvalence of texts - that accounts, at least partly, for the problems ethical discourse has with narrative examples. The vexed nature of this relationship is visible in the sparse use of such exemplary stories in as disparate strands of ethics as the ones exemplified by Kant or Levinas. As Davis observes, Kant's reluctance to use examples stems from the risk that "they may reveal a weakness within his ethics; in Levinas' writing, on the other hand, weakness is disclosed by the absence of examples, related to a more general suspicion of narrative literature" (Davis, 2004, p. 101). What is interesting is that in both cases stories, narratives (and literature in general) connote a certain threat or something potentially dangerous to the coherence and integrity of what the philosophers are discussing.

Despite the overall reluctance towards examples and their effectivity, they may be seen as performing a "double function." In Levinas' readings of Talmud he states that 
notions remain constantly in communication with examples, or they return to them, even though they ought to have been happy to serve as springboards to reach generality, or else they illuminate thought which probes by the secret light from hidden or isolated worlds in which it irrupts. (Levinas, 1982, p. 127)

As Davis (2004, p. 95) identifies, not only examples never are "mere illustrations, since they are dynamically involved in the unending process of meaning . ..," but they may be indicative of an incessant and unstoppable economy of exchange which, in Levinas' understanding of links between the notion and the example, however, neither "occupies a stable position as illustration or truth of the other. The example is insolent and disruptive in regard to the authority of the notion." One solution Levinas proposes to such untamed status of examples is performative - in other words, to attempt a "different" type of writing, one which can be qualified as an "ethical performance" (like Otherwise than Being for Davis, 2004, p. 99); or as one which performs what the discourse discusses (cf. Critchley, 1999; Eaglestone, 1997).

The insolent and disruptive performance of the example in the form of a story or an ethical dilemma, as visible in Stoppard's Darkside, amounts to quite a few thought experiments. All these tiny narratives discuss the notion of responsibility - e.g. the death of many against the death of one; deciding whose life to save first, or the destruction of ecosystem through irresponsible and unsustainable farming practices. In the same way, they perform an unruly task towards the purpose of illustrating the seemingly insoluble and universal nature of an ethical problem because they are saturated with context, meaning and actual characters with whom Emily interacts. As an alternative to taking the stories at their face value, as it were, Emily probes the consequences of a given narrative and reveals their singularity. This leads her to recognise the abstract, detached-from-life status of the problems she is to solve:

Mr Baggot, you're supposed to be cleverer than me because you're the teacher but your games and thought experiments are stupid. In proper life people aren't just out for themselves and there's always a million things you don't know, but your stick-figures think they can work out the answers like doing a Sudoku. And what I'm thinking is, you can't work out what is the good, you just know what is the good, that's what's good about it. (Stoppard, 2013, p. 32)

While refusing to treat the example-stories as brainteasers she opts for an intuitive understanding of ethical categories; she simply responds to the characters - similarly to the way in which the Pink Floyd's roadies were responding to Roger Waters' recording session questions. What these responses have in common is their relationship with the notion of responsibility, which, as Jacques Derrida shows, involves a connection with responding to the other, for example. What is more, for the philosopher, responding is precisely connected to "answering to the other, before the other and before the law, and if possible publicly, and answering for itself, its intentions, its aims, and for the name of the agent deemed responsible" (Derrida, 1996, p. 26). In his analyses this relationship, or the "relation between responsibility and responding is not common to all languages but it does exist in Czech (odpovědniost)" (Derrida, 1996, p. 27). Interestingly, this allows for a discussion from a hauntological and undecidable perspective: 
The concept of responsibility is one of those strange concepts that give food for thought without giving themselves to thematization. It presents itself neither as a theme nor as a thesis, it gives without being seen, without presenting itself in person by means of a "fact of being seen" that can be phenomenologically intuited ... More serious still, it must always run the risk of conversion and apostasy: there is no responsibility without a dissident and inventive rupture with respect to tradition, authority, orthodoxy, rule, or doctrine. (Derrida, 1995, p. 27; my emphasis)

Responsibility is thus, in a way, subversive and entails transgression of tradition or authority. In The Gift of Death Derrida also uses an example from the biblical story of Abraham's sacrifice to illustrate the paradox of the notion in question. However, for Derrida, responsibility is about a clash between a certain notion of ethics or universality and what might be termed as "radical singularity" of "Abraham's hyper-ethical sacrifice" (1995, p. 71). The notion is considered in processual terms as a wavering between the demands of this singularity, or "wholly other form of alterity" and more general demands of more general other(s). To put it differently, a response, or responsibility, towards "any one (that is to say to any other)" is always simultaneously also "failing in my responsibilities to all others, to the ethical or political generality" (Derrida, 1995, p. 70). The paradox of responsible behaviour thus presents responsibility as an undecidable, or an aporia, which the traditionally minded "knights of good conscience" gloss over, especially if they insist upon and preach a "sense of ethical or political responsibility" (Derrida, 1995, p. 67). Instead of our singular given moment of obligation, as the philosopher points out, "[t]here are also other others, an infinite number of them, the innumerable generality of others and universal responsibility (what Kierkegaard calls the ethical order). I cannot respond to the call, the request, the obligation, or even the love of another without sacrificing the other other, the other others" (Derrida, 1995, p. 68).

In The Gift of Death, Derrida demonstrates that such aporetic understanding of responsibility is, in fact, its "most most common and everyday experience" (1995, p. 67). The radical singularity of Abraham's responsibility towards God is at the same time a moment of "sacrificing ethics," or "sacrificing what ever obliges me to also respond, in the same way, in the same instant, to all the others" (Derrida, 1995, p. 68). The human condition is thus one where ethics is a continual sacrifice; a continuous moment of decision-making between our loved ones and our professional duties or individual and general responsibilities. Derrida's understanding of responsibility towards the other thus entails an irresponsibility towards other others (cf. Anderson, 2015). However, the necessity of such continuous choice-making leaves "a remainder," a trace of the moment of undecidability which responsibility brings, which haunts our existence.

It may well be that this haunting remainder is related to the aspect which is frequently overlooked in the ethical and moral dilemmas, namely emotions. When the thought experiments are considered only in their logical dimension they simply constitute a dry exercise in reasoning, but, as Stoppard's work evidences, the emotional perspective should also be taken into consideration, even though it might "lead to widespread unemployment among moral philosophers" (Stoppard, 2013, p. 32). In other words, the play seems to 
illustrate that more important and fruitful than asking (distressing) questions such as "What is the Good?" are questions about the singularity of a given situation: the ones posed by Emily as content questions (Who was the boy who got hit by the train?) which include her meditations on the context of the narratives: "[a]nd how about them on the train? Who's to say he didn't save a serial killer? Or a mad bomber on a date with destiny?" (Stoppard, 2013, pp. 49, 9, 11). These serve to expose the abstract and, in a way, inhumane nature of the ethical exemplary narratives. Derrida makes a reference to a similar perspective when he qualifies Abraham's story as infanticide: "[ $\mathrm{t}]$ he story is no doubt monstrous, outrageous, barely conceivable: a father is ready to put to death his beloved son, his irreplaceable loved one, and that because the Other, the great Other asks him or orders him without giving the slightest explanation"; the terms used are certainly ones of emotional impact - "what could be more abominable, what mystery, could be more frightful (tremendum) vis-a-vis love, humanity, the family, or morality?" (1995, p. 67). Stoppard's Darkside seems to side with the emotional perspective on ethical and moral choices, since the main character not only interacts with the characters of the thought experiments, but in the play's narrative resolution both Emily and the (dead) Boy, who accompanies her through most of the story, are rescued by the people from the train Ethics Man had saved at the play's beginning.

Such (emotional) understanding of responsibility is not only visible in the play or Pink Floyd's record, but can partly account for the album's popularity, perhaps also indicating the reasons why Stoppard decided to rework and develop themes present already in the musical text. The positive response to the record falls onto a time identified by Eva Illouz in her Cold Intimacies (2007) as the period when the economic and the emotional domains of human life overlap. As she observes, modern individualism has not only become emotional but even dominated by economy. In turn, the economic and the political models of exchange have become models for emotional relationships, infiltrating the relationships between people, even the intimate ones. According to Illouz, while the social consequences of contemporary preoccupation with emotions testify to the mutual link between the economic and the emotional spheres, responsibility becomes linked to identifying one's position, or to

the relationship of the self to culturally situated others. When you tell me "you are late again," whether I feel shame, anger, or guilt will depend almost exclusively on my relationship to you. My boss's remark about my being late is likely to shame me, a colleague's is likely to make me angry, but if it is my child waiting for me at school, it is likely to make me feel guilty. (Illouz, 2007, p. 3)

This feeling of guilt or responsibility has become a significant element contributing to the construction of one's identity in the contemporary world. Part of this stems from the fact, recognised by Derrida, which makes us see (moral) choices as undecidable transgressions against our responsibilities to others. As we have seen in the case of Pink Floyd's Dark Side of the Moon, the pervasive feeling of guilt may take on a haunting form-indicating the spectral nature of the notion of responsibility. This, on the one hand, may be seen as the 
reason for the band's success and, on the other, as an illustration of the fact that audiences could perhaps, at some level, relate to the more individualistically driven times of the early 1970s (cf. Whiteley, 2005) but also to such recurrent understanding of responsibility.

In this respect Pink Floyd's record, reworked by Stoppard forty years later, testifies not only to the unfading popularity of the haunting music and lyrics, but also to the very haunting nature of moral choices in contemporary world. My initial aim was to look at the two texts from a hauntological perspective at the way they discuss the notion of responsibility. While the original musical material, through the use of real life recorded snippets, often thematises the negative outlook on society within ethical terms, Stoppard's play explores the notions of moral dilemmas and examples within the ethical critical discourse. In fact, following the vexed nature of the notion of responsibility — read as a certain ethical obligation-Darkside speaks about the deconstructive consequences of using example-stories which reveal the paradoxical status of ethics. Putting responsibility, as Derrida does, in the context of a subversive aporia, may lead to viewing it as an undecidable which is transgressive towards authority or tradition of an explanatory discourse. Through their structure of exemplarity, however, examples - and literature in general - can connote a threat to the integrity of philosophical discourses. The individualism of contemporary life, together with the decision making process it involves, produces ethical spectres which haunt people and force them to reconsider the responsibility for their actions. Such obligation, as Stoppard's play encourages us to see it, may become problematic due to its entanglement in the domain of the affect, usually neglected by the dry and academic ethical discourse.

\section{References}

Anderson, N. (2015). Deconstruction and ethics: An (ir)responsibility. In C. Colebrook (Ed.), Jacques Derrida: Key concepts (pp. 48-57). London, UK: Routledge.

Critchley, S. (1999). The ethics of deconstruction: Derrida and Levinas ( $2^{\text {nd }}$ ed.). Edinburgh, UK: Edinburgh University Press.

Culler, J. (2000). Literary theory: A very short introduction. Oxford, UK: Oxford University Press.

Davis, C. (2004). After poststructuralism: Reading, stories and theory. London, UK: Routledge.

Derrida, J. (1995). The gift of death. (D. Willis, Trans.). Chicago, IL: The University of Chicago Press.

Eaglestone, R. (1997). Ethical criticism: Reading after Levinas. Edinburgh, UK: Edinburgh University Press.

van Elferen, I. (2012). Gothic music: The sounds of the uncanny. Cardiff, UK: University of Wales Press.

Harpham, G. G. (1994). Ethics. In F. Lentricchia \& T. McLaughlin (Eds.), Critical terms for literary study ( $2^{\text {nd }}$ ed.) (pp. 387-405). Chicago, IL: University of Chicago Press.

Illouz, E. (2007). Cold intimacies: The making of emotional capitalism. Cambridge, UK: Polity Press. 
Levinas, E. (1982). L'Au-delà du verset: Lectures et discours talmudiques. Paris, France: Minuit.

Pink Floyd. (2011). Dark Side of the Moon [CD]. USA: Capitol Records. (Original record 1973)

Ricoeur, P. (2000). The concept of responsibility: An essay in semantic analysis. In P. Ricoeur, The just (pp. 11-35). (D. Pellauer, Trans.). Chicago, IL: University of Chicago Press.

Stoppard, T. (2013). Darkside. London, UK: Faber and Faber.

Weinstein, D. (2002). Progressive rock as text: The lyrics of Roger Waters. In K. Holm-Hudson (Ed.), Progressive rock reconsidered (pp. 91-110). London, UK: Routledge.

Whiteley, S. (2005). Pink Floyd: Dark Side of the Moon. In S. Whiteley, The space between the notes: Rock and the counter-culture (pp. 103-118). London, UK: Routledge. 

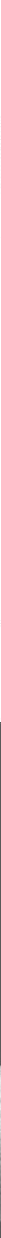
Anna Kola, Untitled, digital print, 49x100 cm, 2010 Hand $\boldsymbol{I I I}>\boldsymbol{I} \boldsymbol{V}$, photograph, $35 \times 100 \mathrm{~cm}, 2007$

Hand $\boldsymbol{V}>\boldsymbol{V I}$, photograph, 35x100 cm, 2007 
Part Four: Ghostly Legacies 



\title{
Haunting across the Class Divide: Sarah Waters's Affinity and The Little Stranger
}

\author{
Barbara Klonowska \\ Catholic University of Lublin \\ barbara.klonowska@kul.pl \\ Received 28 February 2017; accepted 3 October 2017.
}

\begin{abstract}
Haunting in literary fiction is often interpreted psychologically as a sign of suppressed psychic content or as nostalgia or mourning for the loss. Yet, it may also be used allegorically as a manifestation of hidden social conflicts, and hence mark a political agenda of thus constructed works. In the novels by Sarah Waters spectres, poltergeists and haunting appear not as a sign of or a contact with an outer reality; to the contrary, they may be seen as perfectly human - though eccentric - expressions of class and economic inferiority. In Affinity spectres and spiritual séances are presented as a means of earning money by lower classes and the latter's cunning use of the upper classes' credulity. In The Little Stranger the poltergeist may be interpreted as an accumulated anger and desire of the servants long ignored by the masters of the emblematic country house. In both, haunting and ghosts manifest vengeance of the underprivileged taken on the socially superior. The essay shows how fictional haunting and spectrality, far from marking a supernatural reality or introducing extrasensory concepts, may function as an allegorical method to discuss political and social problems such as class inequality or social justice.
\end{abstract}

Keywords: haunting; neo-Victorian fiction; class; trauma; suppression; rewriting; political intervention.

\section{Haunting Literature}

In literary texts, the theme of haunting and figures of spectres or ghosts may simultaneously perform several functions. For one, they often appear purely for entertainment purposes, introducing attractive plots and intriguing characters, as in popular ghost stories or in the literature for younger readers, where spectrality often brings little more than suspense and fun. More importantly, however, through drawing attention to supernatural phenomena, literary spectres, ghosts and haunting may lead to the resulting revising and 
expanding of the concept of reality installed by existing philosophical and political systems and shared by the reading public — as is the case, for instance, of magic realist fiction which thus challenges and problematises the received notions of reality, time, space or history. Finally, haunting may also suggest problems suppressed by official discourses, be it private or public, which yet resurface in a spectral form to mark the trace of that which has been silenced and eliminated - as in, for instance, Gothic literature which strongly emphasises culturally suppressed and unwanted notions. In the latter case, spectrality and haunting may be and are often interpreted psychologically, as a literary strategy to mark the processes of suppression and the subsequent return of variously unwanted psychological content. Sexuality, trauma or loss feature prominently in spectral literature, with haunting signalling the return to that which has been suppressed, unrealised, lost or too painful to confront openly. This return, as psychoanalysts suggest, may perform several functions, which range from coming to terms and confrontation with painful experience, through mourning, nostalgia and remembering, to restorative processes. The obsessive return is usually linked by psychologists to trauma and seen as an attempt to work through it via incessant repetition; for Sigmund Freud, as Ankhi Mukherjee suggests, "repetition is a mode of recuperating loss, a ritual of control" (Mukherjee, 2005, p. 109). Spectrality, then, may be seen as an empowering strategy of confronting and dealing with harm and loss. In contrast, the Lacanian interpretation of the compulsive return sees it as "a quest for lost pleasure through symbolic substitution" (Mukherjee, 2005, p. 109) and a symptom of alienation rather than mastery. In both cases, however, trauma and pleasure, control and alienation, seem to mark the extreme poles, with the broad spectrum of possible forms and functions of haunting that lie in between.

One of the relatively less popular and less frequently explored possibilities of interpreting haunting and spectres is to see them as sociological phenomena and social facts, marking and signalling social and political rather than purely psychological phenomena. Yet, as Avery F. Gordon remarks, "haunting is a constituent element of modern social life. It is neither pre-modern superstition nor individual psychosis; it is a generalizable social phenomenon of great import" (1997, p. 7). Thus, apart from its aesthetic, literary or psychological functions, haunting may be also interpreted as a sign or a trace marking social phenomena, and processes operating at a larger scale than the individual psyche. Gordon claims that

the ghost is just the sign, or the empirical evidence. . . that tells you a haunting is taking place; the ghost is not simply a dead or a missing person, but a social figure, and investigating it can lead to that dense site where history and subjectivity make social life. $(1997$, p. 8)

Haunting, then, may be studied as a sociological phenomenon worth analysing on its own terms; yet, it may also be treated as a sign of latent social problems and thus interesting as a mode of investigation leading to the knowledge about the haunted communities and their histories. 
Thus, the literature employing the themes and motifs of haunting or ghostly and spectral figures may be variously analysed for its very diverse aesthetic, psychological or social functions. Haunting and spectrality seem to be employed by contemporary culture to signal a plethora of phenomena and thus may become subjects of numerous subsequent interpretations. The contemporary novel is one of these areas of culture where spectrality seems to be operating vigorously, despite the lasting high reputation of realism or the seeming reluctance of the high-brow novel to treat seriously phenomena that are often classified as parapsychology or superstition. The recent novels by Sarah Waters may serve as an excellent example of an ingenious employment of the theme of haunting, which is used as a vehicle to tackle rather serious and large social problems. This essay will analyse two of her novels, Affinity (1999) and The Little Stranger (2009), to argue that in Waters's fiction, haunting and spectrality appear both as manifestations of suppressed emotions, and as a trace of powerful social conflicts. Haunting, then, on the one hand, for the characters of the novels, functions as a psychological strategy and a method to gratify their particular desires and achieve their secret aims. On the other hand, read from a broader sociological point of view, haunting becomes a spectacular sign of seemingly unseen and yet long-lasting and vigorously operating processes of social hierarchization, and a means of subsequent retribution exacted by the helpless and mistreated. As the subsequent analysis will suggest, Waters's novels construct haunting both negatively, as a sign and trace of social injustice, and positively, as a perverted yet surprisingly effective way of taking revenge on the perpetrators and compensating for the harm done. In so doing, Waters's fiction demonstrates that literary haunting may prove both an aesthetically attractive and politically effective way of returning to the painful social problems undertaken to examine and possibly correct the wrongs of the past.

\section{Haunting as a Ploy}

Both of Waters's novels may be easily classified generically as historical novels since they amply fulfil the criteria enumerated by Avrom Fleishman in his definition of the genre of the historical novel: the distance from the past exceeding that of two generations, the inclusion of recognised historical figures, a plot referring to historical events, particularly those in the public sphere (e.g. wars), specificity and realistic descriptions, the suggestive "feeling" of the times described, a meaning and value, all combined with the literary entourage of genres such as tragedy, comedy, romance and satire (Fleishman, 1971, pp. 3-8). Both Affinity and The Little Stranger, however, treat the traditional structure of the historical novel, on the one hand, as a starting point of the investigation of the past, and on the other, as a means to return to it in a gesture of an imaginary compensation and reparation.

Affinity is a queer romance set in mid-Victorian times, involving ostensibly a middle-class spinster, Margaret Prior, shown as gradually falling in love with and discovering her "affinity" to Selina Dawes, a working-class spirit-medium serving her term in the Millbank prison for women, sentenced for the assault leading to death during a spiritist séance. In the background of this plot, however, another romance is signalled and developed, which in the end turns out much more dramatically vital: that of Selina and her servant-companion, 
Ruth Vigers. Their relationship constitutes the core of the story, and yet, characteristically, it goes unnoticed both by Margaret-the narrator, and by the represented Victorian milieu. This narratorial invisibility and the seemingly small — though, in fact, fundamental - dramatic importance of the romance between a servant and a spirit-medium may be interpreted as reflecting in the plot of the text the social "invisibility" and marginal importance of lower-class figures and their lives. In her diary, the main narrator of the story, Margaret, describes her growing "affinity"; her narratorial point of view is that of an educated and over-sensitive young lady of means, interested in art and science and used to ignoring servants, together with other practicalities of mundane life. Thus, her credulity and blindness, which lead to the dramatic ending of the novel when she discovers the extent of her naivety and her role of the dupe in a deception plot, result only partly from the specific character construction. More broadly, her blindness may be also read as a convenient metonymy of a larger blindness of the privileged and of the social invisibility of lower classes.

The characters representing the lower classes, however, turn out equally important in the plot of the novel as the privileged ones, and haunting and spectres literally become their means of survival. Selina Dawes successfully earns a living as a spirit-medium that gratifies the desires of bereft ladies, hysterical young women and curious gentlemen. With the help of her accomplice, Ruth Vigers, she effectively deceives her clients during séances, gaining the reputation of a gifted medium, which brings financial security and the chance to enjoy the middle-class lifestyle. After her downfall, she resorts to fake haunting again as a method of escaping from prison and fleeing England together with her lover-accomplice. As Susan Alice Fischer observes, "while Margaret has been given more voice and narrative space, the novel ending with Selina's subversive liberation leaves another 'sister' in the darkness of death and opens the reader's eyes to a desperate resistance to a system rooted in class hierarchy" $(2013$, p. 28).

Thus, far from marking any supernatural reality or hinting at the spiritual or psychological, haunting in this novel functions, first, at a purely literal level as an occupation available to lower-class girls, allowing them to make ends meet and - perhaps less typically — get out of prison. Working as a medium-spirit, though seemingly eccentric, was in fact not an uncommon female profession in Victorian England. In her study of neo-Victorian fiction Louisa Hadley observes that most of the registered mediums of this era were women and, following the ground-breaking work by Alex Owen, she shows how, though not unproblematically, "nineteenth-century spiritualism challenged Victorian gender ideologies by granting women power within the spiritual world" (2010, p. 91). Although, as Alex Owen demonstrates, female spiritualism was in fact quite complicit with the Victorian ideals and concepts of femininity, it nevertheless granted women some freedom and a possibility to improve their limited position within the society of that time (Hadley, 2010, p. 87). Haunting, then, though faked, is performed for very pragmatic reasons within Waters's novel: for its characters, it provides a job, a status-improvement, and liberation. The narrative, in turn, employs it not so much to point to the supernatural or psychological; rather, it refers the reader to the social and political, inviting them to consider the position of women in general, and lower-class women in particular. 
Interestingly, however, and in keeping with the frequent interpretation of textual haunting as a sign of repression, in Affinity haunting does, albeit perversely, perform that function, too. It seems to refer the reader back to the repressed or inferior sex (women), class (working class) and sexual orientation (lesbians) and imaginatively not only to present but also to improve their fate. Thus, haunting, although doubly fictional in this novel, does manage to bring back the experience - though not the point of view — of lower class lesbian women and within the narrative, allows them to enjoy a better fate and justice than it was the case in reality. In Waters's novel, then, haunting functions politically as a recuperation of and an imaginary intervention into the past in order to correct its wrongdoings. In this, as Hadley observes, "Waters adopts a Marxist perspective by drawing attention to the position of the lower classes" (2010, p. 89). Textual haunting, used as a ploy by the characters and as a means to improve their social and financial position, at the level of the narrative works to improve, if only imaginatively, the position of lower-class women in the discourses about the past. It offers them - though only textually — an opportunity to present and correct their historical experience.

\section{Haunting as Vengeance}

Yet, both in Affinity and, to a significantly greater extent, in The Little Stranger, haunting may be interpreted not merely sociologically, as a narrative tool to present some social experience, but also psychologically, as a way to convey and express emotions. In the former novel, haunting recuperates the anger of the characters of Ruth Vigers and Selina Dawes and serves as a way to take revenge for years of their social inferiority and neglect. In the latter novel, this is also the case of the character of a working-class physician, Dr Faraday, a seemingly benevolent and well-wishing neighbour of a country-house family who, through subconsciously provoked haunting and visitations, takes revenge for his inferiority on those who for years despised and ignored him and his family. As Emma Parker observes in her insightful and inspiring reading of haunting in this novel, "by presenting . . . a house haunted by a spirit fuelled by envy and anger, The Little Stranger explores the destructive effects of class hierarchy, while also challenging dominant ideologies of gender and sexuality" (2013, p. 112). Thus, the textual haunting functions also as a convenient vehicle for personal anger and an effective way to return to and correct the events perceived as traumatic and wrong.

Faraday is the first-person narrator of the novel and his point of view shapes the narrative and the information it provides. Well-mannered, rational and nice, Faraday, however, gradually reveals some of his darker emotions: anger and bitterness connected with his lower social position, disappointment with his life spent on hard work, the feeling of failure of his dreams, and the occasional hatred and envy of his neighbours. Perfectly natural and motivated, these emotions look mild enough and do not seem to influence the behaviour of the character and the plot of the novel; again, it is only gradually and indirectly that the link to the events of haunting and their disastrous effects become revealed. The growing sympathy and closeness of Faraday to the impoverished Ayreses and their once splendid residence, 
Hundreds Hall, is systematically accompanied by the disasters striking the family and the house. Starting with the accident with the dog Gyp biting a little girl and being put to death as a result; through the fire and the subsequent commitment to a psychiatric institution of the young master of the house, Roderick Ayres; to the suicide of Lady Ayres unable to mourn and live through the death of her baby-daughter; and ending with the surprising death or suicide of the last of the Ayreses, Caroline - all these events mark the development of and become milestones in the relationship between Dr Faraday and the Ayreses.

Interestingly, the dramatic visitations of the house and their disastrous results usually succeed episodes particularly unpleasant for Faraday: his feeling of being a second-class acquaintance during the party, his anger at Roderick's insults during the official dinner, or the rejection of his advances by Caroline. The fictional Faraday is constructed as a character too polite to express his anger and outrage openly; instead, his accumulated and suppressed hatred resurfaces within the narrative as a lethal energy which, through haunting and ghosts, wreaks havoc within the Ayreses house. Faraday's muted fury is aimed at the family which has been humiliating him and his family for a long time, but also at the house itself which embodies everything he has ever aspired to: class, sophistication, beauty and status, and which has been denied to him. His frustration with the house, his ambivalent feelings of admiration and the wish to destroy are in fact manifested quite early within the narrative, in a scene of his childish vandalisation of one of the house's ornaments. The gesture of chipping off a fragment of an ornament perfectly encapsulates, on the one hand, the admiration and wish to possess, and the anger at being rejected, on the other. Faraday's subsequent attitude towards the house is an extension and intensification of this childish ambivalence. Construed as an object of desire, the house provokes contradictory emotions explainable psychologically as a wish to unite with the desired object, and a simultaneous hatred towards it resulting from helplessness and dependence. The unresolved conflict and the ungratified desire find expression in the narrative haunting and both the destruction of and the unification with the house that it brings. The last scene of the novel vividly shows this ambivalent combination, with Faraday taking possession of the already empty house and thus commenting on its condition and his own feelings:

Wandering softly through the twilit spaces, I can even seem to see the house as its architect must have done when it was new, with its plaster detail fresh and unchipped, its surfaces unblemished. In those moments there is no trace of the Ayreses at all. It is as if the house has thrown the family off, like springing turf throwing off a footprint. . . If Hundreds Hall is haunted, however, its ghost doesn't show itself to me. For I'll turn, and am disappointedrealising that what I'm looking at is only a cracked window-pane, and that the face gazing distortedly from it, baffled and longing, is my own. (Waters, 2009, pp. 498-499)

Union and destruction, hatred, the wish to annihilate and admiration are intertwined within the character, dramatised by the plot of the novel as haunting, and embodied in the architectural space of the house. Haunting, then, becomes a fictional dramatisation of the complexities of desire and the anger whose roots lie in social inferiority and the frustrated wish to possess status and dignity. The negative energy of these feelings accumulates and becomes separated from the character, taking a fictional life of its own and emerging as 
haunting ghosts. Within the novel, they are referred to as poltergeists and described by one of the characters as "some sort of energy, or a collection of energies. . . They're not ghosts. They're parts of a person. Unconscious parts, so strong and troubled they can take on a life of their own" (Waters, 2009, p. 364). The fictional poltergeist in The Little Stranger, separated from its source, takes on the mission of exacting revenge for social injustice and gratifying the character's long-harboured desires. The social combines with the personal and explodes in a series of disastrous visitations that effectively wipe out the sources of both psychological and social discomfort.

Thus interpreted, haunting in Waters's novel may illustrate not merely the sociological, but also the psychological reading of spectrality as a textual expression and revisitation of a suppressed psychological - usually traumatic - content. The Little Stranger, even to a stronger degree than Affinity, captures the ambivalent, socio-psychological function of haunting and dramatises textually both the more general social ramifications of the position of lower classes, and their very real and palpable psychological consequences.

\section{Haunting as Political Intervention}

In both novels, then, haunting and spiritualism function at a number of levels. Aesthetically, they provide the narratives with interesting and attractive stories, plot twists and events that usually win the sympathy of readers. They introduce aspects relatively little known (e.g. the nineteenth-century female spiritualism) and offer a different perspective on the past (e.g. the post-war welfare state). More importantly, though, psychologically, they point to suppressed negative emotions of characters resulting from long-silenced traumas and serve as an expression of their anger and frustration. Finally, since at the root of the latter feelings lies the sense of social injustice caused by the British class structure and resistance to the resulting sense of inferiority, fictional haunting brings social and political matters to the fore, becoming a means to revisit and come to terms with the difficult and inglorious past.

Both novels show - via haunting - the revenge and retribution of the working class, exacted on the middle classes and aristocrats, for centuries of mistreatment, loathing and deprivation. Thus, Waters's novels become a clearly defined voice in the discussion of the past, revisiting it critically rather than nostalgically in a sharp contrast, for instance, to the tradition of the country-house novel. As Urszula Terentowicz-Fotyga observes, the English country house tends to be often represented — especially in the novel of manners which "defines the country house as 'a carrier of culture,' [and] a 'great good place"' (2015, p. 173) as a locus of specifically grand and noble ideals and values and a haven of "Englishness." Such portrayal tends to conveniently neglect the darker and less noble facts connected with the maintenance and success of such houses: the exploitation and mistreatment of the lower-class servants who operated them and who were treated with loathing and indifference. Waters's novels, in contrast, focus on the human costs involved in such projects and present and give voice to the so far little celebrated actors and experiences. 
Moreover, both novels, apart from showing the experience, attempt to imaginatively correct the wrongdoings of the past by presenting justice as it might have been dreamt of by the working classes. The texts offer them an opportunity - imaginary though it is - of exacting the revenge and setting the record straight. Haunting as a literary theme seems to be a convenient fictional vehicle for these goals, and, though somewhat surprisingly combined with political purposes, serves as a perfect tool to show the retribution of the underprivileged. Fictional spectres take on a political role of intervening into the discourses of the past and, via the imaginative correction they introduce, of changing the political status quo.

\section{References}

Fischer, S. A. (2013). 'Taking back the night'? Feminism in Sarah Waters' Affinity and Virginia Woolf's Night and Day. In K. Mitchell (Ed.), Sarah Waters: Contemporary critical perspectives (pp. 16-28). London: Bloomsbury.

Fleishman, A. (1971). The English historical novel: Walter Scott to Virginia Woolf. Baltimore, MD: Johns Hopkins University Press.

Gordon, A. F. (1997). Ghostly matters: Haunting and the sociological imagination. Minneapolis: University of Minnesota Press.

Hadley, L. (2010). Neo-Victorian fiction and historical narrative: The Victorians and us. Houndmills, UK: Palgrave.

Mukherjee, A. (2005). Missed encounters: Repetition, rewriting, and contemporary returns to Charles Dickens's Great Expectations. Contemporary Literature, 46(1), 108-133.

Owen, A. (1989). The darkened room: Women, power and spiritualism in late Victorian England. London, UK: Virago.

Parker, E. (2013). The country house revisited: Sarah Waters' The Little Stranger. In K. Mitchell (Ed.), Sarah Waters: Contemporary critical perspectives (pp. 99-113). London, UK: Bloomsbury.

Terentowicz-Fotyga, U. (2015). Competing genres in the English country house: The Little Stranger by Sarah Waters. In A. Kędra-Kardela \& A. Kowalczyk (Eds.), Expanding the Gothic canon: Studies in literature, film and new media (pp. 173-192). Frankfurt am Mein, Germany: Peter Lang.

Waters, S. (1999). Affinity. London, UK: Virago.

Waters, S. (2009). The little stranger. London, UK: Virago. 


\title{
Spectral Economies in Graham Swift's Mothering Sunday: A Romance
}

\author{
Katarzyna Więckowska \\ Nicolaus Copernicus University in Toruń \\ klew@umk.pl \\ Received 6 August 2017; accepted 30 October 2017.
}

\begin{abstract}
This article employs the concepts of spectres and haunting to analyse Graham Swift's Mothering Sunday: A Romance (2016) as a commentary on (literary) history and its economy of spectres. Referring to Jacques Derrida's notions of haunting, inheritance, and time, I focus on the spectres of literary modernism and the First World War to explore the ways in which Swift's novella questions the canonical representation of modernism and revises the conventional means of writing about the past, memory, and history. The analysis of Mothering Sunday approaches the spectre as a figure of repressed otherness and a reminder of what has been excluded or silenced, so as to trace some of the ghosts that appear in the book and to underline its melancholic, spectral character. Situating Swift's novella within the context of contemporary cultural criticism, I propose to see it as a sign of a larger cultural and critical turn, where spectres have been assimilated into the structure of the everyday and where the experience of haunting has become a major expression of the present condition.
\end{abstract}

Keywords: haunting; spectres; modernism; Graham Swift; women; WWI; textuality.

What does it mean to follow a ghost? And what if this came down to being followed by it, always, persecuted perhaps by the very chase we are leading? Here again what seems to be out front, the future, comes back in advance: from the past, from the back. (Derrida, 1994, p. 10)

All the scenes. All the scenes that never occur, but wait in the wings of possibility. (Swift, 2016, p. 54)

In Specters of Marx, Jacques Derrida describes the ghost as primarily a figure of disruption whose appearance transforms the established notions of time, space, knowledge, and identity, and opens them up for a radical re-definition. The spectre is neither present 
nor absent - neither here and now, nor safely there in the past - and it blurs the distinctions between the private and the public, or the social and the individual. On a most general level, haunting is bound up with uncertainty and doubt, leading to a transformation of ways of knowing and modes of perception, and to a re-cognition of the importance of something other than the already known. The spectre introduces indeterminacy, aptly captured by the uncertainty as to whether one follows or is followed by a ghost (Derrida, 1994, p. 10), and it brings in a confusion that makes it impossible to demarcate or stabilize all types of borders, including those between object and subject, or between self and other. Haunting always takes place in the spaces in-between, "at borders, between all those 'ones' and 'others' - alive and dead, present and absent, there and not there, visible and invisible" (Wolfreys, 2010, p. 16), and it always invokes a certain outside (Blanco \& Peeren, 2013, p. 9), pointing to what has been excluded or silenced and calling forth what appears to be absent. In doing so, it destabilizes the known as well as those who know, effectively unmasking their "essential unknowing" (Davis, 2005, p. 377); when introduced - as Derrida insists it should be- - "into the very conception of a concept. Of every concept, beginning with the concepts of being and time" (Derrida, 1994, p. 161), haunting serves to underline the uncertainty and provisionality, the ultimate undecidability of any and all concepts. ${ }^{1}$

Within the spaces where spectres may appear, literature occupies a very specific place since it is both haunted - by other texts, thoughts, and histories - and haunting, through the effects it may produce on readers and other texts. In a sense, as Julian Wolfreys claims, "to tell a story is always to invoke ghosts, to open a space through which something other returns" (Wolfreys, 2002, p. 3), where the other may signify other thoughts, perceptions, states of mind, emotions, or bodies. ${ }^{2}$ One could argue, following Avery F. Gordon, that this "spectral" character of fiction is particularly visible in texts dealing with histories that have been omitted or silenced, so that " $[\mathrm{t}] \mathrm{o}$ write stories concerning exclusions and invisibilities" comes to mean, in a very literal sense, "to write ghost stories" (Gordon, 2004, p. 115). Accordingly, narratives that give voice to the silenced, or that point to the times and places that have been silenced, necessitate a re-thinking of other texts and the ways in which they have been treated and read, perhaps especially when such narratives deal with (literary) history and when they frame their stories by evoking the ghosts of other texts.

In this article, I approach Graham Swift's Mothering Sunday: A Romance (2016) as a "ghost story" which, in a manner similar to that described by Gordon, focuses on exclusions and invisibilities and conjures up an entire structure of ghosts, including textual ones, in order to comment on some important omissions and silences in modern (literary) history. Discussing some of the ghosts that appear in the novella, I focus in particular on the spectres

\footnotetext{
${ }^{1}$ For a discussion of hauntology, the spectral turn, and cognition, see "Hauntology and Cognition: Questions of Knowledge, Pasts and Futures” (2017) by Edyta Lorek-Jezińska and Katarzyna Więckowska.

${ }^{2}$ I draw here on Wolfreys's statement that fiction "becomes haunted by the work of thought and perception, turned simultaneously towards representation of another's state of mind on the one hand, and, on the other, towards the very interiority of the reader's imaginative projection" (Wolfreys, 2010, p. 10).
} 
of literary modernism and the Great War, and on the woman writer whose life story conjures them up. I read Swift's book as a commentary on literary history and its economy of spectres, and as an exploration of ways of writing about history that value the emotional and the subjective over the objective and the factual. Finally, I place Swift's portrayal of literary modernism within the context of critical accounts of contemporary culture which, in a rather uncanny manner, return to modernism to describe the present as spectral, revisited by a number of (modernist) ghosts.

Told from the perspective of a ninety-eight-year-old woman writer, Mothering Sunday offers a series of short vignettes of the $20^{\text {th }}$ century to explore the connections between private stories and public histories, and to examine the work of memory, highlighting its selective and fundamentally subjective character. The journey into Jane Fairchild's past and the moments that have formed her as a writer is marked by repetition, in particular by the returns to Mothering Sunday of $30^{\text {th }}$ March 1924, a day filled by love, loss, and books. ${ }^{3}$ In effect, the text becomes an act of prolonged remembering which lingers on moments from the past and dwells on "the scenes that never occur, but wait in the wings of possibility" (Swift, 2016 , p. 54) to become haunting reminders of unrealized potentials and different futures. Significantly, while the memories of past events and of people and places that are long gone appear in the text as spectres, these are spectres coming from a past that is already haunted by its own ghosts, as signalled by the beginning of the book, which recalls a particular day in the past and situates it against a more distant, already receding past: "Once upon a time, before the boys were killed and when there were more horses than cars, before the male servant disappeared and they made do, at Upleigh and at Beechwood, with just a cook and a maid" (p. 3). By juxtaposing the story of a woman writer against the image of public and private histories as always already driven by spectres, the book hints at its own spectral economy, signalling both the procedures of sequestering some ghosts and uncovering others, and the inevitable repetition of similar strategies in individual acts of reading.

Mothering Sunday is a Künstlerroman that recounts the life of Jane Fairchild, an acclaimed writer, who at the close of the $20^{\text {th }}$ century recalls the experiences that have turned her into an artist: her birth; a secret rendezvous with her lover on Mothering Sunday of March $30^{\text {th }}$ 1924; and her life in Oxford, where she moved in October 1924 to work as an assistant in a bookshop and where she was given her first typewriter. Out of these, Jane singles out the Sunday in March 1924 as the key moment in her transformation, the point "when she really became a writer, or had the seed of it truly planted in her" (Swift, 2016, p. 87). On this day, Paul - the heir to the Sheringhams' fortune, to be married in two weeks' time to Miss Emma Carrington Hobday, a woman of his own class - invites Jane, a maid from the neighbouring Beechwood household, to his family house, Upleigh. The invitation marks a change in their seven-year-long secret relationship and constitutes an act of transgression which violates the existing class divisions by, for example, letting the servant enter the

\footnotetext{
${ }^{3}$ The sentimental expressions bordering on kitsch illustrate the increasing importance of sentimantality and the sentimental in Swift's work, which has been revealingly discussed by Jakob Winnberg in An Aesthetics of Vulnerability: The Sentimentum and the Novels of Graham Swift (2003).
} 
house through the front door. The sense of transgressing rules is reinforced when, after their love-making, Jane is left alone in Upleigh and wanders through the house "naked, you might say, as on the day she was born" (p. 87), metaphorically taking possession of the objects placed therein and the social status they signify. Decades later, she describes the visit as a birth-like experience that made her realise "what it truly means to be put down in this world, placed, so to speak, on its extraordinary doorstep" (p. 87). The feeling of exhilaration and of something new opening before her is terminated when she returns to Beechwood and is informed by its owner, Mr Niven, that Paul has been killed in what he and others consider a car accident, but what Jane knows must have been a suicide.

As a Bildungsroman, Mothering Sunday foregrounds the relationship between the individual and the society, so that, as Steven Connor states describing this type of fiction, "society becomes visible as the enabling field of operations for the individual, and the individual as the actualisation of social possibility" (as cited in Ferrebe, 2005, p. 70). ${ }^{4}$ Accordingly, the story of Jane and Paul and their romance illustrates the ways in which personal histories are embedded within the larger social narrative, highlighting both the restrictions that the society imposes on individual development and the opening of new social possibilities. Paul's suicide and Jane's "birth" as a writer reflect a world in transition, with the two representing the dying of the old order and the emergence of the new, respectively. The sense of passing and of impending change is indicated in the title of the book, Mothering Sunday, which refers to the old custom of giving servants a day off to visit their mothers, ${ }^{5}$ and which is described in the novella as "a ritual already fading" (Swift, 2016, p. 13), whose "very reason for existing" would soon become "a historical oddity, the custom of another age" (p. 27). This aura of a receding world is sustained through Paul's attitude to his parents, whom he calls "the shower," thereby indicating their obsolescence and loss of significance, as well as through the obstinacy with which the Sheringhams and their friends continue to cling to old customs for the sake of "the same sad, wishing-the-pastback reasons" (p. 13). Most importantly, the world of 1920s Berkshire is, as Jane acknowledges, a world "in mourning" (p. 21), whose inhabitants are unable to put the past to rest and to come to terms with the losses of the Great War.

World War I has been described by numerous commentators as the first major modern crisis that radically transformed the society and culture, and that continues to influence the world up to today, obstinately refusing "to remain buried in the past" (Stevenson, 2013, p. vii). Samuel Hynes has summarised the overall effect of the war as a transformation of "the ways in which men and women thought not only about war but about the world, and about culture and its expressions" (1990, p. ix), and Randall Stevenson has argued that the war

\footnotetext{
${ }^{4}$ The choice of Bildungsroman highlights another link between literature and WWI: according to Stevenson, the senselessness of the war and the uncertainty of survival not only discouraged writers from using the Bildungsroman, but also led to its inversion into narratives following "a kind of unbildungs - an education leading not to satisfactory stability, but towards disillusion and disaster" (Stevenson, 2013, p. 75).

${ }^{5}$ Mothering Sunday has also religious connotations, as it refers to the custom of visiting one's "mother church" on the fourth Sunday in Lent.
} 
fundamentally changed the modern way of thinking, "terminating faiths in progress, modernity, and rational systems of thought which had been sustained ever since the Enlightenment in the eighteenth century" (2013, p. viii). Significantly, the war is almost unanimously seen as the event that undermined the belief in "an evolving, coherent history" (Stevenson, 2013, p. 191), replacing it by "a conception of history as discontinuous, fragmented, and subjective" (Hynes, 1990, p. 433), as continually haunted by spectres from the past that may rupture or halt its movement.

Swift's novella records the sense of a break in history and the ensuing precariousness by evoking numerous ghosts of the First World War, so that they might be seen as forming the textual core of other spectral structures that appear in the book. The local community is depicted as decimated by the war: the Nivens, for whom Jane works, have lost in the war their two sons, Philip and James, and two of the Sheringhams' boys, Dick and Freddy, were killed in France. Years after the war, in 1924, the dead boys' rooms at Beechwood are preserved as "unalterable shrines" (Swift, 2016, p. 63) where everything remains "just as it was" (p. 92), as if their owners were to return any moment, and both the Nivens and the Sheringhams keep their boys' books waiting for them in special sections of their libraries, even though the war utterly destroyed the heroic ideal of manly adventure which the novels propagate and which Paul, the survivor, describes as "the tommyrot" (p. 71). The countryside itself is filled by all-pervasive "accumulated loss and grief" (p. 92) and by ghost-like figures, so that Jane and her friend Milly the cook, allowed by Mr Niven to ride his dead sons' bicycles, become merely "the dim ghosts of Philip and James" (p. 14). Rather disturbingly, the photographs of Paul's brothers, Dick and Freddy, watch the living from their fixed position "on the dressing table in silver frames" (p. 41); they are the silent witnesses of Jane and Paul's lovemaking, and their vacant looks follow the girl as she walks naked through the house that once belonged to them (pp. 41, 56). Because Paul is the only boy left - the last of the boys - and the inheritor of what he calls "loot" (p. 3), he is to guarantee the continuity of history by providing a link with the past as the surviving brother and friend of the lost boys, and by preserving the old way of life through his future marriage with Emma Hobday. Thus, Paul's death is a blatant demonstration of the end of the old social structures and cultural patterns, and a symptom of the loss of faith in a continuous and coherent history.

Mothering Sunday foregrounds the de-realised, spectral quality of the post-war world and follows the widespread depiction of the period as "the apocalyptic moment of transition into the new" and a time of anxious uncertainty (Bradbury \& McFarlane, 1976, pp. 51, 48). The new is represented through Jane, the "orphan, maid, prostitute" (Swift, 2016, p. 20), who "would become writer . . ., would write nineteen novels . . ., would even become a 'modern writer"' (p. 130). Jane's becoming a writer is linked with the developing modernity and the changes taking place in the 1920s, including the rise of the New 
Woman and the possibilities opening before women ${ }^{6}$; it also constitutes a major act of transgression of class and gender divisions that is linked to the death of the boys, whose books Jane is allowed to read once she becomes a maid in Beechwood. These books are "[b]oys' stuff, adventure stuff" about "[p]irates and kings-in-armour, buried treasure and sailing ships" (p. 69) by writers such as H. Rider Haggard, R. L. Stevenson, R. M. Ballantyne, or G. A. Henty; they all hark "back to childhood, boyhood or gathering manhood" (p. 66), endlessly recycling the image of manly muscular Christians that was prevalent at the turn of the century and that was discredited during the war. ${ }^{7}$ In all these tales, Jane decodes the "submerged message" or "subtext" that "life itself might be an adventure" (p. 79), but also that "adventure" is a "boys' thing" that necessarily involves "going to sea - a voyage, an unknown land - as if that was the essence of adventure and what every boy wanted to do" (p. 125). Thus, reading boys' books becomes an act of transgression and re-appropriation that makes Jane, rather than Paul, the inheritor of the "loot" ; it is this that sets her on the route to become a writer and gives a different meaning to the words that she "borrows" from the opening of Stevenson's Kidnapped to start her own story: "I will begin the story of my adventures..." (pp. 71, 79).

While transgression is a key concept in the way class and gender divisions are depicted in Mothering Sunday, it is not presented as an act of rapid change, but rather as an ongoing and long-lasting process of transforming and re-writing the existing rules from within. The sense of gradual change is contained in the second part of the title, A Romance, which draws attention to the various meanings of the word and introduces an element of play with generic conventions and their gendered (and gendering) history. Mothering Sunday is explicitly a romance, as it deals with a love affair across the class divide which, according to the formula of the popular genre, should have a happy ending; indeed, during their Sunday tryst, Jane does consider the possibility that the invitation to Paul's family house may suggest that he will not marry Emma. Additionally, the chance of a happy ending is reinforced by the epigraph to the book, "You shall go to the ball!", which casts Jane as a modern Cinderella, and in the references to Snow White and the Seven Dwarfs that are

\footnotetext{
${ }^{6}$ That the possibilities are still rather limited is explicit in Jane's description of her stay in Oxford: "If she couldn't have 'gone to Oxford' in the other sense, then she became intimate with those who had. It might even be said that she moved in university 'circles' more freely and successfully than many-poor swots that they were - who were actually there. She could even pass herself off quite convincingly as that rare and frightening creature, a female undergraduate" (Swift, 2016, p. 100; emphasis in original).

${ }^{7}$ For a discussion of muscular Christianity and heroic manhood, see K. Więckowska's Spectres of Men: Masculinity, Crisis and British Literature (2014), especially pp. 121-132.

${ }^{8}$ In this respect, I disagree with critics who see in the fact that Jane reads boys' books a proof of Swift's failure to move beyond the "traditional" female protagonist. This is the stance taken by Donald Kaczvinsky, who writes that, "While Jane Fairchild is a strong, independent, and sympathetic woman who rises to the top of her profession, she finds her voice as a writer by reading boys' adventure stories and the tales of Joseph Conrad" (2016, p. 85). From my perspective, the fact that Jane educates herself on boys' books adds strength to the novella's overall critique of the inter-war period and modernism as masculine.
} 
explicit in the description of Jane's clandestine stay in Upleigh, where she eats the pie prepared for Paul and rests in his bed. Mothering Sunday, however, stresses the other, older meaning of "romance" as a class-specific type of literature dealing with marvellous adventures and heroic deeds, with its own (masculine) codes of chivalry, honour, and society. ${ }^{9}$ Revisiting these conventions in a story about a female writer stresses the importance of difference in the act of repetition and points to the feminine as what has been excluded from the very concept of heroic adventure.

By introducing the spectre into the conception of such concepts as heroism or adventure, Swift's book points to what lies outside the concepts, uncovering "what has been forcibly expunged or evacuated" (Hesford, 2005, p. 229) from them and from the system which has produced them. Conjuring up the ghosts from the past of a woman writer, Mothering Sunday playfully re-introduces those elements that have been expunged from the conceptual domain - the tactile, the sensual, the playful, the feminine. Interestingly, Jane's appearance in the masculine space of the Sheringhams' house is linked with a sexual act, thereby supplementing the intellectual with the corporeal, and binding (female) creativity with fecundity. Alone in the house, Jane feels "both more herself, more Jane Fairchild, yet also, as never before, like some visiting ghost" (Swift, 2016, p. 87), so that the day "when she really became a writer" (p. 87) is also the day when her "ghost was - had beenpalpably and unadornedly there" (p. 70), in the library reserved for upper-class men. In fact, libraries are invariably presented in the text as masculine spaces: "the point of libraries, [Jane] sometimes thought, was not the books themselves but that they preserved this hallowed atmosphere of not-to-be-disturbed male sanctuary" (p. 66), thereby making it possible "for men to disappear into and be important in, even though they had disappeared" (p. 89). This emphasis on the masculine provenance of libraries, books, and adventures mirrors the general atmosphere of the time - as Jane states, "everything had a masculine bias in 1924" (p. 126) - and also makes her intervention into the men's world more outrageous, as "few things could be more shocking than for a woman to enter a library naked. The very idea" (p. 66).

The 1920s, the time when Jane discovers that she wants to be a writer, are also regarded as the heyday of modernism, the "art of crisis" that was substantially shaped by the First World War (Bradbury \& McFarlane, 1976, pp. 21, 50), but that was also influenced by the first wave of feminism and the increasing demands for women's political, intellectual, and cultural autonomy. ${ }^{10}$ Reflecting the style of the time, Mothering Sunday adopts a number of modernist conventions, including the focus on a single day, the contrast between the private and the public sphere, the use of third-person narration and free indirect discourse, and the

\footnotetext{
${ }^{9}$ The fact that the novella mentions H. Rider Haggard's King Solomon's Mines (1885) points to another kind of romance, the imperial romance, with whose development Haggard is credited, and thus reinforces the significance of relations between literature and power, with which Swift's book is explicitly concerned.

${ }^{10}$ Sandra Gilbert and Susan Gubar analysed the connection between male modernism and feminism in the second volume of No Man's Land: The Place of the Woman Writer in the Twentieth Century (1989).
} 
emphasis on the subjective experience of time and space (Gee, 2016). Significantly, these conventions are deployed in order to draw a portrait of the artist as a young woman, thereby working to uncover the gender politics of modernism and its enclosure within the masculine, at times masculinist space. In numerous manifestos published at the beginning of the $20^{\text {th }}$ century, modernism was explicitly defined as a male movement, "virile and manly," and was contrasted with "the feminine flabbiness of nineteenth-century writing" (Mullin, 2006, p. 139). ${ }^{11}$ The connection between men and modernism was preserved in critical and educational practices throughout the $20^{\text {th }}$ century, so that in the mid-century the movement was still "unconsciously gendered masculine" (Scott, 1990, p. 2), and "a sense of Modernism as a masculinist movement" (DeKoven, 1999, p. 176) prevailed at the century's end.

Situated against such cultural and conceptual lack of mothers, the young artist in Swift's novella could be seen as "the most miserable and desperate of creatures: no clothes to her back, no roof of her own, and eating someone else's pie" (Swift, 2016, p. 74), ${ }^{12}$ if it were not for the fact that, as Jane declares, "To have no credentials at all. To be given a clean sheet, or rather, to be a clean sheet yourself" seems to be "the perfect basis for becoming a writer-particularly a writer of fiction" (p. 86; emphasis in original). Alluring as the idea of the writer as a clean sheet may be, however, it is almost immediately contradicted by Jane's explanation of her name when, claiming that "Jane is just any old girl's name," she gives examples of such "ordinary" girls as "Jane Austen, Jane Eyre, Jane Russell..." (p. 87), thereby mixing the past with the present and reality with fiction. ${ }^{13}$ This play with references may point to the fact that Jane is a good writer who knows how to manipulate her readers - as she claims, "any writer worth her salt would lead [readers] on, tease them, lead them up the garden path" (p. 132) - but it also shows that "a heritage is never natural" and that it is always heterogeneous (Derrida, 1994, pp. 168, 16), re-constructed, sometimes recovered, through the acknowledgment of the presence of spectres.

As a ghost story that focuses on invisibilities, Mothering Sunday highlights absences, especially those of (literary) mothers, and foregrounds the importance of the continual work of inheriting, as well as the responsibility for choosing what and from whom one inherits.

\footnotetext{
${ }^{11}$ Katherine Mullin illustrates the masculinist strand of modernism by quoting from "Manifesto of Futurism" (1909), where F. T. Marinetti describes the futurists as those who "will glorify war - the world's only hygienemilitarism, patriotism, the destructive gesture of freedom-bringers, beautiful ideas worth dying for, and scorn for woman," and who, together with destroying museums and libraries, "will fight moralism, feminism, every opportunistic or utilitarian cowardice" (as cited in Mullin 2006, p. 137). For the full text of the Manifesto see, for example, J. C. Taylor's Futurism (1961, pp. 124-125).

${ }^{12}$ Swift's heroine seems to repeat here Virginia Woolf's famous call for “A Room of One's Own," first expressed in Woolf's lecture delivered in 1928 and published as an essay in 1929. The need for one's own room is stressed in the novella also by the comparison made between being a maid and an orphan: "And being a maid was a little like being an orphan, since you lived in someone else's house, you didn't have a home of your own to go to" (Swift, 2016, p. 91).

${ }^{13}$ It may be interesting to note that Jane Russell, except for being a famous Hollywood actress, was the founder of the first international adoption programme in 1955.
} 
Focusing on a future writer who educates herself in libraries filled with books about boys, the novella presents inheriting as a very material practice, where how, what, and who inherits is conditioned by what a culture or a society considers worth inheriting. Significantly, the literary heritage that Jane chooses for herself comes from another orphan, Joseph Conrad, whose Youth, a Narrative she reads on the night after Paul's death. ${ }^{14}$ In the story in which Marlow, Conrad's most famous narrator, appears for the first time, Jane discovers a vision of her own future that may be, like Marlow's East, "impalpable and enslaving, like a charm, like a whispered promise of mysterious delight" (Conrad, 1946, p. 37). Yet if Conrad's protagonist finds his "vision" in the open space of the sea, Swift's heroine finds hers in libraries that are closed for maids, except for dusting; moreover, though Jane, like Marlow, is "a youth," she is nevertheless different because, as she notes, in 1924 "there was a way in which 'youth', like 'yarn', had a strongly masculine bias to it. A man could be a 'youth', but a woman?" (Swift, 2016, p. 126). By contrasting Jane with Marlow, Mothering Sunday supplements Conrad's proto-modernist study of male consciousness with an exploration of female personality, and suggests the possibility of a "female modernism" by focusing on the development of a modern woman writer. Significantly, the difference between Marlow and Jane is paralleled by that between Jane and Conrad, in whom she finds someone similar to her, yet different. While Conrad initially seems to her "just one of those boys" (p. 125), reading his books makes Jane see him as an outsider who had to cross "some impossible - impassable - barrier" and learn "to write in a whole new language" in order to become a writer (p. 129; emphasis in original). Encountering his story makes Jane realise that, like Conrad, she too must cross an impossible barrier and find a new language, that of a woman writer, "even though she had a language" (p. 129; emphasis in original).

Mothering Sunday describes Jane finding her vision, or her youth, at a time when "the century was still in its youth," but also when "[y]outh—great swathe of it —was just what the century had lost" (Swift, 2016, p. 127), thereby pointing to the paradoxical simultaneity of death and life, with each opening its own route to a different kind of future. Focusing on a writer's struggles with her past, the book points to the obligation to remember, but at the same time it presents memory as provisional and contingent, and depicts remembering as an active process through which the past may be fabricated rather than simply represented. ${ }^{15}$ The disrupted chronology and elliptical narrative of the novella work to postpone rather than give answers, and also reinforce the image of the present as filled with spectres,

\footnotetext{
${ }^{14}$ Jane discovers Conrad's book in 1924, the year of his death, a fact recorded in the novella which depicts Jane reading the writer's obituary. Although I focus here only on "Youth," which is Jane's first encounter with Conrad, Swift's heroine reads other books by the writer, including Heart of Darkness, Lord Jim, and The Secret Agent.

${ }^{15}$ In this respect, the novella echoes Conrad's "Youth," which the writer described as both "a piece of autobiography" and a "feat of memory" (as cited in Staker, 1999, p. 105); similarly to "Youth," Swift's book blurs the difference between "fictional" and "real" biography, and questions the reliability of the mechanisms of memory. For a discussion of the representation of memory and history in Conrad's "Youth," see Susan Staker's contribution to A Joseph Conrad Companion (1999, pp. 97-124).
} 
some of which may be called forth, while others may have to remain "in the wings of possibility" (Swift, 2016, p. 54). The acknowledgment of the presence of ghosts and the awareness of their role in shaping the future reflect a specifically modern condition and illustrate the early $21^{\text {st }}$-century recognition of the importance of ghosts. In many critical accounts, contemporary cultural production is described as characterised by a return to modernism, yet filtered through the prism of postmodern experience, so that, as Josh Toth argues, it may be possible to describe the present as "a period in which the 'still incomplete project of modernity' is renewed and reassessed in the wake of a postmodern "failure" (2010, p. 88). ${ }^{16}$ Thus, Nicolas Bourriaud defines contemporary culture as the period of automodernism, "a form of modernism for the $21^{\text {st }}$ century," reconfigured through globalisation, cultural nomadism, and creolisation (Bourriaud, 2009), while Alan Kirby proposes to speak of "digimodernism," or "digital modernism," that is a reaction to and a logical effect of postmodernism, and thus implicitly also of modernism, and that should be understood as "a modulated continuity more than a rupture" (Kirby, 2009, p. 1). In what constitutes perhaps the most exhaustive analysis of contemporary culture, Timotheus Vermeulen and Robin van den Akker describe the present as a constant movement and oscillation between modernism and postmodernism, so that the metamodern is neither modern nor postmodern, but always between and beyond these two (2010). What these accounts share, despite their numerous differences, is the intuition that historical and cultural change consists in returns to and repetitions of the past, or of some of its parts, so that "what seems to be out front, the future, comes back in advance: from the past, from the back" (Derrida, 1994, p. 10). This is the image of history, time, and transformation presented in Mothering Sunday, which returns to the ghost of modernism and retrieves some of its others to remind its readers that "the being of what we are is first of all inheritance, whether we like it or know it or not" (Derrida, 2016, p. 54; emphasis in original).

\section{References}

Blanco, M. P., \& Peeren, E. (2013). Introduction: Conceptualizing spectralities. In M. P. Blanco \& E. Peeren (Eds.), The spectralities reader: Ghosts and haunting in contemporary cultural theory (pp. 1-27). London, UK: Bloomsbury.

Bourriaud, N. (2009). Explain altermodern. Retrieved August 12, 2016 from http://www.tate.org.uk/whats-on/tate-britain/exhibition/altermodern/altermodern-explain-altermodern

Bradbury, M., \& McFarlane, J. (1976). The name and nature of modernism. In M. Bradbury \& J. MacFarlane (Eds.), Modernism, 1890-1930 (pp. 19-56). Harmondsworth, UK: Penguin.

Conrad, J. (1946). Youth; Heart of darkness; The end of the tether. London, UK: J. M. Dent and Sons.

\footnotetext{
${ }^{16}$ In this section, I follow Toth's proposal to see the contemporary period as spectral, and to describe epistemic changes in terms of shifts and continuities rather than ruptures $(2010, \mathrm{pp} .5,18)$.
} 
Davis, C. (2005). Hauntology, spectres and phantoms. French Studies, 59(3), 373-379. https://doi.org/10.1093/fs/kni143

DeKoven, M. (1999). Modernism and gender. In M. Levenson (Ed.), The Cambridge companion to modernism (pp. 174-193). Cambridge, UK: Cambridge University Press.

Derrida, J. (1994). Specters of Marx: The state of the debt, the work of mourning, and the new international. (P. Kamuf, Trans.). New York, NY: Routledge.

Ferrebe, A. (2005). Masculinity in male-authored fiction, 1950-2000: Keeping it up. Basingstoke, UK: Palgrave Macmillan.

Hesford, V. (2005). Feminism and its ghosts: The spectre of the feminist-as-lesbian. Feminist Theory, $6(3), 227-250$.

Hynes, S. (1990). A war imagined: The First World War and English culture. London, UK: Bodley Head.

Gee, S. (2016, April 14). Mothering Sunday by Graham Swift. New York Times. Retrieved September 18, 2016 from http://www.nytimes.com/2016/04/17/books/review/mothering-sunday-by-graham-swift.html

Gilbert, S., \& Gubar, S. (1989). No man's land: The place of the woman writer in the twentieth century. Volume 2: Sexchanges. New Haven, CT: Yale University Press.

Gordon, A. F. (2004). Ghostly matters: Haunting and the sociological imagination. Minneapolis: University of Minnesota Press.

Kaczvinsky, D. (2016). Mothering Sunday: A Romance. World Literature Today, 90(5), 85.

Kirby, A. (2009). Digimodernism: How new technologies dismantle the postmodern and reconfigure our culture. New York, NY: Continuum.

Lorek-Jezińska, E., \& Więckowska, K. 2017. Hauntology and cognition: Questions of knowledge, pasts and futures. Theoria et Historia Scientiarum, 14, 7-23. http://dx.doi.org/10.12775/ths.2017.001, 10.01.2018

Mullin, K. 2006. Modernisms and feminisms. In E. Rooney (Ed.), The Cambridge companion to feminist literary theory (pp. 136-152). Cambridge, UK: Cambridge University Press.

Scott, B. K. (1990). Introduction. In B. K. Scott (Ed.), The gender of modernism (pp. 1-18). Bloomington: Indiana University Press.

Staker, S. (1999). Youth (1902) and Tycoon (1903). In L. Orr \& T. Billy (Eds.), A Joseph Conrad companion (pp. 97-124). Westport, CT: Greenwood Press.

Stevenson, R. (2013). Literature and the Great War 1914-1918. Oxford, UK: Oxford University Press.

Swift, G. (2016). Mothering Sunday. London, UK: Scribner.

Taylor, J. C. (1961). Futurism. New York, NY: The Museum of Modern Art.

Toth, J. (2010). The passing of postmodernism: A spectroanalysis of the contemporary. Albany, NY: Suny Press.

Vermeulen, T. \& van den Akker, R. (2010). Notes on metamodernism. Journal of Aesthetics and Culture, 2(1), 1-13. http://dx.doi.org/10.3402/jac.v2i0.5677 
Więckowska, K. (2014). Spectres of men: Masculinity, crisis and British literature. Torun, Poland: Nicolaus Copernicus University Press.

Winnberg, J. (2003). An aesthetics of vulnerability: The sentimentum and the novels of Graham Swift. Göteborg, Sweden: Göteborg University.

Wolfreys, J. (2002). Victorian hauntings: Spectrality, Gothic, the uncanny and literature. Basingstoke, UK: Palgrave.

Wolfreys, J. (2010). Ghosts: Of ourselves or, drifting with Hardy, Heidegger, James, and Woolf. In M. P. Blanco \& E. Peeren (Eds.), Popular ghosts: The haunting spaces of everyday culture (pp. 318). London, UK: Continuum. 


\title{
The Haunting Presence of the Feminine: Virginia Woolf in the Streets of London
}

\author{
Agnieszka Pantuchowicz \\ SWPS University of Social Sciences and Humanities in Warsaw \\ apantuchowicz@swps.edu.pl
}

Received 31 March 2017; accepted 3 October 2017.

\begin{abstract}
Beginning with the theme of the location of haunting in Gothic interiors and the confusion of life and death and the "sub-central" positioning of the feminine as the hidden source of fearfulness, the paper analyzes Virginia Woolf's "Street Haunting: A London Adventure" as an example of a narrative written from the position of the haunting in which the figure of fearful feminine is transformed into a "hauntess" participating in the public world on equal rights with others. Woolf's text, though seemingly positing the protagonist in the position of flâneuse, in fact implicitly criticizes flâneuring as a masculine kind of looking and participating in the public space. Taking place away from home, Woolf's strolling in the streets of London carnivalizes (in the Bakhtinian sense) the activity by way of a joyful blurring of the split between the home and the market. Transgressing what Kathryn Simpson calls "the male privilege of the flâneur" (2010, p. 47) and rendering the transgression as haunting, Woolf evades participation in the masculine world of traffic and exchange by way of bringing the space of the Gothic confinement, and also of entombment, to the public.
\end{abstract}

Keywords: haunting; Gothicism; Virginia Woolf; gender; flâneur; market; London.

Gothic fiction seems to be a literary genre particularly predisposed to be read in the context of haunting as, very frequently, it is about haunting taking place in castles, villas, underground vaults, dungeons which usually constitute central places of action. According to Claire Kahane, "[I]n this dark, secret center of the Gothic structure, the boundaries of life and death themselves seem confused" (1985, p. 334). This confusion, the confusion of life and death, when projected upon human protagonists, results in various genres or species of living-dead haunting both the space of the novel and the readers. As Kahane convincingly argues, illustrating her arguments with Radcliffe's Mysteries of Udolpho, Lewis's The Monk, Shelley's Frankenstein and Austen' Northanger Abbey, hidden beneath the 
secret centre of the gothic is hidden space, a sub-centre of sorts which is "the spectral presence of a dead-undead mother, archaic and all encompassing, a ghost signifying the problematics of femininity" (1985, p. 334). Though the haunting living-dead in the story may be a man, a woman, or even an object (as is the case with the helmet in The Castle of Otranto), prompting this haunting, as it were, from beneath is a "dead-undead" woman, the womblike presence which is the reminder of the unity with the mother, of the presymbolic stage of life which might be called the stage of "nonseparation" in which "the Gothic fear is revealed as the fear of femaleness itself, perceived as threatening to one's wholeness, obliterating the very boundaries of self" (Kahane, 1985, p. 59). Interestingly, for Leona Sherman this nonseparation is a source of fear not only in The Mysteries of Udolpho, which she reads in her "Gothic Possibilities," but also in herself:

I find myself recreating from Gothic my ambivalence toward a femaleness which is my mother in me: nurturing and sexuality, mother and woman and child, conflicted between her and me and therefore in me as me. (Kahane, 1985, p. 338)

The Gothic structure, thus projected upon one's own life, translates life into a gothic story in which haunting is gendered as feminine and which threatens both men and women within whom the mothers cannot be fully repressed, a predicament whose seeming solution Freud found for men in the Oedipal complex, leaving women, as it were, to themselves.

According to Kahane, the mothers hidden in the traditional Gothic surface in the modern Gothic (for instance, in the fiction of Flannery O'Connor and Carson McCullers) which transforms the unseen into the seen, though at the cost of moving the Gothic towards the grotesque: we lose the obscurity of the traditional Gothic darkness which is replaced by the focus on distorted body images. These still haunt us, though the monstrosity of those who haunt seems to be a visibly aesthetic reaction to the grotesqueness of what we see. In both cases, however,

what is seen depends on how women are seen, but that in turn depends on our vision of the mother, a vision that in Gothic fiction is dominated by the uncanny mother of infancy, who will continue to haunt us as long as women remain, on the one hand, the sole custodians of infantile identity, and on the other, on the margin of social power. (Kahane, 1985, p. 351)

Having managed to escape from dark castles to the sphere of public visibility, the feminine is still perceived as grotesque, and its presence is still a haunting presence. This process of failed escape, of failed surfacing, has been aptly encapsulated by Bruno Schulz, whose travel to the foundations of the world in search of authentic beginnings of poetry and creation ends up with "the Mothers," a spectral and infernal space of the beginning of not so much life, as of stories:

We are here at the very bottom, in the dark foundation, among the Mothers. Here are the bottomless infernos, those hopeless Ossianic spaces, all those lamentable Nibelungs. Here are the great breeding grounds of history, factories of plots, hazy smoking rooms of fables and tales. (Schulz, 1979, p. 43) 
While histories, stories, fables and tales surface, "the Mothers" in Schulz's story remain at the foundations, thus Gothicizing the narratives. This haunting may frequently go unnoticed, but it lurks in the "deep structure" which is revealed not only by Gothic fiction, but also by psychoanalysis which in this respect carries a burden of Gothicism. Though Gothic novels can be, and frequently are, analyzed and interpreted in Freudian terms, Robert J. C. Young finds this "exercise" tautological because, as he claims, Freud's The Interpretation of Dreams of 1900 "was in fact a Gothic novel" (1999, p. 2), a story related "through the voice of a medical doctor" $(1999$, p. 12) whose inquiry turns out to be a revelation, or detection, of irrationality. In some stories this haunting of the unconscious may be repressed, but under a scrupulous reading it can always be revealed - to which a lot of psychoanalytic criticism clearly testifies. This revelation inevitably opens up a division into the haunting and the haunted, a division in which the latter are identifiable as "us," while the haunting are posited as them, the them, as in the case of Kahane, being gendered feminine. They are identifiable with "the uncanny mother of infancy," and they "will continue to haunt us." This "us" is thus inclusive of both men and women who, as haunted, would for some reason prefer not to identify with the haunting. This ungendered use of "us" posits an imaginary "general public" as haunted and in fact excludes the perspective of the haunting, silences the voice of the one who haunts. This story of the haunting is a rare kind of narrative. One recent example of such a text is Garrett Cook's $A$ God of Hungry Walls (2015). Though it seems that what haunts in the story is an old house, Cook himself in an interview with Ash Lomen deprives the haunting of even this provisional embodiment claiming that "haunting is bodiless and timeless and runs on its own propaganda" (Lomen, 2017). In Cook's story the haunted and the haunting are narrated in the first person singular by a haunted house which haunts from the position of an omnipotent god in whose power it is to control all feelings and thoughts of those who enter it. The story makes use of a typical model of the haunted interior, be it a house or a castle, the difference being that the voice is given to the haunting itself. This haunting, from the subjective position of the first person singular, expresses its pleasures and joys coming from a slightly sadistic desire to threaten and subject others who enter the house, whose interior functions in the story as the dominion of something which may be called a haunting in itself, a haunting for which the space of the house is but a fragile embodiment of the bodiless and timeless desire of exercising power over the domestic space.

The perspective of the haunting, however, may be quite different and the haunting may take place away from dark and mysterious Gothic interiors. Such a perspective is outlined in a narrative written from the position of an "outed" feminine, from the perspective of a woman who has surfaced from the Gothic dungeon into the public space of the streets of London in Virginia Woolf's essay titled "Street Haunting: A London Adventure" (1927). The word "haunting" appears only in the title of the essay and only once in Woolf's text which seemingly offers only a plain description of streets of London. "Haunting" appears in the last paragraph in which Woolf summarizes her visit to the city, claiming that "to escape is the greatest of pleasures; street haunting in winter the greatest of adventures" (2009, p. 187), thus also expressing the alleged experience of the haunter, of the one who haunts. What 
Woolf simultaneously performs in this sentence is a conflation of haunting with escape and adventure, actually with an escape from the room of one's own, which in the essay figures as a space of a claustrophobic kind of identity. Street haunting is, in fact, an experience of togetherness "after the solitude of one's own room" (p. 177), the room which three years later, in A Room of One's Own, would become the space of writing, of a kind of writing which is a means of escape. In "Street Haunting" the room of one's own is the space where "we sit surrounded by objects which perpetually express the oddity of our own temperaments and enforce the memories of our own experience" (p. 177). The homely interior is felt to be haunted by memories. In the room Woolf feels forced to be herself, confined to the oddity of herself which is, as it were, communicated by the haunting presence of the surrounding objects. The confinement to this kind of haunting, of the passive being haunted, is dissolved in the public space of the streets of London whose active haunting does not bring the pleasure of frightening others, but that of dissolving one's own identity, of becoming more than one, of becoming spectral rather than consolidated into a closed and walled unity created, or made, in the image of a room: "What greater delight and wonder can there be than to leave the straight lines of personality that one is not tethered to a single mind, but can put on briefly for a few minutes the bodies and minds of others" (p. 187).

Woolf's haunting is the feeling of becoming other, a brief and yet liberating experience which also opens up the closed identities of others. Being "tethered to a single mind" is metaphorically reminiscent of being tied to closed space, to a room to which others have no access, and from which there is no access to others. When in A Room of One's Own Woolf is not allowed to enter Cambridge's chapel and library reserved for men only, she thinks about the shut doors of the library in terms of pleasure and displeasure: "I thought how unpleasant it is to be locked out; and I thought how it is worse perhaps to be locked in," seeing in the masculine power of both locking out and locking in the source of "prosperity of the one sex and of the poverty and insecurity of the other" (Woolf, 2005, p. 24). Street haunting is a possibility of going out, but also that of going into the minds of others, where both the prosperous and the insecure become an "army of anonymous trampers" and where, importantly, the haunter loses her identity:

We are no longer quite ourselves. As we step out of the house on a fine evening between four and six, we shed the self our friends know us by and become part of that vast republican army of anonymous trampers, whose society is so agreeable after the solitude of one's own room. (Woolf, 2009, p. 177)

Beth Rigel Daugherty reads the London of Woolf's essay as a city of ghosts, the ghostliness consisting in people's not being themselves. In her reading, the city seems to be a joyful crowd of ghosts who do not really haunt anybody, because the division into the haunting and the haunted seems to be blurred:

Freed by being in public, the numerous people walking in London are accompanied by the ghosts of other selves, other identities. Woolf focuses on pleasure, irresponsibility even - the joy of the essay is apparent - as she traces the process of observation: the skimming of surfaces, the imagining of other people's inner worlds, and the entering of other people's social constructs. (2010, p. 191) 
Woolf's haunting is a joyful kind of activity which "carnivalesques" the city space. If Bakhtin located the practices of carnival in "a completely different, nonofficial, extraecclesiastical and extrapolitical aspect of the world, of man, and of human relations" (Bakhtin, 1984, p. 6), the space of Woolf's London is not only a scene of joyful dancing of the crowd away from institutions, but also a space which deconstructs the solidity of architecture, a space in which people are coming out of crannies rather than from homes in order to join others in the peculiar celebration of the everyday: "In what crevices and crannies, one might ask, did they lodge ... ?" (2009, p. 181). Even the dwarf she sees in a boot shop "had started a hobbling grotesque dance to which everybody in the street now conformed" (2009, p. 180). Though she herself is not singled out in the crowd, her haunting presence seems to be enchanting the street and suspending the laws of identity and, importantly, the laws of economy. At one point in the text the power of her gaze transforms everything she sees in Oxford Street into an unmarketable treasure:

Passing, glimpsing, everything seems accidentally but miraculously sprinkled with beauty, as if the tide of trade which deposits its burden so punctually and prosaically upon the shores of Oxford Street had this night cast up nothing but treasure. With no thought of buying, the eye is sportive and generous; it creates; it adorns; it enhances. (2009, p. 181)

The mechanism of this generous creativity, of the disinterested enhancement and enrichment of the world involves a peculiar change. Going out from the room, going haunting, involves a crucial transformation, a change from the geometrical squareness of a roomshaped identity into a monstrously enhanced organ of vision which Woolf describes as "a central oyster of perceptiveness, an enormous eye" (2009, p. 178). Though this eye seems to be an objective observer of surfaces, it sees, as it were, something different from what seems to be there. It is not an inquisitive eye, it does not look into things beyond their surface in search of truths or essences of things:

[A]fter all, we are only gliding smoothly on the surface. The eye is not a miner, not a diver, not a seeker after buried treasure. It floats us smoothly down a stream; resting, pausing, the brain sleeps perhaps as it looks. (2009, p. 178)

This description of the "enormous eye" seems to be that of an objective device seeing things as they are. What is thus revealed and celebrated is not only Bakhtin's "gay relativity of prevailing truths and authorities" (Bakhtin, 1984, p. 11) but also a world without the calculative reason, or brain, of economy which is replaced by pleasures coming not from appropriation, but rather from observation. This, along with the motif of walking in the city, is in obvious ways reminiscent of the Baudelaire-like figure of the flâneur, of the observerwalker in the metropolitan city, the figure which, as Ching-Fang Tseng notices, is frequently "considered the hero of modernism and an emblem of modernity" (2006, p. 223). The flâneur is what Michel de Certeau calls the "voyeurgod" who sees everything without being seen. He is also, as in the writings of Walter Benjamin, a master-collector of scattered images to be put together so as to evoke the feeling of mastery over the whole city. The flaneur in no way intervenes into the city environment which he observes and, importantly, positions himself between the home and the city space. What characterizes the flâneur is 
that, as Charles Baudelaire states, "in his cradle, a fairy has bestowed the love of masks and masquerading, the hate of home, and the passion for roaming" (Tseng, 2006, p. 234; emphasis added). Or, as Baudelaire puts it in "The Painter of the Modern Life," the desire of the flâneur is "[t]o be away from home and yet to feel at home anywhere, to be at the centre of the world, and yet to be unseen of the world" (Tseng, 2006, p. 223).

Reading Woolf's essay in the light of the idea of flâneuring, I will try to argue with Cheryl Hindrichs's claim that she "took up the tradition of the flâneur as a means of defamiliarizing our habitual narratives and institutions" (2009, p. 319). Rather, as I will try to show, her walk in the streets of London is subversive of the very division into public and private along with the roles assigned to the participants in both spheres. Thus, without going deeply into various and numerous theorizations of the flâneur figure, I will use it only as a counterpoint to the experience of haunting which speaks through Woolf's text.

Baudelaire's nineteenth-century flâneur walked in the city which was a masculine gendered sphere and in which the public presence of women was restricted. When in 1831 George Sand wanted to experience Paris life, she did it dressed as a boy:

So I had made for myself a redingote-guérite in heavy gray cloth, pants and vest to match. With a gray hat and large woollen cravat, I was a perfect first-year student. . . . It seemed to me that I could go round the world. And then, my clothes feared nothing. . . . No one knew me, no one looked at me, no one found fault with me; I was an atom lost in that immense crowd. (Wolff, 2004, p. 9)

What fascinated Sand was not what she saw, but her invisibility in the crowd which was also an illusion of independence. The disguise, as Janet Wolff observes, "made the life of the flâneur available to her; as she knew very well, she could not adopt the non-existent role of a flâneuse. Women could not stroll alone in the city" $(2004$, p. 9). It was only since the early decades of the twentieth century "that shopping has come to betoken for middleclass women the recently legitimized freedom of walking in the public spaces" (Tseng, 2006, p. 247). This new freedom was a freedom offered by such shopping spaces as arcades which, for Walter Benjamin, constituted a dual image of "house no less than street. Such an image is the prostitute-seller and sold in one" (2000, p. 10). The duality of this space does not simply translate the woman going out shopping into a flâneuse, a feminine version of the flaneur; it in fact constitutes a kind of threat to the flâneur's alleged independence and autonomy. Shopping poses a threat to the flâneur, Priscilla Ferguson notes, "because it severely undermines the posture of independence that affords the flaneur his occupation and his raison d'être" (1994, p. 27). A shopping woman, on the other hand, cannot be a flâneuse because doing shopping she is tied to the home, cares for it, and thus herself is split between two kinds of space, between the home and the market. Both these spaces “signify her husband's economic power" (Tseng, 2006, p. 235).

In "Street Haunting" shopping constitutes only a kind of excuse to go out: "[W]hen the desire comes upon us to go street rambling the pencil does for a pretext, and getting up we say: 'Really, I must buy a pencil'” (Woolf, 2009, p. 177). The pencil does not function simply as a desired commodity in the story, but develops a metaphorical association of 
haunting with writing, with writing as a pretext, or "pre-text," for going out of the room without a desire to appropriate the world, even to describe it. "Street Haunting" supplements the home with a spectral illumination of streetlights which is brought back to one's room along with the pencil, with the possibility of writing from within the room which thus becomes a room of one's own, a home independent of the masculine economic power. The essay ends with an unspoiled return from the haunting expedition whose trophy is almost nothing, a lead pencil described as a treasure:

Here again is the usual door; here the chair turned as we left it and the china bowl and the brown ring on the carpet. And here-let us examine it tenderly, let us touch it with reverence - is the only spoil we have retrieved from all the treasures of the city, a lead pencil. (Woolf, 2009, p. 187)

The pencil is not exactly an object of desire of the feminine walker in the essay. What she wants seems to be writing as a task and an effect of haunting, a haunting which, importantly, is not dreadful in the text. She easily identifies herself with both the inside and the outside, with me and not me, thus avoiding what Judith Butler calls in The Psychic Life of Power the refusal of identification governing the construction of masculinity which is "haunted by a dread of being what he wants" (1997, p. 137). This dread results in an imaginary mastering of what is, in fact, not wanted. There seems to be no dread in Woolf's haunting, and it is perhaps for this reason that using the word "haunting" in the title of the essay and embracing the inarticulacy of this "activity" she refuses to perform the repudiation of that inarticulacy, and this refusal itself may be seen as a refusal to articulate, or express sexuality. If gender, as Butler claims, "is composed of precisely what remains inarticulate in sexuality" (1997, p. 140), then the feminine haunting of the streets of London seems to be exactly an expression of this inarticulacy. The feminine haunting does not express a disguised wish, or desire, for the pleasures of strolling, or for flâneuring, as underlying this activity there is a highly articulate expression of separation from the world, of the pleasure of being independently sovereign. This sovereignty is also expressive of the superiority of the stroller over other, non-strolling creatures. In Louis Huart's Physiologie du Flâneur (1841) strolling was used as a defining feature of being human: "Man rises above all other animals only because he can stroll" (Pollentier, 2010, p. 20). Among the creatures excluded from the flânerie, Caroline Pollentier observes, are those who were excluded from the city in Aristotle's "political conception of the polis" which "has persistently been thought of as a distinctively human environment. Excluding slaves, women, animals, and all that is not man, the Aristotelian polis delimits the political sphere of citizenship" (2010, p. 20). Virginia Woolf in her short essay brings in a "politics of space" in which participation in the public sphere need not be divided and distributed in accordance with the gendered divisions of space into the public and the domestic. She evidently trespasses on what Simpson calls "the male privilege of the flâneur" (2010, p. 47), but the transgression, described as haunting, does not consist in participating in the masculine world of traffic and exchange, but in bringing the space of the Gothic confinement, and also of entombment, to the public. What Woolf's haunting also enables is what Susan 
Squier calls an "imaginative passage into many lives" achieved by stripping of "the defining and limiting possessions of the private home" (Squier, 1983, p. 494). This is done, moreover, in a slightly carnivalesque fashion, among the crowd and "the excesses of commodity display" (Simpson, 2010, p. 47). Woolf's haunting, through its feminine gendering, posits the marketplace of London as haunted not from the insides of its houses, but rather, paradoxically, from within the seeming exteriority and openness of the public space which turns out not to be immune to the spectrality of its own making, the spectrality effected through the haunting presence of the feminine gendered haunter in the space of the otherwise fair city of London.

\section{References}

Bakhtin, M. M. (1984). Rabelais and his world. (H. Iswolsky, Trans.). Bloomington: Indiana University Press.

Benjamin, W. (2000). The Arcades Project. (H. Eiland \& K. McLaughlin, Trans.). Cambridge, MA: Harvard University Press.

Butler, J. (1997). The psychic life of power: Theories in subjection. Stanford, CA: Stanford University Press.

Cook, G. (2015). A god of angry walls. Portland, OR: Deaddite Press.

Daugherty, B. R. (2010). The streets of London: Virginia Woolf's development of a pedagogical style. In E. F. Evans \& S. E. Cornish (Eds.), Woolf and the city (pp. 190-194). Liverpool, UK: Liverpool University Press.

Ferguson, P. P. (1994). The flâneur on and off the streets of Paris. In K. Tester (Ed.), The flâneur (pp. 22-42). New York, NY: Routledge.

Hindrichs, C. (2009). Feminist optics and avant-garde cinema: Germaine Dulac's "The Smiling Madame Beudet” and Virginia Woolf's "Street Haunting." Feminist Studies, 35(2), 294-322.

Holland, N., \& Sherman, L. (1976). Gothic possibilities. New Literary History, 8, $279-94$.

Kahane, C. (1985). The gothic mirror. In S. N. Gardner, C. Kahane, \& M. Sprengnether (Eds.), The (m)other tongue: Essays in feminist psychoanalytic interpretation (pp. 334-351). Ithaca, NY: Cornell University Press.

Lomen, A. (2017). Inside a god of haunted walls: An unconventional interview with Garrett Cook. Retrieved March 7, 2017 from https://yesclash.com/2017/01/12/inside-a-god-of-haunted-wallsan-unconventional-interview-with-garrett-cook/

Pollentier, C. (2010). Imagining flânerie beyond anthropocentrism: Virginia Woolf, the London archipelago, and city tortoises. In E. F. Evans \& S. E. Cornish (Eds.), Woolf and the city (pp. 20-30). Liverpool, UK: Liverpool University Press.

Schulz, B. (1979). The fictions of Bruno Schulz. (C. Wieniewska, Trans.). London, UK: Picador.

Simpson, K. (2010). "Street haunting," commodity culture, and the woman artist. In E. F. Evans \& S. E. Cornish (Eds.), Woolf and the city (pp. 47-54). Liverpool, UK: Liverpool University Press. 
Squier, S. (1983). "The London scene": Gender and class in Virginia Woolf's London. Twentieth Century Literature, 29(4), 488-500.

Tseng, C. (2006). The flâneur, the flâneuse, and the hostess: Virginia Woolf’s (un)domesticating flânerie in Mrs. Dalloway. Concentric: Literary and Cultural Studies, 32(1), 219-258.

Wolff, J. (2004). The invisible flâneuse: Women and the literature of modernity. In C. Jenks (Ed.), Urban culture: Critical concepts in literary and cultural studies, Vol.2 (pp. 3-16). London, UK: Routledge.

Woolf, V. (2009). Street haunting: A London adventure. In Selected essays (pp. 177-187). Oxford, UK: Oxford University Press. (Original work published 1927)

Woolf, V. (2005). A room of one's own. Orlando, FL: Harcourt. (Original work published 1929)

Young, R. J. C. (1999). Freud's secret: The Interpretation of Dreams was a Gothic novel. Retrieved January 21, 2017 from http://robertjcyoung.com/Freudssecret.pdf 



\title{
Haunting Poe's Maze: \\ Investigative Obsessions in the Weird Fictions of Stefan Grabiński and H. P. Lovecraft
}

\author{
Pawel Pyrka \\ SWPS University of Social Sciences and Humanities in Warsaw \\ ppyrka@swps.edu.pl
}

Received 16 August 2017; accepted 30 October 2017.

\begin{abstract}
The article is a comparative reading and analysis of selected works by two eminent authors of weird fiction, Stefan Grabiński and Howard Phillips Lovecraft, the goal of which is to trace two (independent) trajectories of development of ideas concerning "weird" story writing, as established, in pre-modern context, by Edgar Allan Poe. The two authors appear to suffer from a combination of tragically inherent inability to write "like" Poe, with a haunting desire to do so. Exhibiting understanding of the Poesque discourse, they are driven to invent strategies to cope with the resulting textual neuroses - a way out of the discursive "maze" of Poe's craft, a way that is always already shut.

Where Lovecraft's “mechanistic materialism" finds its expression in an indifferent cosmos, populated by alien beings, whose influence seems to be inscribed in the fabric of his textual realities, Grabiński's sense of "amazement" is deployed internally, with psychological constructs overshadowing the "objective" reality. Both discourses, however, spring from one tradition of horror, and from the unexorcised trace of Poe's spectre. The two authors' ambivalent relation with modern sensibilities results in a series of obsessive investigations into the ideological underpinnings of art, philosophy and science.
\end{abstract}

Keywords: weird fiction; Poe; Lovecraft; Grabiński; haunting; obsession. 


\section{Tracing the Labyrinth}

Edgar Allan Poe's 1843 story “The Tell-Tale Heart” opens with the following confession:

It is impossible to say how first the idea entered my brain; but, once conceived, it haunted me day and night. Object there was none. Passion there was none. I loved the old man. He had never wronged me. He had never given me insult. For his gold I had no desire. I think it was his eye! (Poe, 2011, p. 284)

The passage gives voice to the murderer's own admission and definition of his obsession and its pattern of development into murderous compulsion. And yet inevitably, the narrator's words explain very little to the readers, instead planting in their minds that very same species of an idea, one supposed to haunt them day and night, with no apparent goal, no identifiable emotion, and, as it turns out, no intellectual satisfaction to be had in the end. The narrative voice thus becomes that of a siren, luring readers into the labyrinth of lies, initiating a play of uncertainties, constructed and enacted with the neatness available only to obsessive-compulsive minds and texts.

Poe's preoccupation with, and emphasis on, structural unity, expressed in "The Philosophy of Composition" (Poe, 1984, p. 13), allow precisely for such a mode of entrapment. Envisioning a text as a carefully designed undertaking, a structured experience, directing the mind of the reader through a series of narrative encounters leading to a very specific place, enhances the sense of highly organized mental space in which Poe's characters exist. The maze-like structures emerge from the texts in the form of a dilapidated family estate (accompanied by family relations of disconcerting complexity), twisting and turning underground passages and vaults beneath a palazzo, labyrinthine streets of a crowded metropolis, or, strikingly, intricacies of irrational thought produced by the texts' narrators.

Immersed in the text and "a-mazed" by its confines, the reader intuitively seeks a way out, frequently intoxicated by the strangeness of the circumstances and enamoured with the idea of the final revelation - one capable of offering peace to the obsessing mind. And yet, more often than not, they are thrown back to the beginning, the state of confusion, without any real progress, absent answers and understanding, walled in like the unfortunate Fortunato, punished for some imagined slight (Poe, 2011, p. 214). And so the journey through the maze becomes in a sense the sum total of the experience: as the house of Usher falls (Poe, 2011, p. 195), as Ligeia reinserts herself into the narrator's life (2011, p. 410), as the tell-tale heart beats towards the frantic confession, the text closes, the narrative voice loses its power to describe, the seeking mind of the reader hits the wall of the labyrinth.

Poe's maze, envisioned as a "dream within a dream," and constructed to be "seen" and to "seem" (Poe, 2011, p. 675), on the crossroads of reality and fiction is in effect already an apparition, a half-being. A set of textual restrictions in the form of silences, understatements and displays of circular narrative logic, the labyrinth emerges as at once a metaphor of psychological entrapment and an epistemological quest for answers. It is a structure which must always be explored, a veil to be pierced, a cypher to be decrypted, revealed 
and unearthed. The labyrinth's traditional meaning as the ritualized realization of the pattern of navigation through space on a journey, or pilgrimage to "the center" (Veel, 2003, p. 154) attains a new meaning when studied as an organized mental (and literary) structure. In fact, since it could be said that all "literary thinking is akin to walking a labyrinth" (Bloom \& Hobby, 2009, p. xvi), Poe’s maze is but a more direct expression and actualization of the metaphor within his texts. His reader is made to experience its qualities internally, while a critic-successor might at the same time observe externally the overall, ordered structure of the enterprise. Still, the experience is inevitably marked by a sense of perplexity. As Kristin Veel writes:

Essentially, navigation has to do with the distinction between overview and embeddedness. In the changes in the labyrinth motif one can thus identify alterations in the relation between the view from above and the experience of moving inside the labyrinth. This interweaving of the two different points of view from which the labyrinth can be observed makes it an ambiguous motif, and allows for the labyrinth structure (even in its most simple one-pathed form) to be interpreted as simultaneously order and disorder, clarity and confusion, unity and multiplicity, artistry and chaos. The labyrinth walker, whose vision is constricted and fragmented, is overtaken by confusion, and his/her experience of the labyrinth is one of disorder, multiplicity, and chaos, whereas the labyrinth viewer, able to overlook the complete structure, will get a sense of order, clarity, unity, and artistry. (Veel, 2003, p. 156)

The resulting duality is effectively expressed and embodied within Poe's texts in the figure of the character-narrator, who takes on the qualities of both the "walker" and the "viewer" of the structure, while its effects are transferred to an immersed reader, imprinting them with a play of uncertainties.

Poe's carefully orchestrated dance between the rational and the fantastic is made possible by the unreliable voice of the storyteller, but also makes evident the underlying opposition between the two notions, luring the reader into believing the conflict can be resolved and curiosity satisfied. The existence of this opposition, or perhaps rather the belief in its fundamental character is what Poe's fiction can comfortably rest in. The writer's, reader's and characters' investigations are both enabled and fuelled by a set of assumptions emanating from the context of romantic tradition and that of $19^{\text {th }}$ century America. The "ratiocination" cycle, originating with "The Murders in the Rue Morgue" (2011, p. 63), illustrates this too, by applying an apparently rational method, only to arrive at a truly unbelievable explanation. The readers of the story are inevitably surprised and amazed by the revelation of a razor-wielding man-mimicking Ourang-Outang, and find themselves back in the labyrinth. Poe's explorations rely therefore on the conviction that the parameters of subjective and objective experience are relatively stable, puzzles and cyphers can be solved, the walls of the labyrinth do not shift, and fiction is necessarily stranger than reality.

Frequently described as Poe's literary descendants, both Howard Phillips Lovecraft and Stefan Grabiński openly stated the importance of his literary output for their own work (Grabiński, 1931; Lovecraft, 1974). Their own original textual realities, whether surrounded by hostile and ancient cosmos as in the case of the former writer, or carefully delineated by means of thematic compartmentalization and condensation practiced by the 
latter, carry the touch of Poe's literary brand, along with the mental trace in the form of "scars" and preoccupations of Poe's entrapped reader. In a sense, both authors are explorers, traversing Poe's maze, testing its limits, and adding new remodelled sections to the edifice, while at the same time, despite their overt desire to replicate their antecedent's originality (a paradoxical enterprise, indeed) in terms of style and themes, they too fall into the trap of the labyrinth. Having eagerly absorbed Poe's language, their own investigations are always already filtered through their antecedent's creative and linguistic experience; they are forever haunted by Poe's spectre. Consequently, the Derridean trace, as discussed in Of Grammatology, can here be seen in the form of dynamic (or unfolding) absence of Poe's present(ed) pre-text, a scar forming on the tissue of text.

There is in their texts an implicit need to conquer and capture reality (at times, it seems, stronger than that of Poe), to bind it within the walls of stable categorizations, through application of scientific investigation, a superscience of the spiritual or psychological, a superlogic of obsession, perhaps, which, while dangerous in their revelations, forces, and drives, is expected to offer an explanation.

\section{New, Alien Mechanics}

H. P. Lovecraft's stories frequently revolve around the invasion of the accepted, or normative reality, by ancient (and so historicized), buried or forgotten (and so repressed) and cosmic or extradimensional (and so externalized) forces. While Poe's discourse is secure in its perception and expression of mystified (abnormal) mentality, and satisfied by the quirks of unfathomable human soul, Lovecraft seeks methodical, almost mechanical, elucidation of the masked signified (Joshi, 1996; Joshi \& Schultz, 2001).

In "Arthur Jermyn" the reader accompanies the main character on an investigation into his family's genealogical past, which reveals a pattern of cultural transgressions, miscegenation, and finally interspecies breeding. The reader is presented with a collection of figures, taken as if on a guided tour through the Jermyns' ancestral gallery. The family narrative is historicized via the use of chronological references and localized settings, while the introductory paragraph, itself one of Lovecraft's most famous statements about science, is clearly aimed, if not completely effective, at validating its almost "academic" status:

Life is a hideous thing, and from the background behind what we know of it peer daemoniacal hints of truth which make it sometimes a thousandfold more hideous. Science, already oppressive with its shocking revelations, will perhaps be the ultimate exterminator of our human species - if separate species we be - for its reserve of unguessed horrors could never be borne by mortal brains if loosed upon the world. If we knew what we are, we should do as Sir Arthur Jermyn did; and Arthur Jermyn soaked himself in oil and set fire to his clothing one night.

No one placed the charred fragments in an urn or set a memorial to him who had been; for certain papers and a certain boxed object were found which made men wish to forget. Some who knew him do not admit that he ever existed. (Lovecraft, 1999, p. 14) 
Arthur Jermyn's self-immolation is an attempt at purification, a purging of the world, an erasure of an abomination he discovered himself to be. The ending is thus not unlike in some of Poe's stories. The origin of his destruction is rooted in history, and the act is facilitated by a scientific investigation, with each stage fuelling the character's growing obsession and the reader's horror at the immensity of transgression. However, unlike Poe, Lovecraft relies on otherness, biological, cultural and ethical, to evoke the reaction of the reader. The story portrays life as "hideous" but also as an experience burdened by (ideological) obfuscation, with "daemoniacal" truths being separated from humanity by the distance of insufficient knowledge.

"The Statement of Randolph Carter" is another of Lovecraft's tales, depicting an obsessed investigator exploring the far reaches of consensus reality. The narrator is an apparently reluctant participant in his friend Warren's occult research and accompanies him on the journey to a swamp graveyard, in order to find and enter a portal into another world, inhabited by "demonic" entities. The research is sparked off by a mysterious book of forbidden knowledge, which Carter's partner guards closely, unwilling to share its secrets. Carter is unable to recall any details of their study, a fact which he sees as "merciful" in the end, nor can he admit any conscious interest in his friend's pursuits, instead referring to his state of mind as "reluctant fascination." The latter of course places the decision to interact with the "other world" in a sense beyond his control. As Warren enters the tomb he begins to communicate his experience with the use of a telephone wire. Despite the trappings of scientific research reinforced by the application of the latest technological devices, the words which reach Carter's ears exemplify, once again, Lovecraft's linguistic preoccupation with the "unnamable" and "indescribable," the facets of indeterminate and indeterminable "outer" reality:

God! If you could see what I am seeing!”

I could not answer. Speechless, I could only wait. Then came the frenzied tones again: "Carter, it's terrible - monstrous — unbelievable!"

This time my voice did not fail me, and I poured into the transmitter a flood of excited questions. Terrified, I continued to repeat, "Warren, what is it? What is it?"

Once more came the voice of my friend, still hoarse with fear, and now apparently tinged with despair: "I can't tell you, Carter! It's too utterly beyond thought—I dare not tell you —no man could know it and live - Great God! I never dreamed of THIS!

(Lovecraft, 1999, p. 11; emphasis in original)

Warren orders Carter to immediately flee the place and then falls silent. After a while, and after Carter's numerous desperate attempts to communicate through the wire, a reply finally comes: "YOU FOOL, WARREN IS DEAD!" (Lovecraft, 1999, p. 13; emphasis in original).

Warren is thus literally consumed by the "other side," while the reader, like Carter, is shown to have been foolish to believe the mystery can be pierced. The voice which speaks the final words of the story is described as "hollow, gelatinous, remote, unearthly, inhuman, disembodied" (Lovecraft, 1999, p. 13), the adjectives whose extensive use has gained Lovecraft 
the opinion of poor stylist, while at the same time inspiring a special brand of occasionally "reluctant" fascination in his followers. Simultaneously "gelatinous" and "disembodied," the origin of the voice brings metonymic associations of at once organic and spiritual nature.

Lovecraft clearly and intentionally externalizes the threat of identity's dissolution and does it to find his own way out of the labyrinth of Poe's legacy. Intent on developing and building upon his master's voice, he is, however, unable to escape either the cultural fears or personal insecurities, creative, ethical and otherwise. Jermyn's self-destruction and Warren's extinction resemble Poe's silencing of the narrative voices, but are marked by a reactionary response towards the modernist crisis of reference. The reality they inhabit has been transformed, the rules shifted to accommodate an "alien evil" greater than human inadequacy and weakness. Lovecraft draws his horror out of his readers' and his own anxiety about the precarious state of ideas and values, which, when translated into fiction, emerges in the form of artificial mythology, alien physiology, and non-Euclidean geometry, all designed to explain the world where things fall apart.

\section{Obsession's Will to Empower}

Stefan Grabiński was an author of novels, plays, and short stories which can be broadly classified as weird fiction. Frequently referred to as "Polish Poe," or "Polish Lovecraft," Grabiński wrote tales in the genre he himself called "psychofantasy" or "metafantasy" (Grabiński, 2012, p. 302). Both terms immediately evoke associations with inner, rather than outer experience of characters and textual world as foregrounded in his writing, and suggest a special significance awarded to products of psyche, be they fantasies, nightmares, hallucinations, desires, or phantom objects.

Grabiński's confessed admiration of Poe's work and fascination with his literary ideas is clearly visible in his selection of themes, his chosen vehicle of expression and stylistic precision. Like Lovecraft, he embraces signs of scientific and technological progress and employs them in his writing, constructing a powerful and realistic vision of a dynamic world, inhabited by characters whose actions (and ideas) affect and transform it. Contrary to Lovecraft's projections of cosmic magnitude, however, Grabiński sharply narrows his focus to the point at which a story becomes an intimate encounter with the protagonist and their perception of reality evoked in the text.

"Vengeance of the Elementals" tells the story of fire chief Antoni Czarnocki who, apart from being an active firefighter and a veteran of numerous infernos, is a theorist of flames, conducting extensive research into the phenomenon of fires:

The fruits of this long-standing research were the special "fire maps" and "fire modifications" drawn up by him. On the first were emphasized places, buildings and houses which had passed through some catastrophe, no matter if the traces of the fire were eliminated and the damage repaired, or if the fire site had been left to its own fate. The plans called "fire modifications" underlined the changes that had occurred in the arrangement of homes and buildings as a result of a fire disaster; any shift or the slightest alteration was marked with amazing pedantry. (Grabiński, 1993, p. 73) 
Czarnocki's work is an attempt at mastering the contingency of fire-related incidents by means of science, but perhaps more importantly, it strives to connect the statistical data to the dynamic morphology of urban space, which as a fire chief he sees as his domain and responsibility. His approach, though seemingly based on scientific principles, results in revelations of unusual nature:

Connecting various fire sites with lines, he became convinced that in four out of five times the fire points created outlines of strange figures. Primarily these were the shapes of short, funny beings that sometimes reminded one of child freaks, at other times, of animals - little monkeys with long, playfully turned tails, agile bow-legged squirrels, extremely hideous talapoins. (Grabiński, 1993, p. 73)

This discovery he also translates into a physical form, this time of an artistic kind - the Album of the Fire Elementals:

The second part of this work was Fragments and Designs - a multitude of grotesque figures, incomplete forms, barely developed ideas. Inside were sketches of vague heads, fragments of trunks, parts of arms and legs, segments of hairy, spread-out paws, interspersed with halftwisted figures, mangled things and tentacle growths. (Grabiński, 1993, p. 73)

Filtered through Czarnocki's perception, the fruit of his scientific labour attains the form of miniature monstrosities, which, after immersing himself in the study of mythology, folklore and mystical writings, he becomes convinced are entities responsible for the appearance of fires.

Perhaps as a result of his obsession, Czarnocki also acquires an almost uncanny ability to avoid any harm caused by flames, gaining him a nickname of "fireproof." Confident in this invulnerability, Czarnocki wages war on the elementals, which apparently respond in kind, trying to destroy him indirectly, by means of a falling beam or a heavy crossbar intended to crush him, or clouds of carbon dioxide in his home. Czarnocki prevails and moreover finds himself an addressee of hidden messages encoded in patterns visible on the surface of unburned coal. Despite being apparently fireproof, the fire chief has a weakness, an affliction in the form of involuntary astral projection, which in the end allows the elementals to possess his body and start multiple fires in key locations of the city. His body confined to a mental institution, Czarnocki's spirit is left behind, with nowhere to return to.

Another story by Grabiński which discusses the consequences of obsessing mind is "The Area." The protagonist, Wrześmian, is an author of strange and enigmatic fiction, misunderstood, or perhaps never really understood at all, who stops writing and removes himself from the public view completely, choosing instead to exist solely in the world of his dreams, fantasies and fictions. Wrześmian is a believer in the creative power of thought, its ability to transcend laws of nature and affect and shape the material world:

He had acquired as time went on the firm conviction that any thought, even the most audacious, that any fiction, even the most insane, can one day materialize and see its fulfilment in space and time.

"No person thinks in vain; no thought, even the strangest, disappears fruitlessly," he used to repeat many times to his circle of friends and acquaintances. (Grabiński, 1993, p. 29) 
The claim seems in a sense to echo Ligeia's rebellious statement about the power of will, its ability to conquer death.

As years go by, Wrześmian's ideas, for lack of expression through projection on paper, gain even more vitality and finally a life of their own. He becomes fascinated with an abandoned and empty house, which he observes for days on end until one evening he sees a grotesque face in the window, then another one, and another and so on. The empty villa becomes populated with his materialized thought content, and so he has no choice but to investigate. As he sneaks into the house, he becomes surrounded by a host of apparitions, demanding to be given "full" expression:

They surrounded him in an increasingly closed circle. From pale, bloodless lips flowed out a menacing whisper: "It's him! It's him!" He stopped and looked defiantly at the throng: "What do you want from me?" "Your blood! We want your blood! Blood! Blood!" "What do you want it for?" "We want to live! We want to live! Why did you call us out from the chaos of non-existence and condemn us to be miserable half-corporeal vagrants? Look at how weak and pale we are!" (Grabiński, 1993, p. 35)

Unable to escape, Wrześmian is consumed by the apparition in a gory feast of blood and flesh.

The final scene of the story shows a vat standing in the corner of the house, for years a receptacle of the writer's discarded thoughts, rejected ideas, and half-conscious fantasies, bubbling with oozing matter. Then something emerges:

A couple of large, distended bubbles escaped, and a misshapen stump of a hand appeared. Some sort of torso or framework emerged from the depth, dripping with water, covered with mould and a cadaverous putridity - maybe a man, beast or plant. This monstrosity glinted its amazed face toward the sky, opened spongy lips wide in a vague imbecilic-enigmatic smile, extracted from the vat legs twisted as a thicket of coral, and, shaking the water off, started to walk with an unsteady, swinging step.... (Grabiński, 1993, p. 35)

The entity, a sort of mental version of Frankenstein's creature, walks out of the house and into the world, and finally vanishes in the distance with the first light of dawn.

Grabiński's experience in the maze-like literary house of Poe is thus far more internal and intimate. His characters are shown to collapse onto their own mental plane, giving the reader a sense of closing, if not closure, and enhancing the claustrophobic nature of inner experience. Even more than Lovecraft, with his emphasis on the randomness, chaos and insignificance of human existence, Grabiński traces in fascinating and painful detail his characters' mental journeys, their odyssey towards the inevitable dissolution.

\section{Persistent Amazement}

Both Lovecraft and Grabiński exhibit the symptoms characteristic for the victims of entrapment in the textual labyrinth. There is in their writing an integral and inseparable strain of Poe's literary diction; they are always and already his readers, prior to their own voice, who speak in a language of horror, haunted, but ultimately made complete and possible 
by their antecedent's never-absent spectre. Its persistence may, in fact, lead us to call into question, and perhaps nullify, even the seemingly clear antecedent-to-successor relation. As Marek Wilczyński states:

in "the extraordinary case" of Lovecraft and Poe, both components of the hypertextual relationship lose their proper identity so that it becomes impossible to tell one from the other ... the borderline separating the hypertext from the hypotext is erased and the fundamental of their sequence annihilated. (1992, p. 168)

A similar argument may be put forward in the (equally "extraordinary") case of Grabiński, whose Poesque "phantom scar" is more structural than thematic, making his "haunting" a constructivist enterprise.

China Miéville, one of the contemporary heirs to the horror tradition, describes Grabiński's work in the following words:

Where Poe's horror is agonised, a kind of extended shriek, Grabinski's is cerebral, investigative. His protagonists are tortured and aghast, but not because they suffer at the caprice of Lovecraftian blind idiot gods: Grabinski's universe is strange and its principles are perhaps not those we expect, but they are principles - rules - and it is in their exploration that the mystery lies. (Miéville, 2003, para. 3)

As the wellspring of essence, which to some extent nourished Poe's romantic playfulness, this insidious paradigmatic oscillation between the rational and the fantastic appears to have dried out in Lovecraft and Grabiński's time, the two authors are forced to blaze a new path out of both Poe's and their own maze of textual, cultural and psychological obsessions. To quote Harold Bloom once again, "All literary influence is labyrinthine; belated authors wander the maze as if an exit could be found, until the strong among them realize that the windings of the labyrinth all are internal" (Bloom \& Hobby, 2009, p. xvi). Poe's maze, its spectral half-presence, thus serves as a "missing link" between the two masters of weird fiction (Wilczyński, 2008, p. 536), a transatlantic bridge and an "interpretant connecting Lovecraft and Grabiński” (Wilczyński, 2008, p. 531). Having adopted different trajectories and artistic philosophies in reaction to the challenges of modernity (Lovecraft's reactionary, and at times, nihilistic mode and Grabiński's earnest, if concerned, fascination with progress and technology's impact on individual psyche), the two artists clearly share the common origin of their preoccupations. As the American reaches out to the dark stars, antediluvian past and other dimensions, the Polish gothicist looks inside and finds terror "not of Germany, but of the soul" (Poe, 1984, p. 129). Consequently, Lovecraftian protagonists seek the understanding of the hidden mechanics of the world they inhabit, be they genetically, cosmologically, or historically regulated, while Grabiński's characters examine the limits and principles of psychological, emotional and creative power. The obsessions they suffer from are at once life-threatening and life-defining, fuelling investigations which are always already failed, but whose failures mediate and sustain the spectral half-life and the "extended shriek" of Poe's labyrinthine prose. 


\section{References}

Bloom, H., \& Hobby, B. (Eds.). (2009). The labyrinth. New York: NY: Blooms Literary Criticism.

Derrida, J. (1997). Of grammatology. Baltimore, MD: Johns Hopkins University Press.

Grabiński, S. (1931). Książę fantastów (E. A. Poe). Studium literackie. Lwowskie Wiadomości Muzyczne i Literackie, 3, 1; 4, 1-2; 5, 2-3.

Grabiński, S. (1993). The dark domain. Sawtry, UK: Dedalus.

Grabiński, S. (2012). Wichrowate linie (Utwory rozproszone). Kraków, Poland: Agharta.

Joshi, S. T. (1996). A subtler magick: The writings and philosophy of H.P. Lovecraft. Berkeley Heights, NJ: Wildside.

Joshi, S. T. \& Schultz, D. E. (Eds.). (2001). An H. P. Lovecraft Encyclopedia. Westport, CT: Greenwood.

Lovecraft, H. P. (1973). Supernatural horror in literature. New York, NY: Dover Publications.

Lovecraft, H. P. (1999). The Call of Cthulhu and other weird stories. New York, NY: Penguin.

Miéville, C. (2003, February 8). Trainspotting: China Miéville bemoans the dearth of translations of Stefan Grabinski's pioneering horror fiction. The Guardian. Retrieved from https://www.theguardian.com/books/2003/feb/08/featuresreviews.guardianreview20

Poe, E. A. (1984). Edgar Allan Poe. Essays and reviews. New York, NY: Library of America.

Poe, E. A. (2011). Edgar Allan Poe: Collected works: Stories and poems. San Diego, CA: Canterbury Classics.

Veel, K. (2003). The irreducibility of space: Labyrinths, cities, cyberspace. Diacritics, 33(3-4), $151-172$.

Wilczyński, M. (1992). Supplementing the abyss-H. P. Lovecraft and E. A. Poe. Studia Anglica Posnaniensia, 24, 159-168.

Wilczyński, M. (2008). Secret passage through Poe: The transatlantic affinities of H. P. Lovecraft and Stefan Grabinski. Studia Anglica Posnaniensia: International Review of English Studies, 44: $531-538$. 


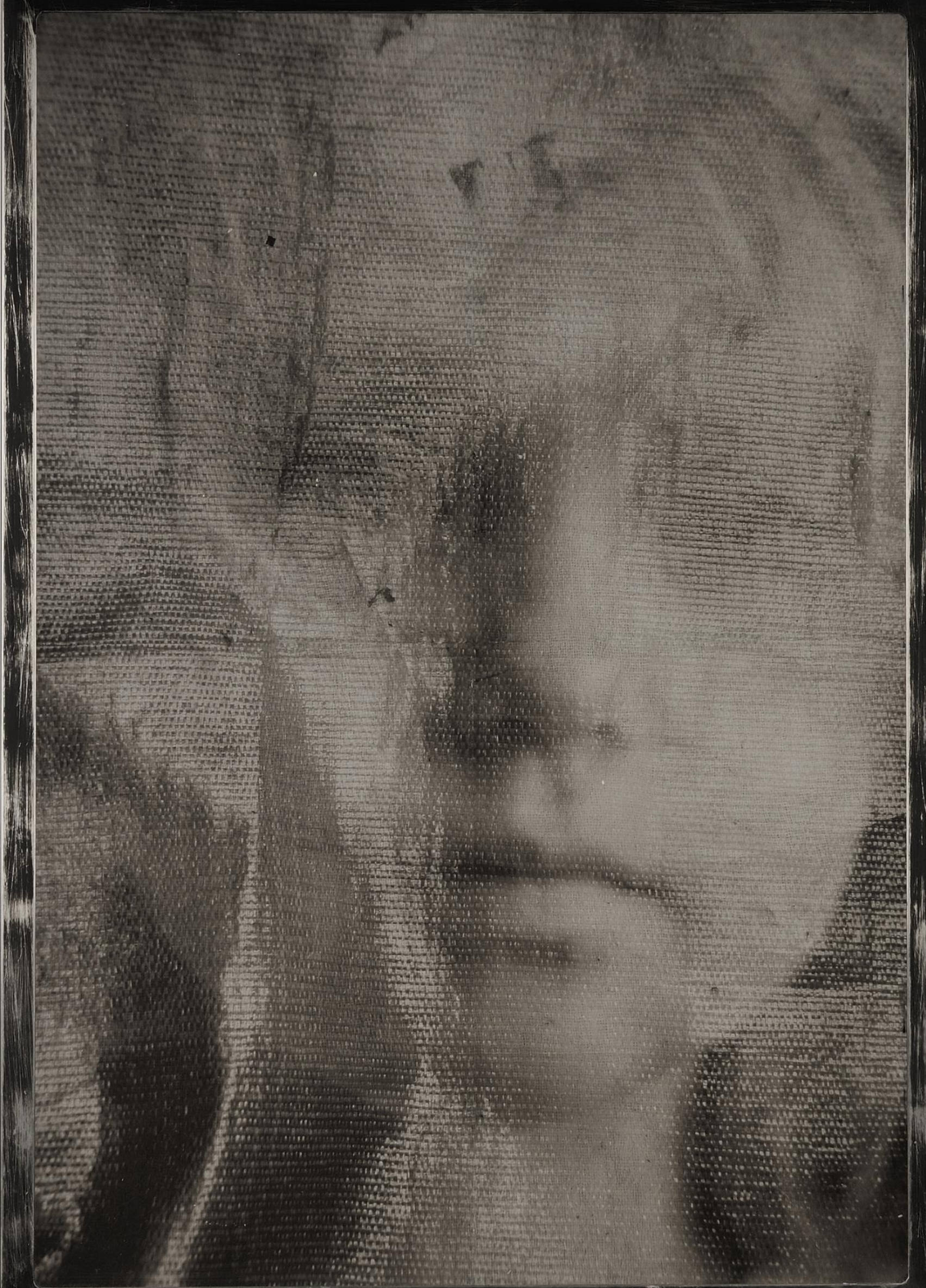


Anna Kola, Untitled, glass, transfer paper, 59x41 cm, 2010 


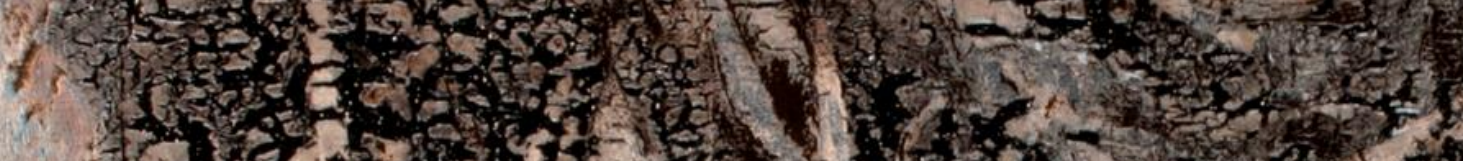

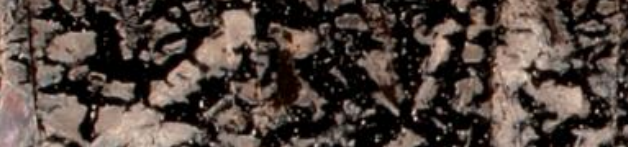

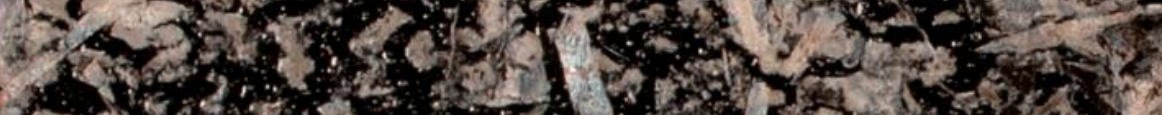

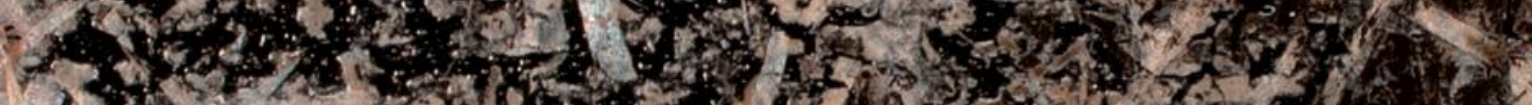
2.

$\mathrm{s}^{\mathrm{N}}$

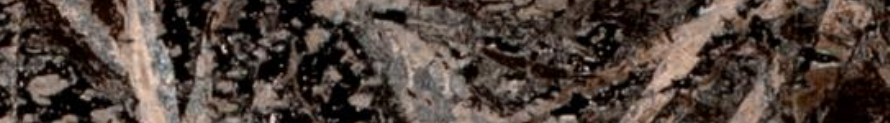

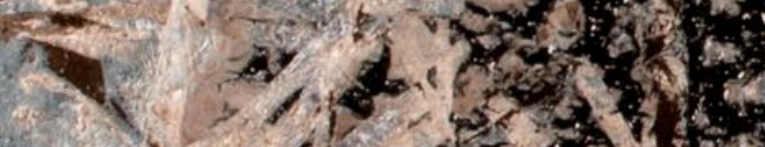

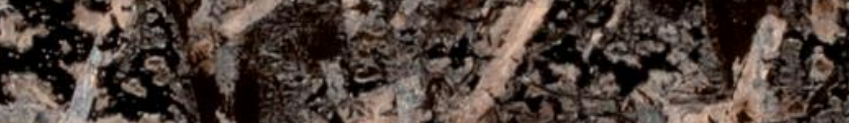

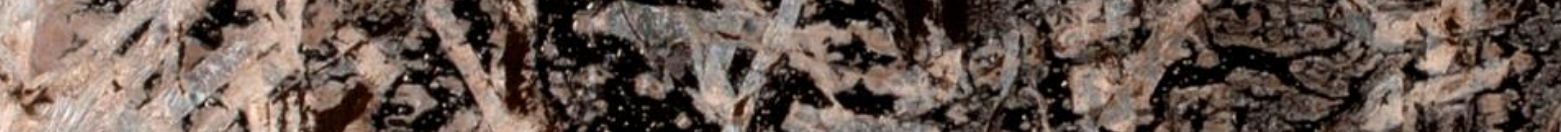

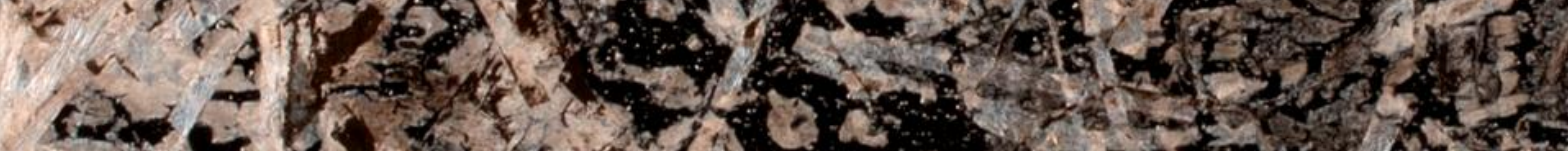

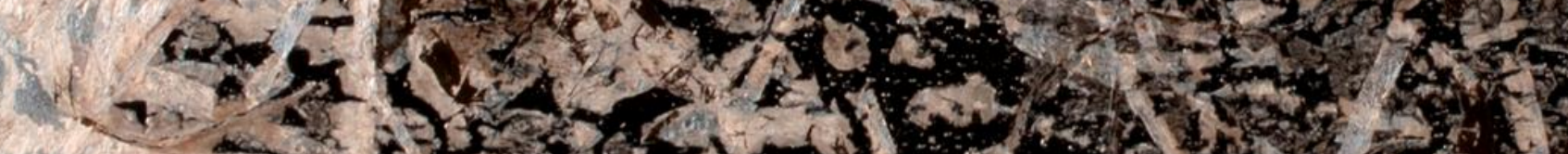

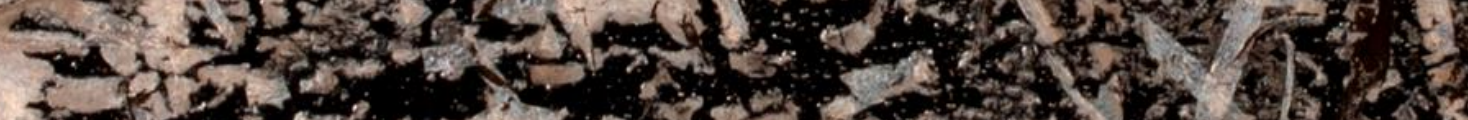

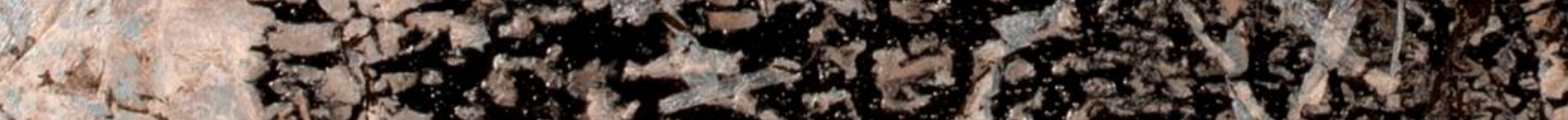

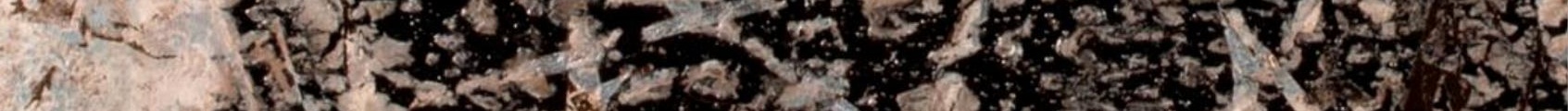

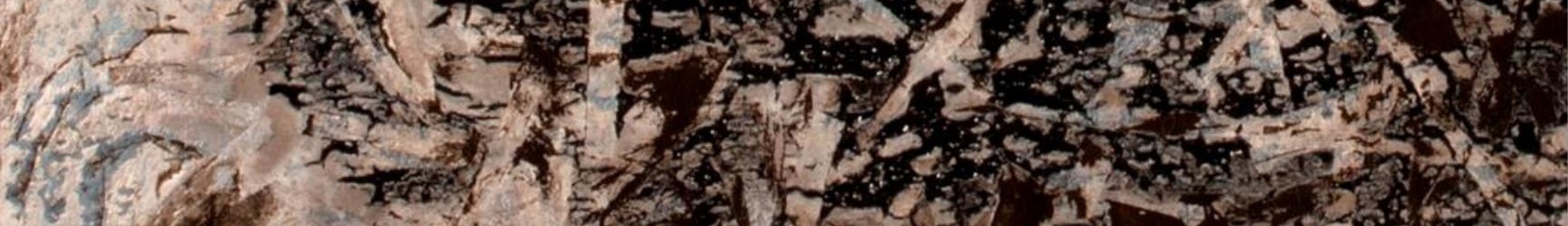

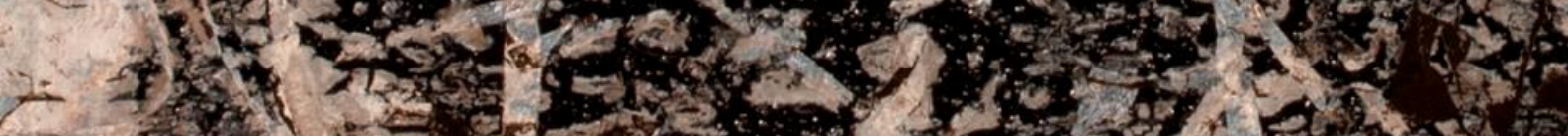

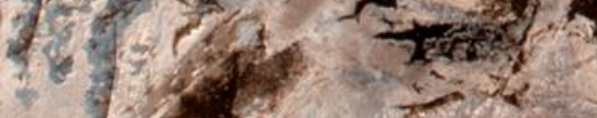
ti $y_{2}$

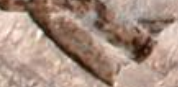
warle.

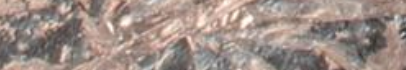
HEVIEVS

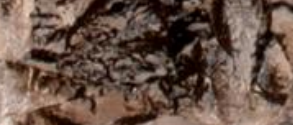

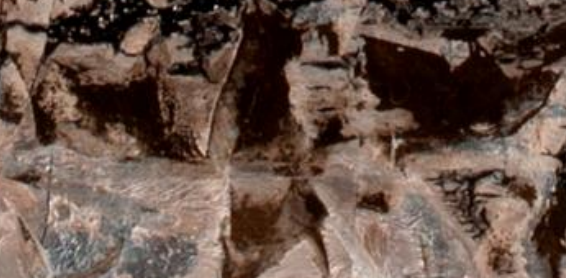

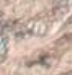
xath artants at<smiles>[111InH]</smiles>
cho 
Anna Kola, $\boldsymbol{K}-\boldsymbol{I I I}$, steel, fused glass, aluminum foil, 50x50 cm, 2009 (fragment) 


\title{
Of Maps and Monsters: \\ A Discussion of Being (Non)Human, or on the Topography of "Monsters" Medieval and Modern by Liliana Sikorska
}

Author: Liliana Sikorska

Publisher: Poznań Chapter Agder Academy

Release Date: 2016

Number of Pages: 65

\section{Mirosława Buchholtz}

Nicolaus Copernicus University in Toruń

Miroslawa.Buchholtz@umk.pl

Received 18 February 2017; accepted 9 June 2017.

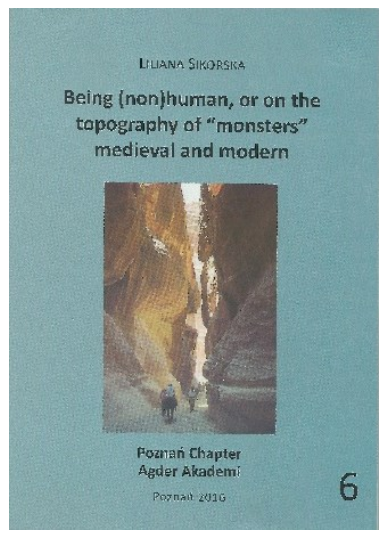

\begin{abstract}
The concept of humanity has taken on new meanings in the era of posthumanist debate. Engaging both prehumanist and posthumanist perspectives, Liliana Sikorska strips away layers of cognitive mappings performed over hundreds of years in Western culture to expose in her recent essay the mechanisms that have exacerbated the East-West divide. While the majority of discussed texts come from medieval and Victorian literature and culture, it becomes obvious to the reader of her book that the issues she explores are still haunting the lives of people and nations worldwide today.
\end{abstract}

Keywords: the East-West divide; human vs. nonhuman; Orientalism; travel writing; maps; the Middle Ages; the Victorian Era.

Several cognitive maps inform Liliana Sikorska's essay, which is at once boldly universal and deeply personal. The most obvious is the juxtaposition of medieval versus Victorian understanding of the world, which spans some 600 years of the Western world's relations with the Orient. However, the allusions and references throughout the book reach far beyond this massive arch, back to ancient geographies, on one hand, and (fast) forward to products of contemporary intellect and popular culture, on the other. The purpose declared 
in the introduction is "to show the mechanisms that contributed to the widening of the East-West divide" (Sikorska, 2016, p. 9) in the Middle Ages and again, though in a different way, in the nineteenth century. Meticulously researched and documented, a selection of literary-cultural texts from medieval and Victorian times serves to demonstrate that far from being a curio cabinet for antiquarians and other collectors, her book addresses dilemmas and debates that are still very much part of globalized lives today. Copious footnotes in Sikorska's book abound in references to recent cultural theories, films, TV series, and political phenomena (including Clinton-Trump and Brexit debates) that mirror or exemplify past conflicts. Thus our present is exposed in Sikorska's essay as a collection of footnotes to the past, which is - as it turns out - by no means dead and gone. Apart from past and present ideologies, the essay is also informed, though not in any partisan manner, by the debate about humanity and posthumanism.

Viewing medieval maps as "discursive weapons," Liliana Sikorska shows that "the development of geography, and so maps, was only possible through the re-iteration of Ancient cosmographic theory re-appropriated through Christianity" (2016, p. 13). Religion indeed made a difference by providing map-making and map-reading with a clear sense of direction and hierarchy. Sikorska refers to two specific maps - at once navigational tools and ideological sums of knowledge: the Madaba Mosaic Map (in St. George's Church, Madaba, Jordan) of c. 560 and the Hereford Mappa Mundi (in Hereford Cathedral, UK) of c. 1300. A detail of the former map, admittedly the most notable "detail," is in fact offered in Sikorska's book as a photograph (Sikorska, 2016, p. 10) in addition to a verbal commentary on the significance of the depicted city of Jerusalem. The latter map is discussed on pages 13-16, but not represented visually. What the two maps have in common, despite the distance in time and space, and despite the difference in the materials and artistic techniques employed in their making, is the centrality of Christian imagery, and especially of the Holy Land. Jerry Brotton offers in his book short discussions of both maps, which indeed lend themselves to such comparative remarks (Brotton, 2014, pp. 32-35, 56-59).

Sikorska refers in her study to a whole range of medieval texts, including William Caxton's Mirror of the World (1480) or the imaginary travel writing of John Mandeville. Pointing to their fantastic or at best second-hand quality, she notices that European writing did not benefit at all from the accounts of Chinese explorers, who visited Europe and India "before Europeans ever reached the Orient" (Holt-Jensen, 1988, p. 13 in Sikorska, 2016, p. 15). Medieval Europeans were not interested in "comparing notes" with other traveling people because they apparently sought confirmation of what they already "knew" about the world, rather than new inconceivable data collected by other (and for this reason specious) "races." Despite the possibility of frightening phenomena, the world of medieval cartographers - in the literal and metaphorical sense - was an orderly place. Medieval morality plays and bestiaries quoted by Sikorska illustrate the thesis that in the Middle Ages the enemies of Mankind were first and foremost the World, the Flesh, and the Devil (Sikorska, 2016, p. 17). Bestiaries offered classifications of animals, which, as Sikorska argues, seem to prefigure "the Victorian obsession with categorization, plus the Darwinian mode of systematization and minus the religious element" (Sikorska, 2016, p. 21). 
The staunch belief in the divine plan (Sikorska, 2016, p. 23) allowed medieval Europeans to accommodate a large variety of different "races," clearly showing the privilege of pure breeds, while treating hybrids with "derision and disgust" (Sikorska, 2016, p. 21). Especially maps in their visual forcefullness demonstrate the possibility of relegating the Other to the margins of the known world. On the Hereford Mapa Mundi, the monstrous peoples "fill sub-Saharan Africa. From the North the map shows cave-dwelling 'Troglodites,' a poisonous 'Basilisk,' a race called 'Blemmyes' with 'mouths and eyes in their chest,' and the 'Philli' who 'expose their newborns to serpents"' (Brotton, 2014, p. 58). All the monsters are grouped far away from the center of the map (Sikorska, 2016, p. 21), that is Jerusalem. In addition, they are separated from the rest of the world, as if for the sake of protection, by a thick dark line of a snake-like river.

In the very preface to his book, Brotton dispells the enticing illusion that there is such a thing - even today — as an objective, scientifically accurate or correct map. He argues instead that "maps answer the specific needs of their intended audience" (Brotton, 2014, p. 7), which applies to the oldest petroglyphs as well as to digital maps available on contemporary mobile phones. While Jerry Brotton uses the concept of map as "a graphic representation that presents a spatial understanding of things, concepts, or events in the human world" (Brotton, 2014, p. 7), Liliana Sikorska seems to extend its meaning to accommodate literary texts as well. A larger part of her discussion of the ways in which the East-West relations have been conceptualized consists of an analysis of Guy of Warwick $\left(13^{\text {th }}\right.$ cent. $)$, one of the longest and best-known medieval romances featuring the struggle of the Western world with "Monstrous Races" (Sikorska, 2016, p. 26-37). Sikorska rightly points to the compensatory function of romance writing, which sought to patch up the reality that was far less glorious. Saracen romances asserted the victory of European Christianity "at the time when the foundations of Christendom began to shake with the first and rather fast growing heretical movements, and in the post-Crusade period with the undeniable loss of Jerusalem" (Sikorska, 2016, p. 37). Thus the deepening of the divide between the East and the West seemed to be a side effect of ideological battles fought primarily in Europe.

The ideological context seems comparable over 500 years later when Sir Richard Burton ventures into the Orient. By then Rudyard Kipling had coined the hypocritical concept of the "white man's burden," throwing wide open again the door to imperialist endeavors. Liliana Sikorska focuses on Burton's travels and the resulting travelogue First Footsteps in East Africa (1856), written by an Englishman who was not only "urbane," "educated," and "cultured," but also "truly interested in the East" (Sikorska, 2016, p. 39). Burton's perspective could hardly have been anything but "western, imperial," but his inevitable bias seems to be redeemed by the "desire to translate the East to the West" (Sikorska, 2016, p. 43). From today's perspective, his "reading" and "mapping" of the East, though far more enlightened and sympathetic than the attitudes of Guy of Warwick, are still informed by a staunch belief in the superiority of his own culture. In conclusion to her study, Liliana Sikorska brings the story of the widening divide to the present, pointing to numerous examples of very recent products of Western culture that have inherited prejudice (and pride too) from their antecedents ages ago. In this sense her book successfully combines the scholarly 
discipline with the conversational style of such a "lover's dictionary" as René Guitton's Dictionnaire amoureux de l'Orient, which likewise focuses on the new significance of old concepts in the world of dynamic change. For example, his reading of the Crusades (10951291) and especially his comments on the post-Holocaust perspective on crusading, juxtaposed with George W. Bush's use of the word "crusade" after 9/11 are good examples of an attempt to show the relevance of old stories today (Guitton, 2016, pp. 214, 216).

The selected references to W.B. Yeats's famous poem "The Second Coming" (1921) in Liliana Sikorska's book, though astoundingly relevant to the explored concepts and texts, remain cryptic and hopefully inconclusive. As a subtext of the discussion in Sikorska's essay, the vestigial presence of Yeats's thought is far more awe-inspiring than Guy of Warwick and First Footsteps in East Africa put together. It seems that Sikorska says less than she would like to say about her own idea of the cosmic (dis)order that interested Yeats to such a great extent. It is clear that she has several stories to tell of deep medieval past, relatively recent Victorian past, the present world, as well as the story of her own exploration of the places described by others. Her own story is told in the fifteen photographs from the author's collection. These are mostly images of places and occasionally of people: the author herself and the dedicatee of her book, her friend and colleague from Jordan. Thus the men's world of medieval Crusaders and Victorian anthropologists is counterbalanced - meekly but efficiently — by two female scholars of today who share ideas over the great divide between Poland and Jordan.

It seems difficult for Sikorska to let go of the idea of the "East." There are so many thoughts, afterthoughts, and loose ends that ask to be tucked into the rich tapestry. What follows the conclusion is a postscript, a short note on the travels of the artist Aleksander Laszenko, accompanied by three reproductions of woodcuts he made in the 1930s, depicting scenes from his travels to the East. It is a coda to the whole story, but especially to the photonarrative pieced together from the images shared by the author and documenting her own travels. The reference to Laszenko at the end makes it clear that in more than one sense contemporary travelers retrace the steps of their predecessors, facing comparable joys and dilemmas. Liliana Sikorska chooses to end her story with the brief remark on Laszenko, but the reader feels that this is where she could actually begin, telling another story about ways of representing the East in Polish photoreportage. In fact, such a study already exists. Even though, predictably, Kinga Siewior's book features most prominently the work of Ryszard Kapuściński, the story of Polish travelers with cameras begins around the time of Laszenko, with Ferdynand Antoni Ossendowski and Ferdynand Goetel in the 1920s (Siewior, 2012, pp. 65-111). The abruptness of conclusion and postscript in Liliana Sikorska's essay show that the story, like haunting, has no end. 


\section{References}

Brotton, J. (2014). Great maps. London, UK: Dorling Kindersley.

Guitton, R. (2016). Dictionnaire amoureux de l'Orient. Paris, France: Plon.

Holt-Jensen, A. (1988). Geography: History and concepts. London, UK: Paul Chapman Publishing.

Siewior, K. (2012). Odkrywcy i turyści na afrykańskim szlaku. Kraków, Poland: Universitas.

Sikorska, L. (2016). Being (non)human, or on the topography of "monsters" medieval and modern. Poznań, Poland: Poznań Chapter Agder Akademi. 



\section{Spectral Uncertainties: \\ A Review of Precarity and Loss: On Certain and Uncertain Properties of Life and Work by Tadeusz Rachwal}

Author: Tadeusz Rachwał

Publisher: Springer

Release Date: 2017

Number of Pages: 143

Edyta Lorek-Jezińska ${ }^{1}$ \& Katarzyna Więckowska ${ }^{2}$

Nicolaus Copernicus University in Torun

${ }^{1}$ lorek@umk.pl

2klew@umk.pl

Received 18 Sptember 2017; accepted 28 October 2017.

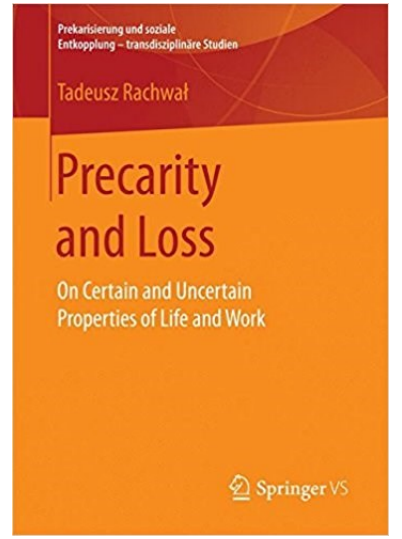

In the foreword to the 2012 edition of Liquid Modernity (first published in 2000), Zygmunt Bauman, one of the key theoreticians of the contemporary, lists "fragility, temporariness, vulnerability and inclination to constant change" as the key features of our times, when the only stable element might be described as "the growing conviction that change is the only permanence, and uncertainty the only certainty" (Bauman, 2012, p. 8; emphasis in original). The metaphor of "liquidity" aptly captures the sense of immanent but uncontrollable change and the ensuing anxieties almost universally experienced at the beginning of the $21^{\text {st }}$ century, a time of fierce globalization, authoritarian populism, rising nationalistic movements, growing separatist tendencies, constant threats of terrorist attacks targeting civilians, impelled migration, and persistently increasing poverty gap. Closely related to economic and political reconfigurations, the sense of change, insecurity and anxiety has been reinforced by the collapse of grand narratives and the loss of faith in the Enlightenment certainties of progress, science and individual identity, described by Jean-François Lyotard already in 1979. The overall result of these transformations is that in liquid modernity life itself has become "liquid," and therefore, as Bauman claims, "precarious ..., lived under conditions of constant uncertainty" (2005, p. 2). 
Precarity seems to have become one of the most frequently used terms to describe the contemporary condition, though in ways which point to various spaces and different aspects of vulnerability that is usually, but not exclusively human. Thus, Judith Butler writes about precariousness as a social and ontological phenomenon and discusses the modes in which vulnerability and the susceptibility to "arbitrary violence" are differently distributed across and between societies (2004, p. xii). ${ }^{1}$ Drawing on the work of Emmanuel Levinas, she defines precariousness as an existential category, through which one recognizes others as beings and is recognized as a being by others, and which inevitably involves facing and possibly taking on the ethical responsibility for another person's vulnerable body. While Butler's focus is on various individuals and groups to whom official discourses deny the right to being precarious - thereby denying them social, legal, or cultural recognizability-Guy Standing describes precarity as a key feature of the precariat, the new class of workers emerging under global capitalism. As presented by Standing, the precariat is a product of increasingly more unequal societies; its members experience severe deprivation and, with little help offered by the state, face the constant risk of falling into the poverty (or precarity) trap (Standing, 2014, p. 7; 2013, p. 10). The precariat are "the first emerging class to be losing all forms of rights - civil, cultural, social, economic and political" (Standing, 2016, p. 29), in effect becoming denizens rather than citizens, ${ }^{2}$ whose lives are dominated by "insecurity, uncertainty, debt and humiliation" (Standing, 2014, p. 7). Significantly, though Standing reserves the term "precariat" to designate the new working class, he also describes some general and global processes of precariatization, such as the inability to command one's time, that produce "the precariatized mind," which is "enervating and ultimately depressing because one cannot feel in control" (2013, p. 6).

Uncertainty, precarity, loss, and hesitation are the crucial themes of Precarity and Loss: On Certain and Uncertain Properties of Life and Work by Tadeusz Rachwał, which can be described as an attempt to understand precariat (Rachwał, 2017, p. viii) and to represent the many forms of contemporary precariousness experienced by "individuals orphaned from the care of the modernist fathers" (p. vii). In Rachwal's book, precarity and loss cut across many fields and texts, affecting the way of thinking about different "properties of life and work." The introduction already addresses a whole range of issues, starting from precariat and the uncertainties of employment, flexibility of life and labour and their destabilization, fragmentation as well as nomadism and ending with the concept of "the loss of loss" or spectral uncertainty. As the author admits, "this book is in a sense a hesitant book. It is also uncertain. Its hesitations result from the precarious nature of certainty itself, of the precariousness of confidence which, as we know, can always be lost. It approaches certainty with caution, wavering over making choices or certain decisions" (p. ix). Such a book is both

\footnotetext{
${ }^{1}$ In the context of the $21^{\text {st }}$-century uncertainties listed above, it should be noted that the essays collected in Butler's Precarious Life were all written "after September 11, 2001, and in response to the conditions of heightened vulnerability and aggression that followed from those events” (Butler, 2004, p. xi).

${ }^{2}$ Standing explains that "denizen" is "a medieval term used to describe those who on entering a town were given a more limited range of rights than the town's citizens" (2016, p. 29).
} 
devoted to and itself requires "slow reading," the reading that cannot be counted on to produce immediate results, that will lead the reader apparently astray, and then surprisingly return to its course to lose it again. In fact, losing the track is its intended strategy. Precarity and Loss demands from the reader time and readiness to abandon the "optimization of gain" (p. ix) and risk the loss of the thing one gains by promise - by being promised to finally and slowly reach the destination: "I will, I promise that I will, slowly arrive at the vicinities of precarity in the course of this text though, at the same time I will, after Nietzsche, go aside and take time, attempting, also at the same time, not to quite lose it" (p. ix).

Hesitation is important to Rachwał's project because the "experience of undecidability" is what "brings in, inevitably, the question of ethics, of choice hidden in the very notion of hesitation" (p. x). Accordingly, adopting the strategies of slow and hesitant deconstructive reading, the author explores various facets of precarity and uncertainty related to, among others, space, time, truth, authority, and responsibility, and examines the precarious dimensions of life, work, labour, writing, and reading. A key category in these analyses is loss, which is approached here as denoting a "loss of property" not only in the economic, but also in the epistemological sense. Reminders of the uncanny relation between economy and epistemology return at various points throughout the book, beginning with the coupling of Standing's analysis of global capitalism with Butler's inquiry into ethics, identity, and injurability. Precarity and Loss does not let its readers forget about the profoundly material parameters, corporeal or economic, of being and its descriptions, while emphasizing the power of loss that underlies these categories. In effect, Rachwat proposes to read loss in terms of spectrality, as "a spectre without origin" (p. xiv), thereby highlighting the uncertainty that permeates contemporary life and thought, and presenting it as constitutive of "the human."

Precarity and Loss: On Certain and Uncertain Properties of Life and Work is composed of an extensive introduction outlining the scope of the book and five chapters examining various discourses on uncertainty in order to assess and represent the possibilities of escaping what may be provisionally differentiated into material precarity and existential precariousness. Each of the chapters addresses a different set of questions - of what, how, why, where, and who - thereby ordering the content according to the inquiries that are basic in information gathering and problem solving. The first chapter poses the question "What?", predominantly with regard to loss as well as time, and comments on two major issues: perishability and the idea of having time. The focus in the second chapter is on "How?", particularly on how time and work are used, and on the relations between economy and aesthetics, illustrated by the discussion of, inter alia, John Ruskin's discourses on work and art, or Oscar Wilde's notion of individualism. The third chapter revisits the uncertainty in / of Descartes' writing and examines "the threat of there being nothing instead of something" that Rachwał sees as standing "behind the founding question of metaphysics asking 'Why is there something instead of nothing?" (Heidegger as cited in Rachwał, 2017, p. 51). The fourth chapter is dedicated to the question "Where?" and investigates the spaces, physical and conceptual, that answer to and oppose precarity and 
precariousness. The final chapter is a manifesto of sorts which, by addressing those subjected to precarity and precariousness, performatively re-constitutes them as subjects, turning them into a collectivity of "the Precariat; or All Together Now" (p. 105).

The first chapter, whose preoccupations centre on aspects of perishability and time, begins with references to Leonard Cohen's novel Beautiful Losers, whose protagonists, the A- $\mathrm{s}$, an imaginary, almost extinct Indian tribe, become the embodiment of absolute loss. They illustrate "the idea of life, or living, without loss, perhaps without possessing the idea of losing" (Rachwał, 2017, p. 1). But because of this, because of the impossibility of ever succeeding, they have lost their "whatness." By referring to Jean Baudrillard's commentary on the imaginary materiality of Indian reservations and factories (2007, p.19), among others, Rachwał sees Cohen's A-s as also the embodiment of perishability: "What this simulation hides is that we are all the $\mathrm{A}-\mathrm{s}$, almost extinct Indians, losers who organize work and production to hide our own 'perishability' by way of reducing its inevitability. Perishability may thus be read as a practice of 'no-whatness' something which brings to mind the 'no-placeness' of utopia . .." (Rachwał, 2017, p. 3). Perishability is discussed primarily in reference to Quentin Meillassoux's After Finitude (2008), where it is juxtaposed with contingency, but numerous other books and writers are mentioned in the discussion (inter alia Zygmunt Bauman, Marek Kwiek, Guy Standing, Jean-Luc Nancy, Raoul Vaneigem). The second part of the chapter focuses on the concept of time- of having time. The starting point of the discussion is a commentary on tertiary time and tertiary society - the terms used by Standing to describe the disappearance of the clearly marked boundaries between leisure and work, the result of which, as Rachwał argues, denotes not only the increase of precariousness but perhaps more importantly, "points to a more general condition of uncertainty which may be called the loss of 'whatness' of time along with the very possibility of its wasting, or losing, pure and simple" (p. 9). Rachwał's discussion of time, its loss or the possibility of its appropriation and possession, ordering and "timing" time, breaking it into a series of nows is primarily based on a selection of Heidegger's texts. Attempts at re-creating the past, reconstructing or recapturing it illustrate the strategies of miming what is deficient about time, as "lack is translated into loss which is itself translatable into the 'pastness' of time that may be 'had', or regained, by history" (p. 14). To abate loss, time is also "rigidified" in the stillness and permanency of tombs, architecture, paper, writing, which become the "work of mourning" (p. 16). Thus, the only time we might have is the mimetic time, its weakened double, managed by the "economies of compensation" (Derrida as cited in Rachwał, 2017, p. 18), which we delude ourselves to be able to possess and spend at will.

The second chapter asks the question "How?" and explores the uses of time and work, and thus also the possibilities of having a good life, through the concepts of poiesis, plasticity, and contingency. The author examines the attempts at limiting uncertainty, as presented in an array of critical and literary works, beginning with "the ways in which contingency may be dealt with in terms of the poetical, the realm which both escapes historical ordering and attempts to, paradoxically, extend history so as to diminish its seizing grasp" (Rachwał, 2017, p. 22). The "uses" of art-the aestheticization of contingency, labour, or 
economy - is the key issue discussed in this chapter, starting from the work of Simon Critchley and his examination of the relations between finitude and contingency, as well as fact and fiction, in particular his delineation of "facticity of fiction, and thus also of contingency of facticity" which may make it possible to think of a world "in which uncertainty does not stand in opposition to any absolute certainty of the permanence of being" (p. 23). The connections between life and art are further explored with reference to Jacques Rancière's concepts of politics and aesthetics, and his notion of dissensus which reveals the contingency of a particular social arrangement, or what Rancière calls the " "partition of the sensible' in which art does not simply transform messages, but partitions spaces and times defining ways of being together or apart" (p. 23). It is in this context that Rachwat reads Oscar Wilde's project of "oppositional" aestheticism and Individualism as an attempt of getting rid of both the precariat and precariousness (p. 25), and discusses William Morris's proposal of "work-pleasure" as a dissensual activity (pp. 26-27). 19 $9^{\text {th }}$-century discourses on society, work, and art offer some enduring answers to the question of how one should work, labour, and live - aesthetically according to Wilde, pleasantly and industriously according to John Ruskin, or, as the analysis of Charles Dickens's Hard Times proves, in a disciplined and disciplinary manner. What underlies most of these concepts, as Rachwał states, is the "annexation" of work and nature by labour, which can be traced back to John Locke, in whose writings the ability to work is intricately bound with property and possession not only of one's self or body, but also of one's land, and in which "being" is transformed "into having through labour" (pp. 37-42). The chapter finishes with a return to Heidegger's notion of dwelling to read it through the Greek idea of poiesis and to argue for the "originary uncertainty of poetic dwelling" which "questions the security of the dwelling place, of broadly understood home which turns out to be an inevitably haunted place, a place which is open to the contingent spirit of the undecidability of language, of its always provisional status" (p. 45).

Chapter 3, "Why? Something, Nothing and (Descartes') Uncertainty" starts with Heidegger and Hamlet. Addressing the Heideggerian query of "Why are there beings at all instead of nothing?"(Heidegger as cited in Rachwał 2017, p. 52), Rachwał develops his commentary on consequences of questioning beings and questioning also the very act of questioning itself (Heideggerian "Why the Why?"). The fact that this question is additionally "hamletized" by Heidegger is the beginning of reflections on the nature and possibility of choice which in a way the "why?" question eliminates. Hamlet, who is suspended in his inability to choose, belongs to the pre-political world in which such a sovereign choice based on the presence of the sovereign identity, as Rachwał argues, referring to Carl Schmitt's analysis of Hamlet and its embedding in the political situation of the times of its creation, is not yet possible, for he "does not know nothing" (p. 55) and Hamlet's "question, and choice, can be made only by one holding the power to except" (p. 56). The power to except and relegate to nothingness is considered in relation to Agamben's concept of homo sacer and "bare life" and other implications of exteriorization and our vulnerability to exclusion (e.g. Deleuze and Guattari). What emerges out of this discussion is the very plasticitymutability — of being or being as mutability, discussed extensively in relation to Catherine 
Malabou's writing, the category that seems to go beyond the choice between being and nothingness and beyond death. Following the strategy of "going aside and taking time," Rachwał reflects on how the field of translation is affected by the category of loss, which comes to replace lack (Slavoj Žižek) and how its authenticity is linked to the precariousness of both the authority of the original and the position of the translator as a copier (p. 65). ${ }^{3}$ In the last part of the chapter Rachwał moves to the third element of the title, Descartes, whose "cogito ergo sum" "has been historically marked as one of the beginnings of modernity (along with its faiths in permanence and certainty)," to argue that "what it in fact establishes is a certain dynamism of constant deference of the uncertain as constitutive of the fragile position of the thinking subject" (pp. 75-76). In order to preserve certainty and offset uncertainty, which are the aims Descartes sets to himself and human beings in general, what is required, it seems, is a constant erasure of the past: "Since more or less everything seems to be erroneous, certainty needs a new beginning which erases all the traces of the old, a writing under at least double erasure which erases the erased, perhaps a flood or deluge of sorts after which the creation will be repeated. This repetition, importantly, must not remember the old, must not be able to refer the old as lost, not even as a lost paradise" (pp. 80-81). Rachwał's extensive critique of Descartes' certainty concludes with Žižek's commentary on the loss of loss, which posits the possibility of reading loss in positive and productive categories, as creating "a space of incessant reconfiguration of the world" (p. 87).

The question of "Where?" is addressed in Chapter 4, which focuses on the relations between places and spaces, or more specifically on what Rachwał calls "spacing places," and discusses the ideas, projects, books, writers, and artists that make such spacing possible. "Spacing places" is both "a strategy of rethinking space" (p. 95) and "an idea that questions, among others, the scope of finitude" (p. 92), which the author juxtaposes against "placization," that is, "a reduction of space to place" that makes the former finite (p. 90). This reduction is a crucial aspect of the power of capitalism (p. 90), hence questioning finitude is also a search for spaces, physical, architectural and conceptual, that oppose the system. Unlike scholars such as J.K. Gibson-Graham, ${ }^{4}$ who look for this kind of spaces outside capitalism, Rachwał argues against the illusion of exteriority and claims that it is "within capitalism that the allegedly new enterprises and spaces should be built" (p. 90). The examples of such spaces discussed in the chapter include Constant Nieuwenhuys's New Babylon, a radical, anti-capitalist project of nomadic urbanity and identity which "slightly blurs the division into the made and the maker" and the conventional division of labour (p. 92); Yona Friedman's concept of mobile architecture, most famously embodied in his project of The Spatial City, which gives a new kind of mobility to the inhabitants (p. 101); or, on a more abstract level, Rosi Braidotti's "nomadic eco-philosophy of belonging” (p. 93). In such places, spacing functions in a manner similar to that described by Jean-Luc Nancy as

\footnotetext{
${ }^{3}$ The concept of authenticity is associated with precariousness in a variety of contexts which Rachwał further discusses: Barthes' intertextuality, Bloom's anxiety of influence, or Baudrillard's reproducibility of all objects.

${ }^{4}$ Interestingly, this is a pen name adopted by feminist economic geographers Julie Graham and Katherine Gibson, which provides another area of uncertainty by questioning the conventional approach to the figure of the Author.
} 
opening "a new horizon of unheard-of identities" (Nancy cited in Rachwał, 2017, p. 7) and producing places of an almost "poetical" dwelling in an uncoordinated environment. While the utopian projects of Friedman and Constant may seem "naïve ways of mapping and orienting the world," they also, as Rachwał argues, provide spaces where "loss is not relationally attached to gain, or achievement," and whose dwellers may "unlearn the abstract" so as to learn "what it really means to love thy neighbour" (pp. 103-104).

The questions of neighbouring and neighbours, or of "being-building-neighbouring" (p. 106), occupy the central space in the final section of the book which, as a way of concluding, considers the "who" of the precariat and its possibilities of action. The chapter juxtaposes neighbouring, considered as Heideggerian "dynamic kind of poetic dwelling" and Derridean hospitality of "neighbours awaiting neighbours as guests" (p. 106), against the notion of individuality which Rachwał, following Friedrich Hayek, sees as "a selfcliquing care for the self in which building can be only seen as . . extensions of the defensive measures and means" (p. 107), as a closure, not an opening. Referring to the work of Alain Badiou and Luce Irigaray, the chapter introduces the concept of "love" into the notion of collectivity in order to reconfigure the "we" of "the precariat" into "a kind of togetherness in which lack is not a sign of a precarious position, a sign of loss, but an attitude which is lovingly, though perhaps painfully assumed" (p. 109). This attitude is based on the acceptance of ambivalence and uncertainty, so that the rise of the precariat may become "an opening of the threshold, of the space in which we begin to re-think difference and togetherness, and to realize that the complex senses of us and them need not be normalized, and that we and them may, and must, lovingly mix at the thresholds of what we are" (p. 113). As Rachwał argues, it is this ambivalence, "this potential to transform and change," and "this spectre of changeability in non-belonging" that make the precariat a precarious and "dynamically plastic kind of being" (p. 114). In the end, "We the Precariat" constitutes a threshold and "a somehow naïve world governed by the law of the real which . . is the law of love" and by an economy "which will have left the economy of loss and debt, as it were, at its home" (p. 114).

Tadeusz Rachwał's Precarity and Loss is concerned with what to many people has become an everyday experience of the $21^{\text {st }}$-century life and work. It is an important book for its ability to combine this lived experience of uncertainty with reflection on its various implications, which — while they perhaps cannot reduce the anxiety related to precarity — can make the experience understandable and productive, creating space, or spacing places, for a new kind of collectivities. One of these productive implications of Rachwal's book is finding a way out of the necessity to know for certain, of writing and acting without having to know, which might be seen as a response to Bauman's description of modernity as anxious and uncertain. In the preface to the 2012 edition of Liquid Modernity, with which we have begun our review, the sociologist returns to Antonio Gramsci's concept of the interregnum as the period when "the old is dying and the new cannot be born" (Gramsci,

\footnotetext{
${ }^{5}$ Rachwał refers here to Michel Serres's declaration from The Natural Contract that "There is nothing real but love, and no other law" (p. 50).
} 
1978 , p. 276) to describe the early $21^{\text {st }}$ century as the time "when the old ways of doing things no longer work, the old learned or inherited modes of life are no longer suitable for the current conditio humana, but when the new ways of tackling the challenges and new modes of life better suited to the new conditions have not as yet been invented, put in place, and set in operation" (Bauman, 2012, p.vii). Bauman's acknowledgment of the suspension of time, of its tense hesitation, is also a call for a different strategy of thinking, writing, and doing things, to which Rachwał's book responds, though necessarily "only with a certain uncertainty, hesitantly" (Rachwał, 2017, p. ix), by making "spectral uncertainty ... one more 'property of life', both certain and uncertain, a property which, like life, cannot be protected by a "now' which testifies to its simple presence" (p. xv).

\section{References}

Baudrillard, J. (2007). Symbolic exchange and death. (I. H. Grant, Trans.) Los Angeles, CA: Sage Publications.

Bauman, Z. (2005). Liquid life. Cambridge, UK: Polity.

Bauman, Z. (2012). Liquid modernity. Cambridge, UK: Polity.

Butler, J. (2004). Precarious life: The powers of mourning and violence. London, UK: Verso.

Gramsci, A. (1978). Selections from the Prison Notebooks of Antonio Gramsci. (Q. Hoare \& G. Nowell-Smith, Eds.). London, UK: Lawrence \& Wishart.

Lyotard, J.-F. (1984). The postmodern condition: A report on knowledge. (G. Bennington \& B. Massumi, Trans.). Manchester, UK: Manchester University Press.

Rachwał, T. (2017). Precarity and loss: On certain and uncertain properties of life and work. Wiesbaden, Germany: Springer VS.

Serres, M. (2003). The natural contract. (E. MacArthur \& W. Paulson, Trans.). Ann Arbor: University of Michigan Press.

Standing, G. (2013). Tertiary time: The precariat's dilemma. Public Culture, 25(1), 5-23.

Standing, G. (2014). The precariat: The new dangerous class. London, UK: Bloomsbury.

Standing, G. (2016). The precariat dilemma. In Y. Cooper (Ed.), Changing work: Progressive ideas for the modern world of work (pp. 25-31). London, UK: Fabian Society. 


\section{A Book Review of Duchologia polska. Rzeczy i ludzie w latach transformacji by Olga Drenda}

Author: Olga Drenda

Publisher: Wydawnictwo Karakter

Release Date: 2016

Number of Pages: 256

\section{Marek Jeziński}

Nicolaus Copernicus University in Torun jezmar@umk.pl

Received 10 September 2017; accepted 28 October 2017.

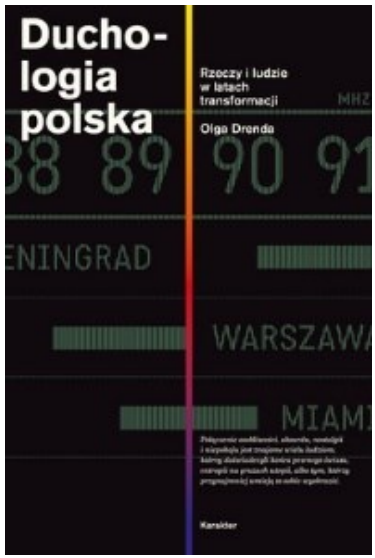

1.

The book by Olga Drenda Duchologia polska. Rzeczy i ludzie w latach transformacji, whose title can be rendered in English as Polish Hauntology: Things and People in the Transformation Period, is a kind of anthropological travel in time: to the past that is not too distant, that is still remembered, and still visible in Polish streets. The work covers the "haunted time" between 1987 and 1994, when Polish society underwent significant social, cultural, economic and political changes, joining liberal democracies and liberal free market economies. Drenda depicts several phases of the transition, related to the ineffectiveness of the socialist system, political changes towards democracy (with the Round Table Agreements and semi-free elections of 1989 as the landmarks of this process), and the gradual adaptation to a new social system. Focusing mostly on the changes in the cultural sphere, the author argues that the process of adaptation was over in 1994, when the copyright law was introduced in Poland.

Drenda uses the concept of "hauntology" to depict the process of people's trying to come to terms with the new world and its complexity. In the book Specters of Marx by Jacques Derrida (2006, first published in 1993; 2008), the French philosopher refers to the presence of memories, fragments of the past events, or the occurrence of themes from the past in 
contemporary cultural practices. This approach has been debated and discussed in numerous books and comments, for example, in the works by Colin Davis $(2005,2007)$, Fredric Jameson (2008), Nicholas Royle (2003), or in the texts gathered in Maria Pilar Blanco and Esther Peeren's The Spectralities Reader: Ghosts and Haunting in Contemporary Cultural Theory (2013). In some of these analyses, hauntology is viewed as a liminal phenomenon in between certain stages, having an incomplete, indefinite character. This aspect is discussed by Drenda in her book.

The past as a phenomenon "haunting" the present is a motif found in every culture and in every historical period: this primarily refers to tradition and the way in which the elements of culture from the past define the present. This is one of the bases on which a group culture is formed: a group's identity is perceived in terms of continuity necessary to maintain the main values defining the specific character of a given society. As Simon Reynolds in his widely acclaimed book Retromania (2011) points out, such a recurrence of the past in the present, "visited" by the ghosts of the bygone years is particularly visible in the first decades of the $21^{\text {st }}$ century. Reynolds calls the present times in pop culture "the Re-decade" characterized by intentional and frequent references to the past in popular music and the more or less creative ways of using bygone inspirations by contemporary artists. In this perspective the past becomes the main paradigm through which people interpret today's culture. Being embedded in the past and in tradition is typical for human societies: individuals and groups in their cultural practices try to reproduce the social order that gives them stability and predictability in everyday life.

As Nick Couldry points out in Inside Culture: Re-imagining the Method of Cultural Studies (2000), to describe and capture the changes of the cultural system, the system itself or at least its parts must be "closed" and the cultural phenomena related to the change completed. Understandably, culture is not a measurable phenomenon; it can be examined by researchers by decoding a spectrum of interconnected elements interwoven into cultural narratives. In her book, Drenda shows this period of Polish history as a closed and already completed transformation of fundamental importance. The period between 1987 and 1994 is the time in which the subsequent stages of the fall of the Polish People's Republic's (PRL) political system (something that seemed impossible only five years earlier) took place and the new patterns of behaviour emerged. Importantly, the political transformation that was experienced in Poland was a process of continuous adaptation and assimilation of cultural patterns. It turned out, however, that the new system was different from the one the majority of Poles expected and dreamed about during the decades of socialist power: real life in capitalism was mainly reduced to struggle with everyday life difficulties. In other words, using Max Weber's concept, systemic modernization took place in Poland, and today one can experience its testimonies or remnants as ghostlike - hauntological—afterimages.

The period between 1987 and 1994 is still present in the cultural practices of Polish people: the references to the 1980 s and 1990 s are, to some extent, the essential components of the group identity dominant in the first decades of the $21^{\text {st }}$ century (due to the fact that the current adult generation was growing up in these decades), following the cultural retro or 
vintage trends prevailing in Europe nowadays. Tradition is generally attributed with positive values and supplemented with nostalgia, through which the past is consistently mythologized. The main value of Drenda's book is that it shows the reader that the past, to which contemporary culture constantly refers, may be disturbing, and that the "haunting" of the present is not and cannot be understood only in positive terms. Looking from this perspective, the past is a source of anxieties, fears, and understatements. The book's title Polish Hauntology emphasizes that remembering the past is not a pleasant journey in time, but an attempt to deal with what in today's culture appears to be a set of disruptions, which "hurt" and still require proper explanations.

The book by Drenda is an attempt to "deal" with such ghosts and fears of the transformation period and its complexity. The author assumes in the "Introduction" (Drenda, 2016, pp. 7-8) that to overcome such anxieties one needs to tell the others about the phenomena that cause fear. Additionally, as the author notes, "memories of the $80 \mathrm{~s}$ and $90 \mathrm{~s}$ are full of disturbances. Of course, this is their very nature, prone to forgeries and deceptions - but why is there so much of technology-driven horror in generational memory? Is it because we remember a picture full of 'ghosts,' afterimages, and ruptures. . .?" (Drenda, 2016, pp. 7-8; my translation).

2.

The past is generally remembered as a set of colourful memories captured on postcards and pictures/photos from the era. Such categories as "pictures"/ "photographs" and "afterimages" organize the argument in Drenda's book: they are not only material artefacts and non-material images in people's minds that evoke memories and determine their strength, but also the means through which Drenda segregates, arranges, and categorizes the materials. Looking at photos, posters and postcards - and all visual documentation in generalDrenda tells a story, which sometimes strays from the path of anthropological study and takes the form of a reportage about the search for the lost world, which exists next to us. Its habitats can be found in the archives of public institutions, but also in people's memory and home drawers, housing memorabilia. The subsequent chapters of Drenda's book are devoted to various hauntological phenomena: urban spaces (the chapter "Krakowskie Przedmieście is flooded with sunshine"); the housing styles (the part "Cosily"); the design of everyday objects and toys (the section "The Bear who lost to the Frog"); electronic equipment and the distribution of the media containing music and feature films (the fragment "Stereo Super Quality"); the art of covers and posters, which was developed in the earlier period, but in the era of transformation was replaced by ineffective cheap graphic design (the chapter "Foil-wrapped butterflies"). Further chapters comment on the "invasion" of aggressive advertising in the public sphere and in the media (the section "A girl

\footnotetext{
${ }^{1}$ All chapter titles in English with the exception of "Stereo Super Quality" are my translation.
} 
in an advertisement adds prestige and elegance"); a growing fascination with esoteric issues - books, magazines and television programmes about the "hidden dimension" of reality (the part "Purple turning white"); and finally, Poles' fascination with the Western lifestyle and products that began to be available on the Polish market, as the "Western" label was supposed to guarantee their superior quality (the chapter "Michael will eat cheesecake with relish").

Drenda's book should be praised for its documentary content: the author evokes many anecdotes, stories, and recollections told by people who lived in the realities of the transformation period in Poland and the foreigners travelling around this part of Europe. This aspect of the book is particularly valuable: people who remember the living conditions during that period may recall the "surrealism" of real socialism and the precarity of the transition phase, and probably many readers often thought: "oh, really indeed! That's how it was. .." when reading the book. For the young people Duchologia polska may be an important lesson in the history of their parents' and grandparents' generations. The Polish People's Republic had an inefficient economic system and today's stories about it focus on the systemic curiosities and absurdities. It must be remembered, however, that the reality Poles had to live in was neither surreal nor fun. It is worth looking at such curiosities from that time as curtains in shop windows, foreign currency stores, local bazaars as the places of basic products supply, or physical space shortage in flats, buildings and pavilions which were inadequate to human needs. One can add the poor aesthetic quality of books, tapes, and magazines covers of the transformation period. The anecdotes concerning these phenomena abound in the book and are attractive for a reader.

The stories spun by Drenda, then, expose the specificity of the times of the Polish People's Republic and the paradoxes of its functioning. Ironically, although its political system was negatively assessed by the majority of Poles, it introduced into social and cultural life several phenomena that define cultural identity of today's Poland. One faces a peculiar contradiction here: the citizens who lived in tough conditions and regularly criticized the authorities were characterized by outstanding creativity, supported by-which is extremely interesting - the media institutions controlled by the politicians. In response to the inadequate supply in shops, ineffectiveness of trade, difficulties with obtaining objects of everyday use (kitchen equipment, furniture and interior furnishings, clothes), articles in the magazines and journals controlled by the communist party were published, containing advice on cooking, tailoring, the construction of furniture or recycling. The political system could not officially admit its own inefficiencies and general ineffectiveness, and at the same time, it showed its citizens that they could overcome the difficulties by themselves. The beginning of the 1990s was an obvious qualitative breakthrough: Western culture and its products appeared on the market, which began to be organized on the supply and demand basis. The changes were accompanied by the emergence of large-scale unemployment, a decline in real income and a significant poverty of some social groups, which was described by sociologists in terms of social exclusion and underclass. Therefore, only a small number of Poles could afford full participation in consumption (the possibility of 
buying goods available on the market) as the purchasing power of most citizens was drastically limited. This resulted in many cases of abuse, scams, scandals, and "one-season" careers in business and politics; the period is remembered by many people through these negative phenomena. Tricking the system by citizens was a semi-acceptable practice in the socialist times; after the turn of 1989/1990, social acceptance for such activities began to disappear, and from the mid-1990s the "wild capitalism" began to "get civilized," and the goods which previously could be purchased only for foreign currency in special shops (e.g. Pewex, Baltona) and which were often the object of Poles' dreams (the electronic equipment of well-known producers, original Western clothes, such as jeans, shirts, denim jackets) became easily available in ordinary stores.

In her book, Drenda adopts the ethnomethodological approach, using the evidence of material culture and supplementing it with references to the recollections of culture users. Posters, photos, films, documentaries, TV programmes, commercials, popular books, newspaper articles of the era are the testimonies of the market changes that were taking place during this difficult period. What is important for today's researcher, these testimonies of culture are also perceived as the sites of haunting. Drenda successfully shows that despite the fact that Poland was not a friendly place to live at that time, it looks stylish and appealing in the nostalgic memories of people, films and articles in the press from today's perspective. Captured on the photographic films of the East German company ORWO, the pictures depicting this period are saturated with special colours, creating a unique and completely "unreachable" world.

3.

The range of topics discussed by Drenda in the book is broad, although — obviously — she does not claim to present a complete picture of the declining state regime. The list of topics missing from the book, but important in my opinion, embraces: the counter-cultural content of popular music, music videos as a form of registering selected aspects of reality and reflecting their changes, the transformations of youth subcultures (e.g. Depeche Mode fans, grunge, and The Cure fans), or Poles' fascination with television and its products: TV quiz shows (Blind date, Wheel of Fortune) and TV series of domestic (e.g. Alternatywy 4, Zmiennicy, W labiryncie) and foreign production (e.g. In the Stone Circle, Allo, Allo!, Dallas and Dynasty). This last aspect is mentioned in the book but should be given more space. A separate chapter could be devoted to the media addressed to children: TV programmes, magazines and journals. This was a unique cultural space in which Miś Uszatek (the children's TV series produced during the communist times) was suddenly replaced by Disney studio's Duck Tales (and later by Pokemon), and Świerszczyk (a children's magazine) was succeeded by Donald Duck, so that the Polish native patterns and values were being substituted by globalizing culture trends adopted mainly from the USA. 
Despite its merits, Drenda's book might leave a reader with more academic interests somewhat unsatisfied. The tradition of local knowledge, used after Clifford Geertz (the ethnography of everyday life and meanings, which real users of culture attribute to the studied phenomena in a given place and time), is confronted in Drenda's book with ethnomethodological research concerning cultural practices of Poles during the analyzed period. Thus, it would be worth showing this theoretical approach also in the context of gaining soft data (after all, "memory studies" as a form of biographical method and content analysis is based on such a methodological approach), as it has a meaningful impact on the research area the author deals with. Hence, the necessity of employing such sociological, cultural, and anthropological categories as the clash of cultures, the assimilation of values and patterns of behaviour, acculturation/counter-acculturation, cultural distance, or culture shock, which are absent in the volume. I believe that the whole argument would benefit from such anthropological categories, without losing its clarity.

4.

The book by Olga Drenda represents a larger cultural tendency of interest in the end of the period of socialist Poland and the transition to capitalism and democracy, which includes publications by historians, popular-science books, documentaries, computer and traditional games (board and strategic ones) and a whole range of everyday objects and clothes based on "straight from the Polish People's Republic" design. Naturally, in the phenomenon labelled as the "PRL cult" the internet environment plays the most important role: the memories of that time are present in the Polish internet discourse on the websites, entries on forums, blogs/photoblogs containing film videos, photographs and music video clips from the era. Polish hauntology is a way of remembering, expressed in the mythologization of the past, which cannot be assessed unambiguously, but is recalled with nostalgia, often without reflection over the nature of the cultural phenomena it refers to. In such a discourse, however, it is not the balanced assessment that comes out as a result of cultural analysis: the end of the socialist system and the period of political transformation still induce emotions and evoke memories. Olga Drenda's book is a valuable voice in the discussion on this phenomenon, as it captures a part of these responses. It shows in a successful, though perhaps incomplete way, that events, people, places and objects stored in old photographs and memories may create a unique cultural experience.

\section{References}

Couldry, N. (2000). Inside culture: Re-imagining the method of Cultural Studies. London, UK: Sage Publications.

Derrida, J. (2006). Specters of Marx: The state of the debt, the work of mourning and the new international. New York, NY: Routledge. 
Derrida, J. (2008). Marx and sons. In M. Sprinker (Ed.), Ghostly demarcations: A symposium on Jacques Derrida's Spectres of Marx (pp. 213-269). London, UK: Verso.

Davis, C. (2005). État Présent: Hauntology, spectres and phantoms. French Studies, 59(3), 373-379.

Davis, C. (2007). Haunted subjects: Deconstruction, psychoanalysis and the return of the dead. Basingstoke, UK: Palgrave Macmillan.

Jameson, F. (2008). Marx's purloined letter. In M. Sprinker (Ed.), Ghostly demarcations: A symposium on Jacques Derrida's Spectres of Marx (pp. 26-67). London, UK: Verso.

Pilar Blanco, M., \& Peeren, E. (Eds). (2013). The spectralities reader: Ghosts and haunting in contemporary cultural theory. London, UK: Bloomsbury.

Reynolds, S. (2011). Retromania: Pop culture's addiction to its own past. New York, NY: Faber \& Faber.

Royle, N. (2003). The uncanny. Manchester, UK: Manchester University Press. 


(1)

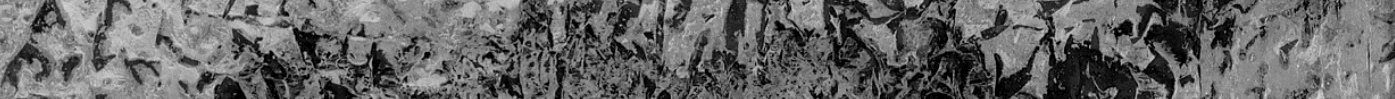

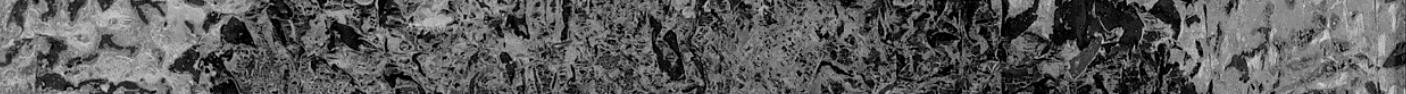
4.

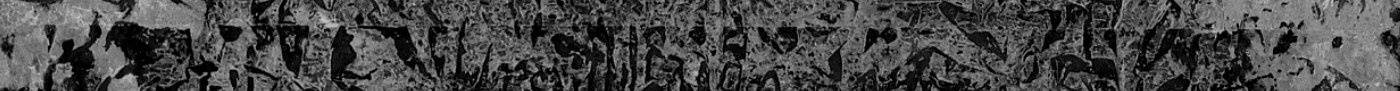

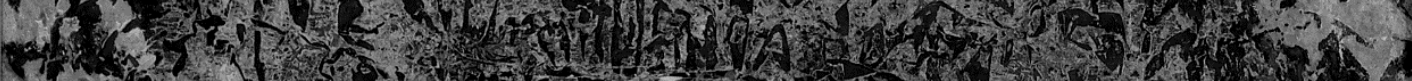

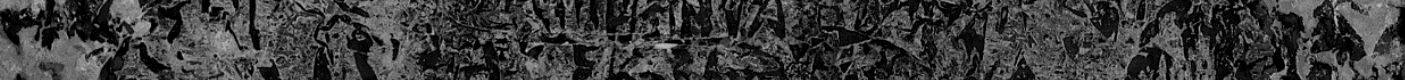

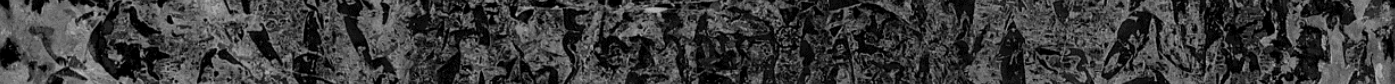
I.

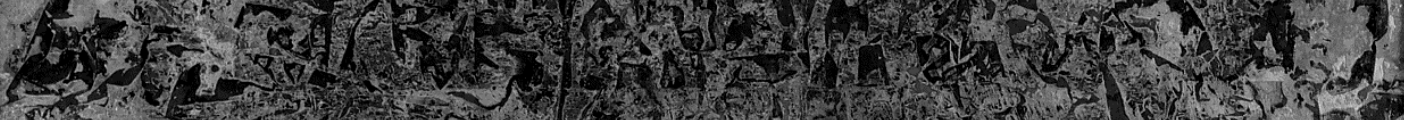

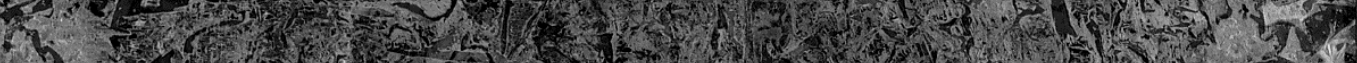

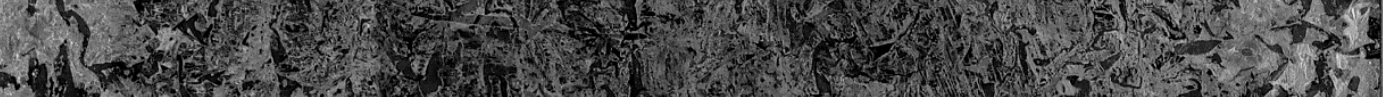

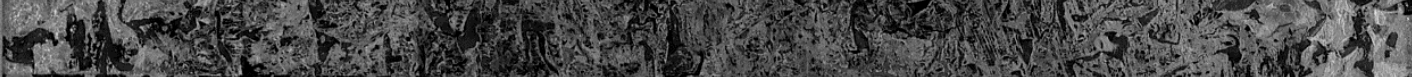

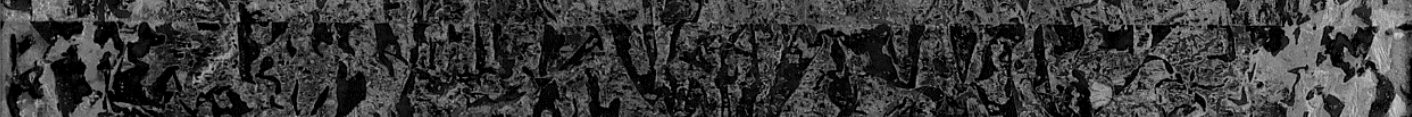

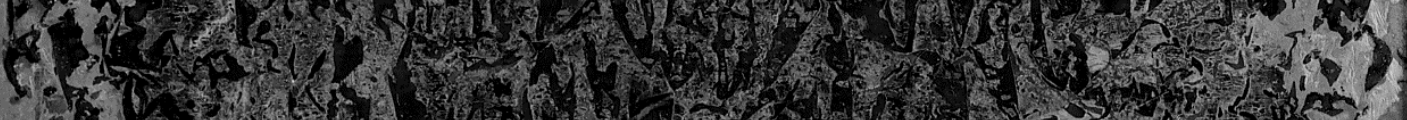

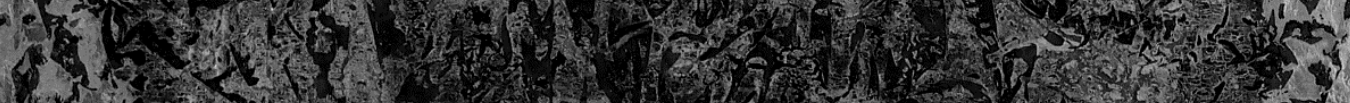

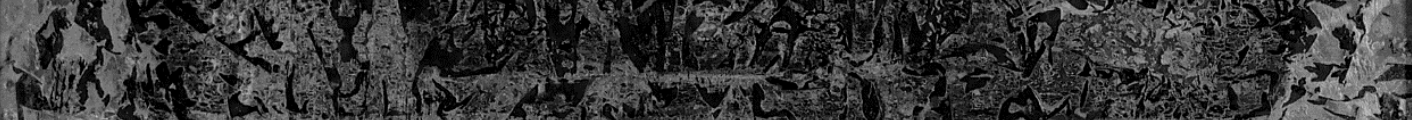

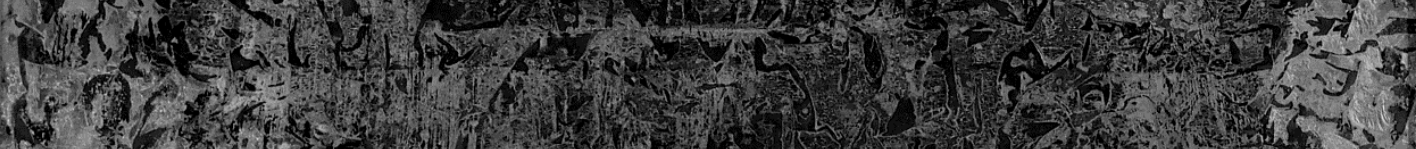

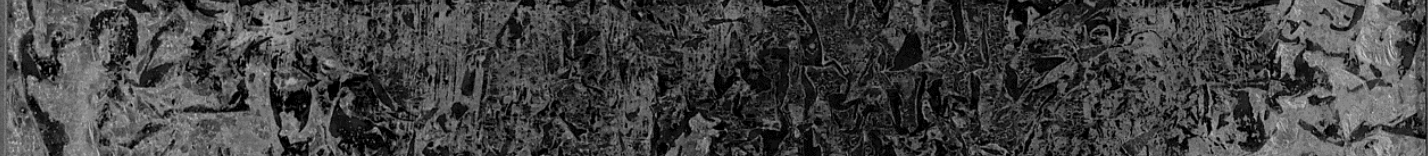

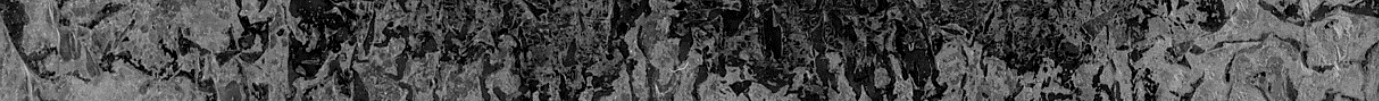

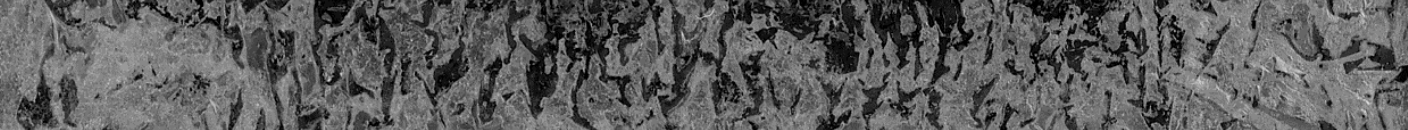

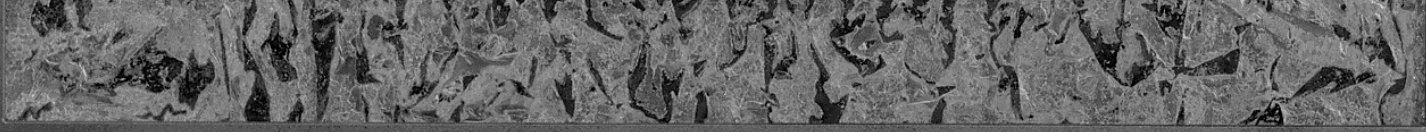


Anna Kola, Square I, steel, fused glass, aluminum foil, 67x67 cm, 2009 


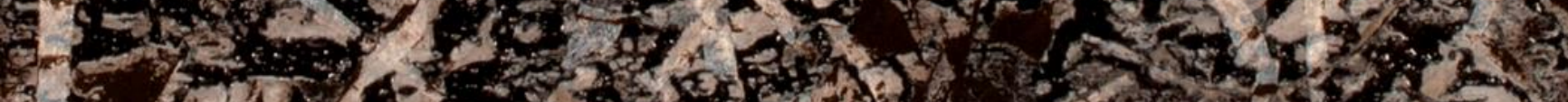

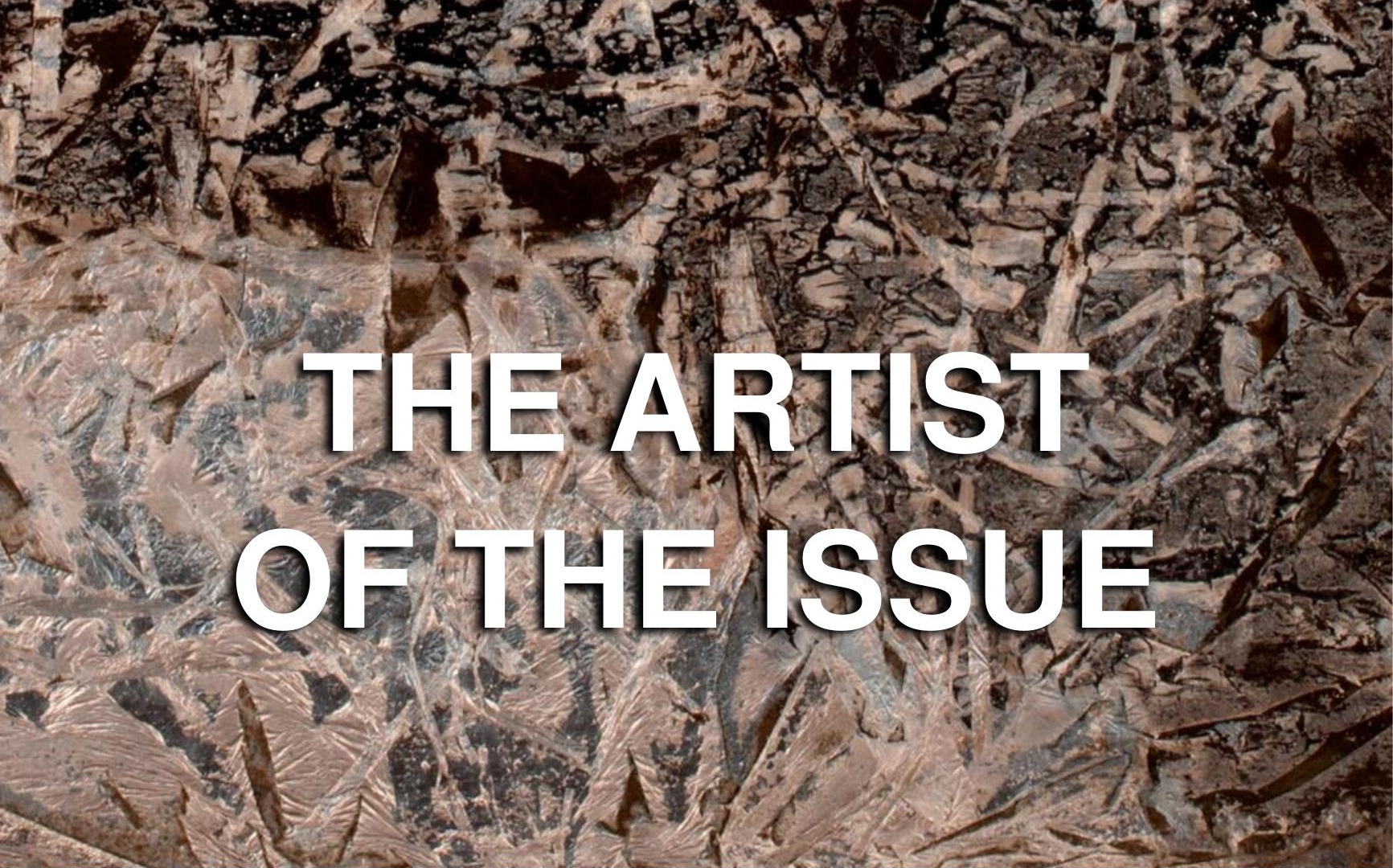


Anna Kola, $\boldsymbol{K}-\boldsymbol{I I I}$, steel, fused glass, aluminum foil, 50x50 cm, 2009 (fragment) 


\title{
Anna Kola:
}

About the Artist

\begin{abstract}
Anna Kola graduated from the Faculty of Fine Arts at Nicolaus Copernicus University in Torun in 1997. Her diploma project was realized in the Studio of Graphic Design and was awarded Tymon Niesiołowski's Medal. Since that time she has worked in the Section of Intermedia Arts at NCU, currently as an assistant professor, teaching in the Studio of Photography and in the Interdisciplinary Studio. She is a member of the Association of Polish Artists and Designers and the Association of Polish Art Photographers. Anna Kola presented her works at 19 solo exhibitions and more than 100 group exhibitions in Poland and abroad. She has received several awards and distinctions. She works with photography, graphic arts (traditional and digital), stained glass, art glass, and intermedia. Searching for the most effective means of expression, she combines different techniques and media, glass and photography being her favourite.

I use a variety of tools in order to show how I perceive and experience the world. I do not evaluate or compare them, because each of them is different. When we talk about something we use different words, yet we can communicate the same content in many ways. My greatest inspiration is the world around me-nature and people. I look at and contemplate the images that surround me and then I try to reproduce them, choosing various techniques to achieve this aim. I work with art glass, stained glass and graphic arts, but my primary field is photography, which is often the starting point for the works realized in a different medium - I use photography in graphic art or combine it with glass. I feel a strong urge to use a variety of techniques and mixing them. Trying to materialize my reflections and emotions in a different medium, I hope that every time they will carry new meanings and evoke new emotional responses. (Anna Kola)
\end{abstract}

\section{Selected recent group exhibitions:}

2017-Gniazdo / Nest-Borders in Contemporary Polish Art, Polish Academy of Sciences-Scientific Centre in Vienna (Austria)

2017-1 $1^{\text {th }}$ International Textile Art Triennial, Musées d'Angers, Angers (France)

2017-Borders/ Cut Lines, Yermilov Centre, Kharkiv (Ukraine)

2016 - $9^{\text {th }}$ International Biennal of Miniature Art, "Gaude Mater" Centre of Culture Promotion, Częstochowa (Poland)

2015-New Glass Review 36, Corning Museum of Glass, Corning, NY (USA) 
2015 - $4^{\text {th }}$ Bangkok Triennale International Print and Drawing Exhibition, Bangkok Art and Culture Centre, Bangkok (Thailand)

$2014-4^{\text {th }}$ International Biennial of Graphic Digital Arts, New Gallery, Design Centre, Gdynia (Poland)

2014- $3^{\text {rd }}$ Guangzhou International Exlibris and Mini-Prints Biennial, Art Museum of Guangzhou Academy of Fine Arts, Guangzhou (China)

$2013-10^{\text {th }}$ National Exhibition of Weaving Miniatures, Central Museum of Textiles, Łódź (Poland)

2012 - $7^{\text {th }}$ International Triennial of Graphic Art Bitola, National Institute and Museum, Bitola (Macedonia)

$2011-10^{\text {th }}$ Quadrennial of Polish Woodcut and Linocut, BWA Art Gallery, Olsztyn (Poland)

2011-Miniprint Annual 2011, Lessedra Art Gallery, Sofia (Bulgaria)

2011-14 $4^{\text {th }}$ International Triennial of Small Graphic Forms, City Art Gallery, Lódź (Poland)

The following works by Anna Kola are used in this issue of AVANT:

from the series Glassy / V , fused glass, steel, 109x75 cm, 2005 (front cover)

$\boldsymbol{K}-\boldsymbol{I}$, steel, fused glass, aluminum foil, $50 \times 50 \mathrm{~cm}, 2009$ (pp. 13 \& 27)

Remains III, digital print, 11x16 cm, 2011 (p. 25)

from the series Landscapes / T-IV, fused glass, 50x80 cm, 2010 (p. 63)

from the series Landscapes / T-V, fused glass, 50x80 cm, 2010 (p. 65)

from the series Plants, mixed media (toned photograph, resin), 100x70 cm, 2007 (p. 115)

from the series Plants, mixed media (toned photograph, resin), 100x70 cm, 2007 (p. 117)

Untitled, digital print, 49x100 cm, 2010 (p. 167)

Hand $\boldsymbol{I I I}>\boldsymbol{I} \boldsymbol{V}$, photograph, $35 \times 100 \mathrm{~cm}, 2007$ (p. 167)

Hand $\boldsymbol{V}>\boldsymbol{V I}$, photograph, $35 \times 100 \mathrm{~cm}, 2007$ (p. 167)

Untitled, glass, transfer paper, 59x41 cm, 2010 (p. 211)

$\boldsymbol{K}-\boldsymbol{I I I}$, steel, fused glass, aluminum foil, $50 \times 50 \mathrm{~cm}, 2009$ (pp. 213 \& 239)

Square I, steel, fused glass, aluminum foil, $67 \times 67$ cm, 2009 (p. 237) 


\section{Contributors to this Issue}

Tymon Adamczewski is Assistant Professor at the English Department of Kazimierz Wielki University, Bydgoszcz, Poland. He is the author of Following the Textual Revolution: The Standardization of Radical Critical Theories of the 1960s (McFarland 2016) and articles on aspects of contemporary critical discourses and literary and cultural studies.

Anna Branach-Kallas (Ph.D., D.Litt.) is Associate Professor in the Department of English at Nicolaus Copernicus University, Torun, Poland. She is the author of Uraz przetrwania. Trauma i polemika z mitem pierwszej wojny światowej w powieści kanadyjskiej [The Trauma of Survival: The (De)Construction of the Myth of the Great War in the Canadian Novel] (2014), which was awarded a Pierre Savard Award by the International Council for Canadian Studies. She has also published Corporeal Itineraries: Body, Nation, Diaspora in Selected Canadian Fiction (2010), In the Whirlpool of the Past: Memory, Intertextuality and History in the Fiction of Jane Urquhart (2003) and over sixty essays. Currently, she is director of a comparative project devoted to the analysis of representations of the Great War in contemporary Great War fiction in England, France and Canada.

Mirosława Buchholtz is Professor of English and Director of the English Department at Nicolaus Copernicus University in Toruń, where she teaches American and Canadian literature, film adaptations of literature and biography, life writing, and postcolonial studies. A graduate of the Jagiellonian University (Poland) and Brandeis University (USA), she has published some sixty articles, six books, sixteen edited volumes, four edited issues of academic journals, numerous reviews and translations. She is former President of the Henry James Society (2017) and a member of the Polish Accreditation Committee (quality assurance agency), since 2012.

Marek Jeziński is Professor of Communication Studies and Head of Journalism and Social Communication Department at Nicolaus Copernicus University in Torun. His main academic interests include social anthropology, political sociology, mass media, and contemporary popular culture. He is the author of 6 books and over 100 academic papers on political science, sociology, popular culture, contemporary theatre and music. He edited and co-edited several books and is the editor-in-chief of the academic journal Nowe Media (New Media). 
Anne Keithline is an independent scholar from the United States. Her primary research interest is Joseph Conrad, with a special interest in the history of Conrad Studies in Poland and, currently, Conrad's ghosts. A graduate of the University of Massachusetts (Lowell), for the past four years she has headed a New England-based tour company whose mission is to preserve and propagate regional history and ghost lore. Anne is a regular contributor of book reviews and other materials to the American Conrad Society's Joseph Conrad Today.

Aleksandra Kędzierska is Associate Professor of English Literature at the Maria CurieSkłodowska University, Lublin, Poland. She has written extensively on committed, religious and political, poetry, as well as Victorian and modern British Literature. She has written Isaac Rosenberg and Wilfred Owen: A Study in the Poetry of World War I (1995), On the Wings of Faith: A Study of the Man-God Relationship in the Poetry of Gerard Manley Hopkins (2001), and many critical essays on committed poetry as well as works by Oscar Wilde and Charles Dickens.

Anna Kisiel is a PhD student in Literary Studies in the Department of Literary and Cultural Theory, Institute of English Cultures and Literatures, at the University of Silesia in Katowice. Her academic research revolves around - but is not limited to - matrixial psychoanalysis, trauma studies, photography theory, and body and femininity in visual arts and poetry. Currently she is working on her $\mathrm{PhD}$ project concerning the notion of the body in Bracha L. Ettinger's theory and art. She is an active member of the Gender Studies Centre, University of Silesia in Katowice.

Barbara Klonowska is Assistant Professor in the Institute of English at the Catholic University of Lublin, Poland. She teaches British literature and culture and has published on contemporary British fiction and film; her book-length studies include Contaminations: Magic Realism in Contemporary British Fiction (2006), and Longing for Romance: British Historical Romances 1990-2010 (2014). Her academic interests include contemporary literature, literary theory, magic realism in fiction and film, and cinematographic utopias and dystopias.

Michal Krzykawski is Assistant Professor at the Institute of Romance Languages and Translation Studies of the University of Silesia in Katowice. He is the author of L'effetBataille. De la littérature d'excès à l'écriture. Un texte-lecture (Katowice, 2011) and many articles on contemporary French thought (Bataille, Derrida, Blanchot, Nancy, Bailly, but also Agamben). He is currently working on friendship and community (research grant awarded by the Polish National Science Center (NCN)) and animals in contemporary French thought. His new book (in Polish), The Other, the Common: Thirty-Five Years of French Philosophy has just been published. 
Edyta Lorek-Jezińska (D. Litt.) teaches British drama, theatre, gender and cultural studies in the Department of English at Nicolaus Copernicus University in Torun, Poland. She is the author of The Hybrid in the Limen: British and Polish Environment-Oriented Theatre (2003, Toruń) and Hauntology and Intertextuality in Contemporary British Drama by Women Playwrights (2013, Toruń). She has co-edited several volumes, including Spectrality and Cognition: Haunted Cultures, Ghostly Communications of Theoria et Historia Scientiarum (co-edited with Katarzyna Więckowska) (2017).

Jacek Mydla is Assistant Professor at the Institute of English Cultures and Literatures, University of Silesia, Poland. He holds an MA in philosophy (the Catholic University of Lublin) and in English (the University of Silesia), as well as a PhD and a post-doctoral degree in literary studies. He conducts research and lectures in the history of British literature, specifically Gothic fiction and drama, and theory of narrative. His book-length publications are: The Dramatic Potential of Time in Shakespeare (2002), Spectres of Shakespeare (2009), and The Shakespearean Tide (2012). Forthcoming is a book on the ghost stories of M. R. James.

Agnieszka Pantuchowicz is Assistant Professor at the SWPS University of Social Sciences and Humanities in Warsaw, Poland, where she teaches translation and literary studies. Her research interests are translation theory and cultural studies, comparative literature, and feminist criticism.

Pawel Pyrka is a lecturer at the SWPS University of Social Sciences and Humanities in Warsaw, teaching courses in American literature, cultural theory, and English. He holds a Master's Degree in English and a PhD in cultural studies. His interests include American fiction, popular culture and media studies.

Tadeusz Rachwal is Professor of English at the SWPS University of Humanities and Social Sciences in Warsaw. His books, essays and academic papers address various issues of colonial and postcolonial studies, contemporary literary and critical theory, sociology of literature and anthropology. His most recent publication is a monographic study of the ideas of property and loss and their aesthetic, ethical and philosophical significances in contemporary theoretical approaches to projects of social and political change (Precarity and Loss. On Certain and Uncertain Properties of Life and Work, Springer-Verlag: 2017). 
Arthur Redding is Professor of English at York University in Toronto, Canada. He is the author of several books: Raids on Human Consciousness: Writing, Anarchism, and Violence (South Carolina, 1998); Turncoats, Traitors, and Fellow Travelers: Culture and Politics of the Early Cold War (Mississippi, 2008); "Haints": American Ghosts, Millennial Passions, and Contemporary Gothic Fiction (Alabama, 2011) and, most recently, Radical Legacies: Twentieth Century Public Intellectuals in the United States (Rowman \& Littlefield, 2015).

Juan Evaristo Valls Boix is a PhD student in Contemporary Philosophy at the University of Barcelona, where he is completing a thesis about Søren Kierkegaard and Jacques Derrida. He studied Philosophy in Valencia and Paris, as well as Theory of Literature in Barcelona. He has been guest researcher in the Hong Kierkegaard Library (St. Olaf College), the Kierkegaard Forskningscenter (Copenhagen), and the Faculté d'arts et lettres at Université Catholique de Louvain. His chief interests are philosophy of literature, philosophy of religion, and theory of subjectivity, with special attention to deconstruction and contemporary French thought. He is member of the "Càtedra de Filosofía contemporània" research team.

Katarzyna Więckowska is Assistant Professor at the Department of English, Nicolaus Copernicus University, Torun, where she teaches cultural and literary studies. She has published Spectres of Men (2014) and On Alterity (2008), and co-edited a number of volumes, including The Gothic (2012) and Spectrality and Cognition: Haunted Cultures, Ghostly Communications (2017; co-edited with Edyta Lorek-Jezińska). Her research interests include contemporary British and American fiction, literary and cultural theory, feminist criticism, and hauntology. 

This issue of AVANT is dedicated to hauntology, an approach originally defined by Jacques Derrida in his Spectres de Marx (1993). Hauntology has been used to describe and problematize the indeterminacy and interconnectedness of texts, the endurance of memory and traumatic experiences in the present time, the validity and persistence of the past, the uncertainty and non-finality of death, as well as mourning practices. It has contributed to the discussion of the identity and legitimacy of various Others, their suppressed representations and haunting absences, and our responsibility for preserving them. Hauntology has made it possible to consider the demands of the dispossessed, investigate various manifestations of the uncanny as well as conceptualize the transformation and redefinition of mediated and technological selves. The studies collected in Haunted Cultures / Haunting Cultures address all of these questions, highlighting various ways in which hauntology can be used to destabilize conventional divisions, redefine established analytical tools, and question the accepted procedures of reading cultural texts and practices. 